Daniela Cajado de Oliveira Souza Carvalho

Purificação e caracterização de peptidases presentes no veneno do escorpião Tityus serrulatus

Tese apresentada ao Programa de Pós-Graduação Interunidades em Biotecnologia USP/ Instituto Butantan/IPT, para obtenção do Título de Doutor em Biotecnologia.

São Paulo 
Daniela Cajado de Oliveira Souza Carvalho

Purificação e caracterização de peptidases presentes no veneno do escorpião Tityus serrulatus

Tese apresentada ao Programa de PósGraduação Interunidades em Biotecnologia USP/ Instituto Butantan/IPT, para obtenção do Título de Doutor em Biotecnologia.

Orientadora: Dra. Fernanda Calheta Vieira Portaro

Versão corrigida. A versão original eletrônia, encontra-se disponível tanto na Biblioteca do ICB quanto na Biblioteca Digital de Teses e Dissertações da USP (BDTD).

\section{São Paulo}


CATALOGAÇÃO NA PUBLICAÇÃO (CIP)

Serviço de Biblioteca e informação Biomédica

do Instituto de Ciências Biomédicas da Universidade de São Paulo

Ficha Catalográfica elaborada pelo(a) autor(a)

Carvalho, Daniela Cajado de Oliveira Souza

Purificaçäo e caracterizaçĩo de peptidanea

presentes no veneno do eacorpiäo Tityus merrulatus

7 Daniela Cajado de Oliveira Souza Carvalho;

orientador Fernanda Calheta Vieira Portaro. -- Såo

Paulo, 2017

$140 \mathrm{P}$.

Teme (Doutorado)) -- Univeraidade de Săo Paulo, Inatituto de Ciencias Biomedicas.

1. Eacorpião amarelo. 2. Veneno. 3. Purificação. 4. Peptidamea . 5. Peptideon bioativon. I. Portaro, Fernanda Calheta Vieira, orientador. II. Titulo. 
Universidade de São Paulo

ATA DE DEFESA

Aluno: 87131 - 8725434 - 1 / Página 1 de 1

Ata de defesa pública de Tese do(a) Senhor(a) Daniela Cajado de Oliveira Souza Carvalho no Programa: Biotecnologia, do(a) Interunidades em Biotecnologia da Universidade de São Paulo.

Aos 21 dias do mês de setembro de 2017, no(a) ICB IV, realizou-se a Defesa da Tese do(a) Senhor(a) Daniela Cajado de Oliveira Souza Carvalho, apresentada para a obtenção do título de Doutora intitulada:

"Purificação e caracterização de peptidases presentes no veneno do escorpião Tityus serrulatus"

Após declarada aberta a sessão, o(a) Sr(a) Presidente passa a palavra ao candidato para exposição e a seguir aos examinadores para as devidas arguições que se desenvolvem nos termos regimentais. Em seguida, a Comissão Julgadora proclama o resultado:

\begin{tabular}{|c|c|c|c|}
\hline Nome dos Participantes da Banca & Função & Sigla da CPG & Resultado \\
\hline Fernanda Calheta Vieira Portaro & Presidente & I. Butantan & APROVADA \\
\hline Ivo Lebrun & Titular & IB - Externo & APRAVADA \\
\hline Geraldo Santana Magalhães & Titular & IB - Externo & APROVADA \\
\hline Vitor Marcelo Silveira Bueno Brandão de Oliveira & Titular & UNIFESP - Externo & APROUADA \\
\hline Adriana Karaoglanovic Carmona & Suplente & UNIFESP - Externo & APROVAOA \\
\hline
\end{tabular}

Resultado Final: APROVADA

\section{Parecer da Comissão Julgadora *}

Eu, Jabia Reis Nilorvora , lavrei a presente ata, que assino juntamente com os(as) Senhores(as). São Paulo, aos 21 dias do mês de setembro de 2017.

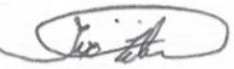

Ivo Lebrun

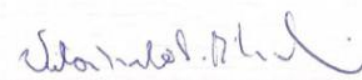

Vitor Marcelo Silveira Bueno Brandão de Oliveifa

Lencukgo Vus Pla

Feynanda Calheta Vieira Portaro

Presidente da Comissão Julgadora

* Obs: Se o candidato for reprovado por algum dos membros, o preenchimento do parecer é obrigatório.

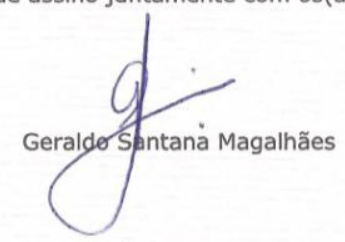

$4 \&$ inume

Adriana Karaoglanovic Carmona

A defesa foi homologada pela Comissão de Pós-Graduação em $02 \cdot 10 \cdot 17$ e, portanto, o(a) aluno(a) faz jus ao título de Doutora em Ciências obtido no Programa Biotecnologia.

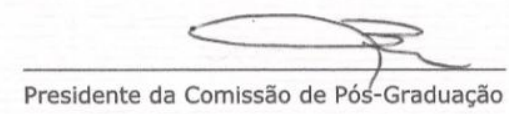




\section{CERTIFICADO}

Certificamos que o projeto intitulado "Purificação e caracterização de peptidases presentes no veneno do escorpião Tityus serrulatus", protocolo $n^{\circ}$ 1162/13, sob a responsabilidade de Fernanda Calheta Vieira Portaro e Daniela Cajado de Oliveira Souza Carvalho - que envolve a criação e/ ou utilização de animais pertencentes ao filo Chordata, subfilo Vertebrata (exceto o homem), para fins de pesquisa científica - está de acordo com os preceitos da Lei $\mathrm{n}^{\circ} 11.794$, de 8 de outubro de 2008, do Decreto 6.899, de 15 de julho de 2009 e de normas complementares, bem como está de acordo com os Princípios Éticos na Experimentação Animal adotado pelo Colégio Brasileiro de Experimentação Animal (COBEA), e foi aprovado pela COMISSÃO DE ÉTICA NO USO DE ANIMAIS DO INSTITUTO BUTANTAN (CEUAIB) em reunião de 11/12/2013.

This is to certify that the proposal "Purification and characterization of peptides present in the venom of Tityus serrulatus scorpion", protocol $n^{0} 1162 / 13$, under the responsibility of Fernanda Calheta Vieira Portaro and Daniela Cajado de Oliveira Souza Carvalho, - which involves the breeding and/or use of animals belonging to phylum Chordata, subphylum Vertebrata (except human beings) - has been reviewed by the Institute Butantan Animal Care and Use Committee and approved in 12/11/2013. This proposal is in accordance with standards outlined by Brazilian laws for use of experimental animals, and with ethical principles adopted by the Brazilian College of Animal Experimentation.

\begin{tabular}{|c|c|}
\hline $\begin{array}{c}\text { Vigência do Projeto: } \\
12 / 2014-06 / 2015\end{array}$ & $\mathbf{N}^{\circ}$ de animais/espécie \\
\hline Laboratório de Imunoquímica & 48 ratos Wistar 230-250 (M) \\
\cline { 2 - 2 }
\end{tabular}

São Paulo, 12 de dezembro de 2013

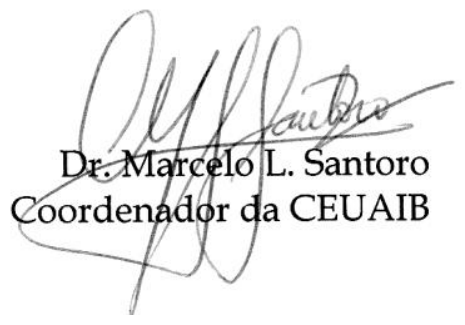




\section{Agradecimentos}

À minha orientadora Dra. Fernanda Calheta Vieira Portaro por todo carinho e dedicação durante todos esses anos. Sei que muitas vezes te deixei de "cabelo em pé" por conta da minha ansiedade, mas acho que podemos dizer que aprendemos e conquistamos muitas coisas juntas.

Ao Laboratório de Imunoquímica do Instituto Butantan e a Dra. Denise Vilarinho Tambourgi pela oportunidade de estágio e de aprimoramento profissional.

Aos meus queridos amigos Alexandre Kazuo Kuniyoshi, Bruno Duzzi, Cristiane Castilho Silva e Roberto Tadashi Kodama pela amizade, discussões científicas de séries e filmes, apoio científico em teorias de universos paralelos, risadas, hamburgeres, sorvetes\&gelatos, viagens de congresso e ajuda em grande parte dos experimentos realizados deste trabalho!.

Aos professores, pesquisadores, alunos e funcionários do laboratório, pelo trabalho exemplar e pela ajuda diária - em especial, ao Fábio Carlos Magnoli (Fabinho), pelas discussões sobre purificação; À Isa Villas Boas e À Pri Hess por toda ajuda durante esses anos.

À Dra. Úrsula Castro de Oliveira e ao Dr. Inácio Junqueira-de-Azevedo por disponibilizarem dados do transcriptoma do escorpião Tityus serrulatus, fornecendo assim dados essenciais para o trabalho.

À Dra. Ana Karina de Oliveira e sua orientadora Dra. Solange Serrano, que me auxiliaram nas análises iniciais de espectrometria de massas quanto as hidrólises dos peptídeos pela ação das proteases do veneno de Tityus serrulatus.

Ao Dr. Leo Kei Iwai e ao técnico Ismael Feitosa Lima do Laboratório de Toxinologia Aplicada pela colaboração com o Orbitrap.

Ao Thiago de Jesus Oliveira e a Soraia Maria do Nascimento, do Laboratório de Toxinologia Aplicada pelas fotos dos Tityus serrulatus e pela aula de extração de veneno de escorpião.

Aos meus alunos de PIBIC Junior Isa e Fer por me ensinarem um pouco como é ser uma orientadora e pela ajuda nos experimentos de caracterização das metalloserrulases.

À SBTx e à SBTx jovem - Alê, Andrea, Bruno, Juliana, Felipe - pela experiência de participar da comissão da SBTx jovem. Acredito que pudemos fazer uma diferença na nossa gestão!

À FAPESP, pela concessão da bolsa de doutorado (projeto 2013/15343-0) e o suporte financeiro que possibilitou a realização deste trabalho e da publicação dos artigos.

À minha família, em especial minha mãe, minha irmã e meu futuro-marido Thiago pelo grande apoio, por lerem quase todos meus textos e ouviram todas minhas apresentações orais várias e várias (e várias) vezes.

À Pós Graduação Interunidades em Biotecnologia por toda ajuda.

Aos meus amigos e a todos que de alguma forma colaboraram para a realização deste projeto.

E, finalmente, aos escorpiões amarelos que forneceram seus venenos, permitindo este estudo! 


\section{Agradecimento à agência de fomento}

Agradeço a Fundação de Amparo a Pesquisa do Estado de São Paulo (FAPESP) pela concessão da bolsa e por suporte financeiro do projeto de doutorado intitulado "Purificação e caracterização de peptidases presentes no veneno do escorpião Tityus serrulatus" (projeto 2013/15343-0), que possibilitou a realização deste trabalho e da publicação dos artigos. 
"The desire for knowledge shapes a man"

Patrick Rothfuss - The wise man's fear 
Resumo
CARVALHO, D. C. O. S. Purificação e caracterização de peptidases presentes no
veneno do escorpião Tityus serrulatus. 2017.140 f. Tese (Doutorado em Biotecnologia) - Instituto de Ciências Biomédicas, Universidade de São Paulo, São Paulo, 2017.

Acidentes causados por escorpião representam um problema relevante para a saúde pública no Brasil, sendo a principal espécie envolvida o escorpião Tityus serrulatus devido ao potencial do veneno para induzir quadros de envenenamento graves. $\mathrm{O}$ tratamento recomendado no caso de sintomas sistêmicos é o uso dos soros específicos (antiescorpiônico e antiaracnidico). Na composição deste veneno, as neurotoxinas são as moléculas mais estudadas e conhecidas. Em contraste, pouco se sabe sobre os componentes proteolíticos dos venenos de escorpiões e seus efeitos no envenenamento. Assim, este trabalho teve como objetivo estudar bioquimicamente as peptidases presentes no veneno e suas possíveis participações no envenenamento, além de avaliar o potencial neutralizante dos antivenenos produzidos pelo Instituto Butantan. Primeiramente, foi avaliada a hidrólise dos peptídeos biologicamente ativos bradicinina, angiotensina I, dinorfina 1-13 e peptídeos da família do neuropeptídeo Y pelo veneno total. Os pontos de clivagem dos substratos foram obtidos por espectrometria de massas, sendo observada concomitante participação de endo, amino e carboxipeptidases. A classe enzimática atuante nestes novos substratos foi verificada, bem como a neutralização pelos antivenenos, sendo observada a ação exclusiva de metalopeptidases que são parcialmente neutralizadas em doses moderadas de ambos os soros. Substratos fluorescentes foram utilizados, Abz-GFLRRV-EDDnp e Abz-FRK(Dnp)P-OH, e pelo uso de inibidores específicos foi notado que são alvos de diferentes proteases do veneno, endopeptidases e carboxipeptidases, respectivamente. Após essas caracterizações, etapas de purificação foram iniciadas com base no screening de atividades relevantes observadas no veneno total. Na primeira etapa, troca aniônica, diferentes atividades sobre os substratos naturais foram observadas principalmente em 3 frações, as quais foram posteriormente fracionadas por gel-filtração. Para duas diferentes frações provenientes da etapa de gel-filtração, membranas de corte molecular de $30 \mathrm{kDa}$ foram utilizadas como refinamento, obtendo a purificação de duas endopeptidases. Para a purificação da carboxipeptidase com atividade similar a ACE, foi necessária uma etapa cromatográfica adicional em uma coluna de troca catiônica, resultando na amostra homogênea. As três bandas do gel relativas as peptidases purificadas foram submetidas à análise por espectrometria de massas e os resultados indicaram a purificação das metallosserrulases 3 e 4 e para a carboxipeptidase, com auxílio de sequências do transcriptoma de T. serrulatus, foi identificada uma ACE-like. A formação de angiotensina II e a inativação da bradicinina in vitro pela ACE-like purificada pode indicar um possível envolvimento desta peptidase no quadro de hipertensão, comumente apresentado pelas vítimas. Os peptídeos da família do neuropeptídeo Y e a dinorfina 1-13, que haviam sido caracterizados inicialmente como substratos para o veneno total, também foram hidrolisados pelas metalloserrulases purificadas, podendo indicar a contribuição destas peptidases nos efeitos neurotóxicos, também presentes nos acidentados. Os pontos de clivagens foram determinados, permitindo o estudo da especificidade primária das duas endopeptidases. Além disso, as condições ótimas de trabalho foram determinadas para todas as peptidases purificadas. Por fim, este trabalho fornece informações importantes sobre três proteases do veneno de $T$. serrulatus, bem como seus possíveis papéis nos sintomas de envenenamento por este escorpião.

Palavras-chave: Tityus serrulatus. Escorpião. Proteases. Metalloserrulases. ACElike.Antivenenos. 


\begin{abstract}
CARVALHO, D. C. O. S. Purification and characterization of peptidases from the venom of Tityus serrulatus scorpion. 2017. 140 p. Doctorate thesis (Biotechnology) Instituto de Ciências Biomédicas, Universidade de São Paulo, São Paulo, 2017.
\end{abstract}

Accidents caused by scorpions are a relevant health problem in Brazil, with the Tityus serrulatus scorpion as the main species associated to it, as severe envenomations are possible. The recommended treatment for systemic symptoms is the use of specific antivenom (antiscorpion and antiarachnid). In the composition of the venom, neurotoxins are the most studied and, in contrast, little is known about the proteolytic components of scorpion venoms and their effects on envenomation. Thus, the objective of this work was to biochemically study the peptidases present in the venom and their possible role in the envenomation, as well as to evaluate the neutralizing efficacy of the antivenoms produced by the Butantan Institute. First, hydrolysis of the biologically active peptides bradykinin, angiotensin I, dynorphin 1-13 and peptides of the neuropeptide Y family by crude venom was evaluated. The cleavage points of the substrates were obtained by mass spectrometry, indicating concomitant participation of endo, amino and carboxypeptidases. The enzymatic class acting on these new substrates was tested, as well as its neutralization by the antivenoms, and the exclusive action of metalopeptidases which are partially neutralized in moderate doses of both sera were observed. Fluorescent substrates, Abz-GFLRRV-EDDnp and Abz-FRK(Dnp)P-OH, were used, and by the action of specific inhibitors it was noted that they are targets of different venom proteases, endopeptidases and carboxypeptidases, respectively. After these characterizations, purification steps were started based on the screening of relevant activities observed in the crude venom. Firstly, the anion exchange led to 3 different fractions of interest, which were later fractionated by gel filtration. For two different fractions obtained from the gel filtration step, $30 \mathrm{kDa}$ molecular cut off membranes were used, and the purification of two endopeptidases were obtained. A new step, using a cation exchange column, was performed for the purification of carboxypeptidase with ACE-like activity, resulting in a uniform sample. The three gel bands corresponding to the purified peptidases were submitted to mass spectrometry analysis and the results indicated the purification of the metalloserrulases 3, 4 and the carboxypeptidase. The formation of angiotensin II and the in vitro inactivation of bradykinin by the purified ACE-like may indicate a possible involvement of this peptidase on the victims' hypertension. The neuropeptide $\mathrm{Y}$ family peptides and dynorphin 1-13 - previously characterized as substrates for the crude venom - were also hydrolyzed by the purified metalloserrulases, and this could indicate the contribution of these peptidases to the neurotoxic effects on envenomation victims. The cleavage points were determined, allowing for the study of the primary specificity of the two endopeptidases. In addition, optimal working conditions were determined for all purified peptidases. Finally, this work provides important information on three proteases of $T$. serrulatus venom, as well as their possible roles in the envenomation symptoms.

Keywords: Tityus serrulatus. Scorpion. Peptidases. Metalloserrulases. ACElike.Antivenoms. 


\section{Lista de Tabelas}

Tabela 01 - Seleção de novos substratos para o veneno de Tityus serrulatus em tampão 1 e tampão 2

Tabela 02 - Determinação dos produtos de hidrólise dos novos substratos do veneno total de $T$. serrulatus.

Tabela 03 - Determinação dos produtos de clivagem da angiotensina I e bradicinina hidrolisadas pelo veneno de $T$. serrulatus.

Tabela 04 - Inibição das peptidases do veneno de Tityus serrulatus na hidrólise de peptídeos biologicamente ativos utilizando os inibidores captopril e EDTA.....

Tabela 05 - Atividade específica do veneno total de Tityus serrulatus e das frações coletadas da troca aniônica sobre a hidrólise de hemopressina e AbzFRK(Dnp)P-OH.

Tabela 06 - Comparativo de identidade e similaridade de estrutura primária dos transcritos de ACEs do veneno de T. serrulatus, $T$. bahiensis, e $T$. obscurus e da ACE testicular humana.

Tabela 07 - Atividade específica do veneno de Tityus serrulatus e das frações coletadas da troca aniônica na hidrólise de dinorfina 1-13 fluorescente AbzGFLRRV-EDDnp.

Tabela 08 - Pontos de clivagem do neuropeptídeo Y, peptídeo YY e polipeptídeo pancreático pela hidrólise das metalloserrulases 3 e 4

Tabela 09 - Determinação das constantes cinéticas da metalloserrulase 4 purificada em $\mathrm{pH}$ ideal.

Tabela 10 - Comparativos de inibição entre o veneno total de Tityus serrulatus, metalloserrulase 3 e metalloserrulase 4 frente ao soro antiescorpiônico e soro antiaracnídico. 


\section{Lista de Figuras}

Figura 01 - Escorpião amarelo, evidenciando o tamanho, as serrilhas e a 21 coloração.

Figura 02 - Tempo de atendimento versus letalidade de acidentes por 24 escorpiões.

Figura 03 - Esquema representando as etapas de purificação e os screenings de 37 atividade utilizados no presente trabalho.

Figura 04 - Ensaio de atividade do veneno de Tityus serrulatus sobre os substratos Abz-GFLRRV-EDDnp e Abz-FRK(Dnp)P-OH à direita).

Figura 05 - Inibição das atividades do VTs sobre os substratos fluorescentes para carboxi e endopeptidases

Figura 06 - Análise de hidrólise da hemopressina pelo VTs em cromatografia de fase 54 reversa e inibição por captopril.

Figura 07 - Efeito da concentração de íons cloreto sobre Enzima Conversora de 55 Angiotensina I e veneno de Tityus serrulatus.

Figura 08 - Curva de inibição por neutralização com antivenenos comerciais 56 utilizando o substrato Abz-GFLRRV-EDDnp e $\mathrm{o}$ veneno de $T$. serrulatus)....

Figura 09 - Curva de neutralização com antivenenos comerciais utilizando o substrato Abz-FRK(Dnp)P-OH e o veneno de T. serrulatus.

Figura 10 - Neutralização de peptidases do veneno de Tityus serrulatus por 58 antivenenos comerciais utilizando como substratos peptídeos biologicamente ativos

Figura 11 - Perfil cromatográfico do veneno total de $T$. serrulatus utilizando a coluna de troca aniônica.

Figura 12 - Ação peptidásica da fração F1 em Angiotensina I (incubação overnight) e 61 Hemopressina.

Figura 13 - Gel SDS-PAGE de poliacrilamida a 13\% com coloração Coomassie Blue Coloidal do veneno total de T. serrulatus (VTs) e da fração F1 proveniente da cromatografia de troca iônica.

Figura 14 - Perfil cromatográfico da fração F1 em gel-filtração

Figura 15 - Resultados das subsfrações de F1 obtidas em gel-filtração.

Figura 16 - Cromatografia de troca catiônica da fração F1-2. 
Figura 17 - Análise das subfrações de F1-2 obtidas na cromatografia de troca 66 catiônica.

Figura 18 - Resultado da banda de F1-2.7 - Identificação por espectrometria de massas 67 da enzima conversora de angiotensina-I similar a peptidase transcrita em Tityus serrulatus.

Figura 19 - Alinhamento da sequência primária das enzimas conversoras de 69 angiotensina I

Figura 20 - Determinação das constantes cinéticas do substrato fluorescente Abz- 70 FRK(Dnp)P-OH utilizando a serACE-like do veneno do escorpião Tityus serrulatus...

Figura 21 - Influência do pH na atividade peptidásica de serACE-like

Figura 22 - Influência da temperatura na atividade de ACE-like. 72

Figura 23 - Ação do veneno total e das frações da DEAE sobre dinorfina 1-13 75

Figura 24 - SDS-PAGE a 13\% com coloração por prata das frações do veneno de $T .76$ serrulatus após a cromatografia de troca iônica

Figura 25 - Perfil cromatográfico da fração F3 em gel-filtração 77

Figura 26 - Resultados das subsfrações de F3 obtidas em gel-filtração 78

Figura 27 - Perfil cromatográfico da fração F5 em gel-filtração 79

Figura 28 - Resultados das subsfrações de F5 obtidas em gel-filtração 80

Figura 29 - Resultado da banda de F3-4 - Identificação da metalloserrulase 3 de Tityus serrulatus por espectrometria de massas e análise em software Peaks DB

Figura 30 - Resultado da banda de F5-1 - Identificação da metalloserrulase 4 de Tityus serrulatus por espectrometria de massas e análise em software Peaks DB.

Figura 31 - Alinhamento em BLAST da metalloserrulase 4 e metalloserrulase 383 maduras.

Figura 32 - Modelagem molecular teórica preliminar de metalloserrulase 4 e 84 metalloserrulase 3 usando o software Phyre ${ }^{2}$.

Figura 33 - Influência do pH na atividade específica de metalloserrulase 4 e 85 metalloserrulase 3 utilizando o substrato FRET. 
Figura 34 - Estudo da influência de cátions mono e bivalentes na atividade de 86 metalloserrulase 4 e metalloserrulase 3

Figura 35 - Influência da temperatura na atividade de metalloserrulase 4 e 87 metalloserrulase 3 .

Figura 36 - Perfil cromatográfico da hidrólise de Abz-GFLRRV-EDDnp por 88 metalloserrulase 3 (ms3) e metalloserrulase 4 (ms4)

Figura 37 - Estudo dos sítios preferencias dos substratos clivados por 89 metalloserrulase 4 e metalloserrulase 3 .

Figura 38 - Ensaio de inibição por soroneutralização com antivenenos comerciais 91 utilizando o substrato Abz-FLRRV-EDDnp e as peptidases isoladas metalloserrulase 4 e metalloserrulase 3 . 


\section{Lista de Abreviaturas}

Abz Radical fluorescente ácido orto-aminobenzoico

ACE Enzima conversora de Angiotensina I

ACN Acetonitrila

ADAM A Disintegrin and A Metaloproteinase

PRO Peptídeo Rico em Prolina (Proline Rich Peptide)

DEAE Diethylaminoethyl

ECE Enzima conversora de endotelina

EDDnp Grupo apagador da fluorescência N-(2,4-dinitrofenil)-etilenodiamina

EDTA Ácido etilenodiamino tetra-acético

FRET Fluorescence Resonance Energy Transfer

HPLC High Performance Liquid Chromatography / Cromatografia Líquida de Alta Performance

$\mathrm{k}_{\text {cat }} \quad$ Constante catalítica

$\mathrm{K}_{i} \quad$ Constante de Inibição

$\mathrm{K}_{m} \quad$ Constante de Michaelis-Menten

MS Espectrometria de massas

MS/MS Espectrometria de massas em tandem

NEP Neprilisina

PBS Tampão Fostato Salino

PMSF $\quad$ Fluoreto de fenil metil sufonil

MALDI- $\quad$ Matrix Assisted Laser Desorption/Ionization -Time of Flight

Tof 
Ms3 Metalloserrulase 3

Ms4 Metalloserrulase 4

PAGE Eletroforese em Gel de Poliacrilamida

SAE Soro antiescorpiônico

SAAr Soro antiaracnídico

SINAN Sistema De Informação De Agravos De Notificação de Animais Peçonhentos

serACE- Enzima Conversora de Angiotensina símile do veneno de Tityus like serrulatus

SDS Dodecil sulfato de sódio

TACE TNF-alpha converting enzyme

TEMED N,N,N',N'-Tetrametil-1,2-diaminometano

TFA Ácido trifluoroacético

TRIS Tris (hidroximetil)-aminometano

UF/min Unidade de Fluorescência por minuto

VTs Veneno de Tityus serrulatus 


\section{Lista de Abreviaturas de Aminoácidos}

Aminoácido

Alanina

Arginina

Asparagina

Aspartato

Cisteína

Fenilalanina

Glicina

Glutamato

Glutamina

Histidina

Isoleucina

Leucina

Lisina

Metionina

Prolina

Serina

Tirosina

Treonina

Triptofano

Valina
Abreviatura (3 letras)

Abreviatura (1 letra)

Ala

A

Arg

$\mathrm{R}$

Asn

$\mathrm{N}$

Asp

D

Cys

C

Phe F

Gly

G

Glu

E

Gln

Q

His

$\mathrm{H}$

Ille

I

Leu

$\mathrm{L}$

Lys

K

Met

M

Pro

P

Ser

S

Tyr

Y

Thr

$\mathrm{T}$

$\operatorname{Trp}$

W

Val

V 


\section{Sumário}

1 INTRODUÇÃ

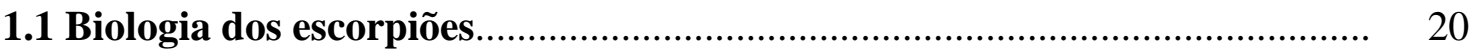

$1.2 \mathrm{O}$ envenenamento: epidemiologia e sintomas............................................. 21

1.3 Tratamento do escorpionismo: Antivenenos comerciais............................ 22

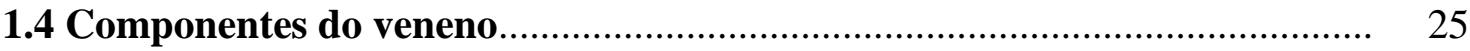

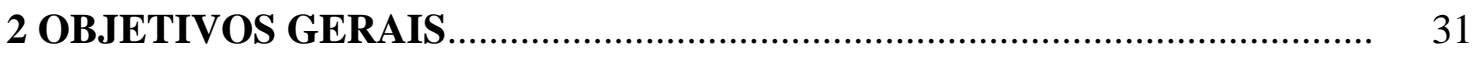

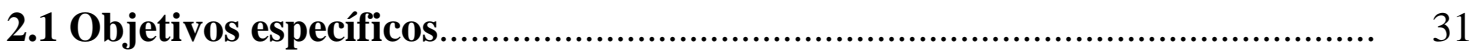

2.1.1 Objetivos específicos com o Veneno Bruto.................................................. 31

2.1.2 Objetivos Específico com as Proteases Isoladas......................................... 31

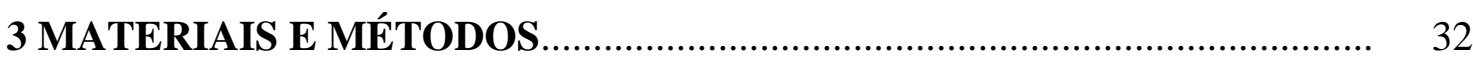



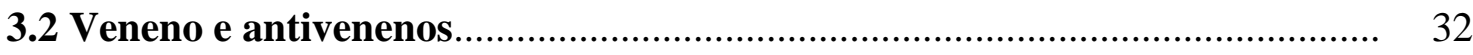

3.3 Teste de clivagem de peptídeos biologicamente ativos pelo veneno de Tityus serrulatus.

3.4 Análise dos pontos de clivagem dos novos substratos................................. 33

3.5 Testes de atividade enzimática, utilizando substratos fluorescentes............ 34

3.6 Neutralização da atividade peptidásica do veneno de Tityus serrulatus por antivenenos comerciais e inibidores.

3.6.1 Uso do Abz-GFLRRV-EDDnp e Abz-FRK(Dnp)P-OH em fluorímetro.......... 34

3.6.2 Análise da clivagem de peptídeos biologicamente ativos em cromatografia de fase reversa.

3.7 Purificação das metalopeptidases presentes no veneno de $\underline{\text { Tityus serrulatus }} \quad 36$

3.7.1 Esquema geral de purificação das peptidases serACE-like, metalloserrulase 3 e metalloserrulase 4.

3.7.2 Cromatografia de troca aniônica.

3.7.3 Caracterização das subfrações..................................................................... 38

3.7.3.1 Screening de atividade peptidásica das subfrações do veneno de $T: 38$ serrulatus.

3.7.3.2 Utilização de membrana de corte molecular.............................................. $\quad 39$

3.7.3.3 Análise em gel de SDS-PAGE 13\% ......................................................... 39 
3.7.5 Cromatografia de troca catiônica.

3.7.6. Determinação das sequências primárias das peptidases purificadas por digestão in gel e espectrometria de massas.

3.7.6.1 Análise de dados.

3.8 Análises de bioinformática das peptidases purificadas.

3.9 Análise do ponto de clivagem do substrato fluorescente Abz-GFLRRVEDDnp.

3.10 Análise do ponto de clivagem dos substratos naturais.

3.11 Determinação de condições ótimas e parâmetros cinéticos das enzimas purificadas.

3.12 Determinação das constantes catalíticas $\left(K_{m} \mathbf{e} \mathbf{k}_{c a t}\right)$ de metalloserrulase 4 e serACE-like sobre substratos FRETs

3.13 Teste de inibição por soroneutralização das metalloserrulases purificadas por antivenenos comerciais.

4 RESULTADOS

4.1 Análise da atividade peptidásica do veneno de $\underline{\text { Tityus serrulatus }}$ utilizando peptídeos biologicamente ativos (PBA).

4.2 Seleção de substratos fluorescentes para endo- e carboxipeptidases do VTs.

4.3 Ensaio de inibição do veneno total de Tityus serrulatus

4.4 Influência do íon cloreto na atividade da ACE-like do veneno de $\underline{\text { Tityus }}$ serrulatus.

4.5 Análise do potencial neutralizante dos antivenenos comerciais sobre as hidrólises dos substratos fluorescentes e peptídeos bioativos pelo veneno total

4.6 Fracionamentos do veneno total: Purificação das metalopeptidases do VTs.

4.6.1 Purificação da Enzima conversora de angiotensina I do veneno de Tityus serrulaus.

4.6.1.1 Passo I: Cromatografia de troca aniônica

4.6.1.2 Cromatografia de exclusão molecular (Gel-Filtração)

4.6.1.3 Cromatografia de troca catiônica.

4.6.1.4 Caracterizações bioquímicas da enzima conversora de angiotensina I-like.. 
4.6.2. Purificação das metalloserrulases 3 e 4 .

4.6.2.1 Passo I: Cromatografia de troca aniônica.................................................... 72

4.6.2.2 Cromatografia de exclusão molecular (Gel-Filtração) ................................. 77

4.6.2.3 Análise de massas e bioinformática......................................................... 81

4.7 Caracterizações bioquímicas das metalloserrulases 3 e 4......................... 84

4.7.1 Influência do pH na atividade proteolítica das metalloserrulases 3 e 4.......... 84

4.7.2 Influência dos sais mono e bivalentes na atividade das metalloserrulases $3 e$ 4.

4.7.3 Determinação da temperatura ideal para melhor atividade catalítica das metalloserrulases 3 e 4

4.7.4 Determinação dos pontos de hidrólise preferenciais nos substrato fluorescentes e nos peptídeos bioativos.

4.7.5 Determinação dos parâmetros cinéticos da metalloserrulase 4

4.8 Ensaio de inibição por soneutralização da atividade das metalloserrulases pelos antivenenos comerciais

5 DISCUSSÃO

5.1 Estudos com o veneno total para screening de atividades relevantes.......... 93

5.2 Purificação da Enzima Conversora de Angiotensina I do veneno de $\underline{\text { Tityus }}$ serrulatus.

5.3 Purificação das metalloserrulases: diferenciação funcional e estrutural..... 103

6 CONCLUSÕES

REFERÊNCIAS

ANEXO A - Lista de produções bibliográficas

ANEXO B - Artigo publicado: "Insights into the Hypertensive Effects of Tityus serrulatus Scorpion Venom: Purification of an Angiotensin-Converting EnzymeLike Peptidase"..... 


\section{INTRODUÇÃO \\ 1.1 Biologia dos escorpiões}

Animais peçonhentos são encontrados amplamente em todo o globo terrestre e são representados por variados táxons, abrangendo invertebrados (como cnidários, gastrópodes, insetos, aranhas, escorpiões) e vertebrados (peixes, lagartos, serpentes, aves e mamíferos) (CASEWELL et al., 2013). O desenvolvimento de órgãos especializados para a injeção da peçonha fez do envenenamento um ágil e efetivo método de defesa e/ou predação. Curiosamente, o sistema de predação por envenenamento foi proposto para alguns fósseis de animais já extintos, como para dromeossauros do gênero Sinornithosaurus spp e para o mamífero Bisonalveus browni, devido à presença de presas especializadas em ambos (FOX; SCOTT, 2005; GONG et al., 2010). Sendo assim, a ampla diversidade taxonômica de seres peçonhentos, somada ao alto nível de especialização destes animais indicam uma grande importância do veneno para sua sobrevivência durante a evolução (CASEWELL et al., 2013).

Os escorpiões são exemplo de sucesso evolutivo dentre os animais peçonhentos, por habitarem a Terra há aproximadamente 400 milhões de anos e por, geograficamente, estarem presentes em todos os continentes do planeta, com exceção da Antártida (BORTOLUZZI et al., 2007). Atualmente são catalogadas aproximadamente 2000 espécies de escorpiões que se agrupam em sete famílias em todo o mundo (CORDEIRO et al., 2015). Grande parte das espécies de escorpiões conhecidas está classificada na família Buthidae, a qual compreende os principais escorpiões de importância médica (LOURENÇO, 2015). Essa relevância para a saúde é relacionada com a capacidade destes animais de promoverem um grave quadro de envenenamento em seres humanos, podendo até mesmo levar à morte (COLOGNA et al., 2009).

O escorpião amarelo, Tityus serrulatus, é uma das principais espécies brasileiras de maior relevância para a saúde pública. A espécie foi descrita por Adolpho Lutz e Oswaldo Mello de Campos em 1922, os quais destacaram a alta toxicidade de seu veneno. Esses animais apresentam traços morfológicos bem característicos, medindo entre seis e sete centímetros na fase adulta, apresentando coloração amarelada escura por todo o corpo e a presença de serrilhas dorsais nos dois últimos segmentos de seu corpo, que dá nome à espécie desses animais (serrulatus) (Figura 01). 


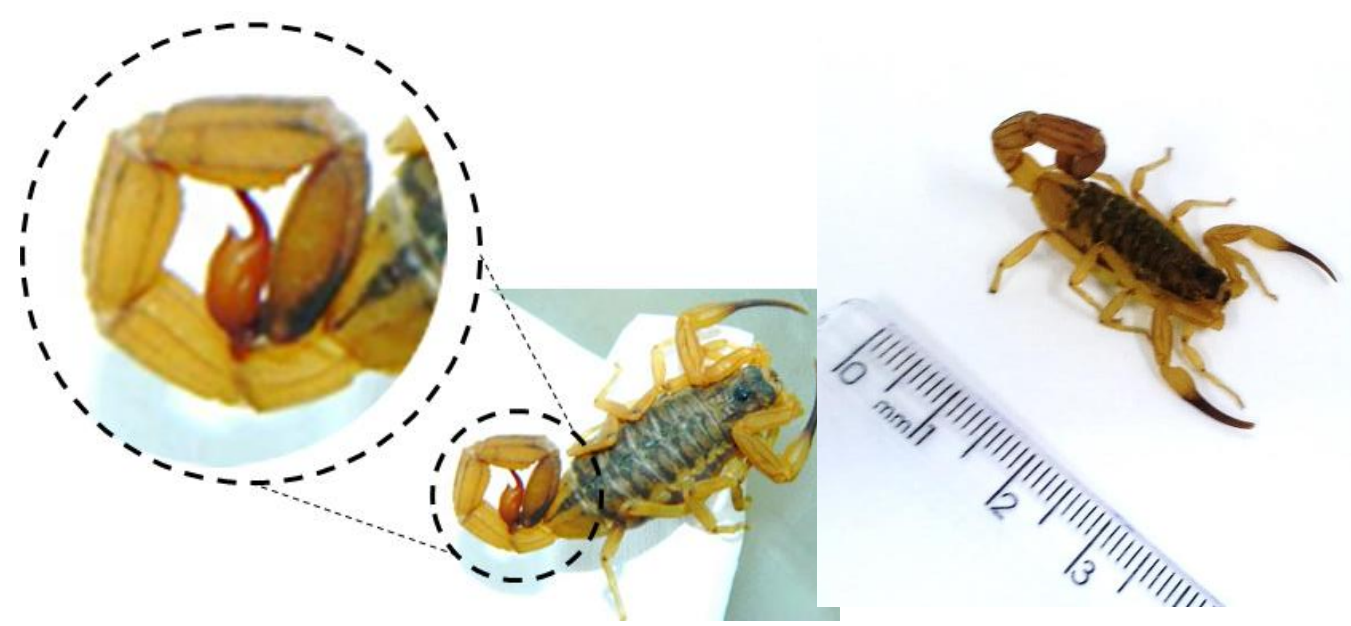

Figura 01 - Escorpião amarelo, evidenciando o tamanho, as serrilhas e a coloração (Fotos: Thiago de Jesus Oliveira / Bruno Duzzi, Daniela Cajado-Carvalho).

A reprodução partenogenética é também característica marcante desta espécie, na qual as fêmeas são capazes de gestar filhotes sem a fertilização pelo macho. Como a maioria dos artrópodes, o crescimento dos filhotes ocorre pela troca de cutícula (ecdise), atingindo a maturidade sexual após a quinta ecdise. O tempo de vida médio do escorpião T. serrulatus é de até quatro anos (WILLIAMS, 1987).

\subsection{O envenenamento: epidemiologia e sintomas}

No Brasil, são registrados, por ano, mais de 150 mil acidentes por animais peçonhentos e aproximadamente 250 óbitos. Os casos de escorpionismo, em especial, vêm aumentando gradativamente, sendo que, em 2013, representou 49\% dos envenenamentos por animais, superando casos de picadas por serpentes (17\%) e acidentes com aranhas (18,5\%), concomitantemente (dados do Sistema De Informação De Agravos De Notificação de Animais Peçonhentos, SINAN, 2017). Os principais fatores para o aumento da incidência estão atrelados à biologia dos escorpiões, em especial devido à reprodução partenogenética dos indivíduos da espécie Tityus serrulatus e pela fácil adaptação em ambientes urbanos, o que acarreta em uma maior probabilidade de ocorrência de acidentes (MINISTÉRIO DA SAÚDE, 2009). Tendo em vista a grande potência de seu veneno, o escorpião $T$. serrulatus é considerado uma das espécies de maior importância epidemiológica e médica no Brasil (SOARES et al., 2002).

O escorpionismo pode levar a complicações clínicas nos acidentados. Por vezes, a ferroada pode ser seca, ou seja, sem a inoculação de veneno, sendo que o 
envenenamento não se desenvolve (BUCARETCHI et al., 2014). Contudo, na maioria dos casos há injeção de veneno, levando a sintomas que são classificados em três principais estágios clínicos (CHIPPAUX, 2012): Estágio I, o qual tem início imediato após o acidente, é caracterizado por manifestações locais como dor, parestesia, eritema e equimose; O Estágio II é iniciado pelo aparecimento de manifestações sistêmicas moderadas, associadas ao sistema nervoso (confusão, agitação, salivação, sudorese, náuseas, fraqueza, sensação de desmaio, hipotermia/hipertermia), ao sistema cardiovascular e respiratório (taquicardia, arritmias, hipertensão/hipotensão arteriais, dispneia), alterações digestivas (diarreia, vômitos), além de desordens gerais (hiperleucocitose, hiperglicemia, acidose); O Estágio III, por sua vez, é potencialmente letal, com intensificação dos sintomas sistêmicos, como a ocorrência de choque cardiogênico, arritmia ventricular, edema pulmonar, convulsões e paralisia. Apesar de os estágios serem normalmente progressivos, existe o risco da evolução direta do estágio I para o estágio III, principalmente em crianças (CHIPPAUX, 2012).

Os efeitos do veneno e a letalidade estão diretamente relacionados com a potência do veneno: em experimento de injeção subcutânea, a dose letal mediana ( $\left.\mathrm{DL}_{50}\right)$ do veneno do escorpião amarelo Tityus serrulatus variou de $2,9 \pm 0,3 \mathrm{mg} / \mathrm{Kg}$, em ratas jovens, a 10,8 \pm 0,6 mg/Kg, em ratos machos adultos (NUNAN et al., 2001). De fato, acidentes com crianças mostram-se potencialmente mais fatais do que para adultos (GUERRA et al., 2008) que se deve pelo tamanho do corpo e/ou por uma maior susceptibilidade da barreira hematoencefálica, o que permite o acesso de toxinas ao sistema nervoso central (GUIDINE et al., 2014). Por outro lado, comparativamente, a letalidade deste mesmo veneno em insetos mostra-se cerca de um milhão de vezes mais efetiva do que em mamíferos como, por exemplo, a $\mathrm{DL}_{50}$ para o grilo preto, presa comum de escorpiões, que foi calculada em 19,91 ng/Kg (MANZOLI-PALMA et al., 2003).

\subsection{Tratamento do escorpionismo: Antivenenos comerciais}

Os soros antivenenos representam a única terapia existente e recomendada pela Organização Mundial da Saúde e pelo Ministério da Saúde para o tratamento de acidentes com animais peçonhentos. Historicamente, a produção de soros antivenenos iniciou-se por volta de 1897, na França, com a produção dos soros antitetânico e antidiftérico. O método de fabricação descrito se mantém até os dias atuais, com modificações pontuais, sendo eles: extração do soro de cavalos previamente tratado com o pool de veneno desejado, precipitação salina deste soro e digestão por pepsina, com o 
quais são obtidos os fragmentos de baixo peso, $\mathrm{F}(\mathrm{ab})_{2}$, de IgG como produto final, o que garante redução de reações adversas. Desde então, o que se tem desenvolvido na produção de antivenenos são melhorias no processo de purificação dos anticorpos, que se tornou mais refinado (CHIPPAUX; GOYFFON, 2008). A duração do processo de produção do soro é de aproximadamente seis meses (SILVA et al., 2005).

No Brasil, três instituições são responsáveis pela produção de soros capazes de neutralizar o veneno de Tityus serrulatus: Instituto Butantan (soro antiescorpiônico e soro antiaracnídico), Instituto Vital Brazil (soro antiescorpiônico) e Fundação Ezequiel Dias (soro antiescorpiônico). É interessante apontar que os soros antiescorpiônicos utilizam somente o veneno da espécie Tityus serrulatus no pool de imunização dos cavalos. No caso do soro antiaracnídico, produzido pelo Instituto Butantan, os animais são imunizados com uma mistura dos venenos do escorpião amarelo (T. serrulatus), e das aranhas armadeira (Phoneutria nigriventer) e marrom (Loxosceles gaucho). Desde 1986, a distribuição de antivenenos é gratuita, sendo o Ministério da Saúde o órgão responsável pela aquisição, distribuição, e pelo estímulo à pesquisa e ao desenvolvimento de novos produtos (SANTOS, 2005). Apesar da administração de antivenenos ser recomendada para o tratamento de escorpionismo, é relatado que, para adultos em estágio I de envenenamento, a aplicação de anestésicos muitas vezes já é efetiva para o alivio da dor (MINISTÉRIO DA SAÚDE, 2009), embora se recomende que o paciente deva ser observado até a certificação de que o quadro não se agravará.

O tempo entre a picada e a aplicação do antiveneno é um fator determinante para a efetividade do tratamento, pois caso o acidentado leve muitas horas para procurar o tratamento, o quadro pode ser irreversível (ABROUG et al., 1999). Dados do Ministério da Saúde também indicam que a letalidade aumenta progressivamente com o prolongamento do tempo de atendimento (Figura 02). 


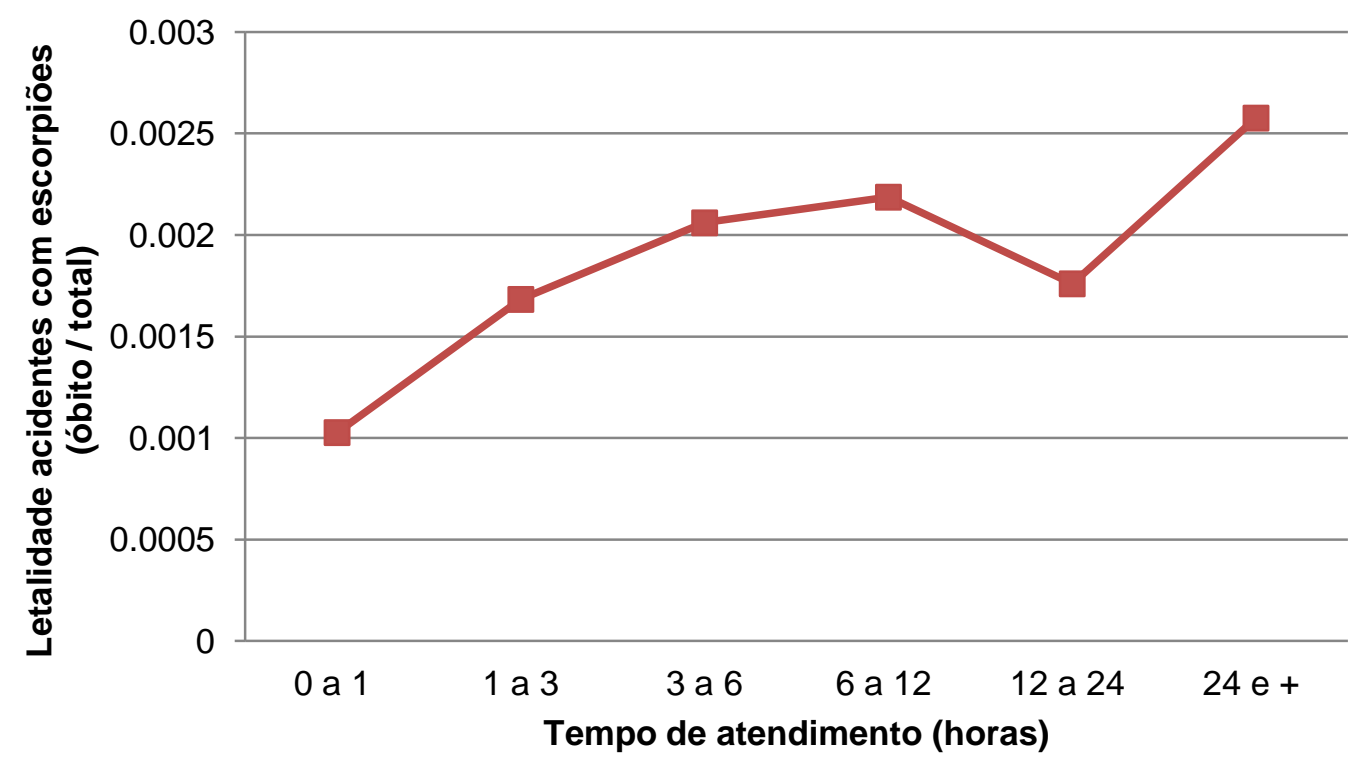

Figura 02 - Tempo de atendimento versus letalidade de acidentes por escorpiões (SINAN, 2017).

Outros trabalhos, por sua vez, demonstram que o volume de veneno injetado é determinante para a gravidade do acidente e, portanto, do tratamento a ser realizado. Foi demonstrada por estudo farmacocinético que a severidade do acidente estaria associada à quantidade de veneno circulante, e que o tratamento com o soro antiescorpiônico brasileiro é capaz de reduz os níveis de veneno no plasma de acidentados (DE REZENDE et al., 1996).

Outro fato importante a ser considerado é a utilização de altas doses de antiveneno para o tratamento de acidentados (ISMAIL, 1995). Reações adversas dos antivenenos são conhecidas durante o tratamento contra picadas de animais peçonhentos e, geralmente, estão associadas à alta quantidade de proteína heteróloga (anticorpos do cavalo) inoculadas no paciente. Por exemplo, foi reportado que, nos Estados Unidos, $60 \%$ dos pacientes apresentaram reações adversas precoces após a utilização do soro antiescorpiônico norte-americano, sendo este composto de IgGs íntegras (ISBISTER et al., 2003). As reações adversas mais comuns são urticária, febre, mal-estar e dores articulares, além de reações anafiláticas conhecidas como “doença do soro" (ISBISTER et al., 2003). Por outro lado, o novo soro antiescorpiônico norte americano contendo apenas a porção $\left.\mathrm{F}(\mathrm{ab})_{2}\right)_{2}$ do anticorpo, denominado Anascorp® apresenta menor risco de complicações adversas e é eficiente no tratamento de casos graves de escorpionismo, principalmente em crianças (BOYER et al., 2009; BOYER et al., 2013). Outro fator que 
contribui para o aparecimento de reações adversas é o contato múltiplo do paciente com antivenenos (ISBISTER et al., 2003).

Em busca da diminuição dos efeitos colaterais, alguns trabalhos trouxeram alternativas aos antivenenos comerciais para o tratamento do envenenamento por $T$. serrulatus como, por exemplo, o anticorpo monoclonal Serrumab (PUCCA et al., 2012), o qual apresenta eficiência para neutralizar as beta-toxinas como TsTx 1 e TsTx (PUCCA et al., 2014), porém tem baixa capacidade para inibir as alfa-toxinas. Deste modo, os autores discutem que, por conta das beta-toxinas serem majoritárias no veneno, a neutralização do veneno bruto in vivo seja eficaz. Recentemente, Ferreira e colaboradores (2016) apresentaram a produção de antiveneno para T. serrulatus a partir do soro de ovelhas, sendo que o veneno destoxificado por glutaraldeído foi capaz de produzir anticorpos que reconhecem o veneno bruto (FERREIRA et al., 2016). Assim, pode-se dizer que existe interesse científico e tecnológico para um aprimoramento do tratamento por imunoterapia, a fim de produzir antídotos mais eficazes, possibilitando a redução das quantidades de ampolas de antivenenos aplicadas nos pacientes.

\subsection{Componentes do veneno}

Diversas moléculas com grande diversidade de ações biológicas são componentes dos venenos animais, dentre as quais se destacam proteínas (que apresentam, ou não, atividade enzimática), peptídeos, sais e componentes inorgânicos por sua abundância e frequência. Devido ao quadro clínico apresentado pelas vítimas de escorpionismo, sabe-se que o alvo principal de suas toxinas é o sistema nervoso (FREIRE-MAIA; CAMPOS, 1989).

As neurotoxinas são peptídeos que atuam bloqueando ou excitando canais iônicos, promovendo sintomas como salivação, tremor, convulsões, entre outros (GUIDINE et al., 2014). Segundo estudo realizado por Nunan e colaboradores (2004), foi demonstrado que a tityustoxina (TsTx), uma das neurotoxinas mais letais do veneno de $T$. serrulatus, é difundida mais rapidamente em ratos jovens do que em adultos, sendo encontrada somente no cérebro de indivíduos juvenis (NUNAN et al., 2004). De fato, a barreira hematoencefálica de ratos jovens é mais permeável em comparação a de adultos, tornando o sistema nervoso central mais acessível aos componentes do veneno (GUIDINE et al., 2014). Com isso, é possível hipotetizar que a maior taxa de mortalidade em crianças - cerca de 30\% dos casos de óbito por escorpionismo em 2013 
(SINAN, 2017) - é, também, devida à maior permeabilidade desta estrutura membranar nos anos de vida iniciais.

A maioria dos efeitos desencadeados pelas neurotoxinas está associada à estimulação de neurotransmissores, em especial, as catecolaminas (TEIXEIRA et al., 2001). As catecolaminas - epinefrina (ou adrenalina), norepinefrina (ou noradrenalina) e a dopamina - são neurotransmissores liberados pela glândula adrenal, cérebro e sistema nervoso simpático, sendo que o aumento de concentração destas moléculas está associado ao quadro apresentado pelos hipertensos por promoverem vasoconstrição (DEQUATTRO; CHAN, 1972). Os envenenados por escorpiões da família Buthidae geralmente apresentam hipertensão relacionada à liberação de catecolaminas (MURTHY, 2014), sendo esta a manifestação sistêmica mais comum em pacientes de escorpionismo em estágio II e acima dos 14 anos no Brasil (BUCARETCHI et al., 2014).

Apesar da importância do conhecimento da composição da peçonha e seus mecanismos de ação, a maioria das informações sobre os componentes do veneno de $T$. serrulatus referem-se às moléculas atuantes em canais iônicos, principalmente as neurotoxinas de canais de sódio e potássio, sendo pouco conhecida a ação de outras moléculas (COLOGNA et al., 2009). Por outro lado, as peptidases são frequentemente encontradas em peçonhas animais e responsáveis diretas por diversos efeitos locais e sistêmicos, sendo os componentes majoritários de venenos de serpentes (FOX; SERRANO, 2008). Recentemente, estudos transcriptômicos têm demonstrado que as peptidases são os transcritos mais abundantes em alguns venenos de escorpião, como em $T$. bahiensis, representando cerca de $40 \%$ do veneno total (DE OLIVEIRA et al., 2015).

Alguns trabalhos atuais indicam que a presença de peptidases pode estar associada a um maior grau de toxicidade de venenos de escorpiões. Recentemente, em um estudo sobre componentes enzimáticos, Díaz-Garcíaz e colaboradores (2015) demonstraram que o veneno do escorpião cubano Rhopalurus junceus não apresenta atividades peptidásica ou fosfolipásica, mas somente atividade hialuronidásica. Tendo em vista que componentes de baixa massa molecular, como peptídeos e neurotoxinas são abundantes no veneno deste escorpião cubano, os autores sugerem que a baixa toxicidade para humanos do mesmo se deva pela sua baixa atividade peptidásica e/ou fosfolipásica (DÍAZ-GARCÍA et al., 2015). É interessante apontar que o veneno total 
do escorpião cubano $R$. junceus é utilizado no tratamento da dor, doenças inflamatórias e câncer, não apresentando toxicidade elevada para seres humanos.

A presença de peptidases em venenos de escorpiões tem sido evidenciada nos últimos anos, e pesquisas têm estipulado possíveis relações com o envenenamento. A antarease foi a primeira metalopeptidase purificada do veneno do escorpião Tityus serrulatus, sendo relacionada com a pancreatite por conta de sua capacidade de hidrolisar proteínas que participam da exocitose de vesículas (FLETCHER et al., 2010). Ortiz e colaboradores (2013) mostraram a existência de antareases em outras espécies de escorpiões da América Central (T. fasciolatus, T. pachyurus), América do Norte (Centruroides noxius) e Ásia (Mesobuthus europeus), indicando uma conservação destas moléculas na família Buthidae, independentemente da região geográfica (ORTIZ et al., 2014). Tal fato pode indicar um papel importante dessas peptidases no veneno, seja para a produção de peptídeos endógenos (VERANO-BRAGA et al., 2013) que poderão agir como toxinas, ou para agir diretamente no envenenamento de suas presas.

Em análise transcriptômica do veneno de Tityus serrulatus, dez clones diferentes de peptidases denominadas "metalloserrulases" foram encontrados, sendo que nove deles apresentaram grande similaridade com as ADAMs (denominadas de TsMS 1 a 9). Dessas dez sequências, três delas são similares à antarease, e um clone foi classificado como representante da família das gluzincinas (metalloserrulase 10), a qual possui como membros a enzima conversora de angiotensina I, a enzima conversora de endotelina I e a neprilisina (CARMO et al., 2014). Carmo e colaboradores (2014) ainda observaram que o veneno total de Tityus serrulatus tem a capacidade de clivar as cadeias $\alpha$ e $\beta$ do fibrinogênio e que provavelmente ao menos parte desta atividade é causada pelas metalloserrulases.

De modo geral, a atividade fibrinogenolítica tem sido amplamente investigada em venenos de escorpiões de outras espécies do gênero Tityus. Brazón e colaboradores (2014) demonstraram a presença de metalo e serinopeptidases (dependentes de $\mathrm{Ca}^{+2} \mathrm{e}$ tripsina-like) no veneno do escorpião colombiano Tityus discrepans que são capazes de hidrolisar o fibrinogênio. Além disso, outro fato interessante a ser destacado foi que as concentrações de íons como zinco e magnésio neste veneno se mostraram significativas e superiores a outros metais, como o cálcio (BRAZÓN et al., 2014), podendo ter influência na ativação de metalopeptidases. Em relação a escorpiões de outras famílias, foi detectada atividade fibrogenolítica por serinopeptidases no veneno do escorpião amazônico Brotheas amazonicus, sendo que o soro antiescorpiônico mostrou bloqueio 
efetivo em dose de 1:1 (HIGA et al., 2014). Para o veneno do escorpião negro da Turquia, Androctonus crassicauda, ao menos dez enzimas com atividade gelatinolítica foram encontradas, sendo inibidas simultaneamente por EDTA, aprotinina e por PMSF, provavelmente pela presença de uma serinopeptidase dependente de cálcio (CALISKAN et al., 2009). Apesar da comprovação destes fenômenos, nenhum dos trabalhos relata a purificação ou a sequência primária das peptidases responsáveis por estas atividades.

É interessante apontar que enzimas de outras classes também têm sido observadas em venenos de escorpiões. Recentemente, hialuronidases do veneno de $T$. serrulatus foram purificadas e sequenciadas, sendo um fator que contribui para a letalidade, juntamente com outras toxinas do veneno (HORTA et al., 2014). Para o escorpião colombiano Opisthacanthus elatus, fosfolipases $\left(\mathrm{PLA}_{2}\right)$ foram identificadas no veneno, bem como serinopeptidases, sendo que os autores sugerem que a atividade destas enzimas é superior à ação das neurotoxinas (ESTRADA-GÓMEZ et al., 2016). Por outro lado, para Tityus kardekai, o screening de atividade não foi capaz de detectar atividade fosfolipásica, somente gelatinolítica e hialuronidásica, corroborando com os resultados obtidos com os venenos de escorpiões brasileiros (HORTA et al., 2014; VENANCIO et al., 2013), sendo esta, provavelmente, uma característica da família Buthidae.

Nosso grupo de pesquisa constatou que os venenos dos escorpiões Tityus bahiensis e Tityus stigmurus também apresentam a atividade liberadora de Leuencefalina por meio da degradação da dinorfina 1-13 por metalopeptidases, assim como observado no veneno de T. serrulatus (VENANCIO et al., 2013). Observamos, também, que os soros comerciais produzidos pelo Instituto Butantan (soros antiescorpiônico e antiaracnídico) são capazes de bloquear apenas parcialmente esta atividade, mesmo quando utilizados em altas doses. Os experimentos realizados não puderam detectar atividade de serinopeptidases e fosfolipases com os substratos utilizados, sendo que a atividade enzimática destes escorpiões brasileiros baseia-se, principalmente, por ação de hialuronidases e metalopeptidases (VENANCIO et al., 2013).

A ação de endopeptidases e exopeptidases foi detectada sobre peptídeos endógenos do veneno de Tityus serrulatus, sendo importantes agentes pós traducionais (VERANO-BRAGA et al., 2013). Contudo, a ação isolada, tanto in vitro quanto in vivo das peptidases do veneno de $T$. serrulatus ainda não é muito estudada. Ou seja, não é possível dizer se a atividade peptidásica tem importância significativa no quadro clínico 
do envenenamento e se a mesma é eficientemente neutralizada pelos antivenenos comerciais. Para tal, é de extrema importância a purificação e a caracterização in vitro destas enzimas para melhor compreensão dos possíveis mecanismos de envenenamento e, caso observada falhas, é necessário indicar possíveis soluções para melhoria do bloqueio destas peptidases pelos soros comerciais.

Neste contexto, este trabalho buscou isolar peptidases do veneno de Tityus serrulatus (VTs), com objetivo de obter informações iniciais sobre a participação dessas moléculas no envenenamento e avaliar o potencial neutralizante dos antivenenos comerciais produzidos pelo Instituto Butantan. Estas caracterizações são inéditas na literatura e podem contribuir para um melhor conhecimento dos mecanismos de ação do veneno, além de fornecer informações importantes para a Seção de Processamento de Plasmas Hiperimunes do Instituto Butantan.

Uma vez que as peptidases do VTs foram caracterizadas como importantes agentes pós traducionais, agindo sobre polipeptídeos endógenos ao veneno e formando novos peptídeos (VERANO-BRAGA et al., 2013), focamos nossos estudos na busca de peptídeos ativos como possíveis novos substratos para o veneno e para as peptidases purificadas. Além disso, os peptídeos biologicamente ativos são moléculas fundamentais em diversos processos fisiológicos. A ação de peptídeos bioativos na sinalização celular é bem descrita, sendo essenciais para a ocorrência de processos neurais, endócrinos e imunológicos (SEWALD; JAKUBKE, 2003). Os neuropeptídios são um grupo particular de peptídeos bioativos encontrados amplamente na natureza com grande importância biológica. Apesar de inicialmente serem associados somente com o sistema nervoso central, atualmente sabe-se que neuropeptídios são também sintetizados em outras regiões do corpo, como no sistema digestivo (SEWALD et al., 2003). Por exemplo, o polipeptídeo pancreático foi primeiramente descrito em 1979, sendo extraído de pâncreas de galinhas e bovinos; em seguida, em 1982, com base no mesmo método de extração do polipeptídeo pancreático foram isolados o peptídeo YY, obtido de intestino de porcos e, posteriormente, o neuropeptídeo $\mathrm{Y}$, purificado de extrato de cérebros de porcos (CONLON, 2002). Hoje, sabe-se que estas três moléculas são reunidas no mesmo grupo de peptídeos bioativos como membros da família do neuropeptídeo $\mathrm{Y}$, por possuírem estruturas primárias e terciárias similares e mesma origem gênica (CONLON, 2002).

Sendo assim, o estudo de peptidases que têm como substrato peptídeos biologicamente ativos pode ser interessante para a compreensão de mecanismos de ação 
refinados do envenenamento escorpiônico, sendo esta a maior motivação para o desenvolvimento deste trabalho. 


\section{OBJETIVO GERAL}

Com o pressuposto de existirem poucas informações sobre as peptidases presentes no veneno do T. serrulatus (VTs), pretende-se purificar e caracterizar in vitro metalopeptidases (endo- e exopeptidases) do veneno do escorpião amarelo.

\subsection{Objetivos específicos}

\subsubsection{Objetivos específicos com o Veneno Bruto}

- Testar novos substratos bioativos.

- Analisar o efeito de inibidores específicos.

- Verificar a neutralização destas atividades pelos antivenenos comerciais do Instituto Butantan.

\subsubsection{Objetivos Específico com as Proteases Isoladas}

- Purificar proteases por screening de atividade.

- Identificar as proteases por espectrometria de massas.

- Caracterizar as preferências bioquímicas in vitro ( $\mathrm{pH}$ ideal, temperatura, $\mathrm{Km}$, kcat, influência de cátions).

- Testar a neutralização das peptidases purificadas com os antivenenos comerciais. 


\section{MATERIAIS E MÉTODOS}

\subsection{Reagentes}

Os substratos de fluorescência com supressão intramolecular de fluorescência,

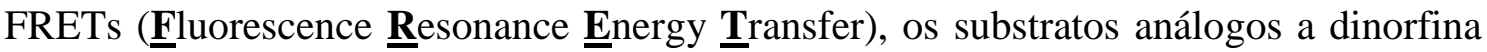
1-13 (Abz-GFLRRV-EDDnp, Abz-FLRRV-EDDnp, Abz-GFLRR-EDDnp), e o substrato de carboxipeptidases (Abz-FRK(Dnp)P-OH) foram fornecidos pelos Prof. Dr. Luiz Juliano Neto e Prof. Dr. Adriana K. Carmona, do Departamento de Biofísica da UNIFESP-EPM Com exceção do Abz-FRK(Dnp)P-OH, os substratos foram sendo gerados pelo método de síntese em fase sólida, utilizando o sintetizador automático da marca Shimadzu, modelo PSSM-8 (HIRATA et al., 1994). Por sua vez, o AbzFRK(Dnp)P-OH foi sintetizado segundo o método de síntese em fase sólida descrito (ARAUJO et al., 2000), que apresenta pequenas modificações para a inserção do (Dnp)$\mathrm{OH}$.

Os reagentes EDTA (ácido etilenodiaminotetracético), PMSF (fenilmetanosulfonilfluorido), fosforamidon, tiorfan, e 1,10-fenantrolina, bem como os peptídeos biologicamente ativos substância $\mathrm{P}$, hemopressina, peptídeo $\mathrm{Y}$, cadeia $\mathrm{B}$ da insulina, polipeptídeo pancreático, somatostatina, dinorfina 1-13, angiotensina I e bradicinina foram adquiridos na empresa Sigma-Aldrich (Saint Louis, EUA).

Os reagentes para a cromatografia de fase reversa em HPLC, acetonitrila e TFA (ácido trifluoroacético) são provenientes das empresas Carlo Erba e J.T. Baker, respectivamente.

\subsection{Veneno e antivenenos}

Os venenos de escorpiões da espécie T. serrulatus (Lotes 1634, 744, 2146) foram fornecidos em sua forma liofilizada pela Sessão de Venenos do Instituto Butantan.

Os antivenenos comerciais antiaracnídico (0706121) e antiescorpiônico (0905104/A) foram fornecidos pela Seção de Processamento de Plasmas Hiperimunes do Instituto Butantan, sendo mantidos a $4^{\circ} \mathrm{C}$ até suas utilizações. 
3.3 Teste de clivagem de peptídeos biologicamente ativos pelo veneno de $\underline{\text { Tityus }}$ serrulatus

Os peptídeos biologicamente ativos dinorfina 1-13 (30 $\mu \mathrm{M})$; neuropeptídeo Y $(23,4 \mu \mathrm{M})$; peptídeo YY $(23,2 \mu \mathrm{M})$; polipeptídeo pancreático $(22,7 \mu \mathrm{M})$; substância $\mathrm{P}$ (74,2 $\mu \mathrm{M})$; hemopressina (10 $\mu \mathrm{M})$; cadeia $\mathrm{B}$ da insulina $(71,5 \mu \mathrm{M})$; somatostatina (61 $\mu \mathrm{M})$; angiotensina I (30 $\mu \mathrm{M})$ e bradicinina $(20 \mu \mathrm{M})$, foram incubados individualmente com o veneno $(1 \mu \mathrm{g})$, durante 1 hora a $37^{\circ} \mathrm{C}$ em tampão Tris $50 \mathrm{mM}, \mathrm{NaCl} 50 \mathrm{mM}$, pH 8,0 (tampão 1) ou em tampão Tris 100 mM, NaCl 50 mM, ZnCl $210 \mu \mathrm{M}, \mathrm{pH}$ 7,0 (tampão 2). As análises foram realizadas em coluna Restek C-18 (4,6 x $250 \mathrm{~mm}$ ), utilizando gradiente de 10-60\% de B em 20 minutos em sistema de HPLC Shimadzu. Os peptídeos que foram hidrolisados pelo veneno tiveram seus picos de hidrólise coletados manualmente e analisados em espectrometria de massas para a identificação dos fragmentos originados pela hidrólise, e as atividades específicas foram determinadas ( $\mu \mathrm{M}$ de substrato hidrolisado/ $\mu \mathrm{g}$ de veneno/min), com base nas áreas dos picos em relação ao controle (apenas peptídeo e tampão). Todos os experimentos foram realizados em duplicata.

\subsection{Análise dos pontos de clivagem dos novos substratos}

Os picos correspondentes aos fragmentos gerados pela hidrólise de peptídeos bioativos por VTs em HPLC foram ressuspendidos em ácido fórmico a 0,1\% e analisados por cromatografia líquida em linha em sistema de HPLC Easy-nLC Proxeon nano acoplado a um espectrômetro Velos LTQ-Orbitrap (Thermo Fisher Scientific, Bremen, Alemanha), por meio de uma fonte de íons de nanoelectrospray. A separação foi realizada em uma coluna de $10 \mathrm{~cm}$, empacotada no laboratório com beads de $5 \mu \mathrm{M}$ Jupiter® C-18 (Phenomenex, Torrance, CA, USA). Os peptídeos foram eluídos com um gradiente linear de 5-30\% de acetonitrila em ácido fórmico a $0,1 \%$, em 45 min a 300 $\mathrm{nL} / \mathrm{min}$. O espectrômetro foi operado no modo dependente de dados e os 10 picos mais intensos foram selecionados para fragmentação a partir da dissociação induzida por colisão (CID) após adquirir cada verificação completa. As configurações para o espectrômetro foram definidas como: maior resolução de parâmetros completos MS (1 $\mu$ scan; MS faixa de massa m / z de 200-2000 com $\mathrm{R}=30000$ e um valor-alvo de 1x 104 íons; max tempo de injeção $=10 \mathrm{~ms}$ ). Para examinar fragmentos, as configurações foram: uma janela de isolamento de $2 \mathrm{Da}$, um tamanho máximo de 500 lista, uma janela 
de tempo de $30 \mathrm{~s}$, um sinal mínimo de 5000, tempo de ativação = $10 \mathrm{~ms}$ e energia de colisão normalizada $=35 \%$.

Para análise dos dados, os arquivos de dados brutos foram submetidos a buscas usando o software PEAKS studio (versão 7,5, Bioinformatics Solution, Waterloo, Canadá); contra o banco de dados SwissProt restrito para a sequência de cada peptídeo em particular (angiotensina I, bradicinina, hemopressina, peptídeo YY, neuropeptídeo Y e polipeptídeo pancreático). Um banco de dados decoy foi também utilizado para calcular a taxa de falso-positivo (FDR, false discovery rates), usando o método de decoy (MA et al., 2003; ZHANG et al., 2012). Os parâmetros da pesquisa foram: nenhuma especificidade da enzima; tolerância massa precursor definido de $\pm 10 \mathrm{ppm}$ e uma tolerância de massa de fragmento de íons de $\pm 0,5 \mathrm{Da}$; metionina oxidada (M $+15,994915 \mathrm{Da}$ ) foi definida como modificação variável. Os peptídeos identificados foram então classificados segundo a sua Média de Confiança Local (ALC) e foram filtrados por taxa de descobertas falso-positivas (FDR) $\leq 1 \%$.

\subsection{Testes de atividade enzimática, utilizando substratos fluorescentes}

Os ensaios de atividade enzimática foram realizados em fluorímetro (Victor 3, Perkin Elmer, MA, USA), ajustado para leitura de excitação e emissão em 320 e 420 $\mathrm{nm}$, respectivamente. Foram mantidos os mesmos parâmetros do aparelho em todo o trabalho. A temperatura manteve-se constante a $37^{\circ} \mathrm{C}$ e foi realizada uma leitura/minuto durante 15 minutos, sendo as placas agitadas automaticamente antes do registro de cada leitura. Os substratos utilizados foram Abz-GFLRRV-EDDnp (5 $\mu \mathrm{M})$ em tampão Tris 50 mM, NaCl 50 mM, pH 8,0, e Abz-FRK(Dnp)P-OH (4 $\mu \mathrm{M})$, em tampão Tris 100 $\mathrm{mM}, \mathrm{NaCl} 50 \mathrm{mM}, 10 \mathrm{M}, \mathrm{ZnCl}_{2} \mathrm{pH}$ 7,0, sendo o volume final $100 \mu \mathrm{L}$. A quantidade de veneno de Tityus serrulatus utilizada para os ensaios foi de $1 \mu \mathrm{g}$. Os ensaios foram analisados em software Grafit 5.0 e foram determinadas as atividades específicas das amostras (UF/ $\mu \mathrm{g}$ de veneno/min, sendo UF = unidades de fluorescência). Todos os experimentos foram realizados em duplicata.

\subsection{Neutralização da atividade peptidásica do veneno de Tityus serrulatus por antivenenos comerciais e inibidores}

3.6.1 Uso do Abz-GFLRRV-EDDnp e Abz-FRK(Dnp)P-OH em fluorímetro 
Para a padronização do uso dos antivenenos, optamos por testes fluorimétricos, utilizando o substrato Abz-GFLRRV-EDDnp $(5 \mu \mathrm{M})$ e o veneno de Tityus serrulatus (1 $\mu \mathrm{g}$ ) em tampão Tris 50 mM, NaCl 50 mM, pH 8,0. Para o substrato Abz-FRK(Dnp)P$\mathrm{OH}, 4 \mu \mathrm{M}$, o tampão utilizado foi Tris $100 \mathrm{mM}, \mathrm{NaCl} 50 \mathrm{mM}, \mathrm{ZnCl}_{2} 10 \mu \mathrm{M}$ pH 7,0, sendo usada a mesma concentração de veneno. Para ambos, o veneno foi pré-incubado à temperatura ambiente durante 30 minutos com os soros antiescorpiônico (SAE) e antiaracnídico (SAAr) nas concentrações 1:1; 1:2;1:10; 1:25; 1:50; 1:100; 1:200; 1:500 e 1:1000 (proporção veneno: antiveneno, em $\mu \mathrm{g}$ ), sendo o substrato adicionado em seguida.

Para a determinação da classe enzimática das peptidases presentes no VTs que atuam nos substratos fluorescentes, foram utilizados os inibidores EDTA, quelante de metais e inibidor de metalopeptidases, e PMSF, inibidor de serinopeptidases. Para esse experimento foram testados $1 \mu \mathrm{g}$ de veneno total e $5 \mu \mathrm{M}$ de Abz-GFLRRV-EDDnp ou $4 \mu \mathrm{M}$ de Abz-FRK(Dnp)P-OH. Para os inibidores EDTA e PMSF, as concentrações foram $50 \mathrm{mM}$ e $2 \mathrm{mM}$, respectivamente. Inibidores específicos também foram empregados: captopril (100 $\mathrm{nM}), B j$-Pro-10c $(16 \mu \mathrm{M})$, tiorfan $(10 \mu \mathrm{M})$, fosforamidon $(10 \mu \mathrm{M})$, e [des-Arg ${ }^{1}$ ]-Proctolin $(10 \mu \mathrm{M})$. Os ensaios foram realizados em fluorímetro Victor 3 (Perkin Elmer, MA, USA) e analisados em software Grafit 5.0. Os tampões utilizados para cada substrato e as condições do fluorímetro estão descritas no item 3.5. Todos os experimentos foram realizados em duplicata.

Para o estudo do efeito da concentração de íons cloreto sobre a atividade carboxipeptidásica do VTs $(1 \mu \mathrm{g})$, a hidrólise do o substrato Abz-FRK(Dnp)P-OH $(4 \mu \mathrm{g})$ foi determinada em tampão Tris $100 \mathrm{mM}, \mathrm{ZnCl} 210 \mu \mathrm{M}$, com quatro concentrações de $\mathrm{NaCl}$ : zero, $10 \mathrm{mM}, 20 \mathrm{mM}$ e $50 \mathrm{mM}$. Para comparação, os mesmos experimentos foram realizados com a enzima conversora de angiotensina I (Sigma, $50 \mathrm{ng}$ ). Os experimentos foram realizados em duplicata.

\subsubsection{Análise da clivagem de peptídeos biologicamente ativos em cromatografia de fase reversa}

Após a seleção de novos substratos biologicamente ativos para endopeptidases (neuropeptídeo Y, peptídeo YY, hemopressina e polipeptídeo pancreático), os mesmos foram submetidos a testes de inibição por soroneutralização com os dois antivenenos comerciais (SAE e SAAr), utilizando dinorfina 1-13 como controle positivo, uma vez 
que o mesmo já havia sido estudado anteriormente (VENANCIO et al., 2013). O veneno $(1 \mu \mathrm{g})$ foi primeiramente pré-incubado com os antivenenos por 30 minutos (proporção veneno: antiveneno, em $\mu \mathrm{g}$, de 1:50 e 1:100) e, em seguida, cada peptídeo individualmente foi adicionado à solução nas mesmas concentrações utilizadas anteriormente, onde a reação decorreu durante 1 hora a $37{ }^{\circ} \mathrm{C}$. Nesse caso, o tampão utilizado foi Tris $50 \mathrm{mM}, \mathrm{NaCl} 50 \mathrm{mM}, \mathrm{pH} 8,0$. Além disso, foi realizado teste de inibição, utilizando $50 \mathrm{mM}$ de EDTA com cada peptídeo individualmente na presença do veneno total.

Para o estudo específico da atividade dipeptidil-carboxipeptidásica, o veneno de Tityus serrulatus $(0,5 \mu \mathrm{g})$ foi também incubado com os peptídeos hemopressina (30 $\mu \mathrm{M})$ por 2 horas; angiotensina I $(30 \mu \mathrm{M})$, com 4 horas de incubação; bradicinina (20 $\mu \mathrm{M})$, incubada por 6 horas, em tampão Tris $100 \mathrm{mM}, \mathrm{NaCl} 50 \mathrm{mM}, \mathrm{ZnCl}_{2} 10 \mu \mathrm{M}, \mathrm{pH}$ 7,0 , à $37^{\circ} \mathrm{C}$. Conjuntamente, foi realizado o teste de inibição pelo captopril, que foi utilizado em duas concentrações: $100 \mathrm{nM}$ e $1 \mu \mathrm{M}$. O inibidor EDTA (50 mM) também foi usado. Neste caso, a dinorfina 1-13 $(30 \mu \mathrm{M})$ foi utilizada como controle negativo. Sendo assim, para este experimento, as incubações foram feitas da seguinte forma: 1) controle do peptídeo (apenas peptídeo e tampão); 2) VTs com o peptídeo; 3) VTs com peptídeo e EDTA $50 \mathrm{mM}$; 4) VTs com peptídeo e captopril $100 \mathrm{nM}$; 5) VTs com peptídeo e captopril $1 \mu \mathrm{M}$. Todos os experimentos foram realizados em duplicata. A inibição da atividade peptidásica do veneno foi calculada pela comparação das áreas dos picos referentes aos peptídeos.

As hidrólises foram analisadas por cromatografia de fase reversa em sistema HPLC utilizando coluna Restek Ultra C-18 (4,6 x $250 \mathrm{~mm})$, com detecção a $214 \mathrm{~nm}$ e fluxo de $1 \mathrm{~mL} / \mathrm{min}$. O sistema de HPLC e os tampões utilizados foram descritos acima (item 3.3).

\subsection{Purificação das metalopeptidases presentes no veneno de $\underline{\text { Tityus serrulatus }}$}

\subsubsection{Esquema geral de purificação das peptidases serACE-like, metalloserrulase 3 e metalloserrulase 4}

Para a melhor compreensão das etapas de purificação e identificação das metalopeptidases realizadas no presente trabalho, foi elaborado um esquema de purificação geral, o qual se encontra na Figura 03. 


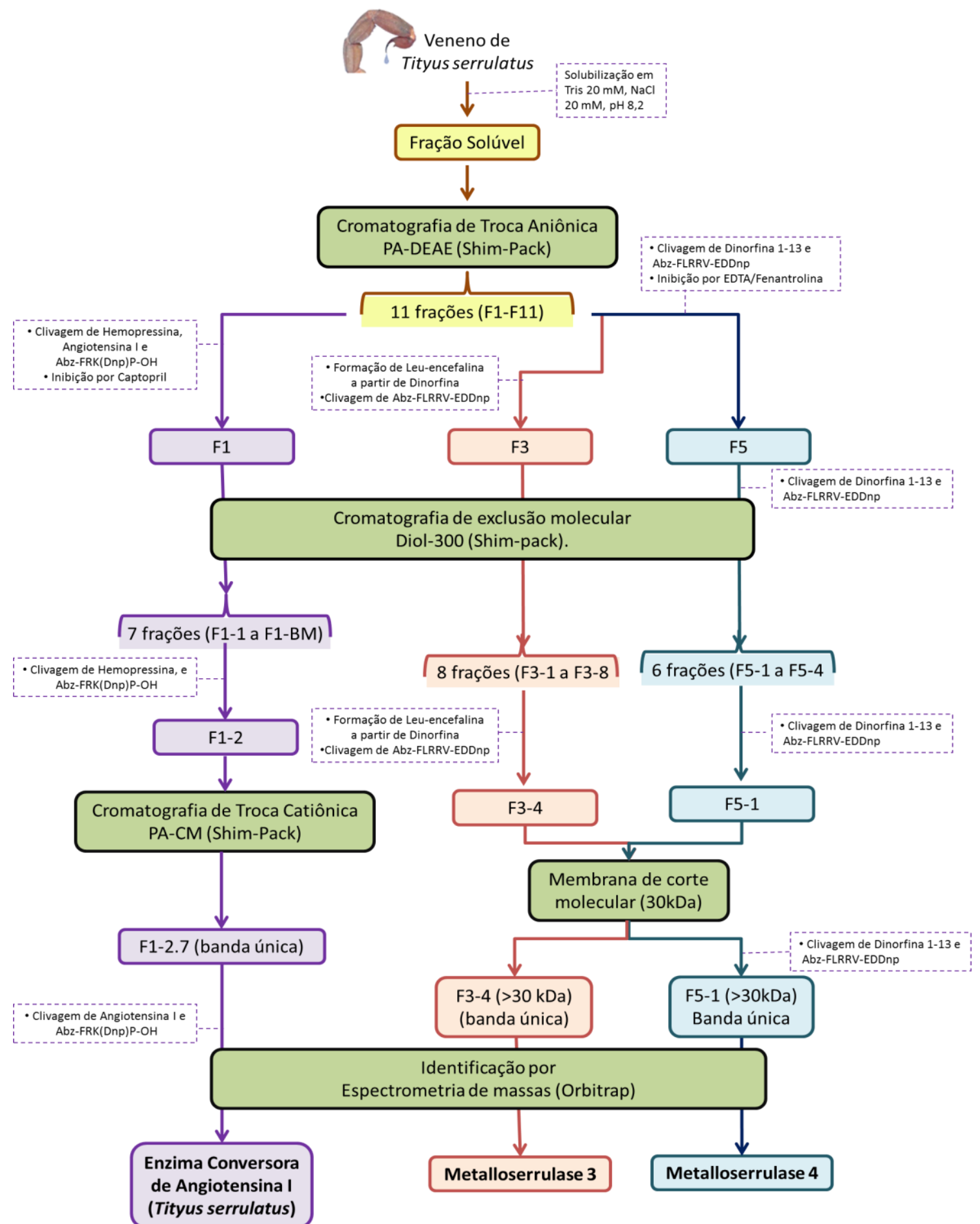

Figura 03 - Esquema representando as etapas de purificação e os screenings de atividade utilizados no presente trabalho para a obtenção de três metalopeptidases - enzima conversora de angiotesina I-like, metalloserrulase 3 e metalloserrulase 4 - a partir do veneno de Tityus serrulatus.

\subsubsection{Cromatografia de troca aniônica}

O veneno total de Tityus serrulatus $(50 \mathrm{mg}$ ) foi diluído em $5 \mathrm{~mL}$ de tampão Tris $20 \mathrm{mM}, \mathrm{NaCl} 20 \mathrm{mM}, \mathrm{pH}$ 8,2 (10 mg/mL). O veneno foi submetido à cromatografia de troca iônica em sistema HPLC (Shimatzu Co, Japão), utilizando a coluna Shim-Pack 
PA-DEAE (20 mm x $100 \mathrm{~mm}$ ), Shimatzu Co, Japão, sob fluxo $5 \mathrm{~mL} / \mathrm{min}$ em tampão A (Tris $20 \mathrm{mM}, \mathrm{NaCl} 20 \mathrm{mM}, \mathrm{pH}$ 8,2) e tampão B (tampão A com adição de $500 \mathrm{mM}$ $\mathrm{NaCl}, \mathrm{pH} 8,2$ ). Os tampões foram previamente filtrados em filtro de $20 \mu \mathrm{m}$ antes do uso. O gradiente utilizado foi de $0-80 \%$ de tampão B em 80 minutos.

\subsubsection{Caracterização das subfrações}

A quantificação de proteínas foi determinada pelo método Bradford (1976), utilizando o kit Quick Start ${ }^{\mathrm{TM}}$ Bradford Protein Assay (Bio Rad). Os procedimentos descritos a seguir (3.7.3.1 - 3.7.3.3) foram repetidos após cada etapa de purificação subsequente.

\subsubsection{Screening de atividade peptidásica das subfrações do veneno de $\underline{T \text {. serrulatus }}$}

Para o screening da atividade dipeptilcarboxipeptidásica, as frações $(5 \mu \mathrm{g})$ foram incubadas com o substrato fluorescente Abz-FRK(Dnp)P-OH, $4 \mu \mathrm{M}$, o tampão utilizado foi Tris $100 \mathrm{mM}, \mathrm{NaCl} 50 \mathrm{mM}, \mathrm{ZnCl}_{2} 10 \mu \mathrm{M}, \mathrm{pH}$ 7,0. Conjuntamente, foi verificada a clivagem de hemopressina $(30 \mu \mathrm{M})$, ou angiotensina $\mathrm{I}(30 \mu \mathrm{M})$, incubadas com as frações por 2 horas e 4 horas a $37^{\circ} \mathrm{C}$, respectivamente, no mesmo tampão de trabalho.

Para o screening das endopeptidases, o substrato Abz-GFLRRV-EDDnp (5 $\mu \mathrm{M})$ foi incubado individualmente com cada fração coletada. Em paralelo, a clivagem de dinorfina 1-13 (30 $\mu \mathrm{M})$ foi verificada, sendo que cada fração coletada foi incubada com este peptídeo em banho-maria a $37{ }^{\circ} \mathrm{C}$ por 2 horas. Estes experimentos utilizaram o tampão Tris $50 \mathrm{mM}, \mathrm{NaCl} 50 \mathrm{mM}, \mathrm{pH} 8,0$.

Os resultados utilizando substratos fluorescentes foram analisados em fluorímetro (Victor 3, Perkin Elmer, MA, USA), ajustado para leitura de excitação e emissão em 320 e $420 \mathrm{~nm}$, respectivamente e analisados em software Grafit 5.0. A temperatura manteve-se constante a $37{ }^{\circ} \mathrm{C}$ e foram realizadas uma leitura/minuto durante 15 minutos, sendo as placas agitadas antes do registro de cada leitura pelo aparelho.

Para os substratos biologicamente ativos, as análises foram realizadas por cromatografia de fase reversa em coluna Restek C-18, utilizando gradiente de 10-60\% de $\mathrm{B}$ (sendo tampão $\mathrm{A} \mathrm{H}_{2} \mathrm{O} / \mathrm{TFA}$ 0,01\% e tampão $\mathrm{B}$ ACN/solvente $\mathrm{A}$ 9:1), em 20 minutos em sistema de HPLC Shimadzu, com detecção a 214 nm. 


\subsubsection{Utilização de membrana de corte molecular}

Após selecionar as frações com melhor atividade peptidásica, foi realizada uma etapa de remoção de sal, com troca de tampão, e concentração das amostras utilizando membrana de corte molecular de $3 \mathrm{kDa}$ (Amicon Ultra-15 Centrifugal Filter Devices). Para tal, foi utilizada a centrífuga Eppendorf Centrifuge 5804R com rotação $4000 \mathrm{~g}$ por 40 minutos. As amostras foram concentradas em cinco vezes em speed vac, mantendo a temperatura a $4^{\circ} \mathrm{C}$. A membrana de corte molecular de $30 \mathrm{kDa}$ (Amicon Ultra-15 Centrifugal Filter Devices) foi também utilizada para a etapa final de refinamento da purificação das metalloserrulases.

\subsubsection{Análise em gel de SDS-PAGE 13\%}

A eletroforese em gel de SDS-PAGE 13\% foi realizada como descrito por Laemmli, 1970 utilizando o sistema de eletroforese Mini-Protean Tetra Cell (Bio-Rad). As amostras foram diluídas na proporção 1:2 em tampão de amostra em condições não redutoras, sendo aplicadas em volume máximo de $20 \mu \mathrm{L}$. Foi utilizado como padrão de massas moleculares Kaleidoscope Prestained Standards (Bio-Rad). As eletroforeses foram desenvolvidas a temperatura ambiente com duração de aproximadamente 2 horas a $90 \mathrm{~V}$. Após a corrida, o gel foi retirado do suporte e submetido à coloração com nitrato de prata (MORRISSEY, 1981) ou por Coomassie Blue Coloidal (CANDIANO et al., 2004). O gel foi fotografado e estocado em solução de ácido acético $1 \%$.

\subsubsection{Cromatografia de exclusão molecular (gel-filtração)}

A cromatografia de exclusão molecular decorreu em sistema HPLC (Shimadzu), utilizando a coluna Diol-300 (7,9 mm x $50 \mathrm{~cm})$, do fabricante Shim-pack. O tampão de eluição usado foi $200 \mathrm{mM}$ de sulfato de sódio, $10 \mathrm{mM}$ de fosfato, $\mathrm{pH} 7,0$, sendo previamente filtrado em filtro de $20 \mu \mathrm{m}$ antes de seu uso. As amostras foram cromatografadas son fluxo de $0,5 \mathrm{~mL} / \mathrm{min}$ durante 80 minutos em gradiente isocrático. O screening das frações de interesse foi realizado como descrito no item 3.7.3.1, submetidas à troca de tampão (item 3.7.3.2) e analisadas por SDS-PAGE (item 3.7.3.3).

Adicionalmente, as metalloserrulases foram fracionadas em membrana de corte molecular de $30 \mathrm{kDa}$, visando um refinamento de sua purificação. 


\subsubsection{Cromatografia de troca catiônica}

A fim de proceder a purificação da carboxipeptidase, as amostras provenientes da fração F1 pós gel-filtração foram submetidas a cromatografia de troca catiônica. A coluna utilizada foi PA-CM (Shim-pack), $20 \mathrm{~mm}$ x $100 \mathrm{~mm}$, sendo o tampão A composto de $20 \mathrm{mM}$ Tris, $20 \mathrm{mM} \mathrm{NaCl}$ pH 7,0 e tampão B, composto pelo tampão A contendo adicionalmente $0,5 \mathrm{mM}$ de $\mathrm{NaCl}$. Os tampões foram filtrados em filtro de 20 $\mu \mathrm{m}$ antes da utilização. A eluição teve duração de 80 minutos, com gradiente de $0-30 \%$ de tampão B em 40 minutos, 30-80\% B em 10 minutos e 80-100\% B em 5 minutos, sob fluxo de $5 \mathrm{~mL} / \mathrm{min}$. O screening das frações de interesse foi realizado como descrito no item 3.7.3.1, submetidas à troca de tampão (item 3.7.3.2) e analisadas por SDS-PAGE (item 3.7.3.3).

\subsubsection{Determinação das sequências primárias das peptidases purificadas por digestão in gel e espectrometria de massas}

Após a determinação de homogeneidade por SDS-PAGE das peptidases purificadas, as bandas únicas foram extraídas do gel para suas identificações por espectrometria de massas seguindo o protocolo de digestão de proteínas in gel (HANNA et al., 2000). Para tal, primeiramente, as bandas foram excisadas diretamente do gel com auxílio de uma lâmina, cortadas em pequenos pedaços (aproximadamente $2 \mathrm{~mm}$ ) e incubadas em $500 \mu \mathrm{L}$ de solução descorante $(50 \%$ de metanol, $5 \%$ de ácido acético diluídos em $\mathrm{H}_{2} \mathrm{O}$ Milli-Q) durante duas horas. Em seguida, as bandas excisadas e picotadas foram incubadas com $200 \mu \mathrm{L}$ de acetonitrila (100\%) durante 10 minutos, sendo esse passo repetido duas vezes. A solução de acetonitrila foi então removida e os tubos foram secos em speed vac para a eliminação total de resíduos de acetonitrila. Posteriormente, as amostras foram incubadas com $30 \mu \mathrm{L}$ solução redutora, contendo 10 $\mathrm{mM}$ de DTT em $100 \mathrm{mM}$ de bicarbonato de amônio, durante 30 minutos. Após a remoção desta solução, promovemos a alquilação da amostra utilizando uma solução contendo $50 \mathrm{mM}$ de iodocetamida em bicarbonato de amônio $100 \mathrm{mM}$, sendo mantida durante 30 minutos na ausência de luz. Em seguida, as amostras foram lavadas com 100 $\mathrm{mM}$ de bicarbonato de amônio durante 10 minutos e, após a remoção desta solução, foi realizada nova desidratação pela adição de acetonitrila a $100 \%$, a qual foi mantida durante 10 minutos. Este procedimento foi repetido e os excessos de acetonitrila foram evaporados em speed vac. As amostras foram incubadas com solução de tripsina (150 
ng final em solução de $50 \mathrm{mM}$ de bicarbonato de amônio), adicionados $100 \mu \mathrm{L}$ de 50 $\mathrm{mM}$ de bicarbonato de amônio, sendo incubadas em banho-maria a $37^{\circ} \mathrm{C}$ overnight .

Foi dada continuidade no procedimento pela adição de $30 \mu \mathrm{L}$ de solução de extração 1 (ácido fórmico a 5\%) durante 10 minutos. Após esse período, por conta de já conterem fragmentos peptídicos, as soluções foram transferidas para novos tubos, previamente identificados. Sob os pedaços de gel, foi adicionada $30 \mu \mathrm{L}$ de solução de extração 2 (ácido fórmico a 5\%, acetonitrila a 50\%), sendo mantida durante 10 minutos. A solução final foi transferida para os mesmos tubos novos que continham os peptídeos extraídos da solução 1. Esta etapa foi reproduzida duas vezes e, após isso, a solução com os peptídeos extraídos foi seca em speed vac. Essas amostras foram ressuspendidas em $0,1 \%$ de TFA, dessanilizadas, secas e novamente ressuspendidas em ácido fórmico a 0,1\% para serem analisadas em espectrômetro de massas no Laboratório Especial de Toxinologia Aplicada (LETA), sob responsabilidade do Dr. Leo K. Iwai. O equipamento e o método utilizados nas análises por espectrometria de massas foram os mesmos já descritos acima no item 3.4, durante a determinação dos pontos de clivagens de peptídeos bioativos que foram substratos para o VTs.

\subsubsection{Análise de dados}

Os resultados foram averiguados no software PEAKS Studio 7.5. Os parâmetros da pesquisa foram: digestão por tripsina; tolerância massa precursor definido de \pm 10 ppm e uma tolerância de massa de fragmento de íons de $\pm 0,5 \mathrm{Da}$. Foram selecionadas como modificações pós traducionais (PTM) a carbaminometilação de cisteínas, como modificação fixa, e como variável, a oxidação dos resíduos de metionina e a deamidação de asparagina e glutamina, por conta do tratamento utilizado na extração da banda do gel. O índice de falsas descobertas (False Discovery Rate, FDR) foi ajustado para $<0.01 \%$. O bancos de dado foi montado a partir de sequências obtidas no UNIPROT/ SwissProt (554567 sequências). Adicionalmente, para análise da ACE, foi montado um banco de dados com sequências depositadas no UNIPROT, com restrição para o gênero Tityus, em conjunto com as sequências de ACEs obtidas por análise transcriptômica pelos colaboradores Dra. Ursula Castro de Oliveira e Dr. Inácio Junqueira de Azevedo, do Laboratório Especial de Toxinologia Aplicada do Instituto Butantan, totalizando 383 sequências. 


\subsection{Análises de bioinformática das peptidases purificadas}

O alinhamento das sequências primárias das enzimas conversoras de angiotensina das espécies Homo sapiens (AAA60611.1); Tityus serrulatus (Tser01365); Tityus bahiensis (Tbah00054); Tityus obscurus (Tobs01411) foi realizado no software


Expectation) (KUMAR et al., 2016).

Para as metalloserrulases, as sequências foram analisadas na ferramenta Blast (NCBi) >> Global alignment >> Needleman-Wunsch Global Align Protein Sequences. Além do alinhamento, o grau de identidade e a similaridade entre as sequências foram obtidos.

Para a visualização da modelagem teórica das metalloserrulases, as sequências foram submetidas no software online Phyre $^{2}$ (KELLEY; STERNBERG, 2009) na opção "Intense mode", o qual realiza o modelo com base na homologia entre as sequências primárias. Os modelos selecionados tiveram confiança acima de $97 \%$ e acurácia $>90 \%$. Os arquivos, em formato PDB, foram submetidos ao software Discovery Studio 4.1, onde os sítios catalíticos e o provável met-turn foram destacados.

\subsection{Análise do ponto de clivagem do substrato fluorescente Abz-GFLRRV-EDDnp}

Para a determinação do ponto de clivagem do substrato Abz-GFLRRV-EDDnp, a metalloserrulase 3 e a metalloserrulase 4, $150 \mathrm{ng}$, foram incubadas em tampão bórax $50 \mathrm{mM}$ pH 8,5 durante 15 minutos (volume final $100 \mu \mathrm{L}$ ). A cinética foi acompanhada no fluorímetro Victor 3 (Perkin Elmer, MA, USA) e as clivagem foram posteriormente observadas em cromatografia de fase reversa em HPLC (Shimadzu) em coluna Restek C-18, sendo o método variando a concentração de tampão B (10\% de tampão A diluído em acetonitrila, onde o tampão A é 0,01\% TFA em $\mathrm{H}_{2} \mathrm{O}$ deionizada) em 30-80\% em 25 minutos. Os picos foram coletados manualmente e, em seguida, os pontos de clivagem das amostras foram determinados em espectrômetro de massas MALDI-TOF no Laboratório de Bioquímica e Biofísica do Instituto Butantan, sob a supervisão do Dr. Daniel C. Pimenta. 


\subsection{Análise do ponto de clivagem dos substratos naturais}

As metalloserrulases 3 e 4 (150 ng) foram incubadas com os substratos naturais dinorfina 1-13, neuropeptideo Y, peptídeo YY e polipeptídeo pancreático durante 6 horas à $37^{\circ} \mathrm{C}$, em tampão ácido bórico 50 mM, NaCl 50 mM, pH 8. Em adendo, a serACE-like (150 ng) foi incubada com angiotensina I overnight em tampão Tris 100 $\mathrm{mM}, \mathrm{NaCl} 50 \mathrm{mM}, 10 \mu \mathrm{M} \mathrm{ZnCl}$, $\mathrm{pH}$ 7,0. As clivagens foram constatadas por cromatografia de fase reversa C-18 e os produtos de hidrólise foram então analisados por espectrometria de massas (Orbitrap) no Laboratório Especial de Toxinologia Aplicada. A análise das sequências foi feita no software Peaks 8.0, sendo empregados os seguintes parâmetros para o sequenciamento de novo: Tolerância de erro de massa parental de 0,5 Da; tolerância de erro de massa do fragmento: 0,2 Da nenhuma enzima; oxidação da metionina e acetilação do $\mathrm{N}$-terminal foram selecionadas como modificações variáveis. Foram selecionados os peptídeos obtidos pelo sequenciamento de novo com $\mathrm{ALC} \geq 80 \%$ que correspondiam à sequência dos substratos. A fím de se estudar a especificidade primária das peptidases, os resíduos de aminoácidos nas posições P3-P3' foram determinados a partir dos pontos de clivagens obtidos (SCHECHTER; BERGER, 1967), e analisadas na ferramenta IceLogo (COLAERT et al., 2009), permitindo a visualização da frequência dos resíduos de aminoácidos e seu grau de conservação em diferentes posições.

\subsection{Determinação de condições ótimas e parâmetros cinéticos das enzimas purificadas}

Para a determinação do pH ótimo de atividade catalítica das enzimas purificadas (metalloserrulase 3, metalloserrulase 4 e serACE-like) os seguintes tampões foram preparados, seguindo o recomendado por Stoll e Blanchard (1990): fosfato de sódio (pH 5,0 - 7,5), bórax/ácido bórico ( $\mathrm{pH} 7,6$ - 9,2) e borato de sódio ( $\mathrm{pH} \mathrm{9,2-10),} \mathrm{todos} \mathrm{na}$ concentração final de $50 \mathrm{mM}$ (STOLL; BLANCHARD, 1990). O substrato para as metalloserrulases foi o Abz-FLRRV-EDDnp e para a serACE-like, Abz-FRK(Dnp)P$\mathrm{OH}$.

A influência da temperatura na velocidade de hidrólise dos substratos FRETs das metalloserrulases e da serACE-like também foi analisada. Para tal, a atividade das peptidases foi analisada em temperaturas entre $22{ }^{\circ} \mathrm{C}$ e $42{ }^{\circ} \mathrm{C}$, em intervalos de $5{ }^{\circ} \mathrm{C}$, utilizando o melhor tampão indicado com base nos resultados dos experimentos anteriores ( $\mathrm{pH}$ e influência de sais). Para a certificação da temperatura correta no poço, 
cada enzima foi previamente climatizada com incubação de 15 minutos em tampão na temperatura desejada e, após esse período, o substrato foi adicionado, iniciando a reação. Todos os resultados foram obtidos em fluorímetro Victor $3^{\mathrm{TM}}$ (Perkin-Elmer, Boston, MA, USA), com 1 leitura por minuto durante 15 minutos. Os ensaios foram realizados em triplicatas, e os desvios padrões foram calculados. Os gráficos foram plotados no software GraphPad Prism.

Em adição, a influência de íons monovalentes e bivalentes sobre a atividade das metalloserrulases foi avaliada na presença de diversos cátions $\left(\mathrm{Na}^{+}, \mathrm{K}^{+}, \mathrm{Li}^{+}, \mathrm{Mg}^{+2}\right.$, $\mathrm{Ca}^{+2}$ ), todos na concentração final $50 \mathrm{mM}$, de acordo com a série de Hofmeister na forma de cloreto. A velocidade de hidrólise na presença e ausência do íon foi avaliada, identificando possíveis alterações na atividade enzimática. Os ensaios foram realizados em triplicatas, e os desvios padrões foram calculados.

\subsection{Determinação das constantes catalíticas $\left(K_{m}\right.$ e $\left.\mathbf{k}_{c a t}\right)$ de metalloserrulase 4 e serACE-like sobre substratos FRETs}

Para a determinação das constantes de Michaelis-Menten $\left(\mathrm{K}_{m}\right)$ e catalíticas $\left(\mathrm{k}_{c a t}\right)$, quantidades sequenciais de substrato fluorescente foram utilizadas. Para a metalloserrulase 4 os substratos analisados foram: Abz-GFLRRV-EDDnp; AbzFLRRV-EDDnp; Abz-GFLRR-EDDnp e Abz-GGFLR-EDDnp nas concentrações 2,5 $\mu \mathrm{M}, 5 \mu \mathrm{M}, 10 \mu \mathrm{M}, 15 \mu \mathrm{M}, 25 \mu \mathrm{M}, 50 \mu \mathrm{M}, 100 \mu \mathrm{M}$ e $200 \mu \mathrm{M}$. O tampão utilizado para metalloserrulase 4 foi o bórax $50 \mathrm{mM} \mathrm{pH} \mathrm{8,5,} \mathrm{com} \mathrm{exceção} \mathrm{do} \mathrm{substrato} \mathrm{Abz-FLRRV-}$ EDDnp, que também teve suas constantes determinadas em $\mathrm{pH}$ fisiológico (PBS $\mathrm{pH}$ 7,4). Para serACE-like, o substrato analisado foi o Abz-FRK(Dnp)P-OH nas concentrações $2 \mu \mathrm{M}, 4 \mu \mathrm{M}, 8 \mu \mathrm{M}, 16 \mu \mathrm{M}, 20 \mu \mathrm{M}, 40 \mu \mathrm{M}, 80 \mu \mathrm{M}, 100 \mu \mathrm{M}, 200 \mu \mathrm{M}$, em tampão Tris $100 \mathrm{mM}, \mathrm{NaCl} 50 \mathrm{mM}, \mathrm{ZnCl}_{2} 10 \mu \mathrm{M}, \mathrm{pH} 7,0$. O monitoramento das atividades enzimáticas foi realizado em fluorímetro Victor 3 durante 15 minutos, sob temperatura constante $\left(37^{\circ} \mathrm{C}\right)$. As cinéticas foram obtidas em condições onde $\mathrm{o}$ consumo de substrato fosse inferior a $10 \%$ (velocidades iniciais de hidrólise). As velocidades de hidrólise, velocidade máxima e $\mathrm{K}_{m}$ foram calculados utilizando o software Grafit 5.0.

Para o cálculo de $\mathrm{k}_{\text {cat }}\left(\mathrm{s}^{-1}\right)$, as velocidades obtidas em UF/min foram convertidas para $\mu \mathrm{M} / \mathrm{min}$. A conversão foi baseada na hidrólise total de $1 \mu \mathrm{M}$ de Abz-FLRRVEDDnp $(1440 \mathrm{UF}=1 \mu \mathrm{M})$. A concentração de cada enzima também foi convertida para 
$\mu \mathrm{M}$ com base nas suas massas molares (72 kDa para serACE-like e $25 \mathrm{kDa}$ para ms4). Todos os experimentos foram realizados em triplicatas.

\subsection{Teste de inibição por soroneutralização das metalloserrulases purificadas por antivenenos comerciais}

Após a determinação das condições ótimas para o estudo das metalloserrulases, o potencial neutralizante dos antivenenos comerciais (antiaracnidico, lote 0706121 - e antiescorpiônico, lote 0905104/A) foi avaliado em ensaios in vitro. Para tal, as peptidases ms 3 e ms4 foram pré-incubadas com os antivenenos comerciais durante 30 minutos em tampão PBS pH 7,4, em placa de 96 poços branca. As concentrações utilizadas foram $1: 10 ; 1: 25 ; 1: 50 ; 1: 100 ; 1: 200 ; 1: 500$ e 1:1000 (proporção veneno: antiveneno, em $\mu \mathrm{g})$. Após esse período, o substrato Abz-FLRRV-EDDnp (1/4 $\left.\mathrm{K}_{m}\right)$ foi adicionado e a inibição por soroneutralização determinada em fluorímetro. 


\section{RESULTADOS}

\subsection{Análise da atividade peptidásica do veneno de Tityus serrulatus utilizando peptídeos biologicamente ativos (PBA)}

Primeiramente, foi realizada a seleção de possíveis novos substratos para as peptidases do veneno de Tityus serrulatus. Os peptídeos testados foram: dinorfina 1-13, utilizada como controle positivo (VENANCIO et al., 2013); neuropeptídeo Y; peptídeo YY; polipeptídeo pancreático; substância P; hemopressina; cadeia B da insulina; somatostatina, angiotensina I e bradicinina. O veneno $(1 \mu \mathrm{g})$ foi incubado com cada peptídeo separadamente a $37{ }^{\circ} \mathrm{C}$ em tampão Tris $50 \mathrm{mM}, \mathrm{NaCl} 50 \mathrm{mM}, \mathrm{pH} 8,0$ (denominado Tampão 1) ou em tampão Tris 100 mM, NaCl 50 mM, ZnCl $210 \mu \mathrm{M}, \mathrm{pH}$ 7,0 (denominado Tampão 2). As análises foram realizadas em coluna Restek C-18 utilizando gradiente de 10-60\% de B em 20 minutos em sistema de HPLC Shimadzu. O resultado pode ser observado na Tabela 01 .

Tabela 01 - Seleção de novos substratos para o veneno de Tityus serrulatus em tampão 1 (Tris $50 \mathrm{mM}, \mathrm{NaCl} 50 \mathrm{mM}$, pH 8) e tampão 2 (Tris $100 \mathrm{mM}, \mathrm{NaCl} 50 \mathrm{mM}, \mathrm{ZnCl}_{2} 10$ $\mu \mathrm{M}, \mathrm{pH}$ 7). As análises foram realizadas em cromatografia de fase reversa utilizando coluna Restek C-18 em sistema de HPLC (Shimadzu), com gradiente de $10-60 \%$ de B em 20 minutos.

\begin{tabular}{c|c|c}
\hline Peptídeo & $\begin{array}{c}\text { Atividade específica - } \\
\text { Tampão 1 }(\mu \mathrm{M} / \mu \mathrm{g} / \mathrm{min})\end{array}$ & $\begin{array}{c}\text { Atividade específica - } \\
\text { Tampão 2 }(\boldsymbol{\mu M} / \mu \mathrm{g} / \mathrm{min})\end{array}$ \\
\hline Neuropeptideo Y & $0,29 \pm 0,03$ & n.d. \\
\hline Peptideo YY & $0,29 \pm 0,03$ & n.d. \\
\hline Dinorfina 1-13 & $0,25 \pm 0,02$ & $0,22 \pm 0,04$ \\
\hline Hemopressina & $0,070 \pm 0,005$ & $0,39 \pm 0,01$ \\
\hline Polipeptídeo pancreático & $0,050 \pm 0,001$ & n.d. \\
\hline Substância P & $<0,001$ & n.h.h. \\
\hline Somatostatina & n.h & n.h. \\
\hline Cadeia B da Insulina & n.h & $0,054 \pm 0,010$ \\
\hline Angiotensina I & n.h & $0,044 \pm 0,003$ \\
\hline Bradicinina & n.h & n.d. \\
\hline Neurotensina & n.h & \\
\hline
\end{tabular}

n.h=não foi observada hidrólise;

n.d. = não determinado. 
A Tabela 01 demonstra que o veneno de Tityus serrulatus apresenta especificidade quanto à proteólise de peptídeos biologicamente ativos. Em especial, os peptídeos membros da família do neuropeptídeo Y, que inclui o peptídeo YY e polipeptídeo pancreático, foram eficientemente clivados pelo veneno, assim como hemopressina e dinorfina 1-13.

Adicionalmente, tendo em vista que normalmente peptidases são sensíveis a características bioquímicas no tampão de trabalho, em especial a enzima conversora de angiotensina I, foram realizados testes de atividade com o Tampão 2 que contém $10 \mu \mathrm{M}$ de $\mathrm{ZnCl}_{2}$ e pH neutro. Como resultado, angiotensina I e bradicinina foram hidrolisadas, além da dinorfina I e da hemopressina. A somatostatina, a cadeia B da insulina e a substância P não foram hidrolisadas pelo veneno em nenhum dos tampões testados, mesmo após longos períodos de incubação, indicando especificidade por parte das peptidases existentes neste veneno.

Os picos de hidrólise dos novos substratos hidrolisados quando da utilização do Tampão 1 foram coletados e analisados por espectrometria de massa. $\mathrm{O}$ resultado das clivagens encontra-se na Tabela 02.

Tabela 02 - Determinação dos produtos de hidrólise dos novos substratos do veneno total de $T$. serrulatus em tampão Tris $50 \mathrm{mM}, \mathrm{NaCl} 50 \mathrm{mM}, \mathrm{pH} 8,0$. Resultados obtidos por espectrometria de massas (Orbitrap).

\begin{tabular}{|c|c|c|c|}
\hline Peptídeo & Sequência & Massa (Da) & Fragmento \\
\hline & PVNFKFLSH* & 1087,5815 & \\
\hline \multirow[t]{6}{*}{ Hemopressina } & PVNFKFL-- & 863,4905 & $1-7$ \\
\hline & PVNFKF--- & 750,4064 & $1-6$ \\
\hline & PVNFK---- & 603,338 & $1-5$ \\
\hline & $----\mathrm{KFLSH}$ & 630,3489 & $5-9$ \\
\hline & $-----\mathrm{FLSH}$ & 502,254 & $6-9$ \\
\hline & YPIKPEAPGEDASPEELNRYYASLRHYLNLVTRQRY-NH2* & 4310,80 & \\
\hline \multirow[t]{14}{*}{ Peptídeo YY } & YPIKPEAPGEDA--------------------------- & 1285,619 & $1-12$ \\
\hline & YPIKPEAPGED------------------------- & 1214,5819 & 1,11 \\
\hline & 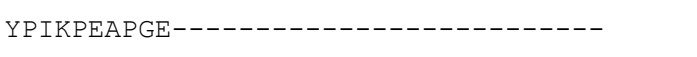 & 1099,5549 & $1-10$ \\
\hline & YPIKPEAPG---------------------------- & 970,5123 & $1-9$ \\
\hline & YPIKPEAP------------------------------- & 913,4908 & $1-8$ \\
\hline & $---------E D A S P E E L N R Y Y A--------------$ & 1555,679 & $10-22$ \\
\hline & ----------DASPEELNRYYA-------------- & 1426,6365 & $11-22$ \\
\hline & -----------AS PEELNRYYA-------------- & 1311,6095 & $12-22$ \\
\hline & ------------ SPEELNRYYA---------------- & 1240,5724 & $13-22$ \\
\hline & ---------------EELNRYYAS-------------- & 1143,5197 & $15-23$ \\
\hline & ---------------EELNRYYA--------------- & 1056,488 & $15-22$ \\
\hline & -----------AS PEELNRYYASLRHYLNLVTR--- & 2664,3772 & $12-33$ \\
\hline & -------------------YASLRHYLNLVTRQR- & 1889,0383 & $20-35$ \\
\hline & --------------------YASLRHYLNLVT---- & 1448,7776 & $21-32$ \\
\hline
\end{tabular}




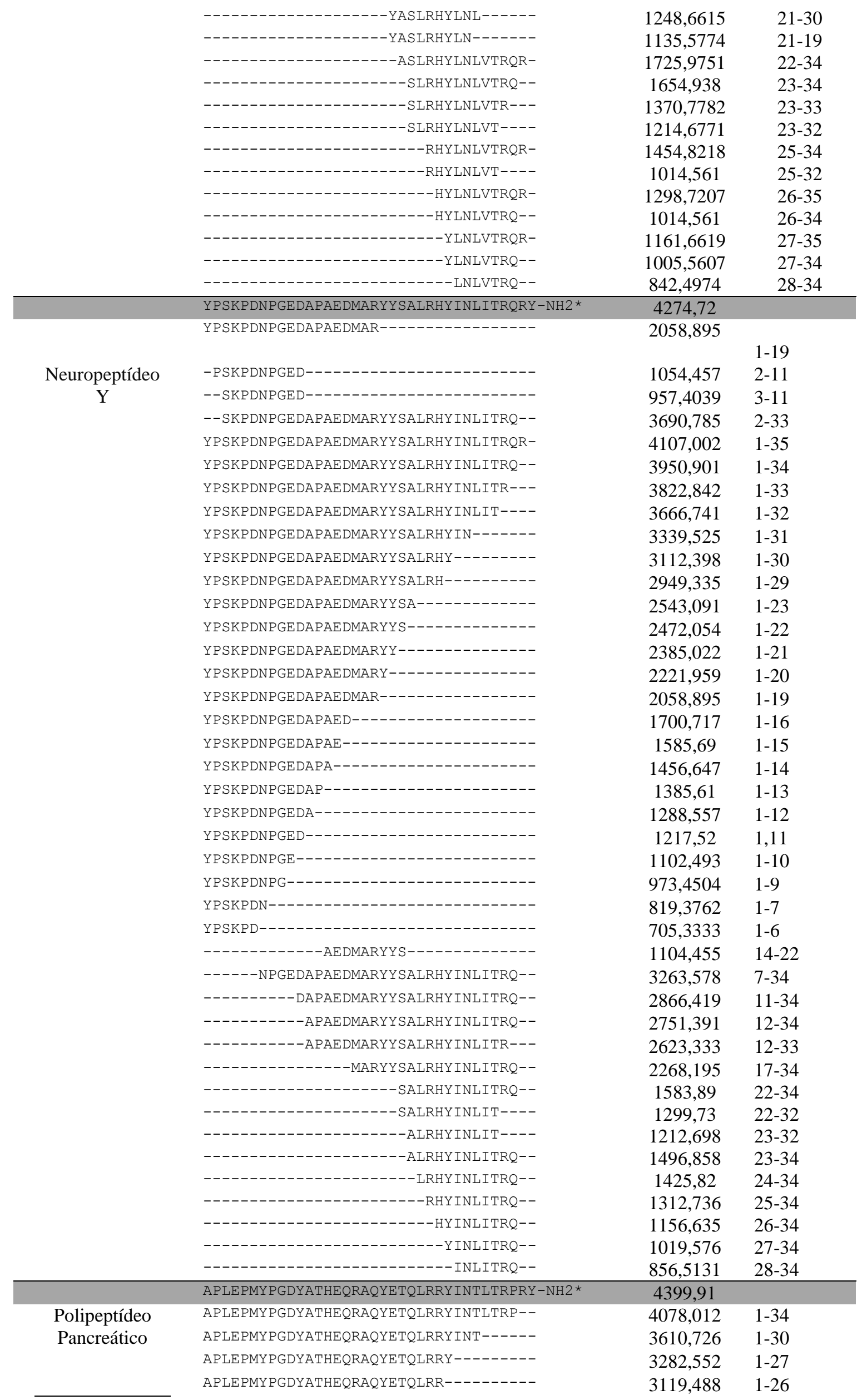




\begin{tabular}{|c|c|c|}
\hline APLEPMYPGDYATHEQRAQYETQLR---------- & 2963,387 & $1-25$ \\
\hline APLEPMYPGDYATHEQRAQYETQL----------- & 2807,286 & $1-24$ \\
\hline APLEPMYPGDYATHEQRAQYETQ------------- & 2694,202 & $1-23$ \\
\hline APLEPMYPGDYATHEQRAQYET------------ & 2566,143 & 1,22 \\
\hline APLEPMYPGDYATHEQRAQY---------------- & 2336,053 & $1-20$ \\
\hline APLEPMYPGDYATHEQRAQ----------------- & 2172,99 & $1-19$ \\
\hline APLEPMYPGDYATHEQRA------------------ & 2044,9313 & $1-18$ \\
\hline APLEPMYPGDYATHE------------------- & 1689,734 & $1-15$ \\
\hline 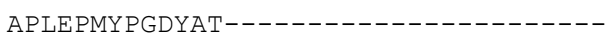 & 1423,633 & $1-13$ \\
\hline APLEPMYPGDYA ------------------------ & 1322,585 & $1-12$ \\
\hline APLEPMYPGDY -------------------------- & 1251,548 & $1-11$ \\
\hline 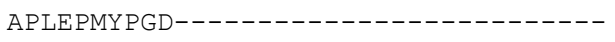 & 1088,485 & $1-10$ \\
\hline -PLEPMYPGDYATHEQRAQYETQL------------ & 2736,249 & $2-24$ \\
\hline --------GDYATHEQRAQYETQLRRYINTLTRPR- & 3335,687 & $9-35$ \\
\hline --------GDYATHEQRAQYETQLRRYINTLTRP-- & 3179,586 & $9-34$ \\
\hline --------GDYATHEQRA------------------- & 1146,505 & $9-18$ \\
\hline ---------YATHEQRAQYETQLRRYINTLTRP-- & 3007,538 & $11-24$ \\
\hline ----------YATHEQRAQYETQL------------ & 2963,387 & $11-24$ \\
\hline ----------ATHEQRAQYETQ------------ & 1460,664 & $11-23$ \\
\hline -----------ATHEQRAQYE--------------- & 1231,558 & $11-21$ \\
\hline ------------THEQRAQYETQ------------- & 1389,627 & $12-23$ \\
\hline ------------THEQRAQYE--------------- & 1160,521 & $12-21$ \\
\hline ------------HEQRAQYETQ------------ & 1288,58 & $13-23$ \\
\hline -------------HEQRAQYE--------------- & 1059,473 & $13-21$ \\
\hline --------------EQRAQYETQL------------ & 1689,734 & $14-24$ \\
\hline ---------------QRAQYETQL ------------ & 3610,726 & $15-24$ \\
\hline --------------QRAQYETQLRRYINTLTRPR- & 2562,389 & $15-35$ \\
\hline -------------------------RYINTLTRP-- & 1132,635 & $26-34$ \\
\hline --------------------------YINTLTRPR- & 1132,635 & $27-35$ \\
\hline --------------------------YINTLTRP-- & 976,5342 & $27-34$ \\
\hline
\end{tabular}

*= sequência do peptídeo nativo

A análise de espectrometria de massas dos fragmentos revelou diferentes quantidades de produtos formados - hemopressina (5 fragmentos); peptídeo YY (23 fragmentos); neuropeptídeo Y (40 fragmentos); polipeptídeo pancreático (31 fragmentos) - e apresentando diferentes tamanhos como, por exemplo, para neuropeptídeo $\mathrm{Y}$ foram encontradas sequências curtas $\left(\mathrm{NPY}_{1-6}\right)$ e longas $\left(\mathrm{NPY}_{1-35}\right)$. Por fim, outro fator interessante observado foi em relação aos membros da família do neuropeptídeo $\mathrm{Y}$, pois em todos os fragmentos gerados houve a remoção da tirosina amidada $\left(\mathrm{Y}_{36}-\mathrm{NH}_{2}\right)$ presente no C-terminal dos peptídeos.

Os peptídeos hidrolisados exclusivamente no tampão da ACE (Tampão 2) também tiveram seus picos coletados e analisados em espectrômetro de massas. Os resultados estão apresentados na Tabela 03. 
Tabela 03 - Determinação dos produtos de clivagem da angiotensina I e bradicinina hidrolisadas pelo veneno de T. serrulatus em tampão Tris $100 \mathrm{mM}, \mathrm{NaCl} 50$ $\mathrm{mM}, \mathrm{ZnCl}_{2} 10 \mu \mathrm{M}, \mathrm{pH} 7,0$. Resultados obtidos por espectrometria de massas (Orbitrap).

\begin{tabular}{|c|c|c|c|}
\hline Peptídeo original & Fragmento & Identificação do fragmento & Massa (kDa) \\
\hline \multirow{7}{*}{ Angiotensina I } & DRVY------ & Inativo Ang 1-4 & 551,270 \\
\hline & $----I H P F H L$ & Inativo Ang 5-10 & 762,418 \\
\hline & $-----\mathrm{HPFHL}$ & Inativo Ang 6-10 & 649,334 \\
\hline & DRVYIHP--- & Ang $1-7$ & 898,466 \\
\hline & DRVYIHPF-- & Ang II & 1045,465 \\
\hline & -RVYIHPF-- & Ang III & 930,5075 \\
\hline & $-------\mathrm{FHL}$ & Inativo Ang $8-10$ & 415,2219 \\
\hline \multirow{3}{*}{ Bradicinina } & RPPGF---- & Inativo $\mathrm{BK}_{1-5}$ & 572,31 \\
\hline & RPPGFSP-- & Inativo $\mathrm{BK}_{1-7}$ & 756,39 \\
\hline & --PGFSPFR & Inativo $\mathrm{BK}_{3-9}$ & 806,4075 \\
\hline
\end{tabular}

Como resultado da clivagem da angiotensina I e bradicinina pelo veneno total, foram originados sete peptídeos a partir da angiotensina I, dentre os quais quatro são reportados como inativos e três ativos, angiotensina II, angiotensina III e angiotensina 1-7, com atividades biológicas já descritas. Em relação à bradicinina, a clivagem pelo VTs originou três produtos de hidrólise, sendo fragmentos sem atividade.

\subsection{Seleção de substratos fluorescentes para endo- e carboxipeptidases do VTs}

Como foi possível observar pelos produtos de hidrólise dos substratos peptídicos biologicamente ativos, há evidências da ação de endo- e exopeptidases no veneno do $T$. serrulatus. Assim, antes do início do processo de purificação destas peptidases, foi padronizado o uso de substratos fluorescentes para a seleção de endopeptidases e carboxipeptidases presentes no VTs.

O veneno de Tityus serrulatus (VTs), $1 \mu \mathrm{g}$, foi inicialmente testado nos substratos fluorescentes Abz-GFLRRV-EDDnp $(5 \mu \mathrm{M})$, já utilizado pelo nosso grupo para os estudos de metalopeptidases presentes no VTs (CAJADO CARVALHO et al., 2014; VENANCIO et al., 2013), e Abz-FRK(Dnp)P-OH (4 $\mu \mathrm{M})$, peptídeo fluorescente especialmente desenhado para estudos com a carboxipeptidase ACE por apresentar o C- 
terminal livre (ARAUJO et al., 2000). O resultado encontra-se expresso na figura a seguir.
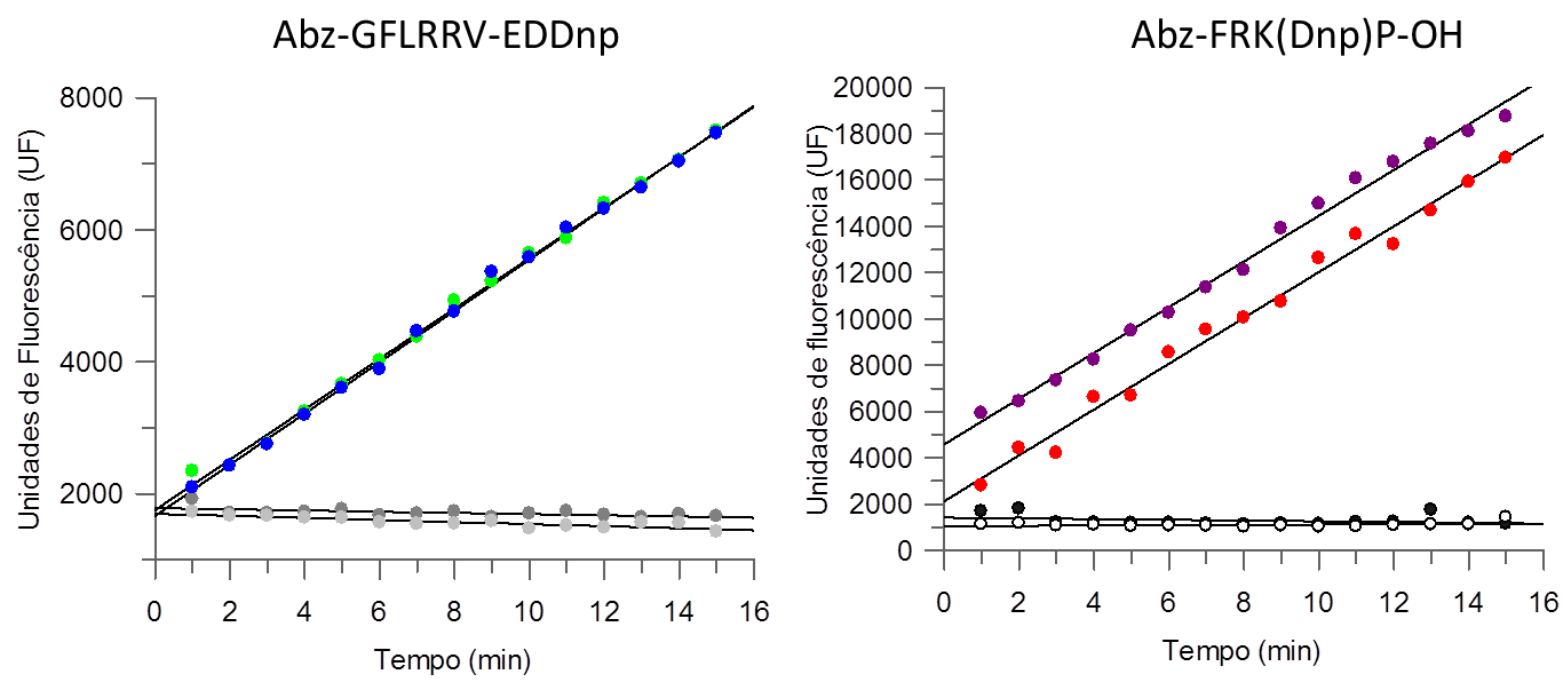

Figura 04 - Ensaio de atividade do veneno de Tityus serrulatus sobre os substratos AbzGFLRRV-EDDnp (esquerda, em azul e verde) e Abz-FRK(Dnp)P-OH (direita, rosa e roxo) utilizando o tampão Tris $100 \mathrm{mM}, \mathrm{NaCl} 50 \mathrm{mM}, 10 \mu \mathrm{M} \mathrm{ZnCl}_{2}, \mathrm{pH}$ 7,0. Os controles dos substratos (substrato com tampão) também estão representados em ambas as figuras (em cinza, à esquerda, e em preto e branco, à direita). Os ensaios foram realizados em duplicatas, as velocidades de hidrólise foram determinadas em fluorímetro Victor 3 (Perkin Elmer) e as análises feitas em software Grafit 5.0.

Como demonstra a Figura 04, o Abz-FRK(Dnp)P-OH foi clivado eficientemente pelo veneno total. O substrato Abz-GFLRRV-EDDnp já havia sido caracterizado como substrato para as metaloendopeptidases do VTs (CAJADO CARVALHO et al., 2014; VENANCIO et al., 2013) e utilizado rotineiramente no laboratório. Assim, como estes substratos permitem a clivagem por diferentes tipos de peptidases - Abz-GFLRRVEDDnp por endopeptidases e Abz-FRK(Dnp)P-OH por carboxipeptidases - ambos os substratos foram utilizados para os screening de atividade subsequentes.

\subsection{Ensaio de inibição do veneno total de $\underline{\text { Tityus serrulatus }}$}

A fim de se obter mais informações sobre as peptidases atuantes em cada substrato fluorescente, o VTs foi testado na presença de diversos inibidores utilizando os substratos fluorescentes Abz-FRK(Dnp)P-OH e Abz-GFLRRV-EDDnp. Foram utilizados inibidores sítio-específicos para serinopeptidases (PMSF) e para metalopeptidases (1,10-fenantrolina e EDTA), e inibidores seletivos para atividade ACE 
símile, captopril e Bj-PRO-10c (CAMARGO et al., 2012); para a enzima conversora de endotelina e neprilisina, o fosforamidon (KUKKOLA et al., 1995); e para neprilisina, tiorfan e [des-Arg ${ }^{1}$ ]-proctolin (DUZZI et al., 2016), tendo em vista que são enzimas que compartilham certos substratos como, por exemplo, a angiotensina I (RAWLINGS et al., 2010). O resultado é demonstrado na Figura 05.

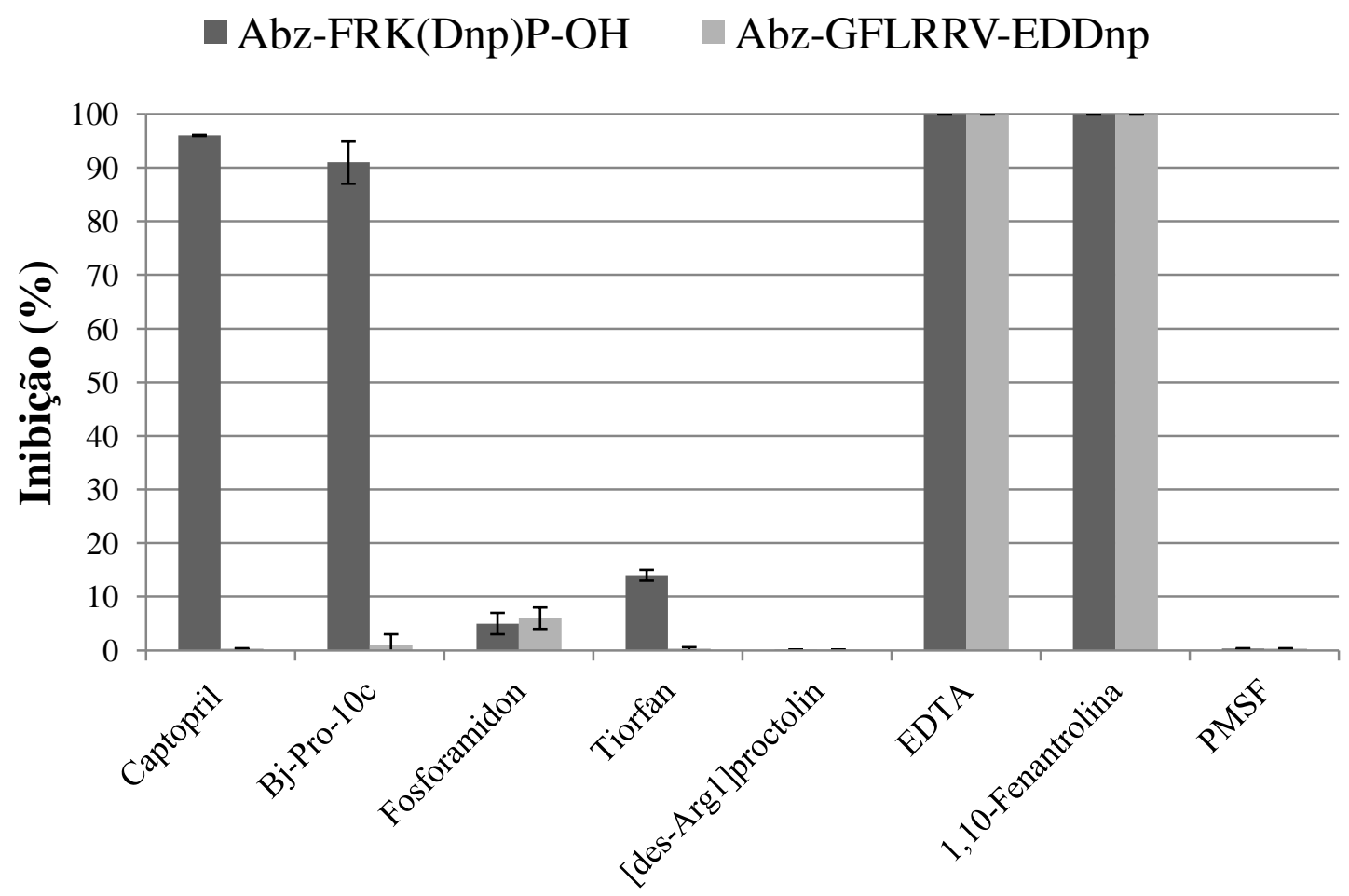

Figura 05 - Inibição das atividades do VTs sobre os substratos fluorescentes para carboxi- e endopeptidases. Captopril $(100 \mathrm{nM}), B j$-Pro-10c $(16 \mu \mathrm{M})$, tiorfan $(10 \mu \mathrm{M})$, fosforamidon $(10 \mu \mathrm{M})$, EDTA $(50 \mathrm{mM}), 1,10$-fenantrolina $(2 \mathrm{mM})$, PMSF $(2 \mathrm{mM})$ e [des-Arg ${ }^{1}$ ]-proctolin $(10 \mu \mathrm{M})$ foram testados com o veneno total de Tityus serrulatus $(1 \mu \mathrm{g})$ em ensaio fluorimétrico utilizando Abz-FRK(Dnp)P-OH (cinzaescuro) e Abz-GFLRRV-EDDnp (cinza-claro). As reações ocorreram em tampão $100 \mathrm{mM}$ Tris, $50 \mathrm{mM} \mathrm{NaCl}, 10 \mu \mathrm{M} \mathrm{ZnCl}$, $\mathrm{pH} \mathrm{7,0} \mathrm{a} 37{ }^{\circ} \mathrm{C}$. Os ensaios foram realizados em duplicata, as velocidades de hidrólise foram determinadas em fluorímetro Victor 3 (Perkin Elmer) e as análises feitas em software Grafit 5.

Como aponta a Figura 05, a 1,10-fenantrolina e o EDTA foram capazes de inibir $100 \%$ da atividade enzimática sobre ambos os substratos, enquanto que a hidrólise foi mantida na presença do PMSF, assim, pode-se concluir que somente metalopeptidases atuam nos substratos FRETs testados. Além disso, o VTs não tem sua atividade peptidásica reduzida sobre o substrato Abz-GFLRRV-EDDnp na presença do captopril, enquanto quando incubado com Abz-FRK(Dnp)P-OH, foi possível observar inibição 
quase total (96\%) da hidrólise do substrato pelo veneno em pequenas concentrações desde inibidor (100 nM). O peptídeo Bj-PRO-10c também foi capaz de inibir mais efetivamente a hidrólise de Abz-FRK(Dnp)P-OH (91\% de inibição) do que em relação a hidrólise do substrato Abz-GFLRRV-EDDnp (1\%). Em seguida, o fosforamidon inibiu fracamente o VTs sobre ambos os substratos, Abz-FRK(Dnp)P-OH (5\%) e AbzGFLRRV-EDDnp (6\%), ao passo que o tiorfan foi capaz de inibir parcialmente somente a clivagem de Abz-FRK(Dnp)P-OH (14\%). O peptídeo [des-Arg ${ }^{1}$ ]-proctolin não afetou a atividade proteolítica do veneno em nenhum dos substratos testados.

Em adendo, por conta da inibição significativa obtida pelo captopril, foi verificada a porcentagem de inibição deste inibidor sobre a hidrólise dos peptídeos biologicamente ativos relacionados à ACE humana (angiotensina I, bradicinina e hemopressina). A dinorfina 1-13 foi utilizada como controle negativo, tendo em vista que não houve inibição pelo captopril sobre o substrato fluorescente análogo (AbzGFLRRV-EDDnp). Os resultados estão representados na Tabela 04.

Tabela 04 - Inibição das peptidases do veneno de Tityus serrulatus na hidrólise de peptídeos biologicamente ativos utilizando os inibidores captopril e EDTA. Experimento realizado em cromatografia de fase reversa com coluna Restek C-18 em sistema de HPLC (Shimadzu).

Inibição da atividade de VTs (\%)

\begin{tabular}{crrr} 
Peptídeo & EDTA 50 $\mathbf{~ m M}$ & Captopril 100 $\mathbf{n M}$ & Captopril $\mathbf{1} \boldsymbol{\mu M}$ \\
\hline Angiotensina-I & $100 \pm 0$ & $8,2 \pm 4,0$ & $49,0 \pm 7,0$ \\
Bradicinina & $100 \pm 0$ & $36,0 \pm 4,0$ & $60,0 \pm 5,0$ \\
Dinorfina 1-13 & $100 \pm 0$ & $0,0 \pm 5,0$ & $2,0 \pm 4,0$ \\
Hemopressina & $100 \pm 0$ & $38,0 \pm 5,0$ & $9,0 \pm 4,0$ \\
\hline
\end{tabular}

O captopril foi seletivo para a inibição da hidrólise dos substratos relacionados à atividade ACE-like, tendo em vista que a hidrólise da dinorfina 1-13 não foi afetada, enquanto as clivagens da angiotensina I e bradicinina foram inibidas de acordo com o aumento da concentração deste inibidor. 
Apesar da hidrólise da hemopressina ter sido inibida pelo captopril, foi atingido um menor valor de porcentagem de inibição na presença da maior dose deste inibidor (1 $\mu \mathrm{M}$ ). Contudo, ao observar o perfil de hidrólise obtido em HPLC deste substrato (Figura 06), é possível notar que o pico correspondente ao fragmento PVNFKFL, produto esperado pela ação de peptidases ACE-símile (DALE et al., 2005), é totalmente inibido mesmo com $100 \mathrm{nM}$ de captopril. Assim, podemos concluir que a hemopressina é substrato tanto para as endopeptidases quanto para as carboxipeptidases presentes no VTs.



Figura 06 - Análise de hidrólise da hemopressina pelo VTs em cromatografia de fase reversa e inibição por captopril. (A) Hemopressina, $30 \mu \mathrm{M}$, sem veneno; (B) Hemopressina após 2 horas de incubação com o veneno de Tityus serrulatus $(1 \mu \mathrm{g})$, indicando os produtos de hidrólise; Clivagem de hemopressina pelo VTs na presença de $100 \mathrm{nM}$ (C) e $1 \mu \mathrm{M}$ (D) de captopril, indicando a não formação do pico PVNFKFL em ambas condições testadas. Experimento realizado em cromatografia de fase reversa com coluna Restek C-18 em sistema de HPLC (Shimadzu).

\subsection{Influência do íon cloreto na atividade da ACE-like do veneno de $\underline{\text { Tityus }}$ serrulatus}

Considerando que a ACE humana sofre influência positiva na presença de cloreto (YATES et al., 2014), foi realizado um experimento comparativo entre a hidrólise do substrato Abz-FRK(Dnp)P-OH pelo veneno total e pela ACE (Sigma) na presença de concentrações crescentes de $\mathrm{NaCl}$. O resultado pode ser observado na figura a seguir. 
A)

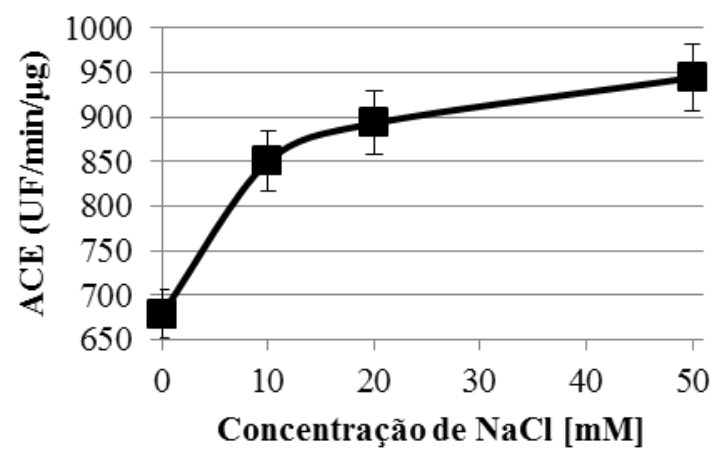

B)

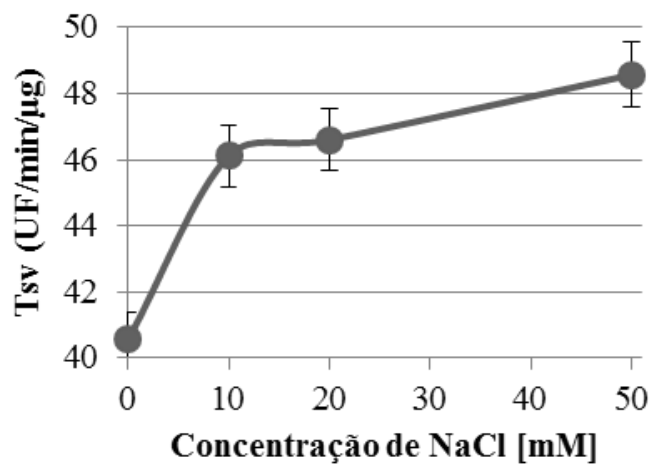

Figura 07 - Efeito da concentração de íons cloreto sobre (A) Enzima Conversora de Angiotensina I (Sigma) (B) veneno de Tityus serrulatus. Para ambos, a hidrólise sobre o substrato Abz-FRK(Dnp)P-OH foi determinada em tampão Tris 100 $\mathrm{mM}, \mathrm{ZnCl}_{2} 10 \mu \mathrm{M}$, com quatro concentrações de $\mathrm{NaCl}$ : zero, $10 \mathrm{mM}, 20 \mathrm{mM}$ e $50 \mathrm{mM}$. O resultado representa a média de dois experimentos independentes.

Como demonstrado, tanto para o veneno total quanto para a enzima conversora de angiotensina I comercial, as atividades foram positivamente afetadas com o aumento de concentrações de $\mathrm{NaCl}$. Na presença de $\mathrm{NaCl} 10 \mathrm{mM}$, o VTs e a ACE de pulmão de coelho demonstraram um aumento de $15 \%$ e $25 \%$ em suas atividades catalíticas, respectivamente, e na maior concentração testada $(50 \mathrm{mM})$ a hidrólise do AbzFRK(Dnp)P-OH pelo VTs aumentou mais de $35 \%$, e cerca de $46 \%$ para a ACE de mamífero.

\subsection{Análise do potencial neutralizante dos antivenenos comerciais sobre as hidrólises dos substratos fluorescentes e peptídeos bioativos pelo veneno total}

O ensaio de inibição da atividade proteolítica de $1 \mu \mathrm{g}$ de VTs por soroneutralização foi realizado primeiramente com o substrato Abz-GFLRRV-EDDnp utilizando os soros antiescorpiônico (SAE) e antiaracnídico (SAAr) (Figura 08). 


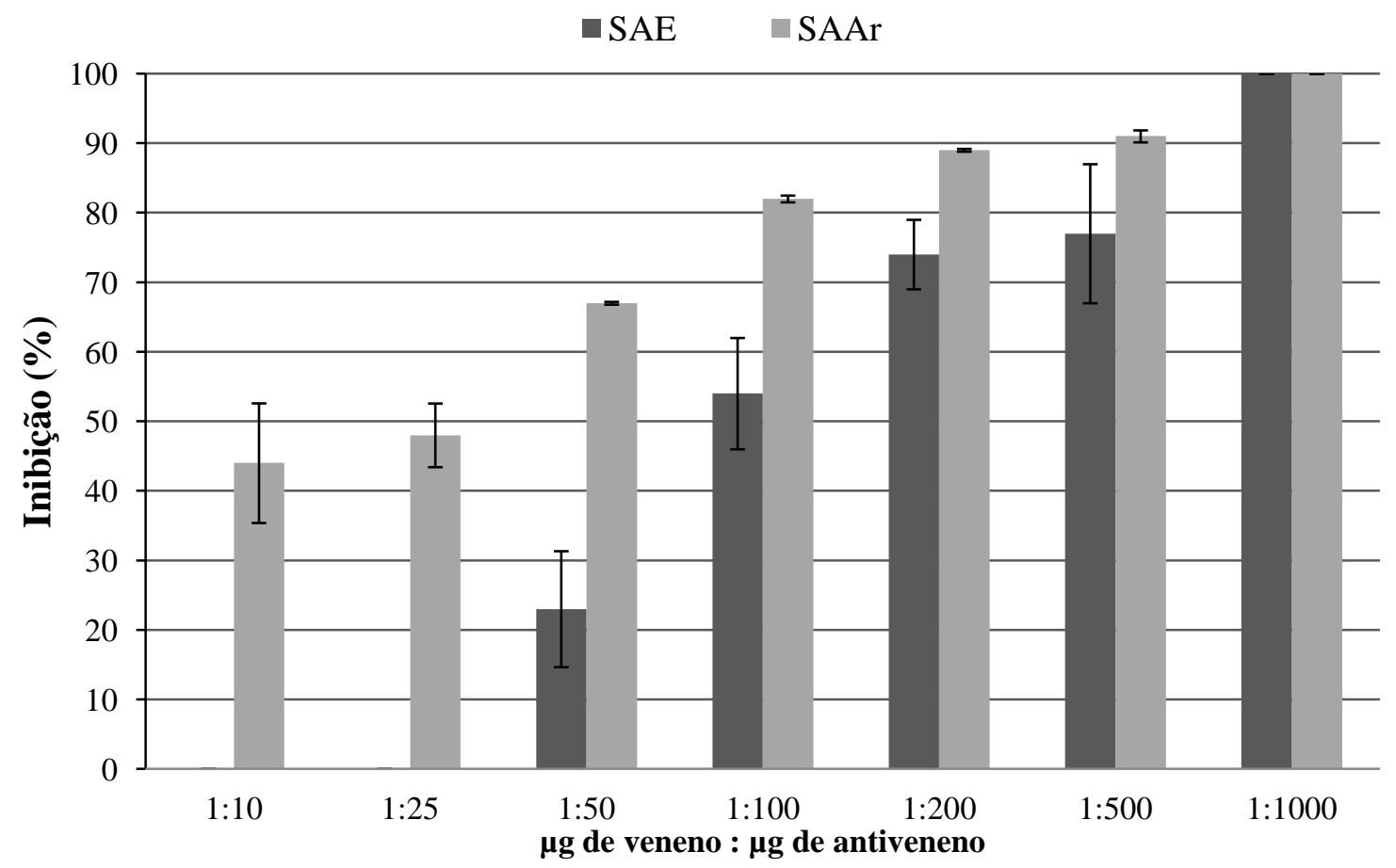

Figura 08 - Curva de inibição por soroneutralização com antivenenos comerciais utilizando o substrato Abz-GFLRRV-EDDnp e o veneno de T. serrulatus $(1 \mu \mathrm{g})$. O veneno foi previamente incubado durante 30 minutos à temperatura ambiente, com nove concentrações de antivenenos (relação massa veneno/massa antiveneno, em $\mu \mathrm{g}$ ): $1: 1 ; 1: 2 ; 1: 10 ; 1: 25 ; 1: 50 ; 1: 100 ; 1: 200 ; 1: 500$ e $1: 1000$, e o substrato foi adicionado na sequência. Doses abaixo de 1:10 não mostraram inibição e por isso foram excluídas do gráfico. O resultado é representativo de dois experimentos independentes, e expresso como a inibição da atividade peptidásica do veneno (\%). SAE $=$ soro antiescorpiônico e SAAr $=$ soro antiaracnídico. As velocidades de hidrólise foram determinadas em fluorímetro Victor 3 (Perkin Elmer) e as análises realizadas em software Grafit 5.0.

A Figura 08 mostra que o SAAr apresenta, no geral, maior porcentagem de inibição do que SAE, pois o soro antiaracnídico é capaz de inibir em doses anteriores (a partir de 1:10 relação massa veneno/massa antiveneno) do que o soro antiescorpiônico, que demonstra atividade inibitória somente a partir de 1:50. Ambos os antivenenos foram somente capazes de inibir totalmente a atividade enzimática sobre o substrato fluorescente na concentração 1:1000 e não foi observada nenhuma inibição em doses abaixo de 1:10.

Tendo em vista que o substrato fluorescente Abz-FRK(Dnp)P-OH mostrou ser alvo de diferente(s) enzima(s) em relação ao Abz-GFLRRV-EDDnp, o ensaio de inibição pelos antivenenos comerciais também foi realizado neste FRET. O resultado encontra-se expresso a seguir, na Figura 09. 


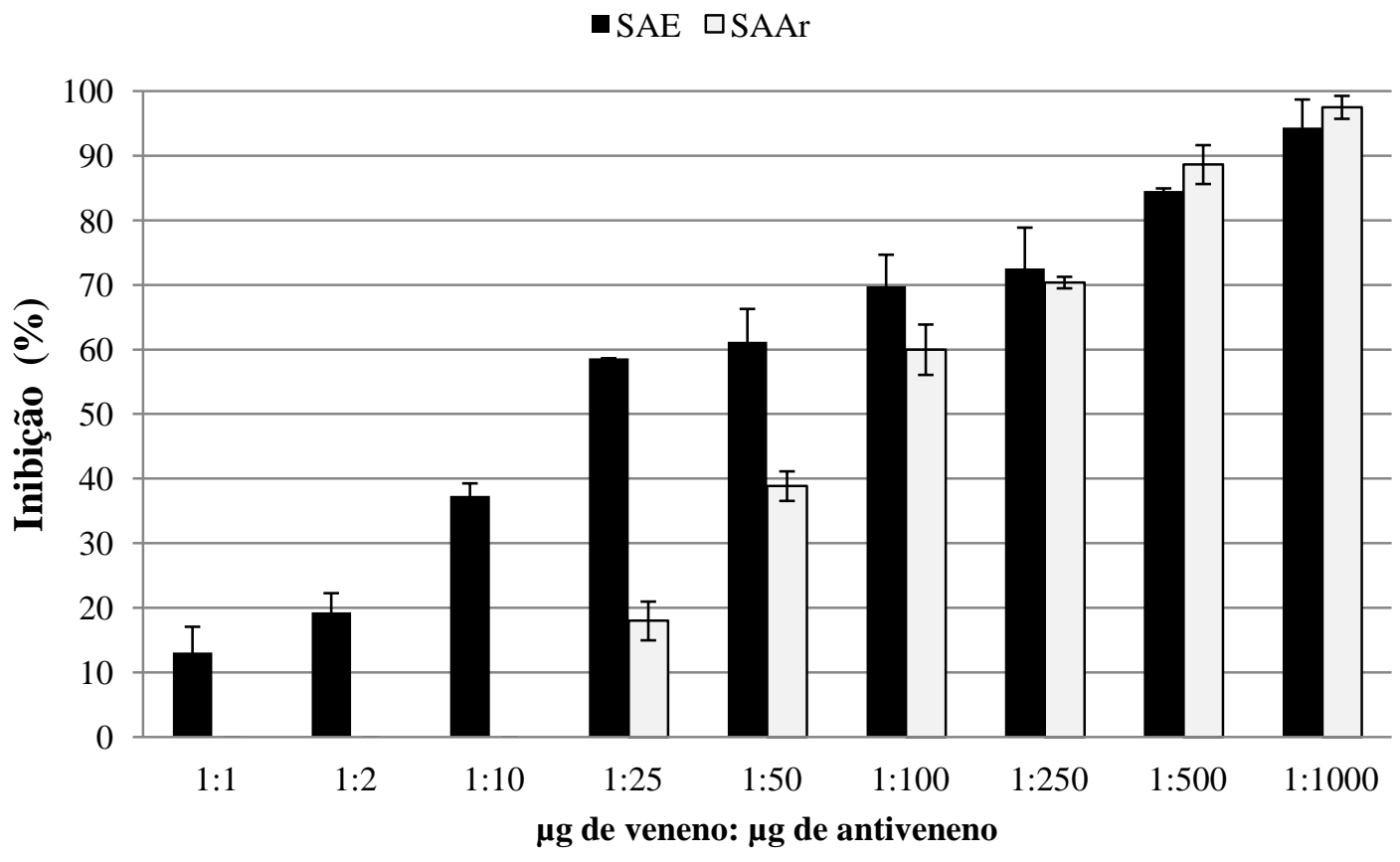

Figura 09 - Curva de inibição por soroneutralização com antivenenos comerciais utilizando o substrato Abz-FRK(Dnp)P-OH e o veneno de T. serrulatus $(1 \mu \mathrm{g})$. O veneno foi incubado durante 30 minutos à temperatura ambiente, com nove concentrações (relação massa veneno/massa antiveneno): $1: 1 ; 1: 2 ; 1: 10 ; 1: 25 ; 1: 50 ; 1: 100$; $1: 200 ; 1: 500$ e $1: 1000$, e o substrato foi adicionado na sequência. O resultado é representativo de dois experimentos independentes e expressa a inibição da atividade peptidásica do veneno $(\%) . \mathrm{SAE}=$ soro antiescorpiônico e $\mathrm{SAAr}=$ soro antiaracnídico. As velocidades de hidrólise foram determinadas em fluorímetro Victor 3 (Perkin Elmer) e as análises realizadas em software Grafit 5.0.

Para a atividade do VTs sobre Abz-FRK(Dnp)P-OH, o bloqueio iniciou-se logo na primeira dose de SAE utilizada mas, apesar disso, mesmo na maior dose utilizada (1:1000), a atividade proteolítica sobre esse substrato não foi completamente inibida por nenhum dos antivenenos (94\% de inibição por SAE e $97 \%$ por SAAr).

Em seguida, realizamos o ensaio de eficácia da neutralização do VTs pelos antivenenos (1:50 e 1:100) com os substratos selecionados (neuropeptídeo Y, peptídeo YY, hemopressina e polipeptídeo pancreático e dinorfina 1-13). O resultado pode ser observado na Figura 10. 


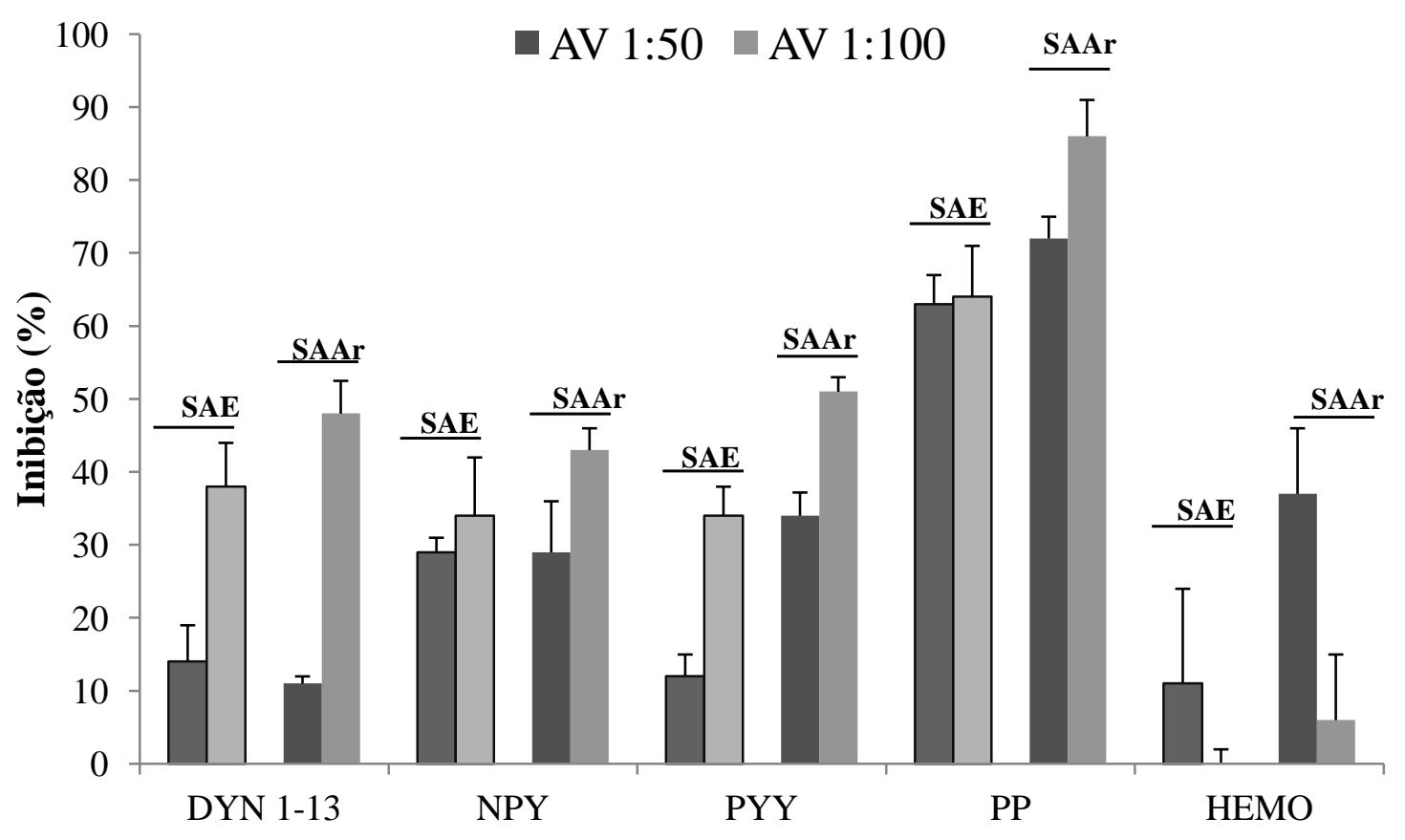

Figura 10 - Inibição de peptidases do veneno de Tityus serrulatus por soroneutralização utilizando os antivenenos comerciais utilizando como substratos peptídeos biologicamente ativos. Foram utilizados os seguintes substratos: dinorfina 1-13 (Dyn 1-13); neuropeptídeo Y (NPY); peptídeo YY (PYY); polipeptídeo pancreático (PP) e hemopressina (HEMO). O veneno de T. serrulatus $(1 \mu \mathrm{g})$ foi incubado durante 30 minutos à temperatura ambiente com doses de 1:50 e 1:100 de soro antiescorpiônico (SAE) ou soro antiaracnídico (SAAr). Os experimentos foram feitos em duplicata. Os resultados foram obtidos em cromatografia de fase reversa com coluna Restek C-18 em sistema de HPLC (Shimadzu).

A Figura 10 mostra que, para a maioria dos peptídeos, observou-se uma resposta de inibição proporcional ao aumento da dose de soro, com exceção da hemopressina. No geral, a neutralização pelo SAAr foi mais efetiva do que pelo SAE. A clivagem sobre o polipeptídeo pancreático (PP) foi a melhor neutralizada por ambos os antivenenos, atingindo $86 \%$ de inibição para SAAr e $64 \%$ para SAE na maior dose testada, e também em 1:50 (63\% de inibição por SAE e 72\% de inibição por SAAr). A atividade do veneno sobre a dinorfina 1-13 (Dyn 1-13) e o peptídeo YY (PYY) foram similarmente inibidas pelo SAE tanto na menor dose (12\% e $14 \%$, respectivamente) quanto na maior (38\% e 34\%, respectivamente), porém, o SAAr na dose de 1:50 atingiu melhores valores de inibição sobre a clivagem de PYY (34\%) do que para a hidrólise de Dyn 1-13 (11\%). No caso da clivagem de NPY, tanto o SAE e quanto o SAAr resultaram em valores de inibição similares em ambas as doses (29\% de inibição na dose de 1:50 para ambos os antivenenos, e 34\% por SAE e 43\% para SAAr na concentração 1:100). Por fim, a clivagem da hemopressina apresentou os piores valores de inibição do que em relação aos demais substratos e, curiosamente, a menor 
concentração de ambos os soros (11\% para SAE e 37\% para SAAr) atingiu melhores valores de bloqueio da atividade do que em relação à dose de 1:100, na qual a inibição foi praticamente ausente (SAE) ou muito baixa $(6 \%$ de bloqueio da atividade por SAAr).

Os resultados referentes à atividade metaloendopeptidásica descritos até o momento foram publicados na revista Toxinological Science em 2014 (CAJADO CARVALHO et al., 2014).

\subsection{Fracionamentos do veneno total: Purificação das metalopeptidases do VTs}

4.6.1 Purificação da enzima conversora de angiotensina I do veneno de Tityus serrulaus

4.6.1.1 Passo I: Cromatografia de troca aniônica

Após a caracterização dos dois substratos FRETs e dos peptídeos biologicamente ativos para serem utilizados em screening de atividade durante as etapas de purificação, o VTs foi submetido a uma cromatografia de troca aniônica utilizando a coluna de HPLC PA-DEAE (Shim-Pack) (Figura 11). A coleta inicial foi a partir de $50 \mathrm{mg}$ diluídos em $5 \mathrm{~mL}$ de tampão A (10 mg/mL).

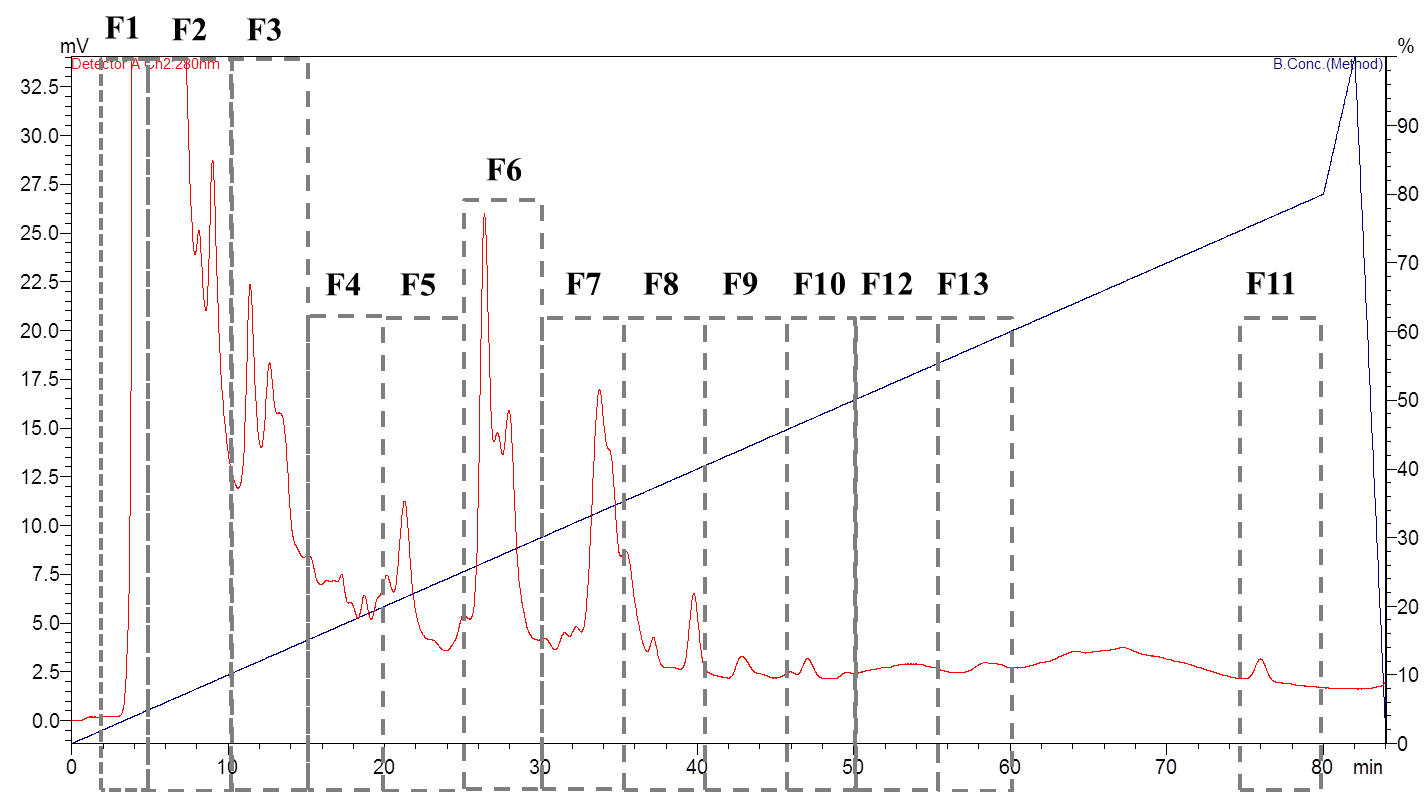

Figura 11 - Perfil cromatográfico do veneno total de T. serrulatus utilizando a coluna de troca aniônica para HPLC PA-DEAE (Shim-Pack) em sistema de HPLC (Shimadzu). A eluição foi feita sob fluxo $5 \mathrm{~mL} / \mathrm{min}$ utilizando tampão A (Tris $20 \mathrm{mM}, \mathrm{NaCl} 20$ mM, pH 8,2) e tampão B (tampão A com adição de 500 mM, NaCl pH 8,2), sendo o gradiente de $0-80 \%$ B em 80 minutos (linha azul). 
A Figura 11 mostra que foram coletadas onze frações do veneno total obtidas em intervalo de 5 em 5 minutos, com exceção da fração F11.

Após a coleta, as frações da DEAE tiveram suas concentrações dosadas pelo método de Bradford e foram analisadas quanto a sua atividade peptidásica utilizando o substrato fluorescente e a hemopressina. A Tabela 05 mostra as velocidades de hidrólise obtidas sobre o substrato fluorescente Abz-FRK(Dnp)P-OH e sobre a hemopressina. A hemopressina foi selecionada para o screening de atividade dentre os peptídeos biologicamente ativos, uma vez que a atividade específica do VTs é mais elevada neste substrato do que em relação a angiotensina I e bradicinina (Tabela 05) no tampão 2. Além disso, a hemopressina é 100 vezes melhor hidrolisada pela ACE humana quando comparada com a angiotensina I (RIOLI et al., 2003).

Tabela 05 - Atividade específica do veneno total de Tityus serrulatus (VTs) e das frações coletadas da troca aniônica (DEAE) sobre a hidrólise de hemopressina e AbzFRK(Dnp)P-OH. Os resultados foram obtidos em cromatografia de fase reversa com coluna Restek C-18 em sistema de HPLC (Shimadzu) para a hemopressina. Para o substrato fluorescente Abz-FRK(Dnp)P-OH, as hidrólise foram determinadas em fluorímetro Victor 3 (Perkin Elmer) e as análises realizadas em software Grafit 5.0.

\begin{tabular}{c|c|c}
\hline \multicolumn{1}{c|}{ Amostra } & $\begin{array}{c}\text { Hidrólise de Hemopressina } \\
(\boldsymbol{\mu M} / \boldsymbol{\mu g} / \mathbf{m i n})\end{array}$ & $\begin{array}{c}\text { Hidrólise de Abz-FRK(Dnp)P- } \\
\text { OH (UF/min) }\end{array}$ \\
\hline VTs & $\mathbf{0 , 1 8 0}$ & $\mathbf{1 0 0 2}$ \\
\hline DEAE-F1 & $\mathbf{0 , 0 9 7}$ & $\mathbf{2 1 5}$ \\
\hline DEAE-F2 & 0,041 & 6 \\
\hline DEAE-F3 & S/A & 11 \\
\hline DEAE-F4 & S/A & 16 \\
\hline DEAE-F5 & S/A & 11 \\
\hline DEAE-F6 & S/A & 8 \\
\hline
\end{tabular}

É possível observar claras diferenças entre as frações testadas. A fração F1 foi cerca de 200 vezes mais ativa para a hidrólise do substrato Abz-FRK(Dnp)P-OH do que em relação as outras frações. Para o substrato natural, as frações F1 e F2 foram capazes de hidrolisar a hemopressina, enquanto as demais frações não tem atividade sobre este 
peptídeo. Como é possível observar na Figura 11, é importante destacar que a fração F1 não ficou retida na coluna cromatográfica utilizada.

A Figura 12 demonstra o perfil de hidrólise da fração F1 sobre os substratos angiotensina I (Painel A), selecionado por ser alvo de interesse biológico e clivada pela enzima conversora de angiotensina I, e hemopressina (Painel B), a qual foi bem hidrolisada pelo veneno total e reconhecida por ser um bom substrato para a ACE (Figura 06).

A

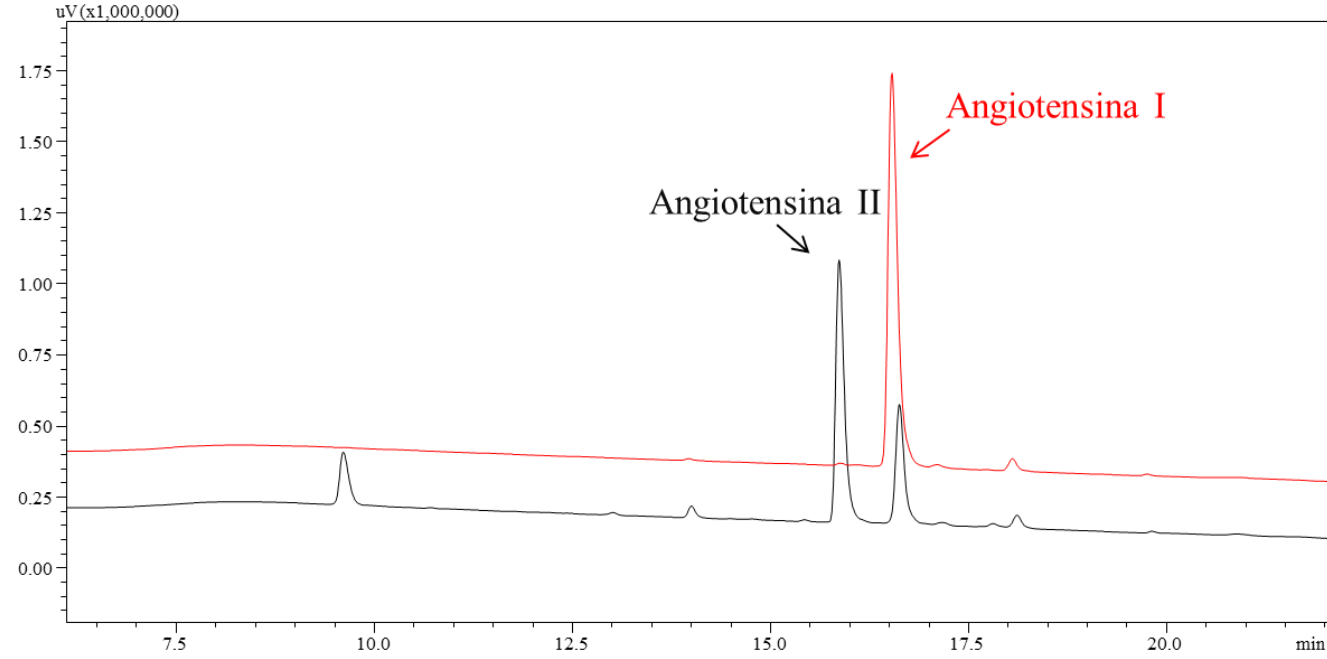

B

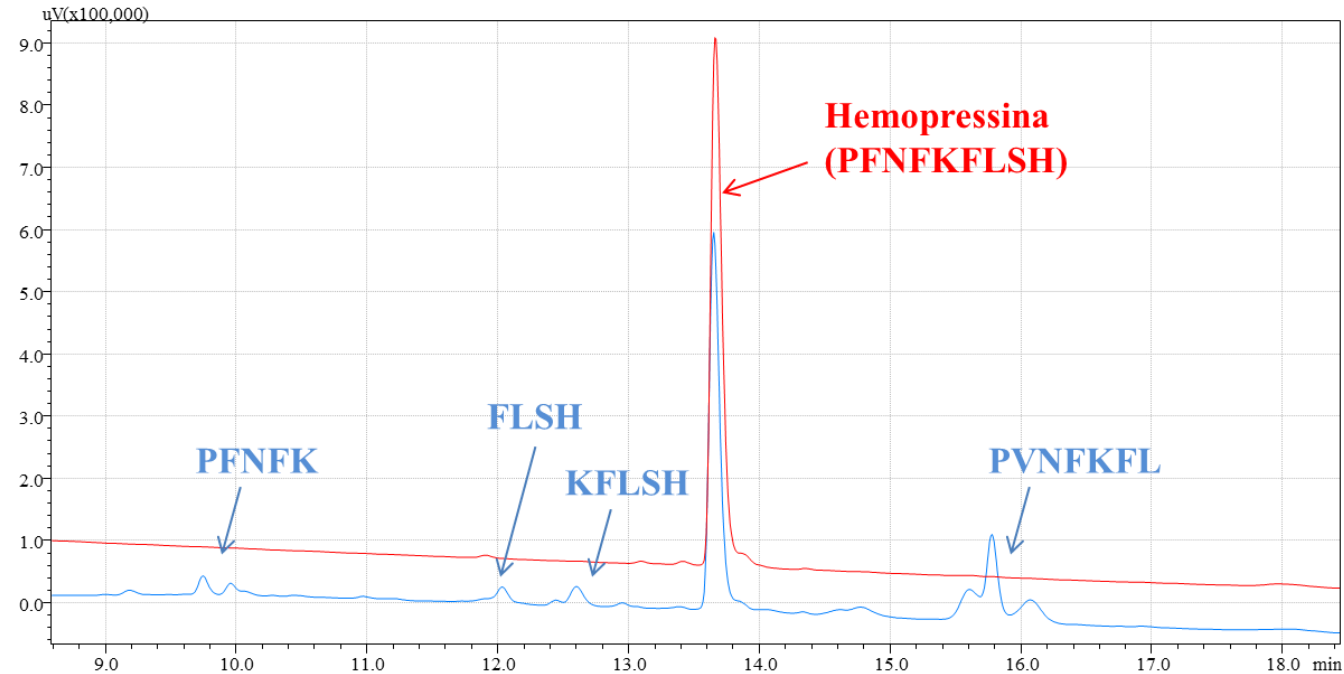

Figura 12 - Ação peptidásica da fração F1. (A) Angiotensina I (incubação overnight) e (B) Hemopressina, (incubação de 2 horas). Os resultados foram obtidos em cromatografia de fase reversa utilizando coluna C-18 no sistema HPLC (Shimadzu). 
A partir da Figura 12, observa-se a formação de picos similares obtidos quando foi utilizado o veneno total (Figura 06) e a fração F1. Além dos picos mais hidrofílicos PVNFK, KFLSH e FLSH, observa-se a formação da fração PVNFKFL, o que indica a remoção dos aminoácidos Ser-His do N-terminal por uma dipeptilcarboxipeptidase. Para a angiotensina I, é possível observar a formação de angiotensina II e outros dois picos de hidrólise mais hidrofílicos.

Após selecionar a fração com melhor atividade carboxipeptidásica (F1), foi realizada a retirada de sal e concentração das amostras utilizando membrana de corte molecular de $3 \mathrm{kDa}$ (Amicon Ultra-15 Centrifugal Filter Devices), além da troca do tampão de eluição da DEAE para Tris $100 \mathrm{mM}, \mathrm{NaCl} 50 \mathrm{mM}, \mathrm{ZnCl}_{2} 10 \mu \mathrm{M}, \mathrm{pH}$ 7,0, visando a manutenção da atividade ACE-like. A fração foi analisada em gel 13\% corado por Coomassie Blue Coloidal. O resultado pode ser observado na Figura 13.

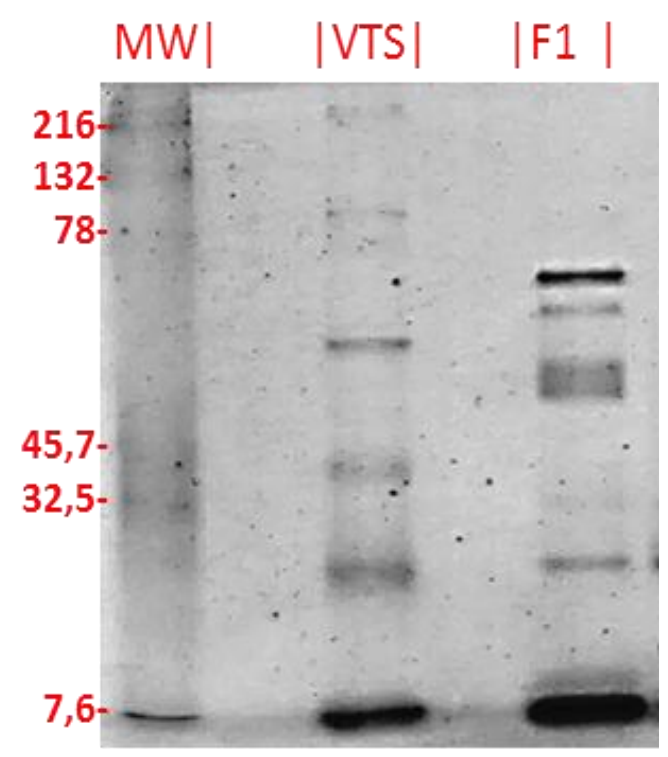

Figura 13 - Gel SDS-PAGE de poliacrilamida a 13\% com coloração Coomassie Blue Coloidal do veneno total de $T$. serrulatus (VTs) e da fração F1 proveniente da cromatografia de troca iônica, todos em condições não redutoras. O marcador molecular utilizado foi Kaleidoscope Prestained Standards (7,6-216 kDa).

O gel de poliacrilamida demonstrou um perfil bem complexo e, por conta das bandas apresentarem diferentes massas moleculares, a etapa de purificação seguinte foi a cromatografia de exclusão molecular. 
4.6.1.2 Cromatografia de exclusão molecular (Gel-Filtração)

A cromatografia de exclusão molecular decorreu em sistema HPLC (Shimadzu) utilizando a coluna Diol-300 (Shim-pack). A fração F1 foi aplicada e suas subfrações coletadas manualmente (Figura 14).

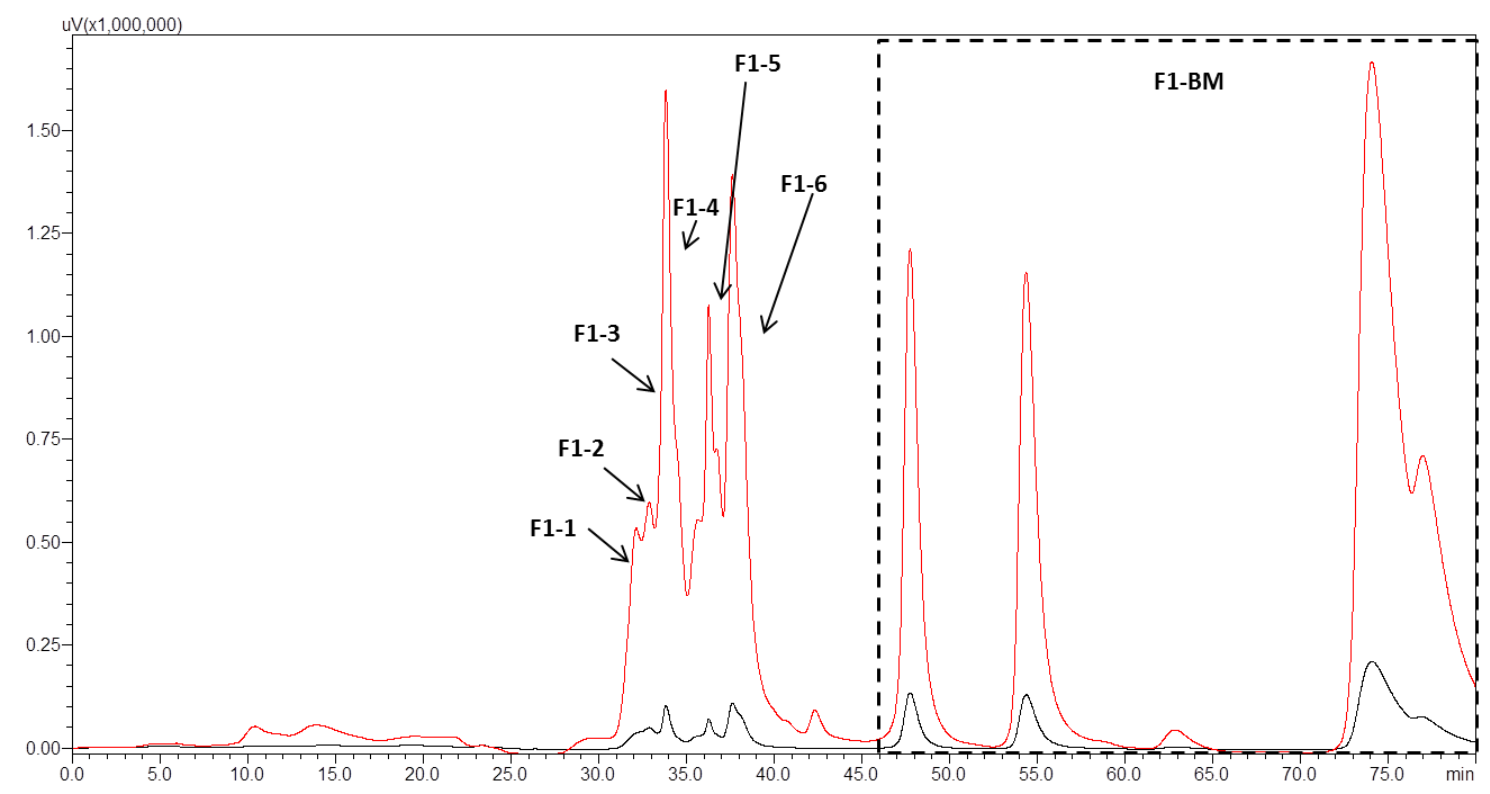

Figura 14 - Perfil cromatográfico da fração F1 em gel-filtração utilizando a coluna Diol-300. A amostra foi eluída sob fluxo $0,5 \mathrm{~mL} / \mathrm{min}$ utilizando tampão sulfato de sódio 200 $\mathrm{mM}$, fosfato de sódio $10 \mathrm{mM} \mathrm{pH} \mathrm{7,0,} \mathrm{em} 80$ minutos. Em vermelho, detecção a 214 $\mathrm{nm}$ e em preto, detecção em $280 \mathrm{~nm}$.

Como demonstra a Figura 14, a fração F1 em gel-filtração resultou em sete novas frações principais, sendo que na última foram reunidos os picos de componentes com menor massa molecular.

Após a coleta, as subfrações foram primeiramente quantificadas pelo método de Bradford e posteriormente submetidas à screening de atividade com o substrato fluorescente Abz-FRK(Dnp)P-OH. Além disso, o tampão foi novamente trocado para Tris $100 \mathrm{mM}, \mathrm{NaCl} 50 \mathrm{mM}, \mathrm{ZnCl}_{2} 10 \mu \mathrm{M}, \mathrm{pH}$ 7,0 utilizando uma membrana de corte molecular de $3 \mathrm{kDa}$, tendo em vista a sensibilidade desta enzima quanto ao tampão de estoque. Os ensaios cinéticos e o perfil eletroforético das frações estão expressos na figura a seguir. 

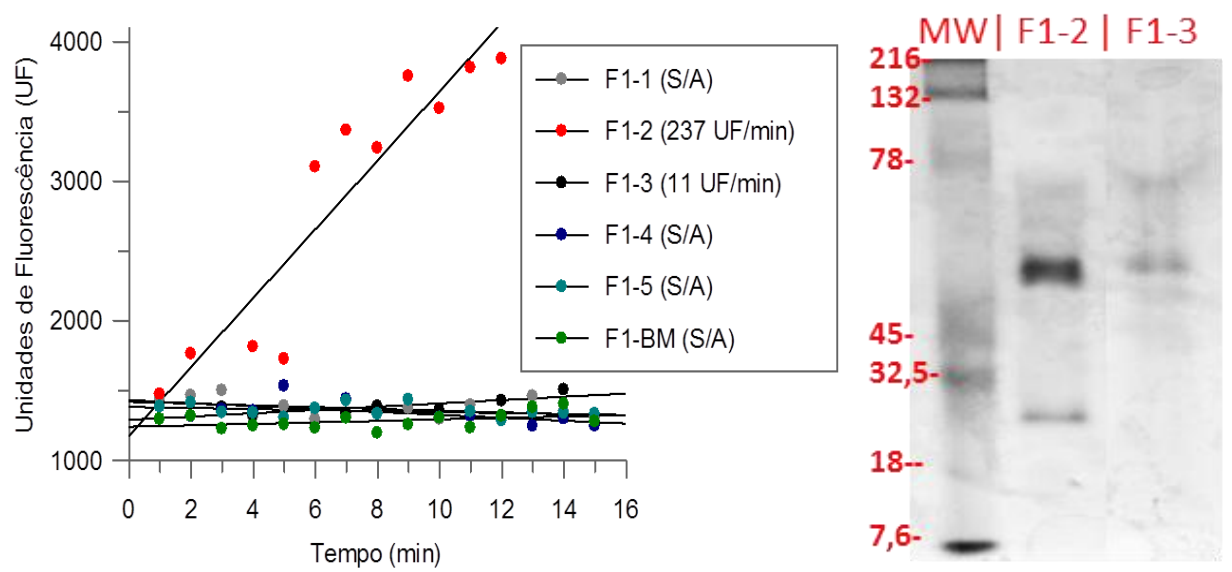

Figura 15 - Resultados das subsfrações de F1 obtidas em gel-filtração: À esquerda, screening de atividade das subfrações de F1 pós gel-filtração $(5 \mu \mathrm{g})$ utilizando o substrato Abz-FRK(Dnp)P-OH $(5 \mu \mathrm{M})$ e à direita, gel de SDS-PAGE $13 \%$, em condições não redutoras, corado por prata. $\mathrm{S} / \mathrm{A}=$ sem atividade. $\mathrm{O}$ marcador molecular utilizado foi Kaleidoscope Prestained Standards (7,6-216 kDa).

Como mostra a Figura 15, após a gel-filtração, as frações que apresentaram atividade proteolítica foram F1-2 e F1-3. O gel demonstra ao menos três bandas proteicas principais em F1-2 e duas em F1-3, indicando a necessidade de uma próxima etapa de purificação.

\subsubsection{Cromatografia de troca catiônica}

Por se tratar de uma fração proveniente da $\mathrm{F} 1$, a qual não interagiu com a coluna aniônica, a amostra F1-2 da gel-filtração foi submetida à troca catiônica. A coluna utilizada foi PA-CM (Shim-pack), sendo o tampão A composto de Tris $20 \mathrm{mM}, \mathrm{NaCl} 20$ mM, pH 7,0 e o tampão B composto pelo tampão A com adição de $0,5 \mathrm{mM}$ de $\mathrm{NaCl}$. A eluição teve duração de 80 minutos a $0,4 \mathrm{~mL} / \mathrm{min}$. A Figura 16 mostra o resultado. 




Figura 16 - Cromatografia de troca catiônica da fração F1-2 utilizando a coluna de HPLC PACM (Shim-Pack). A eluição foi feita sob fluxo $0,4 \mathrm{~mL} / \mathrm{min}$ em tampão A (Tris 20 $\mathrm{mM}, \mathrm{NaCl} 20 \mathrm{mM}, \mathrm{pH} 7,0$ ) e tampão B (tampão A com adição de $\mathrm{NaCl} 500 \mathrm{mM}$, $\mathrm{pH} 7,0$ ), sendo o gradiente (linha azul) de 0-30\% B em 40 minutos, $30-80 \% \mathrm{~B}$ em 10 minutos e 80-100\% B em 5 minutos. Detecção em $280 \mathrm{~nm}$.

As frações foram coletadas, concentradas em membrana de corte molecular de 3 $\mathrm{kDa}$ a $4{ }^{\circ} \mathrm{C}$ e, afim de manter a atividade proteolítica, e o tampão foi novamente trocado para Tris $100 \mathrm{mM}, \mathrm{NaCl} 50 \mathrm{mM}, \mathrm{ZnCl}_{2} 10 \mu \mathrm{M}, \mathrm{pH}$ 7,0. Em seguida, as amostras foram quantificadas pelo método de Bradford e testadas com o substrato Abz-FRK(Dnp)P-OH e angiotensina I. O perfil eletroforético da amostra com melhor atividade em SDSPAGE $13 \%$ foi realizado (Figura 17). 

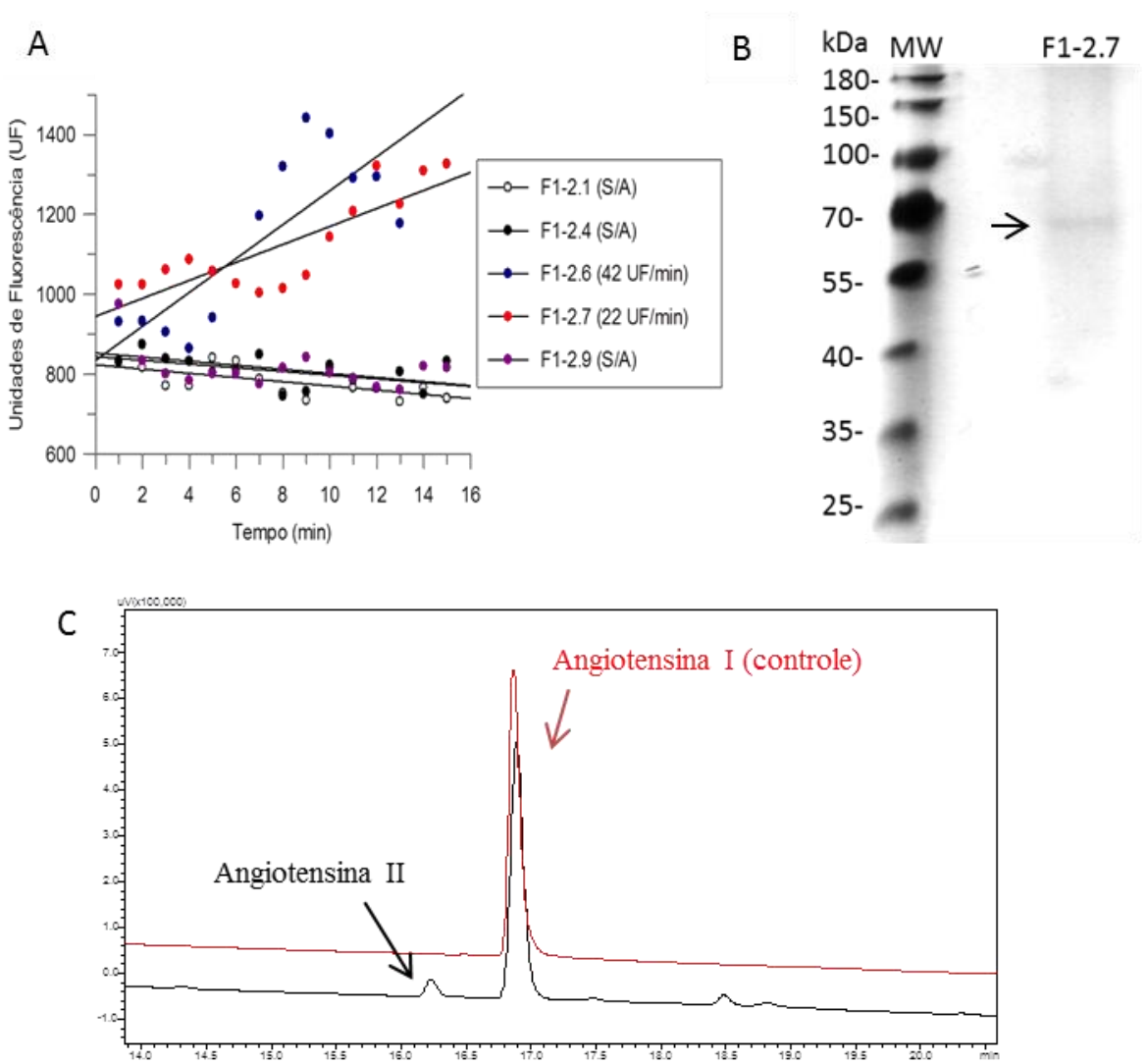

Figura 17 - Análise das subfrações de F1-2 obtidas na cromatografia de troca catiônica - (A) Screening fluorimétrico de atividade enzimática usando o substrato AbzFRK(Dnp)P-OH, apontando atividade principalmente em F1-2.6 (500 ng) e F1-2.7 (500 ng), (B) gel de poliacrilamida 13\%, demonstrando uma banda fraca em F12.7, em condições não redutoras; (C) Conversão de angiotensina I em angiotensina II pela fração F1-2.7 (aproximadamente 100 ng) após incubação overnight.

Como mostra a Figura 17, após a troca catiônica, as frações F1-2.6 e F1-2.7 foram as únicas capazes de clivar o substrato fluorescente Abz-FRK(Dnp)P-OH, além de realizar a conversão de angiotensina I em angiotensina II, mimetizando a atividade da enzima conversora de angiotensina I humana. O gel de poliacrilamida $13 \%$ revelou a uma banda fraca em F1-2.7 de aproximadamente $70 \mathrm{kDa}$, indicando a finalização da purificação.

A banda do gel de SDS-PAGE foi recortada, tripsinizada, e submetida ao espectrômetro de massas Orbitrap do Laboratório Especial de Toxinologia Aplicada (LETA) do Instituto Butantan. Os resultados foram analisados no software PEAKS 7.5. Para tal, foram selecionadas como modificações pós traducionais (PTM) a carbaminometilação de cisteínas, como modificação fixa, e como variável, a oxidação dos resíduos de metionina e a deamidação de asparagina e glutamina, por conta do tratamento utilizado na extração da banda do gel. 
Para a análise de sequenciamento da banda que corresponde à proteína com atividade similar a ACE, foi montado um banco de dados com sequências obtidas no UNIPROT (restrição para o gênero Tityus), sendo adicionadas as sequências de ACEs de T. serrulatus, T. bahiensis e T. obscurus obtidas por análise transcriptômica pelos colaboradores Dra. Ursula Castro de Oliveira e Dr. Inácio Junqueira de Azevedo, do Laboratório Especial de Toxinologia Aplicada do Instituto Butantan, pois se tratavam de sequências inéditas e ainda não encontradas em outros bancos de dados disponíveis. $\mathrm{O}$ resultado está representado na Figura 18.

A

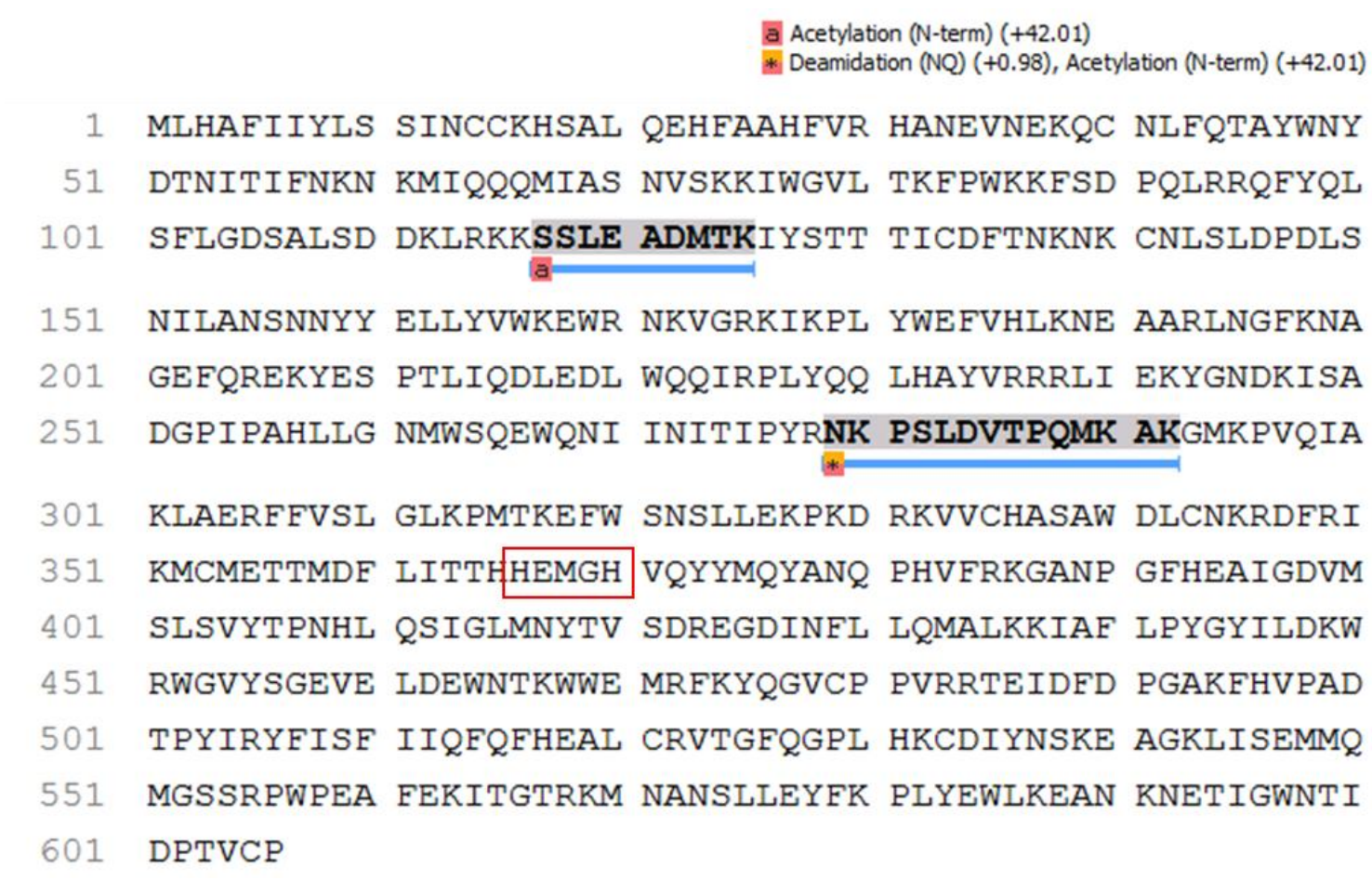


Figura 18 - Resultado da banda de F1-2.7 - Identificação por espectrometria de massas da enzima conversora de angiotensina-I similar a peptidase transcrita em Tityus serrulatus analisada em software PEAKS 7.5, com cobertura de 2\% da molécula. (A) Peptídeos resultantes da digestão in gel da banda de $70 \mathrm{kDa}$ marcados em azul na sequência primária da enzima, onde a consenso de metalopeptidases está destacado em vermelho (FDR< 1\%); (B) Espectros anotados dos dois peptídeos únicos encontrados. 
Para a fração F1-2.7, foram identificados dois peptídeos únicos da sequência da enzima conversora de angiotensina I do veneno de Tityus serrulatus, com índice de falsas descobertas (FDR) menor que 1\%. Por conta disso, esta molécula foi nomeada neste trabalho como serACE-like. O peso molecular predito de $72 \mathrm{kDa}$ para esse transcrito está de acordo com a banda referente à ACE I do VTs (Figura 17).

Tendo em vista que sequências similares à enzima conversora de angiotensina I estão presentes em outros transcritos provenientes de glândulas de veneno de escorpiões brasileiros do gênero Tityus, um alinhamento entre essas sequências foi realizado, sendo comparadas suas porcentagens de similaridades e identidades (Tabela 06). Em adendo, as sequências de ACE-like de escorpiões foram também comparadas com a estrutura primária da ACE testicular humana, considerando que esta molécula possui massa molecular similar, em torno de $70 \mathrm{kDa}$ (HAGAMAN et al., 1998).

Tabela 06 - Comparativo de identidade (branco) e similaridade (cinza) de estrutura primária dos transcritos de ACEs do veneno de T. serrulatus, T. bahiensis, e T. obscurus e da ACE testicular humana.

\begin{tabular}{lrccc} 
& $\begin{array}{l}\text { testicularACE } \\
\text { Homo sapiens } \\
\text { (AAA60611.1) }\end{array}$ & $\begin{array}{l}\text { T. serrulatus } \\
\text { (TserSP00939) }\end{array}$ & $\begin{array}{l}\text { T. bahiensis } \\
\text { (JAG85170) }\end{array}$ & $\begin{array}{l}\text { T. obscurus } \\
\text { (Tobs01141) }\end{array}$ \\
$\begin{array}{l}\text { testicularACE Homo sapiens } \\
\text { (AAA60611.1) }\end{array}$ & & $39,18 \%$ & $23,12 \%$ & $39,18 \%$ \\
$\begin{array}{l}\text { T. serrulatus (TserSP00939) } \\
\text { T. bahiensis (JAG85170) }\end{array}$ & $46,39 \%$ & & $67,21 \%$ & $90,34 \%$ \\
T obscurus (Tobs01141) & $28,16 \%$ & $67,34 \%$ & & $61,22 \%$ \\
\hline
\end{tabular}

A Tabela 06 demonstra alta identidade entre as ACEs dos venenos de $T$. serrulatus, T. bahiensis e T. obscurus, com mais de $67 \%$ dos aminoácidos idênticos. Em termos de similaridade, todas as sequências apresentam grau de similaridade acima de $46 \%$ entre si, indicando uma possível aproximação em termos funcionais.

Por conta de valores relevantes de identidade e similaridade, a sequências de ACE dos escorpiões brasileiros do gênero Tityus foram alinhadas com a sequência da ACE humana testicular (Homo sapiens [AAA60611.1]) (Figura 19). 


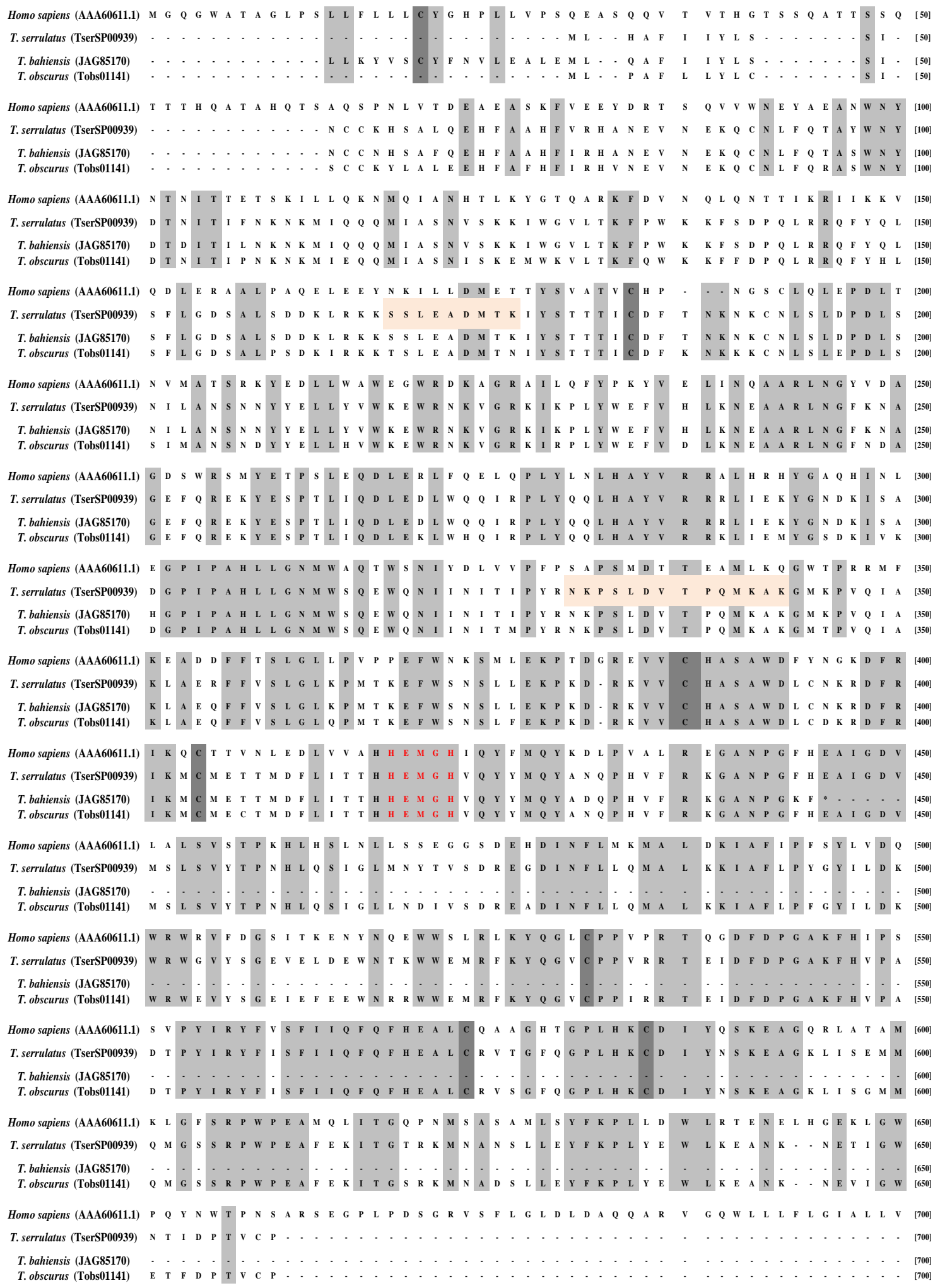

Homo sapiens (AAA60611.1)

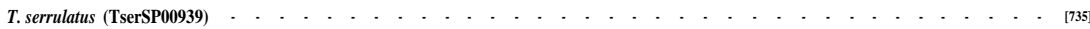

T. bahiensis (JAG85170)

Figura 19 - Alinhamento das sequências primárias das enzimas conversoras de angiotensina I das espécies Homo sapiens (AAA60611.1); Tityus serrulatus (Tser01365); Tityus bahiensis (Tbah00054); Tityus obscurus (Tobs01411). As análises foram realizadas no software Mega 7 utilizando a ferramenta MUSCLE (MUltiple Sequence Comparison by Log-Expectation). Em cinza estão marcadas as regiões 
conservadas, em cinza-escuro as cisteínas; em vermelho, o sítio de ligação com o zinco com assinatura de metalopeptidase HEMGH, e em laranja, os peptídeos encontrados em espectrometria de massas.

Como resultado do alinhamento, é possível notar a conservação de várias regiões, em especial, cisteínas localizadas na mesma posição e o sítio catalítico com aminoácidos idênticos (HEMGH), o que é um forte indício para uma atividade similar.

Os resultados referentes à purificação e caracterização por bioinformática da serACE-like descritos até este momento encontram-se publicados na revista Toxins (Anexo I).

4.6.1.4 Caracterizações bioquímicas da enzima conversora de angiotensina I-like purificada do VTs

\subsection{Determinação dos parâmetros cinéticos de serACE-like}

As constantes cinéticas de ACE-like na hidrólise de Abz-FRK(Dnp)P-OH foram obtidas em fluorímetro utilizando o tampão de trabalho Tris $100 \mathrm{mM}, \mathrm{NaCl} 50 \mathrm{mM}$, $\mathrm{ZnCl}_{2} 10 \mu \mathrm{M}, \mathrm{pH}$ 7,0. O resultado pode ser observado na Figura 20.

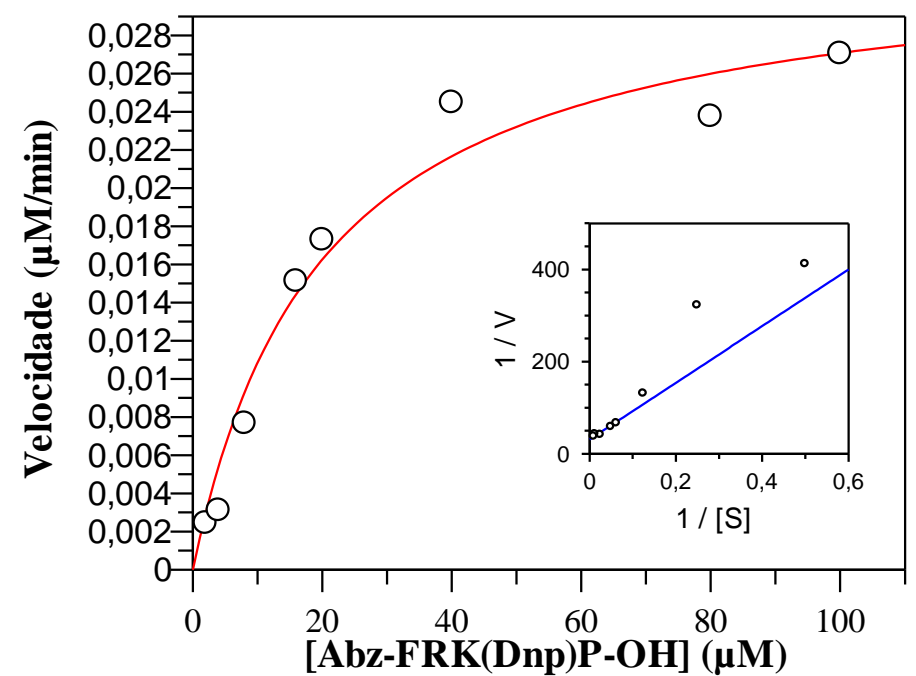

\begin{tabular}{cccc}
\hline & \multicolumn{3}{c}{ serACE-like $(\mu \mathrm{M} / \mathrm{min})$} \\
\hline & $\mathbf{K}_{\boldsymbol{m}}(\boldsymbol{\mu M})$ & $\mathbf{k}_{\text {cat }}\left(\mathbf{s}^{-\mathbf{1}}\right)$ & $\mathbf{k}_{\text {cat }} / \mathbf{K}_{\boldsymbol{m}}\left(\mathbf{s}^{\mathbf{- 1}} / \boldsymbol{\mu M}\right)$ \\
Abz-FRK(Dnp)P-OH & $19,97 \pm 4,65$ & $76,941 \pm 6,155$ & 3,853 \\
\hline
\end{tabular}

Figura 20 - Determinação das constantes cinéticas para a hidrólise do substrato fluorescente Abz-FRK(Dnp)P-OH em tampão Tris 100 mM, NaCl 50 mM, ZnCl $10 \mu \mathrm{M}, \mathrm{pH}$ 7,0 , utilizando a serACE-like do veneno do escorpião Tityus serrulatus. O 
resultado representa a média das triplicatas, e o valor de $\mathrm{K}_{m}$ foi obtido no software Grafit 5.0.

Como resultado, é possível observar que a serACE-like hidrolisou o substrato com um alto valor de $\mathrm{K}_{m}$ (aproximadamente $20 \mu \mathrm{M}$ ), mas também apresentou um alto valor de $\mathrm{k}_{\text {cat }}$ (cerca de $\left.77 \mathrm{~s}^{-1}\right)$. Assim, a constante de especificidade $\left(\mathrm{k}_{\text {cat }} / \mathrm{K}_{m}\right)$ foi relativamente baixa $\left(3,8 \mathrm{~s}^{-1} / \mu \mathrm{M}\right)$.

\subsection{Determinação das condições ideais do tampão de trabalho de serACE-like}

A influência do $\mathrm{pH}$ na atividade de serACE-like foi avaliada no intervalo entre pH 5,0 e 10,0. O resultado encontra-se expresso na figura a seguir.

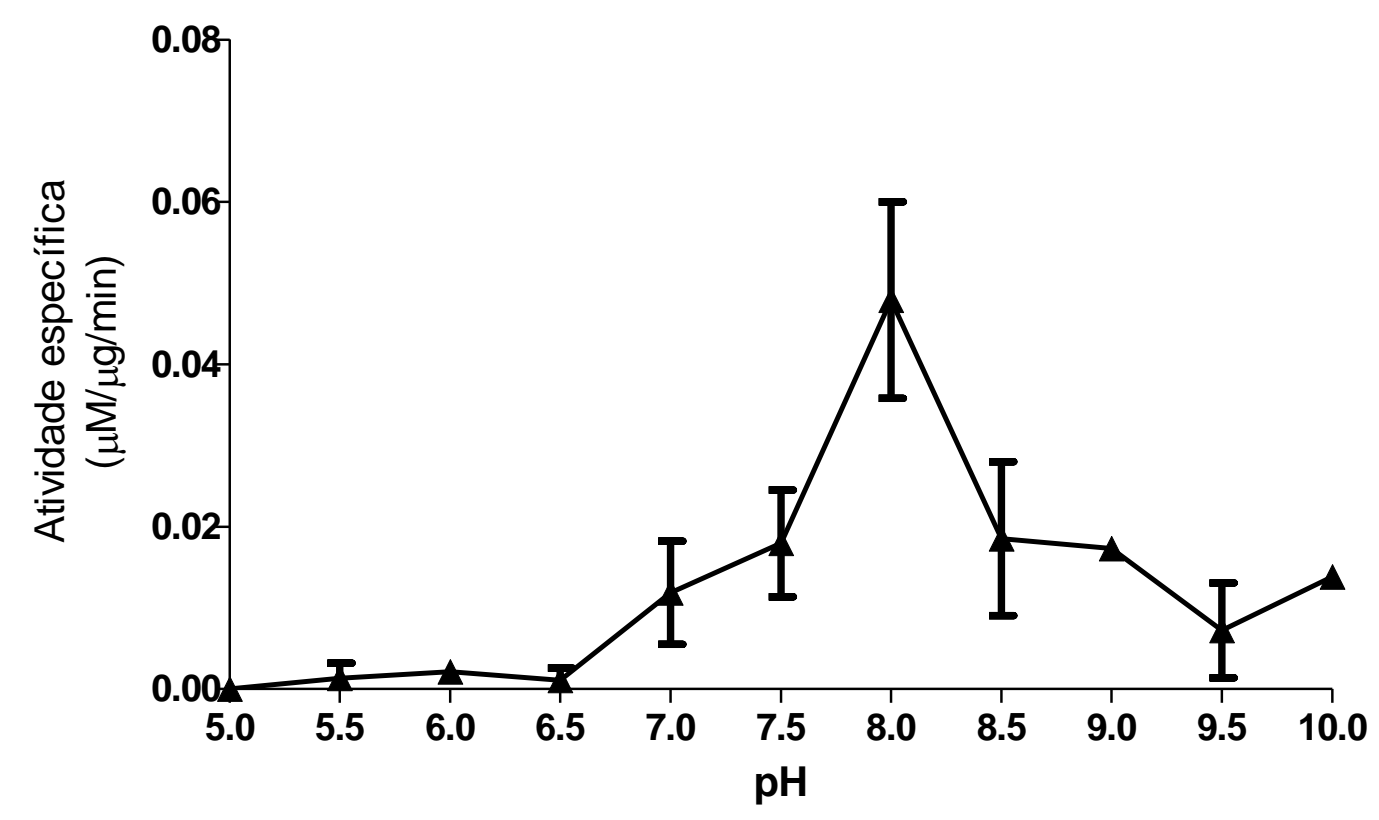

Figura 21 - Influência do pH na atividade peptidásica de serACE-like (500 ng). Os sais utilizados foram; fosfato de sódio ( $\mathrm{pH} 5,0$ - 7,5); bórax-ácido bórico ( $\mathrm{pH} \mathrm{8,0} \mathrm{-}$ 9,0) e bórax- $\mathrm{NaOH}$ (pH 9,5-10). A atividade proteolítica específica foi monitorada durante 15 minutos utilizando o substrato Abz-FRK(Dnp)P-OH (4 $\mu \mathrm{M})$. Experimento realizado em triplicata, e velocidades calculadas no software Grafit 5.0. Os gráficos foram construídos no software GraphPad Prism 5.0.

Como é possível observar, a serACE-like apresenta baixa atividade hidrolítica em meio ácido, sendo que não foi detectada atividade em $\mathrm{pH}$ 5,0. É possível observar aumento gradativo de acordo com a alcalinização do tampão de trabalho, apresentando um pico ótimo em $\mathrm{pH} 8,0$.

A influência da temperatura na atividade hidrolítica de serACE-like também foi avaliada entre $22^{\circ} \mathrm{C} \mathrm{e} 42{ }^{\circ} \mathrm{C}$ (Figura 22). 


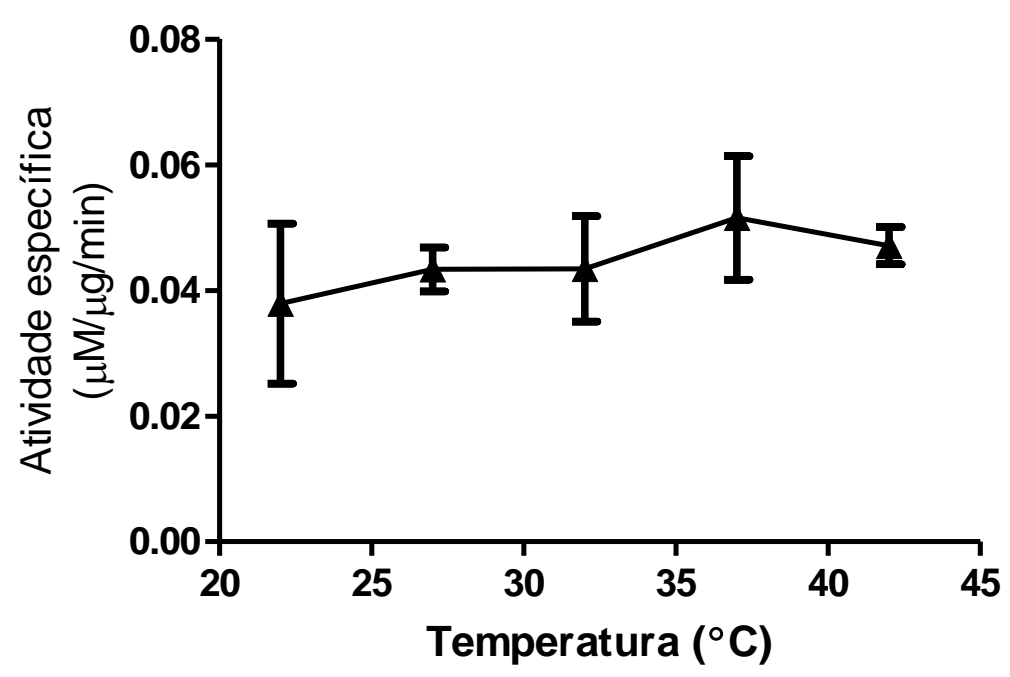

Figura 22 - Influência da temperatura na atividade de serACE-like (500 ng) do veneno de Tityus serrulatus em intervalo de $5{ }^{\circ} \mathrm{C}$ entre $22{ }^{\circ} \mathrm{C}$ e $42{ }^{\circ} \mathrm{C}$. A atividade proteolítica específica foi monitorada em fluorímetro Victor 3 (Perkin Elmer) durante 30 minutos. A peptidase foi pré-incubadas durante 15 minutos na temperatura desejada antes da adição do substrato. As atividades específicas $(\mu \mathrm{M} / \mu \mathrm{g} / \mathrm{min})$ foram calculadas no software Grafit 5.0 e os gráficos construídos no software GraphPad Prism 5.0. O experimento realizado em triplicata.

Para serACE-like, foi possível observar que a temperatura tem pouca influência na hidrólise do substrato. Em geral, a velocidade de hidrólise do substrato AbzFRK(Dnp)P-OH se manteve constante no intervalo testado.

\subsubsection{Purificação das metalloserrulases 3 e 4}

\subsubsection{Passo I: Cromatografia de troca aniônica}

Prosseguindo a purificação das demais peptidases de interesse, o fracionamento também se deu inicialmente pela mesma cromatografia utilizada para a purificação da ACE-símile. Ou seja, em cromatografia de troca aniônica utilizando a coluna de HPLC PA-DEAE (Shim-Pack) a partir de VTs na concentração de $10 \mathrm{mg} / \mathrm{mL}$ diluído em tampão A (Tris $20 \mathrm{mM}, \mathrm{NaCl} 20 \mathrm{mM}, \mathrm{pH}$ 8,2). Para uma melhor compreensão dos resultados, optamos pela reapresentação do perfil cromatográfico obtido com esta coluna (Figura 11). 


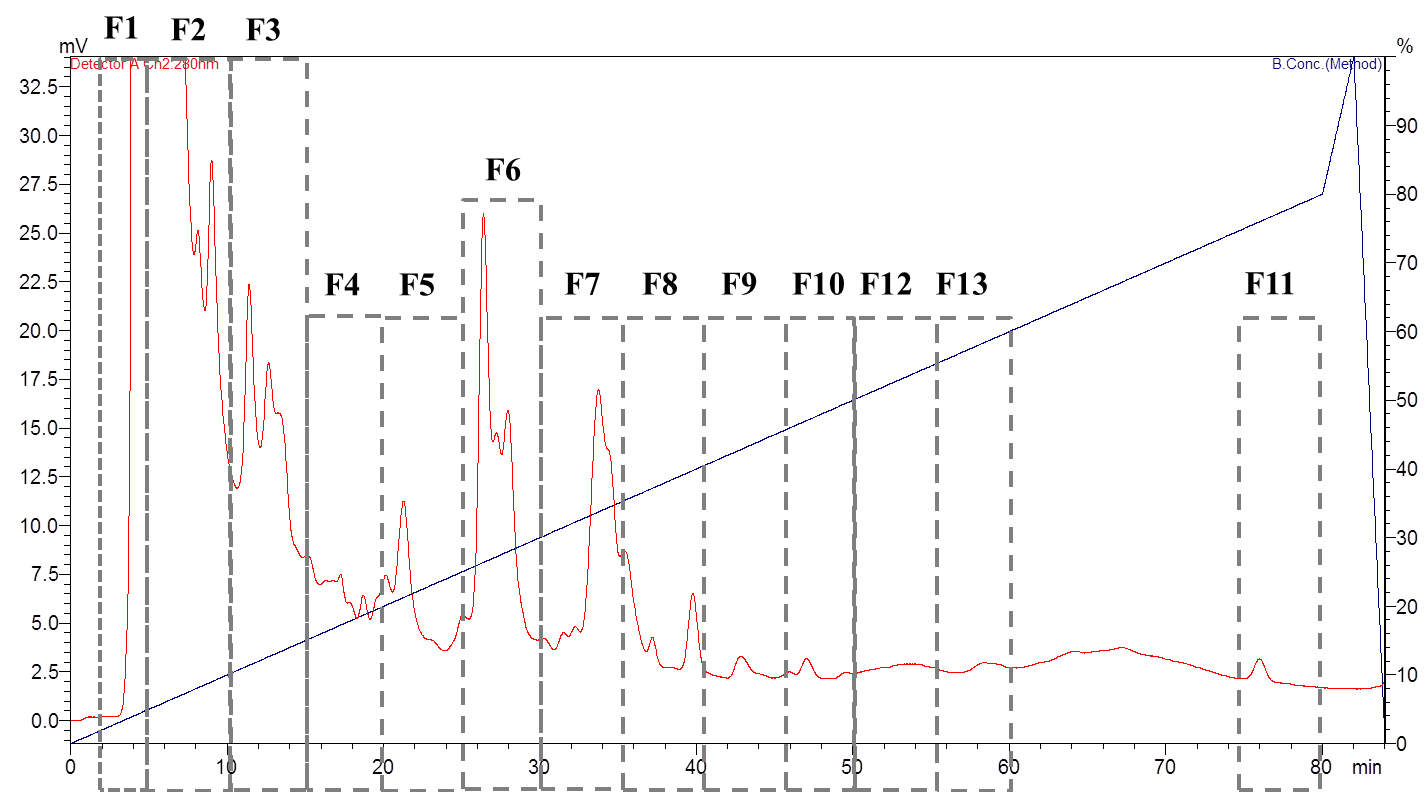

Figura 11 - Perfil cromatográfico do veneno total de T. serrulatus utilizando a coluna de troca aniônica para HPLC PA-DEAE (Shim-Pack) em sistema de HPLC (Shimadzu). A eluição foi feita sob fluxo $5 \mathrm{~mL} / \mathrm{min}$ utilizando tampão A (Tris $20 \mathrm{mM}, \mathrm{NaCl} 20$ mM, pH 8,2) e tampão B (tampão A com adição de $500 \mathrm{mM}, \mathrm{NaCl}$ pH 8,2), sendo o gradiente de $0-80 \%$ B em 80 minutos (linha azul).

Como demonstrado anteriormente, onze frações foram coletadas em intervalo de 5 em 5 minutos, com exceção da fração F11.

Como dito anteriormente, após a coleta as frações tiveram suas concentrações proteicas determinadas pelo método de Bradford. Para o screening de atividade das endopeptidases, as frações da DEAE foram analisadas quanto a sua velocidade de hidrólise sobre os substratos Abz-GFLRRV-EDDnp e dinorfina 1-13 (Tabela 07).

Tabela 07 - Atividade específica do veneno de Tityus serrulatus (VTs) e das frações coletadas da troca aniônica (DEAE) na hidrólise de dinorfina 1-13 obtidos em coluna de C18 no sistema HPLC (Shimadzu) de fase reversa, e na clivagem do substrato fluorescente Abz-GFLRRV-EDDnp, a qual foi determinada em fluorímetro Victor 3 (Perkin Elmer) e as análises realizadas em software Grafit 5.0.

\begin{tabular}{c|c|c}
\hline Amostra & $\begin{array}{c}\text { Hidrólise de Dinorfina 1-13 } \\
(\mu \mathrm{M} / \mu \mathrm{g} / \mathrm{min})\end{array}$ & $\begin{array}{c}\text { Hidrólise de Abz-GFLRRV-EDDnp } \\
(\mathrm{UF} / \mathrm{min})\end{array}$ \\
\hline VTs & $\mathbf{0 , 2 9}$ & $\mathbf{3 8 4 , 5}$ \\
\hline DEAE-F1 & S/A & S/A \\
\hline
\end{tabular}




\begin{tabular}{l|l|l}
\hline DEAE-F2 & 0,260 & 14 \\
\hline DEAE-F3 & 1,000 & 72 \\
\hline DEAE-F4 & 1,429 & 64 \\
\hline DEAE-F5 & 0,440 & 78 \\
\hline DEAE-F6 & 0,900 & 37 \\
\hline
\end{tabular}

Os valores mais expressivos de velocidades de hidrólise do substrato AbzGFLRRV-EDDnp foram observados nas frações F3 (72 UF/min) e F5 (78 UF/min). As frações subsequentes (F7 em diante) não foram capazes de clivar ou hidrolisaram fracamente o substrato testado e, por isso, não foram selecionadas para as próximas etapas de purificação.

A dinorfina 1-13 foi bem hidrolisada por todas as frações, com destaque para F3, F4 e F5, exceto pela F1, na qual não foi detectada atividade peptidásica neste substrato. Os produtos formados por cada fração são também diferenciados, sendo assim, a Figura 23 representa os perfis cromatográficos das frações pós-DEAE hidrolisando a dinorfina 1-13, em comparação com o veneno total. 
A

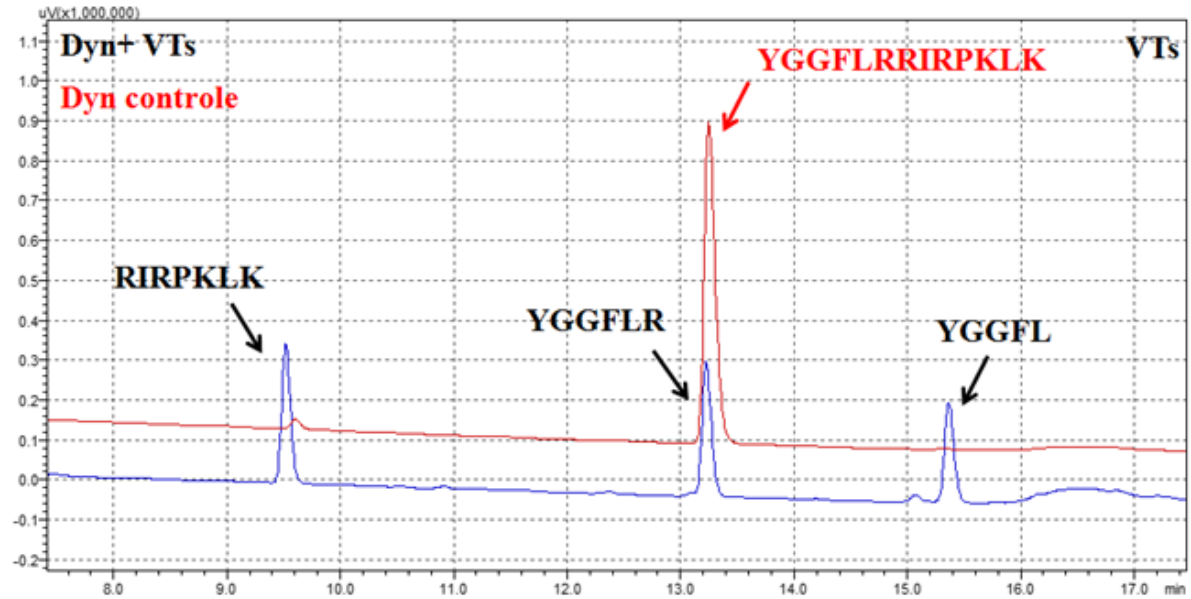

B
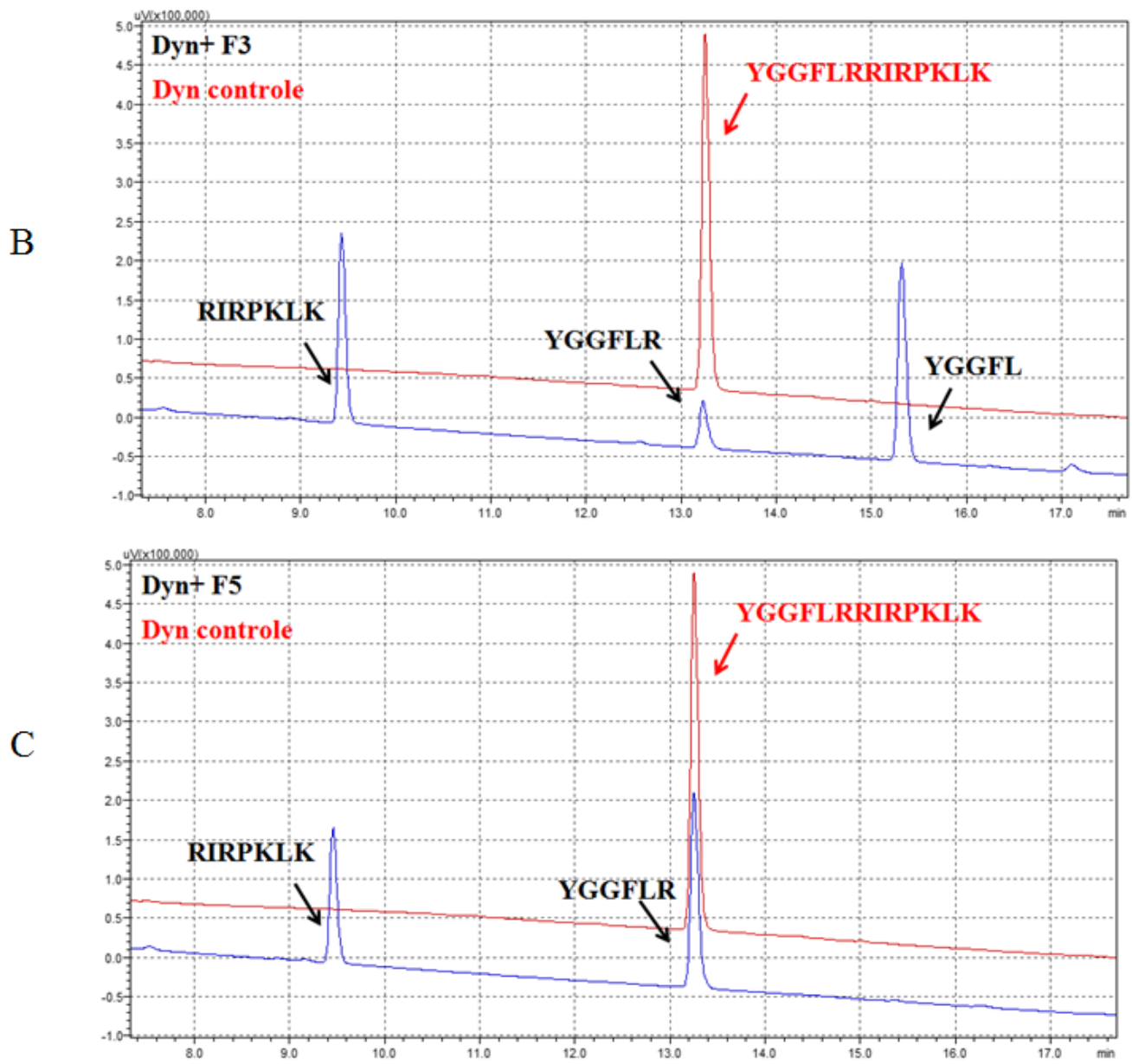

Figura 23 - Ação do veneno total e das frações da DEAE sobre dinorfina 1-13. (A) Veneno total; (B) fração F3; (C) fração F5. Os resultados foram obtidos por cromatografia de fase reversa em coluna de C-18 (Restek) no sistema HPLC (Shimadzu).

Para dinorfina 1-13, a fração F3 hidrolisou os substratos da mesma maneira que o veneno total, ocorrendo a liberação de Leu-encefalina (YGGFL). A fração F2 também manteve o perfil de clivagem no HPLC do veneno total, contudo com menor atividade (resultado não mostrado). Para a fração F5, foi possível observar um perfil diferenciado 
da hidrólise da Dyn 1-13, onde não há formação de Leu-encefalina (somente YGGFLR// RIRPKLK), mesmo após a hidrólise total do peptídeo. O mesmo padrão de hidrólise obtido com a F5 foi observado nas frações F4 e F6, contudo, com atividades específicas menores (resultados não mostrados).

As frações subsequentes (F7 em diante) não foram capazes de clivar ou hidrolisaram fracamente a dinorfina 1-13 e, por isso, não foram selecionadas para serem purificadas.

As frações provenientes da DEAE (F2 - F5) foram analisadas em SDS-PAGE $13 \%$ corado por prata em condições não redutoras. Para tal, foi realizada a retirada de sal e concentração das amostras utilizando membrana de corte molecular de $3 \mathrm{kDa}$ (Amicon Ultra-15 Centrifugal Filter Devices), além da dosagem por método de Bradford. O resultado pode ser observado na Figura 24.

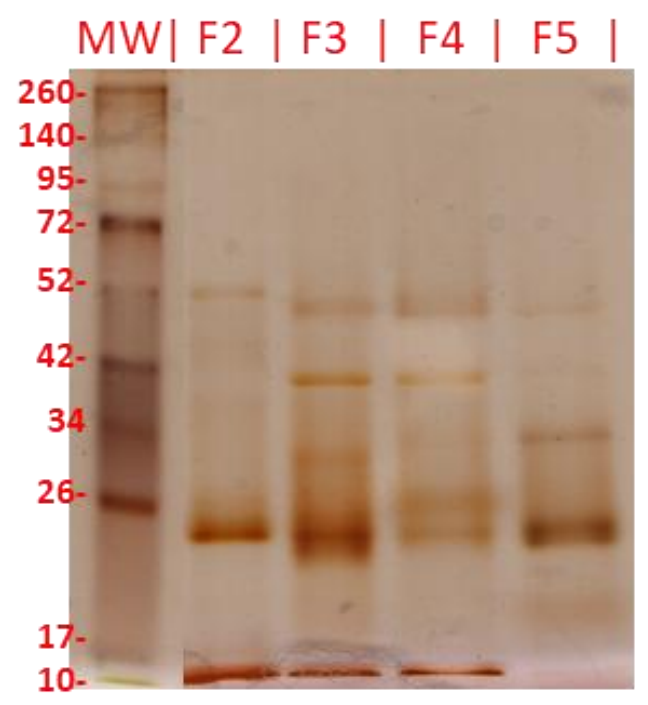

Figura 24 - SDS-PAGE a 13\% com coloração por prata das frações do veneno de T. serrulatus após a cromatografia de troca iônica. A figura mostra o perfil eletroforético do veneno total (VTs) e das frações F2, F3, F4 e F5, todos em condições não redutoras.

Por conta de apresentarem padrões de clivagem diferentes sobre a dinorfina 113 (liberação de Leu-encefalina para F3 ou ausência de formação deste peptídeo por F5), prosseguimos com a purificação de ambas as frações utilizando uma coluna de gelfiltração. 
4.6.2.2 Cromatografia de exclusão molecular (Gel-filtração)

As frações F3 e F5 foram fracionadas separadamente utilizando a coluna Diol300 (Shim-pack) em sistema HPLC (Shimadzu). O perfil cromatográfico de F3 encontra-se na Figura 25.

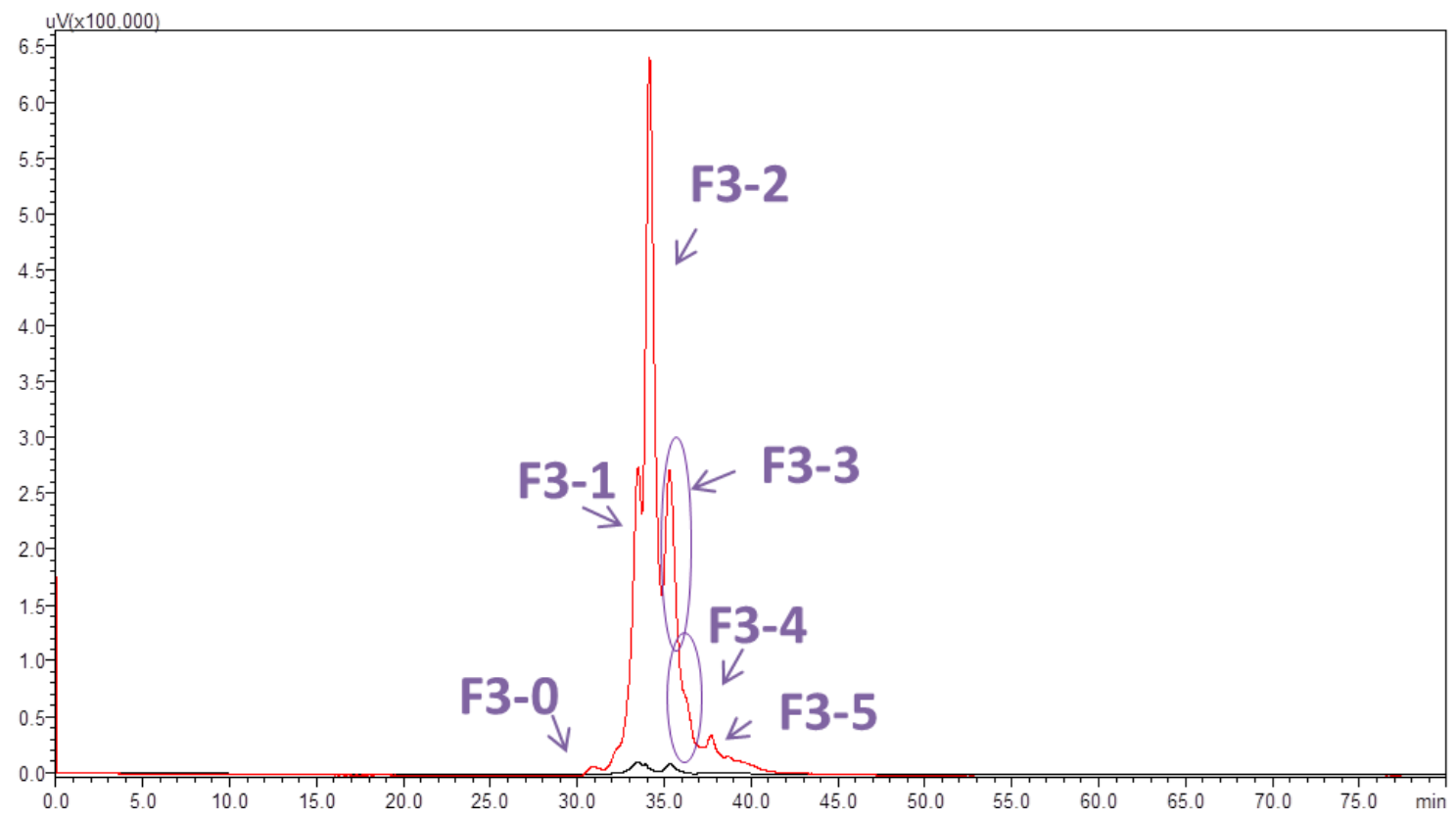

Figura 25 - Perfil cromatográfico da fração F3 em gel-filtração utilizando a coluna Diol-300 em sistema HPLC (Shimadzu), $214 \mathrm{~nm}$ (vermelho) e $280 \mathrm{~nm}$ (preto). A amostra foi eluída sob fluxo de $0,5 \mathrm{~mL} / \mathrm{min}$ utilizando tampão sulfato de sódio $200 \mathrm{mM}$, fosfato de sódio $10 \mathrm{mM} \mathrm{pH} \mathrm{7,0,} \mathrm{durante} 80$ minutos.

No caso de F3, foram obtidas seis subfrações após a aplicação da amostra na coluna Diol-300. As frações foram coletadas, concentradas com membrana de corte molecular de $3 \mathrm{kDa}$, dosadas por método de Bradford e testadas com substrato fluorescente e natural, além de serem analisadas em gel de SDS-PAGE de 13\% (Figura 26). 


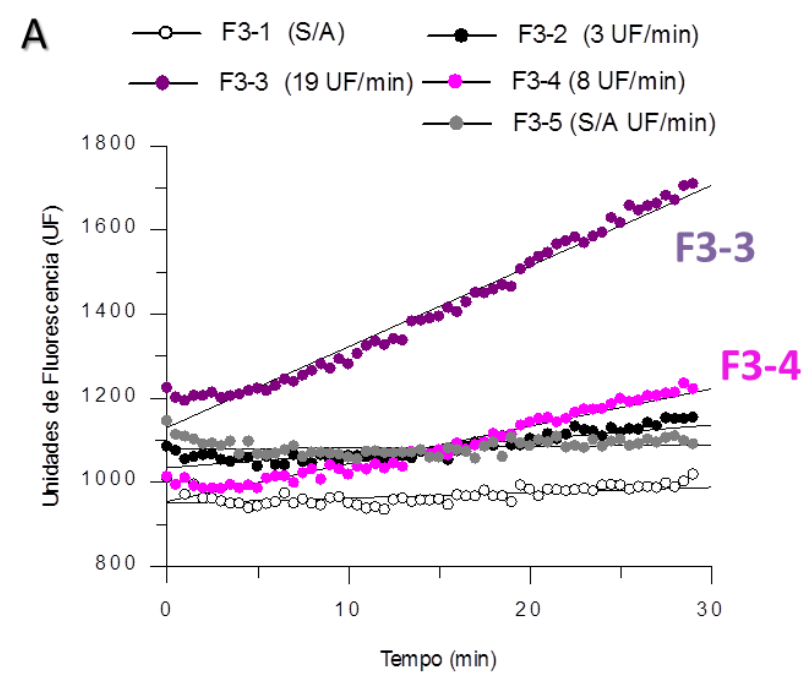

\section{B}

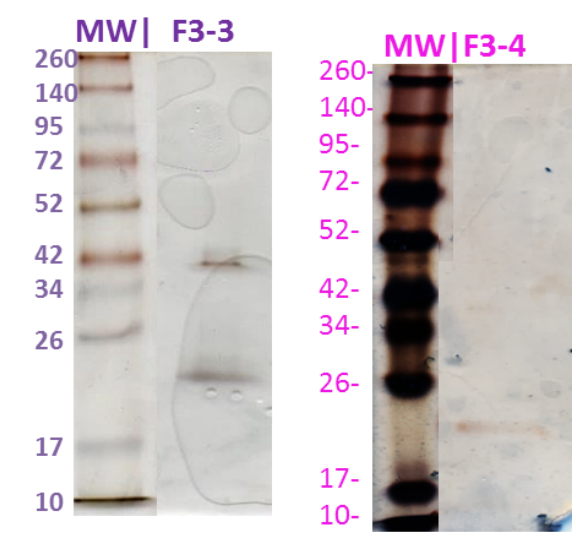

C

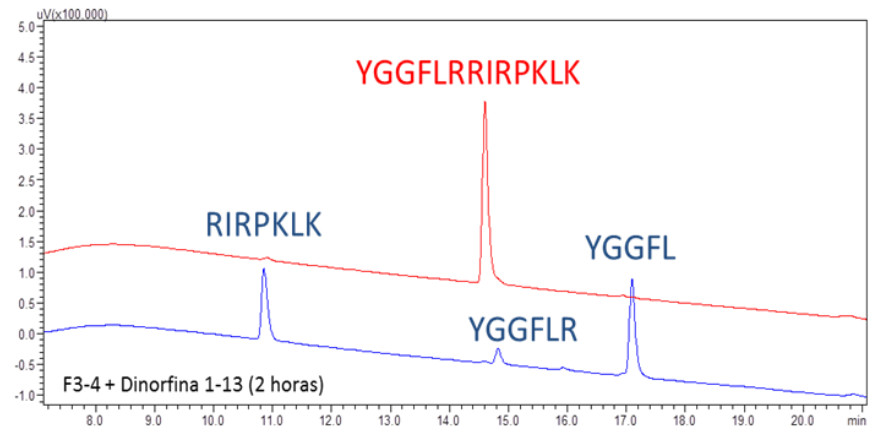

Figura 26 - Resultados das subsfrações de F3 obtidas em gel-filtração: (A) Screening de atividade das subfrações de F3 pós gel-filtração utilizando o substrato Abz-

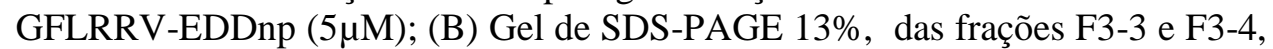
evidenciando a presença de uma banda mais aparente de $24 \mathrm{kDa}$ para F3-4; (C) Ação da fração F3-4 (88 ng) sobre dinorfina 1-13 (2 horas de incubação à $37{ }^{\circ} \mathrm{C}$ ) em fase reversa C-18.

Para a fração F3, as subfrações que demonstraram maior atividade peptidásica foram F3-3, seguida das F3-4 e F3-2. O perfil eletroforético demonstrou a presença de duas bandas bem evidentes em F3-3 (aproximadamente 24 kDa e 42 kDa), e uma banda de aproximadamente $24 \mathrm{kDa}$ em F3-4. Na análise com o substrato biologicamente ativo, foi demonstrado que F3-4 (88 ng) também foi capaz de clivar a dinorfina 1-13, mimetizando a ação do veneno total (Figura 23), sendo observado consumo total do substrato em 2 horas e formação de Leu-encefalina (YGGFL).

A fração F5, a qual apresentava apenas um ponto de clivagem para a dinorfina 1-13 e ausência de liberação de Leu-encefalina, foi também fracionada em coluna de gel-filtração. O perfil cromatográfico desta amostra está demonstrado na Figura 27. 


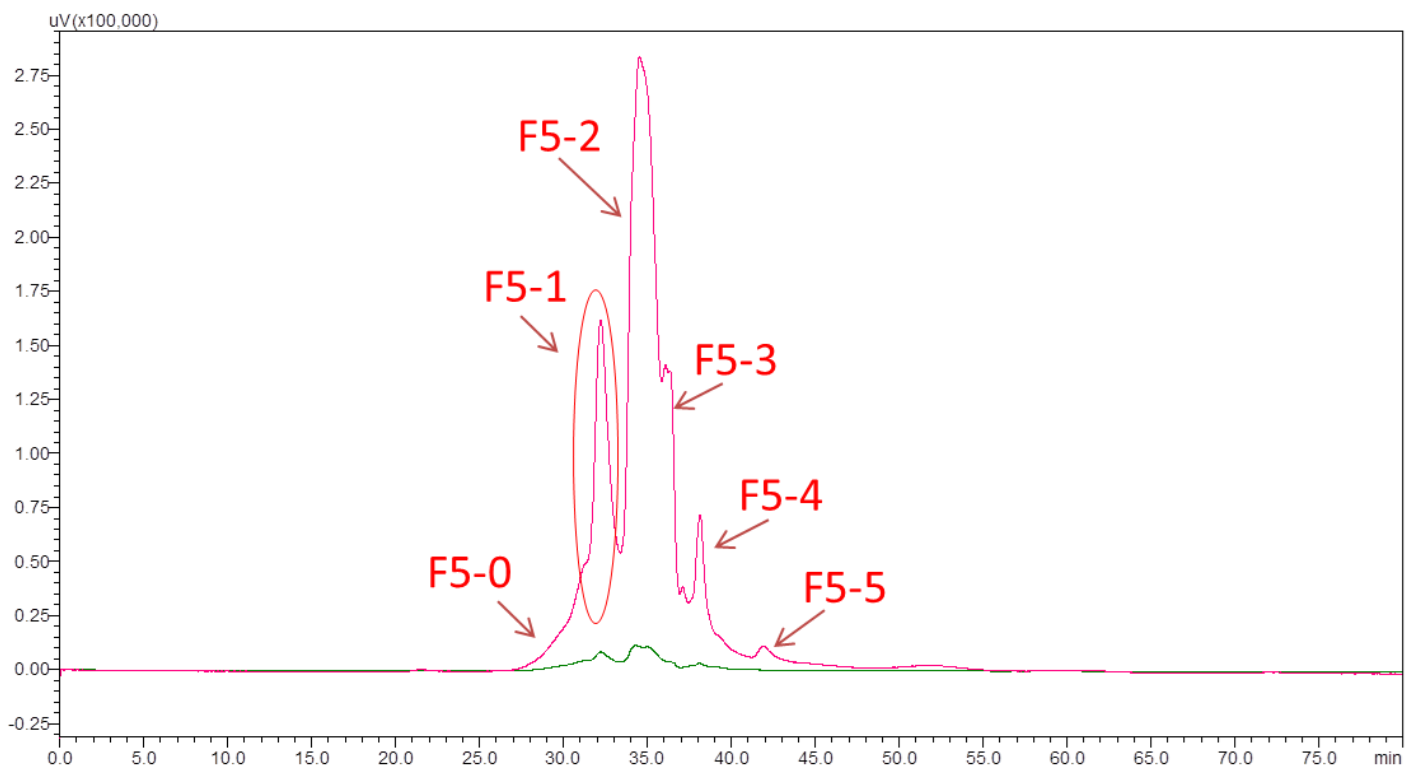

Figura 27 - Perfil cromatográfico da fração F5 em gel-filtração utilizando a coluna Diol-300 em sistema HPLC (Shimadzu), $214 \mathrm{~nm}$ (rosa) e 280 (verde). A amostra foi eluída sob fluxo de $0,5 \mathrm{~mL} / \mathrm{min}$ utilizando tampão sulfato de sódio $200 \mathrm{mM}$, fosfato $10 \mathrm{mM}$, pH 7,0, durante 80 minutos.

Após o fracionamento em coluna de gel-filtração, seis subfrações de F5 (F5-0 a F5-5) foram obtidas. As amostras foram concentradas em membrana de corte molecular de $3 \mathrm{kDa}$, quantificadas por método Bradford e testadas com os substratos natural e fluorescente específicos. A subfração com maior atividade proteolítica também foi analisada em gel de SDS-PAGE 13\% (Figura 28). 

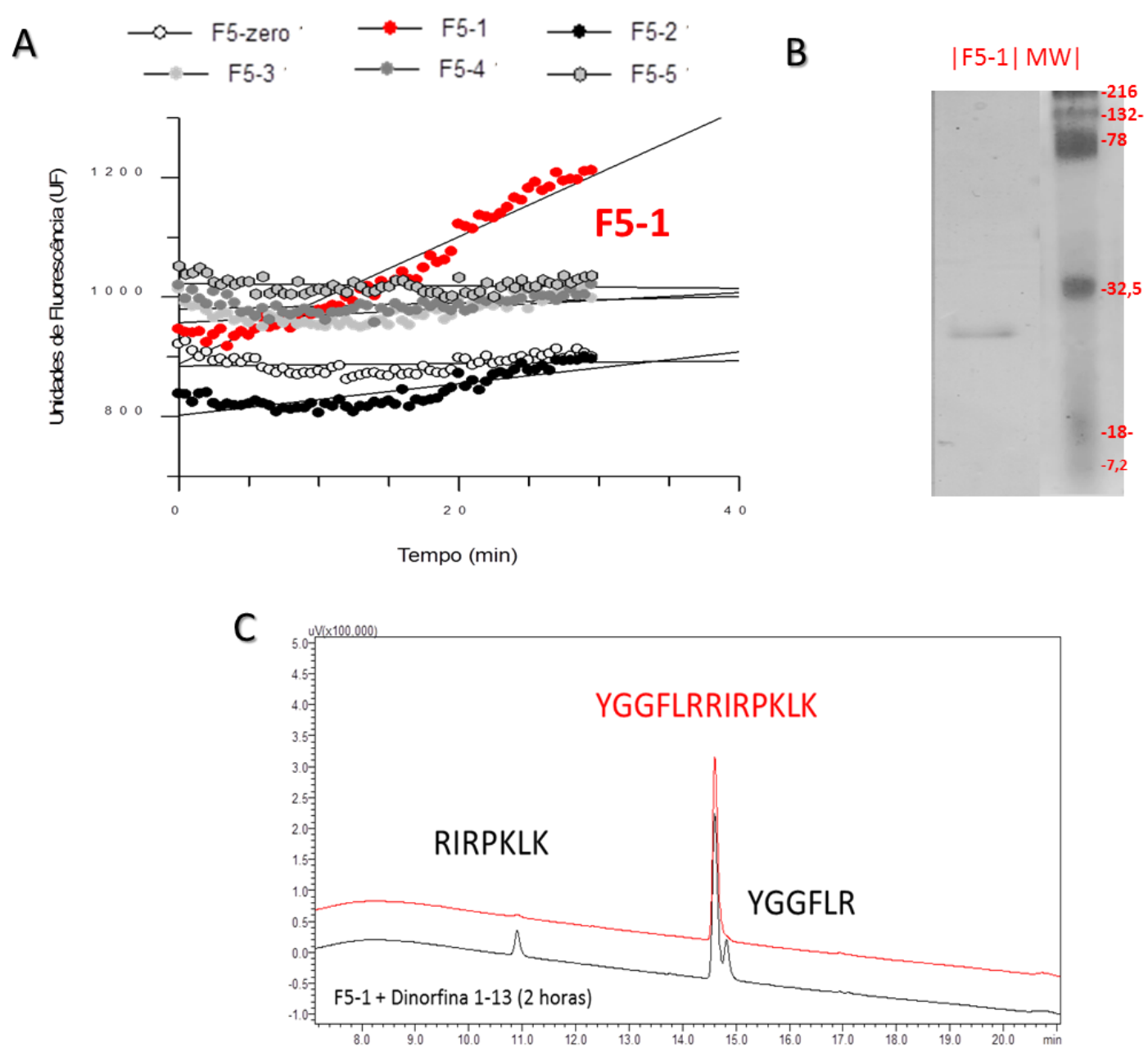

Figura 28 - Resultados das subsfrações de F5 obtidas em gel-filtração: (A) Screening de atividade das subfrações de F5 após a gel-filtração utilizado o substrato AbzFLRRV-EDDnp $(5 \mu \mathrm{M})$; (B) Análise em gel de poliacrilamida 13\% demonstrando banda única com massa molecular de aproximadamente $25 \mathrm{kDa}$; (C) A fração F5-1 mostrou-se capaz de clivar a dinorfina 1-13, porém sem liberação de Leu-encefalina.

No caso das subfrações de F5, apenas as subfrações F5-1 e F5-2 foram capazes de clivar o substrato Abz-GFLRRV-EDDnp (Figura 28, Painel A), porém a fração F5-1 foi mais ativa. A dinorfina 1-13 foi clivada por F5-1, não sendo formada Leuencefalina, assim como esperado (Figura 28, Painel C). Por fim, o gel de poliacrilamida $13 \%$ corado por prata demonstrou banda única e intensa, revelando a homogeneidade da amostra (Figura 28, Painel B). 
4.6.2.3 Análise de massas e bioinformática

Considerando o exposto acima, as frações F3-4 e F5-1 foram selecionadas para a análise por espectrometria de massas. Para tal, as bandas dos géis de SDS-PAGE foram recortadas e os peptídeos resultantes da digestão tríptica foram analisados em espectrômetro de massas Orbitrap do Laboratório Especial de Toxinologia Aplicada (LETA) do Instituto Butantan. Os resultados foram analisados utilizando o software PEAKS, sendo selecionadas como modificações pós traducionais (PTM) a carbaminometilação de cisteínas (como modificação fixa) e, como variável, a oxidação dos resíduos de metionina e a deamidação de asparagina e glutamina, por conta do tratamento utilizado na extração da banda do gel. O índice de falsas descobertas (False Discovery Rate, FDR) foi ajustado para $<0,01 \%$.

A Figura 29 representa o resultado obtido do Peaks DB para a fração F3-4.

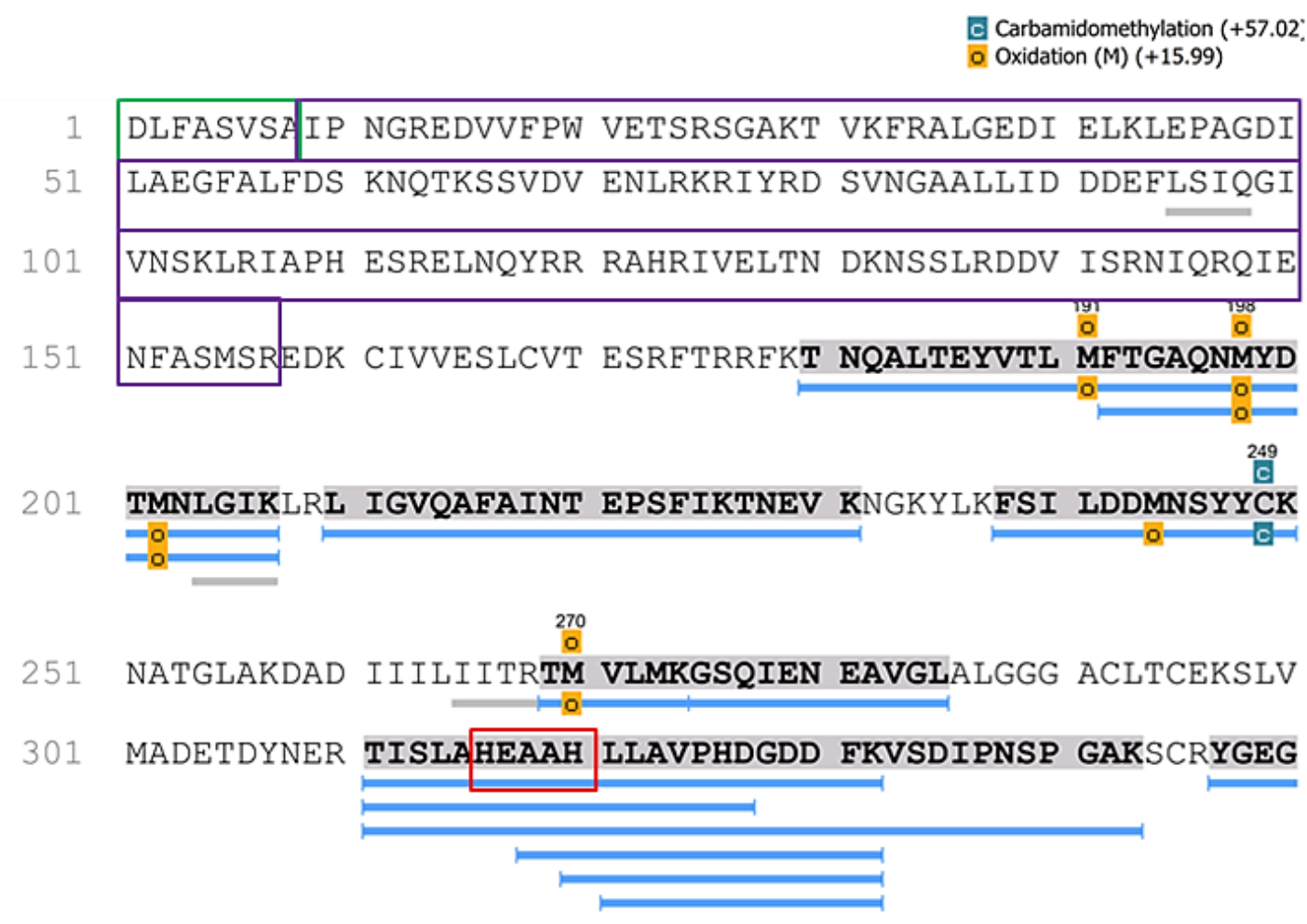

351 YIMGTSIGPN MLKFSKCSIA CAKYFLSLPQ ASCLYEDCPS SAY

Figura 29 - Resultado da banda de F3-4 - Identificação da metalloserrulase 3 de Tityus serrulatus por espectrometria de massas e análise em software Peaks DB, com cobertura de $57 \%$ da molécula madura. Os peptídeos resultantes da digestão in gel da banda de $24 \mathrm{kDa}$ estão marcados em azul e a sequência consenso de metalopeptidases está destacada em vermelho. Em verde, o peptídeo sinal e em roxo a porção do própeptídeo. $\mathrm{O}$ banco de dados utilizado foi UNIPROT/SwissProt (554.567 sequencias), com restrição taxonômica para Metazoa (animals). 
Como resultado do sequenciamento por espectrometria de massas da banda de F3-4, o programa PEAKS foi capaz de identificar a proteína como metalloserrulase 3, (CARMO et al., 2014), com cerca de 57\% de cobertura da molécula madura e $33 \%$ da sequência total, a partir do banco de dados do Uniprot/SwissProt. Foram identificados 14 peptídeos únicos. É importante mencionar que as duas bandas de F3-3 (Figura 26, painel B) também foram submetidas à análise por espectrometria de massas, e resultados similares foram obtidos, ou seja, ambas foram identificadas como metalloserrulase 3 (ms3).

O resultado obtido do PEAKS DB para a fração F5-1 encontra-se expresso na Figura 30.

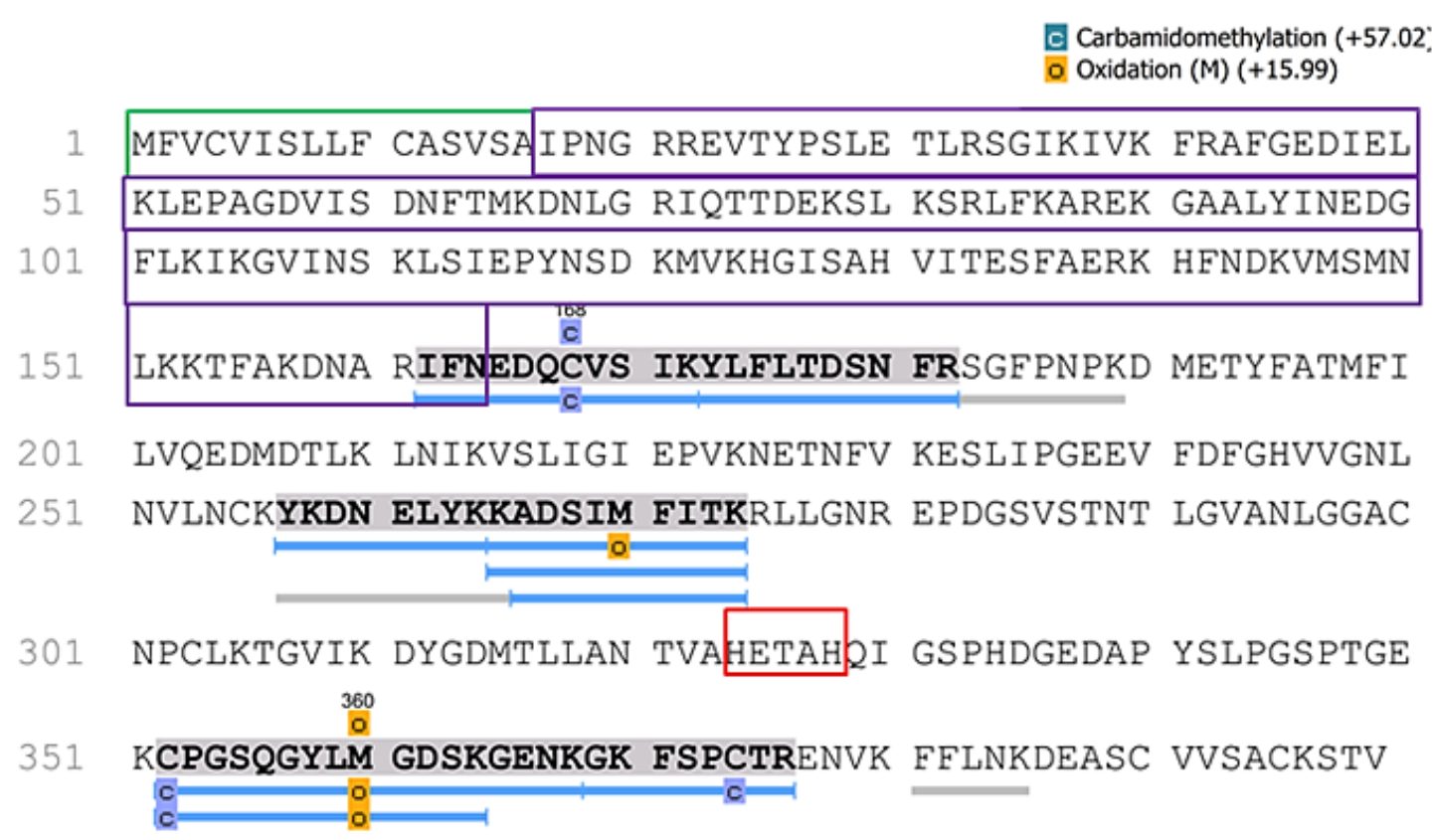

Figura 30 - Resultado da banda de F5-1 - Identificação da metalloserrulase 4 de Tityus serrulatus por espectrometria de massas e análise em software Peaks DB, com cobertura de $31 \%$ da molécula madura. Os peptídeos resultantes da digestão in gel da banda de $25 \mathrm{kDa}$ estão marcados em azul e a sequência consenso de metalopeptidases está destacada em vermelho. Em verde, o peptídeo sinal e em roxo a porção do própeptídeo. $\mathrm{O}$ banco de dados utilizado foi UNIPROT/SwissProt (554.567 sequencias), com restrição taxonômica para Metazoa (animals).

A banda correspondente a amostra F5-1 foi identificada como metalloserrulase 4 (ms4) de Tityus serrulatus (CARMO et al., 2014), a partir do banco de dados do Uniprot/SwissProt. Os peptídeos sequenciados cobriram cerca de $31 \%$ da molécula madura e $16 \%$ do zimógeno total. 
Por conta de possuírem atividades diferentes, principalmente com relação à liberação de Leu-encefalina a partir da dinorfina 1-13, as sequências da metalloserrulase 3 e metalloserrulase 4 maduras foram comparadas por alinhamento de sequências primárias utilizando a ferramenta BLAST (Figura 31).

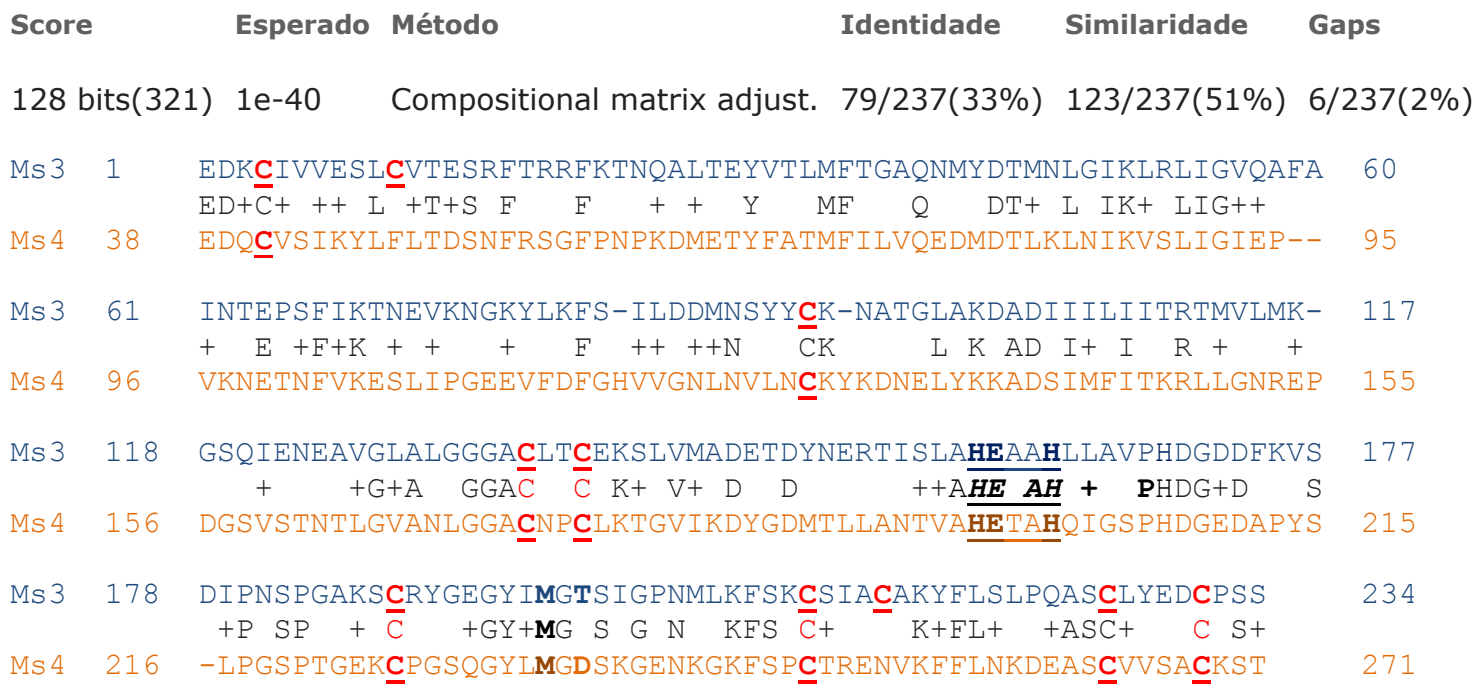

Figura 31 - Alinhamento em BLAST da metalloserrulase 4 e metalloserrulase 3 maduras. Sublinhado, a sequência do sítio ativo de metaloproteases, $\underline{\mathrm{HEXX}} \underline{\mathrm{H}}$. As cisteínas estão marcadas em vermelho.

$\mathrm{O}$ alinhamento entre as metalloserrulases 3 e 4 maduras demonstrou uma identidade de $33 \%$ e $51 \%$ de similaridade. É possível observar também diferença quanto ao número de resíduos de cisteínas nas duas moléculas: enquanto a metalloserrulase 4 tem apenas 8, a metalloserrulase 3 apresenta 10 resíduos (Figura 31), o que pode implicar em diferenças de estrutura tridimensional. Além disso, a metalloserrulase 4 apresenta um motivo metalopeptidase estendido $\underline{\mathrm{HEXX}} \underline{\mathrm{H} X X} \underline{\mathrm{G} X X H}$, característico da família denominada "metzincinas" (que agrupam enzimas como as ADAMs, adamlisina, astacina, entre outras), enquanto a metalloserrulase 3 apresenta uma pequena modificação neste sítio, possuindo alanina ao invés da glicina conservada. A fim de se verificar se tais modificações estariam influenciando a estrutura terciária destas moléculas, foi realizada uma modelagem teórica preliminar de ambas as peptidases usando a ferramenta Phyre $^{2}$. 


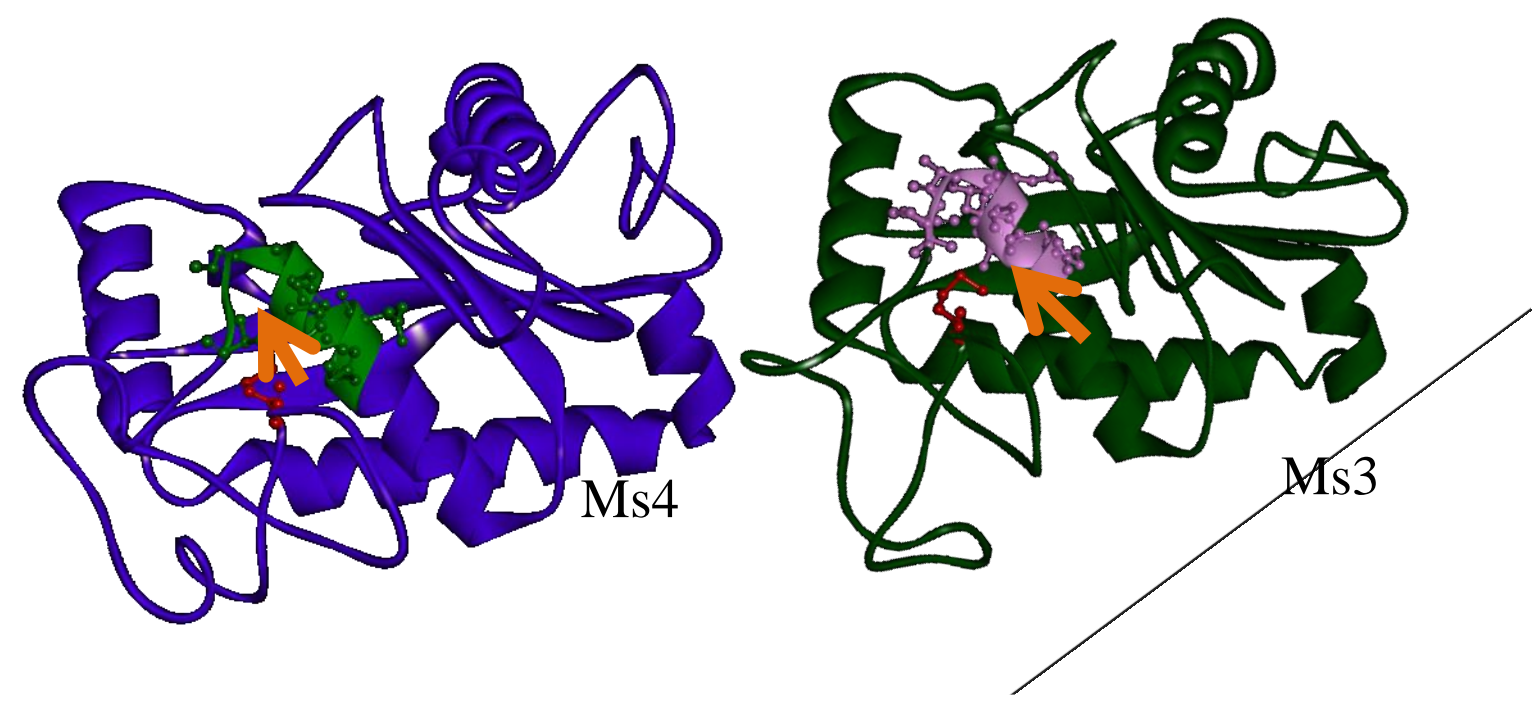

Figura 32 - Modelagem molecular teórica preliminar de metalloserrulase 4 e metalloserrulase 3 usando o software Phyre ${ }^{2}$. Os modelos foram construídos automaticamente pelo software, com confiança de $99 \%$ sobre os resíduos e acurácia de $>90 \%$. O template de maior ranking, baseado na qualidade dos alinhamentos da sequência primária, para ms4 foi ADAM22 (código PDB 3g5c) e para ms3, TNF-alpha converting enzyme (TACE) (código PDB 2i47). Ambos os sítios catalíticos estão marcados em verde (ms4) e rosa (ms3), e a metionina em vermelho. A seta laranja indica a coordenação típica de metzincinas.

Apesar de se tratar de um resultado preliminar, a modelagem molecular teórica demonstra que provavelmente ambas metalloserrulases apresentam conformação típica de "metzincinas", onde a metionina auxilia na coordenação do zinco, embora a ms3 não

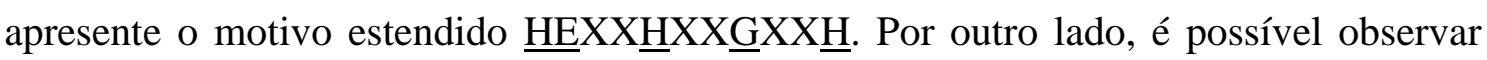
preliminarmente que existem diferenças sutis na estrutura terciária entre estas enzimas. É interessante observar também que a modelagem teórica selecionou por homologia a ADAM22 como template de metalloserrulase 4, e TACE (enzima conversora de TNFalfa) para metalloserrulase 3, ambas enzimas classificadas como metzincinas. Além disso, essa similaridade com metaloproteases humanas podem indicar um papel biológico destas peptidases de veneno de escorpião durante o envenenamento.

\subsection{Caracterizações bioquímicas das metalloserrulases 3 e 4}

\subsubsection{Influência do pH na atividade proteolítica das metalloserrulases 3 e 4}

Para a determinação dos pHs ótimos para ms4 e para ms3, as atividades das enzimas foram avaliadas na presença de diferentes valores de $\mathrm{pH}$ do tampão de trabalho. A faixa de $\mathrm{pH}$ testada foi de 5,0 a 10,0 e os resultados podem ser observados na Figura 33. 

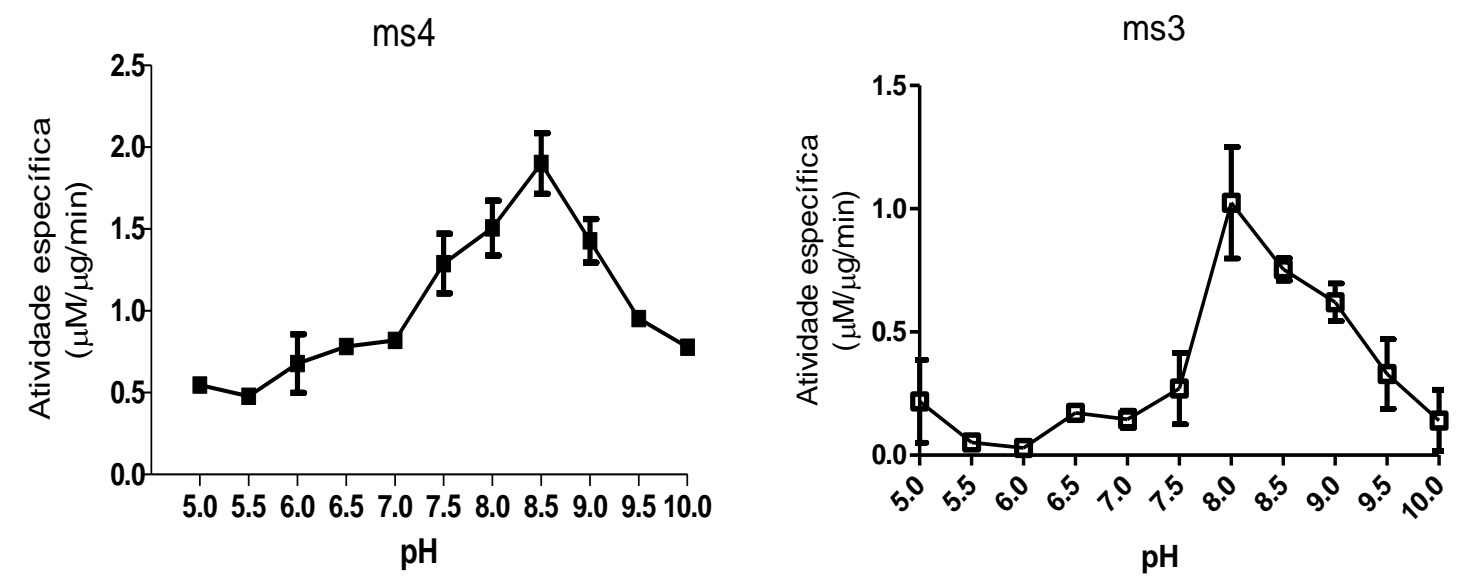

Figura 33 - Influência do pH na atividade específica de metalloserrulase 4 (150 ng) e metalloserrulase 3 (88 ng) utilizando o substrato FRET Abz-GFLRRV-EDDnp.

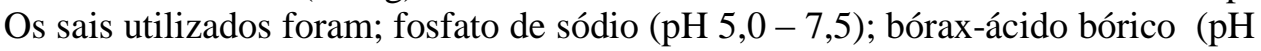
$8,0-9,0)$ e bórax- $\mathrm{NaOH}$ ( $\mathrm{pH} 9,5-10)$. A atividade peptidásica foi monitorada durante 15 minutos. Experimento realizado em triplicata, e velocidades calculadas no software Grafit 5.0. Os gráficos foram construídos no software GraphPad Prism 5.0.

Como é possível observar, a metalloserrulase 4 é ativa entre $\mathrm{pH}$ 5,0 e pH 10,0, contudo, a velocidade de hidrólise em meio ácido é inferior, indicando uma preferência de meio alcalino para o melhor funcionamento desta enzima. O pico de maior atividade detectado foi em $\mathrm{pH} 8,5$.

No caso da metalloserrulase 3 , a sensibilidade a meios ácidos foi mais expressiva, pois a atividade é próxima ou igual a zero abaixo de $\mathrm{pH}$ 6,5. No entanto, em tampões alcalinos ( $\mathrm{pH} 8,0$ e $\mathrm{pH}$ 8,5) tem-se o pico de maior atividade desta peptidase. Por fim, a atividade proteolítica torna a ser drasticamente reduzida em meios muito alcalinos (pH 10,0).

Comparativamente, pode-se observar que a atividade específica de ms4, sobre o substrato FRET Abz-GFLRRV-EDDnp, é o dobro da atividade de ms3, e que valores mais extremos de $\mathrm{pH}$ (mais ácido ou mais alcalino) têm maior influência sobre a atividade de ms3, do que em relação a ms4.

\subsubsection{Influência dos sais mono e bivalentes na atividade das metalloserrulases 3 e 4}

A avaliação da influência de cátions monovalentes $\left(\mathrm{Li}^{+} \mathrm{Na}^{+}, \mathrm{K}^{+}\right)$e bivalentes $\left(\mathrm{Mg}^{2+}, \mathrm{Ca}^{2+}\right)$ na atividade enzimática das metalloserrulases purificadas foi determinada em fluorímetro com a adição de cátions na forma de cloreto $(50 \mathrm{mM})$. O tampão bórax 
$50 \mathrm{mM}, \mathrm{pH} 8,5$ à $37^{\circ} \mathrm{C}$ foi utilizado como controle. O monitoramento da atividade foi realizado durante 15 minutos e os resultados estão expressos na Figura 34.


Figura 34 - Estudo da influência de cátions mono e bivalentes na atividade de metalloserrulase 4 e metalloserrulase 3. Os cátions na forma de cloreto foram adicionados na concentração de $50 \mathrm{mM}$ em tampão bórax $50 \mathrm{mM}$ pH 8,5 para metalloserrulase $4 \mathrm{e}$ bórax $50 \mathrm{mM} \mathrm{pH} \mathrm{8,0} \mathrm{para} \mathrm{metalloserrulase} \mathrm{3.} \mathrm{As} \mathrm{atividades} \mathrm{proteolíticas} \mathrm{sobre} \mathrm{o}$ substrato FRET Abz-GFLRRV-EDDnp de metalloserrulase 4 (150 ng) e metalloserrulase $3\left(88 \mathrm{ng}\right.$ ) foram monitoradas durante 15 minutos a $37{ }^{\circ} \mathrm{C}$. As atividades específicas $(\mu \mathrm{M} / \mu \mathrm{g} / \mathrm{min})$ foram calculadas no software Grafit 5.0 e os gráficos construídos no software GraphPad Prism 5.

De maneira geral, as metalloserrulases são afetadas positivamente por $\mathrm{Na}^{+} \mathrm{e} \mathrm{K}^{+} \mathrm{e}$ negativamente por cátions bivalentes. Contudo, o aumento de atividade na presença de sódio e potássio é menos expressiva na atividade da metalloserrulase 3 do que em comparação com a ms4. A influência do lítio foi mais drástica na redução de atividade de ms3 do que para ms4, ao contrário do cálcio, o qual teve um efeito mais expressivo na diminuição da atividade da metalloserrulase 4 do que da metalloserulase 3 . $O$ magnésio, na concentração utilizada $(50 \mathrm{mM})$ foi capaz de inibir completamente a atividade de ambas as peptidases.

\subsubsection{Determinação da temperatura ideal para melhor atividade catalítica das metalloserrulases 3 e 4 \\ O resultado da influência da temperatura sobre a atividade das metalloserrulases} está demonstrado na Figura 35. 
ms4

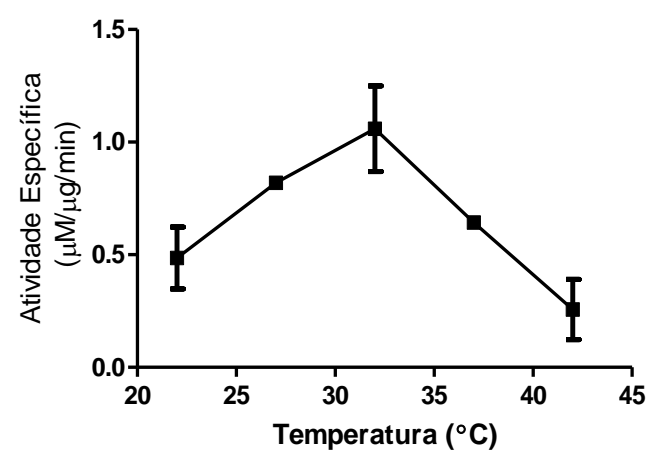

ms3

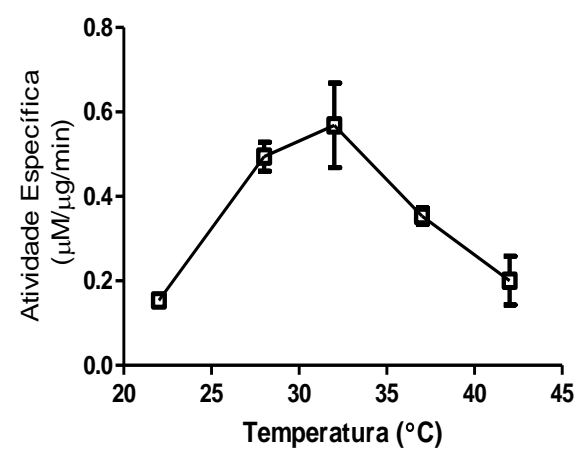

Figura 35 - Influência da temperatura na atividade de metalloserrulase 4 e metalloserrulase 3. Os testes foram realizados em temperaturas entre $22{ }^{\circ} \mathrm{Ce} 42{ }^{\circ} \mathrm{C}$, em intervalos de 5 ${ }^{\circ} \mathrm{C}$. As peptidases foram pré-incubadas durante 15 minutos na temperatura desejada antes da adição do substrato FRET Abz-GFLRRV-EDDnp. A atividade proteolítica foi monitorada durante 15 minutos. Experimento realizado em triplicatas, e velocidades calculadas no software Grafit 5.0.

No geral, as metalloserrulases se comportaram da mesma forma diante variações de temperaturas. Ambas possuem pico ótimo de atividade a $32{ }^{\circ} \mathrm{C}$, e foram ativas e estáveis em todas as temperaturas na faixa testada. Em temperatura de $42{ }^{\circ} \mathrm{C}$, contudo, a atividade proteolítica diminuiu cerca de $50 \%$, indicando uma possível desnaturação de ambas as peptidases.

\subsubsection{Determinação dos pontos de hidrólise preferenciais nos substrato fluorescentes $e$ nos peptídeos bioativos}

O ponto de clivagem do substrato Abz-GFLRRV-EDDnp por metalloserrulase 3 e metalloserrulase 4 foi determinado. A análise foi realizada em cromatografia de fase reversa e posteriormente, por espectrometria de massas em MALDI-TOF. O resultado pode ser observado na figura a seguir.

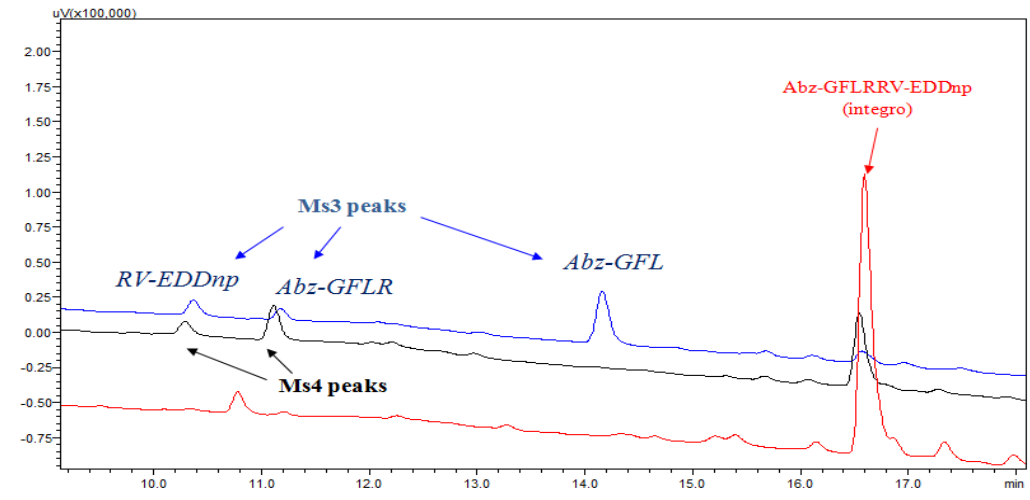

Figura 36 - Perfil cromatográfico da hidrólise de Abz-GFLRRV-EDDnp por metalloserrulase 3 (ms3) e metalloserrulase 4 (ms4). Em vermelho, o perfil do substrato controle; em 
preto, o perfil do incubado do FRET com a enzima ms4; em azul, resultado da clivagem de Abz-GFLRRV-EDDnp por ms3.

Como demonstra a Figura 36, a ms4 hidrolisou o substrato em um único ponto, entre Arg-Arg. Para ms3, dois pontos de clivagem são observados: entre Arg-Arg e entre Leu-Arg. Estes pontos de clivagens correspondem aos obtidos com o substrato natural dinorfina 1-13. É importante destacar que o ponto de clivagem adicional de ms 3 permite a liberação da Leu-encefalina a partir da dinorfina 1-13.

A capacidade das metalloserrulases 3 e 4 de hidrolisarem os substratos membros da família do neuropeptídeo $\mathrm{Y}$ foi verificada, tendo em vista a alta preferência do veneno total por estas moléculas. A Tabela 08 mostra os fragmentos obtidos por análise de espectrometria de massas.

Tabela 08 - Pontos de clivagem dos neuropeptídeo Y (NPY), peptídeo YY (PYY) e polipeptídeo pancreático (PP) pela hidrólise de metalloserrulase $4(\downarrow)$ e metalloserrulase $3(\uparrow)$. Em verde, os pontos de clivagem compartilhados por ambas as peptidases.

\begin{tabular}{|c|c|}
\hline Peptídeo & Fragmento \\
\hline NPY & 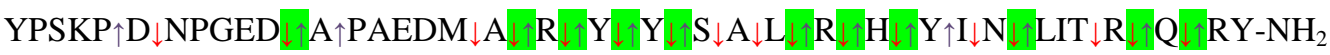 \\
\hline PYY & YPIKPEAPGED $\downarrow$ ASPEEL $\downarrow N \downarrow R \downarrow$ YYASL $\downarrow \uparrow R \downarrow H Y \downarrow L \downarrow N L V T \uparrow R \downarrow Q$ \\
\hline PP & $\mathrm{APLEPMYP} \downarrow \mathrm{G} \uparrow \mathrm{D} \uparrow \mathrm{Y} \uparrow \mathrm{A} \uparrow \mathrm{TH} \uparrow \mathrm{E} \uparrow \mathrm{Q} \uparrow \mathrm{RAQ} \uparrow \mathrm{YETQL} \downarrow \downarrow \mathrm{R} \uparrow \mathrm{R} \downarrow \uparrow \mathrm{Y} \uparrow \mathrm{INTLTR} \downarrow \uparrow \mathrm{PRY}-\mathrm{NH}_{2}$ \\
\hline
\end{tabular}

A Tabela 08 mostra que o neuropeptídeo Y foi o substrato preferencial para as metalloserrulases testadas, apresentando maior quantidade de pontos de clivagem (17 pontos de clivagem para ms4 e 14 para a ms3) do que em relação aos demais substratos que foram atingidos em 10 pontos de clivagem ou menos. É interessante relembrar que o NPY também foi o melhor substrato para o veneno total, onde mais fragmentos foram formados em relação aos demais (Tabela 02), totalizando 40 produtos de hidrólise. Em adendo, alguns pontos de hidrólise são compartilhados por ambas as metalloserrulases (Tabela 08, realce verde), contudo a maioria dos fragmentos formados é exclusiva de cada uma das peptidases. Além disso, o polipeptídeo pancreático é mais hidrolisado por ms3, no passo que o peptídeo YY apresenta mais pontos de hidrólise na presença de 
ms4, indicando certa especificidade destas enzimas. Pode-se dizer também que parte dos fragmentos formados pelo veneno total (Tabela 02) é produto de hidrólise das metalloserrulases 3 e 4, contudo um maior número de pontos de clivagem foram formados pelo VTs. Por fim, o resultado demonstra a ausência do C-terminal amidado nos fragmentos formados por ambas as metalloserrulases, assim como constatado para o veneno total.

A partir da obtenção dos fragmentos, foi possível realizar o estudo dos sítios preferenciais de clivagem das metalloserrulases 3 e 4 (Figura 37).

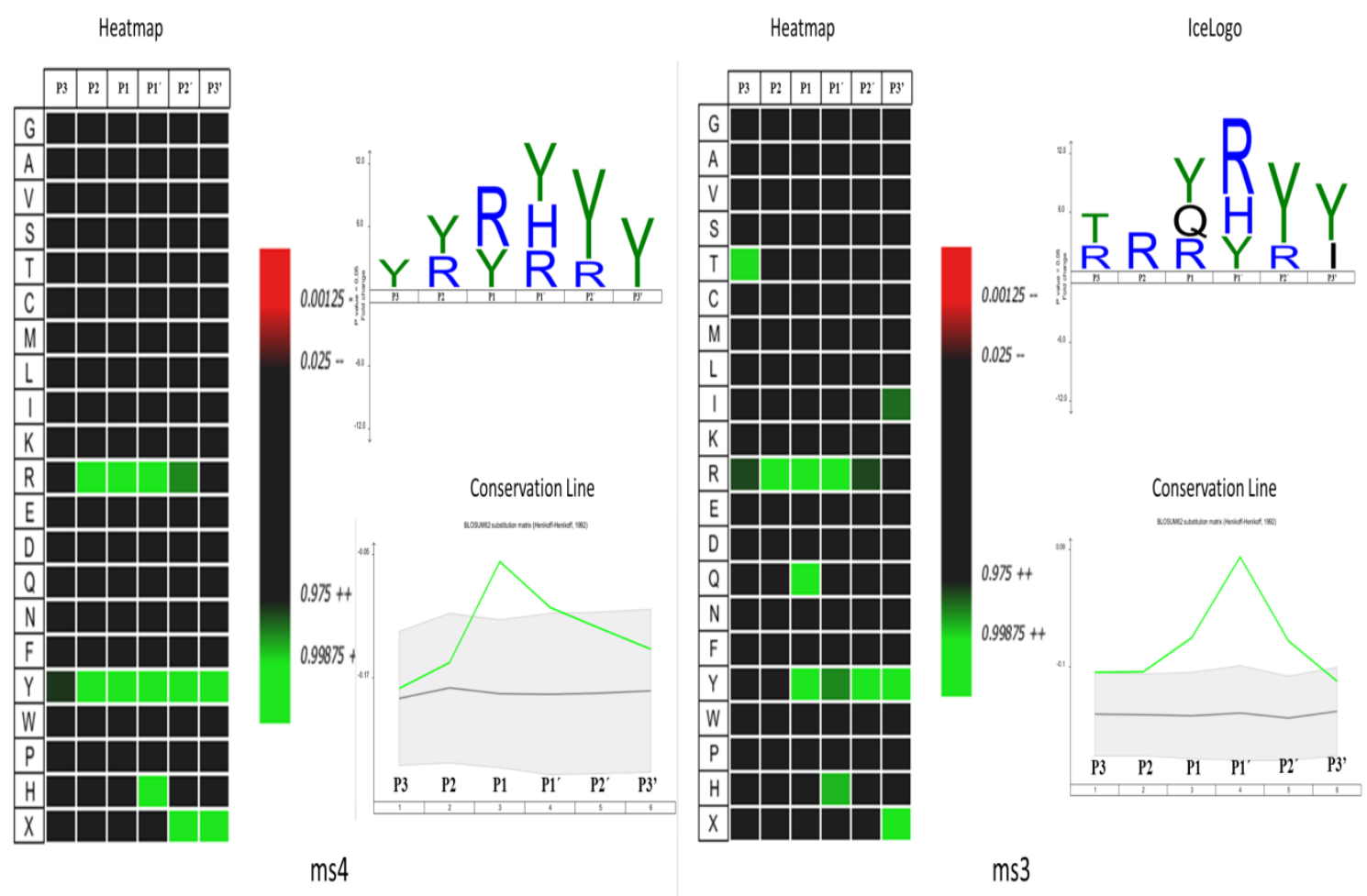

Figura 37 - Estudo dos sítios preferencias dos substratos clivados por metalloserrulase 4 e metalloserrulase 3 com auxílio do software IceLogo (COLAERT et al., 2009).

Como mostrado acima, pode-se dizer que ambas as metalloserrulases apresentam grande preferência para a hidrólise de substratos que possuem resíduos de arginina e tirosina, independente de seu posicionamento na sequência clivada. No entanto, segundo dados obtidos pelo software IceLogo (Figura 37, conservation line), a ms4 mostra preferência para a hidrólise de substratos contendo arginina na posição P1, enquanto a ms3 possui maior especificidade para a hidrólise de substratos que apresentam o resíduo de arginina na posição P1'. Em ambos os casos, o resíduo de arginina é detectados nestas respectivas posições com três vezes mais frequência do que 
em relação aos outros aminoácidos. Adicionalmente, a metalloserrulase 3, além da preferência para a hidrólise de substratos contendo Arg e Tyr, pode apresentar especificidade por glutamina $(\mathrm{Q})$ na posição $\mathrm{P} 1$.

\subsubsection{Determinação dos parâmetros cinéticos da metalloserrulase 4}

A determinação da constante de Michaelis-Menten $\left(\mathrm{K}_{m}\right)$ e catalítica $\left(\mathrm{k}_{\text {cat }}\right)$ para a hidrólise de substratos análogos a dinorfina 1-13 (Abz-GFLRRV-EDDnp, Abz-GFLRREDDnp; e Abz-FLRRV-EDDnp) pela metalloserrulases 4 foi realizada, e estão demonstradas na Tabela 09. Como a metalloserrulase 3 apresentou dois pontos de clivagem no substrato Abz-GFLRRV-EDDnp (Figura 36), não foi possível a determinação de suas constantes catalíticas.

Tabela 09 - Determinação das constantes cinéticas da metalloserrulase 4 purificada em $\mathrm{pH}$ ideal. Os valores de $\mathrm{K}_{m}$ e $\mathrm{k}_{c a t}$ foram obtidos no software Grafit 5.0.

\begin{tabular}{cccc}
\hline Substrato & $\begin{array}{c}\mathbf{K}_{\boldsymbol{m}} \\
(\boldsymbol{\mu M})\end{array}$ & $\begin{array}{c}\mathbf{k}_{\text {cat }} \\
\left(\mathbf{s}^{-1}\right)\end{array}$ & $\begin{array}{c}\mathbf{k}_{\text {cat }} / \mathbf{K}_{\boldsymbol{m}} \\
\left(\mathbf{s}^{-1} / \boldsymbol{\mu M}\right)\end{array}$ \\
\hline Abz-GFLRRV-EDDnp & $16,2 \pm 6,3$ & $491,67 \pm 59,0$ & 29,62 \\
Abz-GFLRR-EDDnp & $36,6 \pm 6,8$ & $170,83 \pm 8,5$ & 4,67 \\
Abz-FLRRV-EDDnp & $28,1 \pm 2,6$ & $1108,33 \pm 33,2$ & 39,44 \\
Abz-FLRRV-EDDnp PBS pH 7,4 & $14,49 \pm 5,9$ & $170,83 \pm 16,6$ & 11,79 \\
\hline
\end{tabular}

Segundo dados obtidos para a metalloserrulase 4, apesar do substrato AbzGFLRRV-EDDnp apresentar o menor $\mathrm{K}_{m}(16,2 \mu \mathrm{M})$, o substrato Abz-FLRRV-EDDnp $\left(\mathrm{K}_{\mathrm{m}}=28,1 \mu \mathrm{M}\right)$, mostrou cerca de 1,5 vezes maior constante de especificidade $\left(\mathrm{k}_{\text {cat }} / \mathrm{K}_{m}\right)$ em $\mathrm{pH} 8,5$, por conta do alto valor de $\mathrm{k}_{\text {cat }}$ apresentado para a hidrólise deste último substrato. Contudo, em meio neutro a constante de especificidade para o substrato AbzFLRRV-EDDnp reduz em três vezes, pois apesar do $\mathrm{K}_{m}$ ter uma grande melhora (redução de 50\%), o valor de $\mathrm{k}_{\text {cat }}$ foi seis vezes inferior ao obtido em $\mathrm{pH}$ ideal. O aminoácido Valina em C-terminal mostrou-se um fator importante na interação com o substrato com esta enzima, pois a constante de especificidade da ms4 sobre o substrato Abz-GFLRR-EDDnp foi reduzida, apresentando o mais alto valor de $\mathrm{K}_{m}$ e mais baixo $\mathrm{k}_{\text {cat }}$ dentre os substratos testados neste $\mathrm{pH}$. 
4.8 Ensaio de inibição da atividade das metalloserrulases pelos antivenenos comerciais

Tendo em vista que o presente trabalho visa avaliar o potencial de soroneutralização das peptidases isoladas de $T$. serrulatus, o ensaio de inibição de atividade de ms4 e ms3 pelos soros comerciais foi realizado. O resultado encontra-se demonstrado na Figura 38.
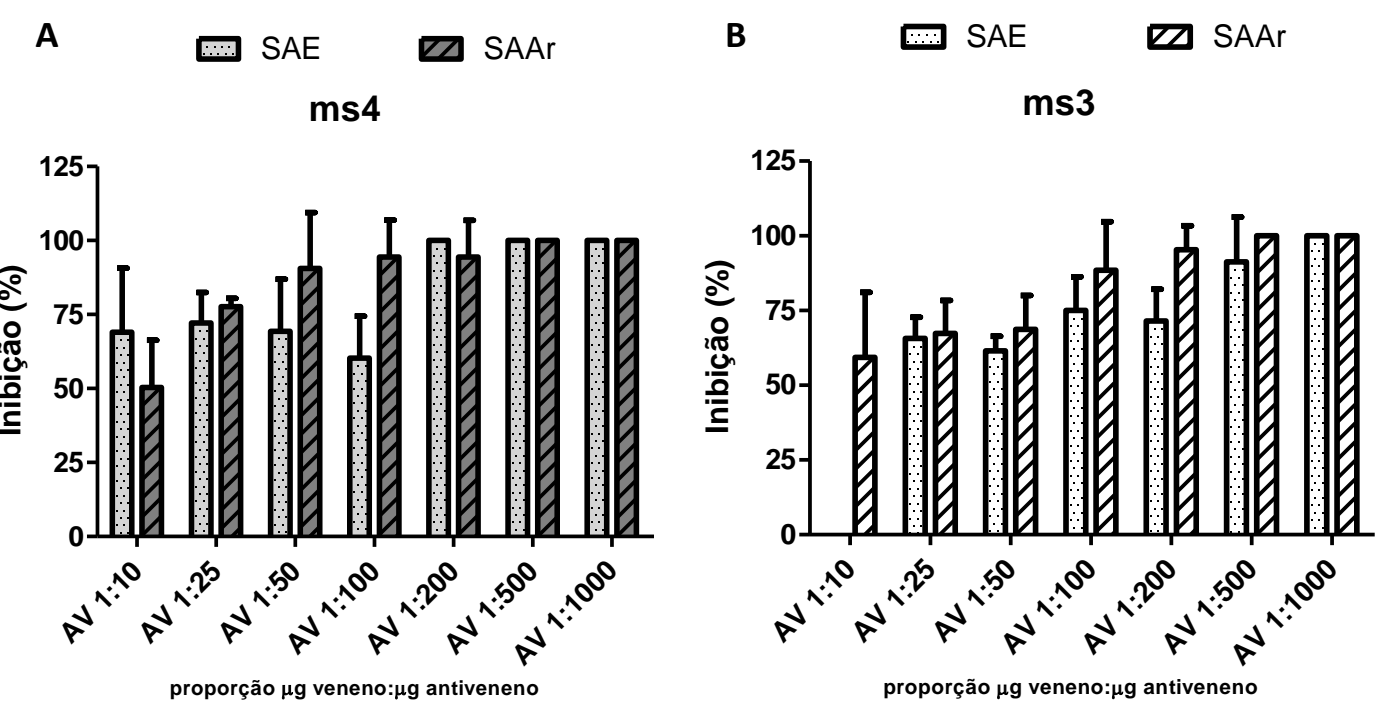

Figura 38 - Ensaio de inibição por soroneutralização utilizando o substrato Abz-FLRRVEDDnp e as peptidases isoladas (A) metalloserrulase 4 (100 ng) e (B) metalloserrulase 3 (88 ng) em tampão PBS pH 7,4. O veneno foi previamente incubado sem substrato durante 30 minutos $37{ }^{\circ} \mathrm{C}$, com sete concentrações (relação massa veneno/massa antiveneno): $1: 10 ; 1: 25 ; 1: 50 ; 1: 100 ; 1: 200 ; 1: 500$ e 1:1000 e as velocidades de hidrólise foram comparadas ao controle (sem antiveneno). O resultado é relativo à média de três experimentos independentes com erro padrão e expressa a porcentagem de inibição da atividade proteolítica (\%). SAE= soro antiescorpiônico e SAAr= soro antiaracnídico.

O ensaio de inibição por soroneutralização demonstrou efetividade em baixas quantidades de antiveneno (1:10). Para ms3, a neutralização por SAAr foi observada em doses menores do que em reação à $\mathrm{SAE}$, assim como observado com o veneno total (Figura 08). Por outro lado, ms4 apresentou, no geral, uma melhor soroneutralização por SAE, mostrando eficiência acima de 50\% quando a dose 10 vezes superior ao veneno foi utilizada (1:10). Para ambas, no geral, foi possível observar aumento da inibição com o incremento da quantidade de antiveneno, e a soroneutralização total foi atingida na dose de 1:500 para ambas as peptidases. 


\section{DISCUSSÃO}

Os venenos animais são formados por uma mistura de toxinas de diversas naturezas, com diferentes ações biológicas, sendo fonte de obtenção de moléculas bioativas. Dentre essas moléculas, as peptidases estão presentes em venenos de diversos organismos, o que indica a importância destas moléculas para sua sobrevivência. Para exemplificar, um estudo comparativo com várias espécies animais, incluindo serpentes, anfíbios, lagartos e artrópodes (aranhas, escorpiões, formigas e abelhas) foi capaz de detectar atividade peptidásica no veneno de todos os seres testados, contudo com diferentes graus de atividade (TAN; PONNUDURAI, 1992). Mesmo assim, é importante lembrar que as peptidases, assim como os hormônios, exercem suas funções em concentrações baixas nos fluidos fisiológicos, não sendo necessárias, portanto, grandes quantidades dessas moléculas para que seus efeitos sejam observados.

Diferentemente das serpentes, os venenos de artrópodes são pouco estudados quanto aos seus componentes proteolíticos, apresentando um maior foco nos componentes ativos em tecidos excitáveis, como as neurotoxinas. Tal fato pode ser explicado pela ausência de efeitos conhecidos de peptidases no envenenamento ou até mesmo pela dificuldade de obtenção de quantidades ideais desses venenos para o isolamento de tais moléculas. Felizmente, as técnicas "ômicas" (proteômicas e transcriptômicas) têm recentemente auxiliado no estudo de peptidases nos venenos desses aracnídeos (ALMEIDA et al., 2012; ALVARENGA et al., 2012; MORGENSTERN et al., 2011). Particularmente, estudos transcriptômicos têm demonstrado que as peptidases são os componentes mais abundantes em alguns venenos de escorpião, como em T. bahiensis, representando 36\% dos transcritos deste veneno (DE OLIVEIRA et al., 2015).

O aumento do interesse pelos acidentes ocasionados por escorpiões no âmbito da saúde pública é reflexo do crescimento da ocorrência destes acidentes. Desta maneira, o conhecimento sobre os componentes do veneno e seus mecanismos de ação torna-se extremamente relevante. Além disso, também é importante o conhecimento do potencial neutralizante dos antivenenos comerciais frente a novas toxinas, uma vez que seu uso é o tratamento utilizado e recomendado pelo Ministério da Saúde (MINISTÉRIO DA SAÚDE, 2009). 


\subsection{Estudos com o veneno total para screening de atividades relevantes}

Neste trabalho, foi possível observar a clivagem de peptídeos que possuem papel importante na fisiologia de mamíferos: família do neuropeptídeo Y, hemopressina, angiotensina I e bradicinina.

Apesar de serem agrupados na mesma família por conta de sequência, estrutura tridimensional e receptores semelhantes, os membros da família do neuropeptídeo $\mathrm{Y}$ apresentam funções diferenciadas. O neuropeptídeo Y é encontrado abundantemente no sistema nervoso e participa de diversos processos, como vasoconstrição (induzido por noradrenalina), ação antiepilética, redução de estresse e ansiedade, redução de percepção da dor. O peptídeo YY é encontrado principalmente no intestino, auxiliando no controle de apetite e aumentando a absorção de água e de eletrólitos no colón, além de suprimir a secreção pancreática. Por sua vez, o polipeptídio pancreático tem papel importante na regulação de secreções pancreáticas (CONLON, 2002; GRUNDEMAR; HÅKANSON, 1990). A hemopressina, substrato para as peptidases do veneno, é uma molécula encontrada no sistema nervoso central, que auxilia na redução da sensibilidade dor e na regulação da pressão arterial (DALE et al., 2005). A angiotensina I e bradicinina são importantes para o controle de pressão arterial, sendo moléculas chave em dois sistemas conhecidos como Renina-Angiotensina-Aldosterona (RAA) e Calicreína-Cinina, respectivamente. Assim, alguns sintomas observados durante o envenenamento podem estar relacionados com a destruição ou a manutenção dessas moléculas pela ação de peptidases e, por este motivo, foram escolhidas para serem estudadas enquanto substratos para o VTs.

A clivagem de dinorfina 1-13 pelo VTs já foi caracterizada por nosso grupo em trabalhos prévios (VENANCIO et al., 2013). Brevemente, a dinorfina 1-13 é um neuropeptídeo opióide endógeno com efeito nociceptivo 100 vezes superior ao da morfina, e a inativação desta molécula pelo VTs pode estar parcialmente relacionada com a intensa dor relatada pelos pacientes. Além disso, a Leu-encefalina, produto da hidrólise de dinorfina 1-13, dentre outras funções, pode causar entrada de correntes de potássio em neurônios da região centro respiratória, ocasionando uma hiperpolarização das membranas e resultando em uma ação inibitória na atividade dos neurônios (INYUSHKIN, 2007). Portanto, uma das possíveis consequências da ação de peptidases do veneno total seria a interação com canais iônicos por ação indireta. Por fim, é importante dizer que a dinorfina 1-13 não é o precursor natural deste pentapeptídeo, que endogenamente é formado a partir da pró-encefalina pela ação de convertases 
(SALZET, 2001). Assim, o veneno do T. serrulatus é capaz de inativar in vitro um neuropeptídeo (dinorfina 1-13), com formação de outro neuropeptídeo (Leu-encefalina), com consequências in vivo ainda desconhecidas.

Nos peptídeos que se comportaram como melhores substratos para o veneno, ou seja, os componentes da família do neuropeptídeo Y (polipeptídeo pancreático e peptídeo YY), verificamos que a remoção da tirosina amidada $\left(\mathrm{Y}_{36}-\mathrm{NH}_{2}\right)$ foi uma modificação constantemente observada nos fragmentos próximos ao C-terminal da molécula. A amidação presente no carboxiterminal é considerada de extrema importância para os peptídeos da família do NPY, sendo responsável pela ligação dessas moléculas em seus receptores. A remoção da tirosina amidada, portanto, causaria perda da atividade in vivo destes peptídeos (GRUNDEMAR et al., 1990).

Em particular, é relevante apontar que a queda de níveis de neuropeptídeo Y e de polipeptídeo pancreático têm consequências fisiológicas já descritas e que podem ter relação com sintomas do envenenamento. Estudos demonstram que a queda de NPY circulante pode estar relacionada com alterações comportamentais, tais como ansiedade e depressão (SERAFINI et al., 2013). Sendo assim, possivelmente algumas das desordens neurológicas observadas nos envenenados por $T$. serrulatus (COLOGNA et al., 2009), tais como agitação e confusão mental, podem estar associadas à degradação ou inativação de NPY, juntamente com a ação das neurotoxinas e/ou outras moléculas.

Por outro lado, alterações de PP geralmente estão relacionadas a desordens patológicas como obesidade e pancreatite (TISCORNIA et al., 2015). Em especial, pacientes com pancreatite crônica associada ao alcoolismo têm concentrações de PP significantemente mais baixas quando comparadas com humanos saudáveis, tanto em níveis basais quanto após a ingestão de alimentos (PIERAMICO et al., 1995). Levando isso em conta, é possível que a inativação deste peptídeo pelo VTs contribua com a disfunção exócrina do pâncreas em pacientes envenenados. Apesar da pancreatite não ser um sintoma comum para o envenenamento por Tityus serrulatus, esta complicação já foi reportada como consequência do envenenamento por vários escorpiões, incluindo do gênero Tityus (Tityus trinitatis) (ORTIZ et al., 2014). Além disso, estudos demonstraram que o VTs é capaz de alterar in vitro a descarga exócrina do pâncreas, podendo tanto estimular quanto inibir dependendo da dose, metodologia ou mecanismo estudado (FLETCHER et al., 1994; FLETCHER et al., 2010). Curiosamente, alguns autores sugerem que esses efeitos do veneno sobre a secreção pancreática não são somente causados por neurotoxinas, mas também por ação sinérgica com outras 
moléculas presentes no veneno (ORTIZ et al., 2014). Em conclusão, pode-se dizer que os efeitos do veneno sobre a secreção pancreática podem ter relação com a inativação do polipeptídeo pancreático.

Apesar de não possuírem atividade similar à molécula original, os fragmentos gerados pela hidrólise dos peptídeos da família do NPY pelo VTs podem ser ativos em outros sistemas ainda não relacionados, como o que provavelmente ocorre durante a clivagem de dinorfina pelo VTs com a liberação de Leu-encefalina, que é um fragmento ativo. Em adendo, a observação dos fragmentos formados permitiu a clara observação de endo e exopeptidases no veneno do escorpião amarelo. É interessante notar que, com o estudo de especificidade das peptidases (ms3 e ms4) purificadas, fica claro que a remoção das tirosinas é devido a grande preferência das metalloserrulases por este aminoácido, independentemente de sua posição na sequência do substrato. Tal fato reforça a importância de estudos bioquímicos de tais moléculas para a compreensão dos mecanismos de ação do veneno.

Os peptídeos angiotensina I e bradicinina também foram clivados pelo VTs,

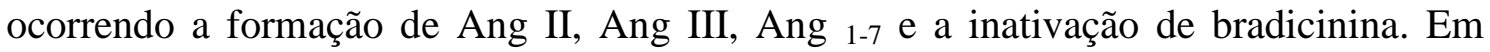
relação aos aspectos fisiológicos, a Ang II e Ang III contribuem para o aumento da pressão sanguínea, pois ambas são capazes de ligar nos receptores de Ang II (MARC; LLORENS-CORTES, 2011; REAUX et al., 2001), estimulando a vasoconstrição. Além disso, observamos a inativação da bradicinina por amino- e carboxipeptidase(s) presentes no VTs, sendo que esta degradação também pode contribuir para efeitos hipertensivos do veneno. Por outro lado, a Ang 1-7 não se liga a receptores de Ang II, mas sim ao receptor denominado "Mas", com isso promovendo vasodilatação e levando a hipotensão arterial (FERRARIO, 2006). Assim, a formação de Ang II/Ang III pelo VTs contrastaria à atividade hipotensiva de Ang 1-7. Contudo, tal paradigma corrobora com os efeitos do envenenamento na vítima, uma vez que a hipertensão é seguida de uma intensa hipotensão (BUCARETCHI et al., 2014) podendo, em partes, ser explicada pela formação destes peptídeos pela ação peptidásica do veneno total. Por fim, apesar de claramente mais de uma enzima atuar na clivagem destes substratos no veneno total, é possível estabelecer uma relação de atividade típica de enzima conversora de angiotensina I (ACE), a qual forma Ang II e inativa BK pela remoção de dois aminoácidos a partir do carboxiterminal dos peptídeos.

Além dos substratos biologicamente ativos, foram utilizados substratos fluorescentes para mensurar a atividade proteolítica do veneno total. Para isso, foram 
selecionados substratos com diferentes propriedades - Abz-GFLRRV-EDDnp para endopeptidases e Abz-FRK(Dnp)P-OH para carboxipeptidases, uma vez que a prolina carboxiterminal encontra-se livre (sem ligação direta do grupo apagador), permitindo a interação com este tipo de exopeptidase. Além disso, este substrato foi construído especificamente para estudos com a enzima conversora de angiotensina I ou ACE (ARAUJO et al., 2000).

Apesar de se tratarem de metalopeptidases, igualmente inibidas pelo EDTA, o uso de inibidores mais seletivos forneceu informações relevantes sobre os tipos de enzimas que agem em cada um dos substratos fluorescentes. O captopril é um inibidor que apresenta seletividade para a ACE, sendo utilizado como fármaco para tratamento da hipertensão humana. O captopril é capaz de inibir outras enzimas relacionadas à ACE como, por exemplo, as ACE-likes presentes na mosca Drosophila, Dcp $\left(\mathrm{K}_{i}=3\right.$ $\mathrm{nM})$ e Ance $\left(\mathrm{K}_{i}=11 \mathrm{nM}\right)$ (RAWLINGS et al., 2014). Além do captopril, o Bj-PRO-10c foi utilizado, sendo este um peptídeo típico inibidor de ACE. De fato, o desenvolvimento do captopril foi baseado na sequência primária dos PROs, Proline

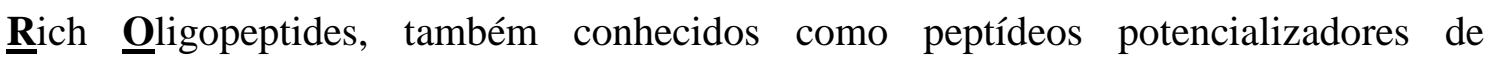
bradicinina (BPPs). Estes peptídeos foram inicialmente purificados de venenos de serpentes, mas já foram descritos em venenos e secreções de diversos animais peçonhentos (VERANO-BRAGA et al., 2009). Com isso, por conta de bons valores de inibição do Bj-PRO-10c e do captopril sobre a hidrólise do substrato Abz-FRK(Dnp)P$\mathrm{OH}$ pelo VTs, foi possível dizer que o veneno apresenta uma atividade ACE-like.

O fosforamidon foi capaz de inibir fracamente a hidrólise de ambos os substratos fluorescentes testados. Apesar de ser capaz de afetar a hidrólise de enzimas das famílias M4 e M3 das metalopeptidases, este inibidor apresenta melhores constantes de inibição para a neprilisina $\left(\mathrm{K}_{i}=43 \mathrm{nM}\right)$ e ECE (Enzima Conversora de Endotelina, $\mathrm{K}_{i}=3,5 \mu \mathrm{M}$ ) do que para a $\operatorname{ACE}\left(\mathrm{K}_{i}=74 \mu \mathrm{M}\right)$. Por outro lado, o tiorfan é descrito como um forte inibidor seletivo para a neprilisina $\left(\mathrm{K}_{i}=4,7 \mathrm{nM}\right)$, apresentando valores menos significativos para ACE $\left(\mathrm{K}_{i}=150 \mathrm{nM}\right)$ (RAWLINGS et al., 2014). O peptídeo [des$\left.\mathrm{Arg}^{1}\right]$-proctolin, por outro lado, é um peptídeo presente no VTs que mostrou seletividade para a inibição da neprilisina $(0,94 \mu \mathrm{M})$, e não é capaz de inibir a ACE (DUZZI et al., 2016). Assim, as baixas porcentagens de inibição por fosforamidon, tiorfan e [des-Arg $\left.{ }^{1}\right]$-proctolin (todas inferiores a 15\%) provavelmente estão atribuídas à fraca seletividade destes inibidores sobre enzimas tipo conversoras de angiotensina I, e à pequena concentração utilizada $(10 \mu \mathrm{M})$ que se distancia das constantes de inibição 
descritas para ACE (RAWLINGS et al., 2014). Por fim, esses resultados indicam que o veneno do T. serrulatus não apresenta enzimas do tipo NEP e ECE-I agindo nesse substrato.

Além de inibir a hidrólise do Abz-FRK(Dnp)P-OH, o captopril também mostrou ser capaz de modular seletivamente a clivagem pelo VTs de peptídeos biologicamente ativo relacionados à $\mathrm{ACE}$ - angiotensina $\mathrm{I}$, bradicinina e hemopressina. A dinorfina 113, utilizada como controle negativo, não teve sua clivagem afetada nas duas concentrações de captopril utilizadas, demonstrando a ação de diferentes enzimas nesses substratos, assim como o observado com os substratos fluorescentes. Apesar de terem sido testadas duas concentrações de captopril, $100 \mathrm{nM}$ e $1 \mu \mathrm{M}$, não foi possível obter inibição total da atividade do veneno sobre esses substratos, pois outras peptidases que atuam nesses substratos não são afetadas por esse inibidor. No caso da hemopressina, foi observado que o fragmento com sequência PVNFKFL, correspondente à ação da ACE humana sobre a hemopressina (BLAIS et al., 2005), não é formado na presença do captopril, o que mais uma vez indica a presença de uma ACE-like no VTs. Em adição, os demais fragmentos PVNFK e FLSH são formados por outra(s) peptidase(s) que não é (são) inibida(s) pelo captopril, mas ao mesmo tempo apresenta(m) ausência de atividade na presença de EDTA.

No caso da bradicinina, aparentemente menos enzimas atuam sobre este substrato, uma vez que somente são formados fragmentos relacionados à atividade ACE humana - $\mathrm{BK}_{1-5}$ e $\mathrm{BK}_{1-7}$ (CAMARGO et al., 2012), além do fragmento $\mathrm{BK}_{3-9}$ provavelmente gerado pela ação de uma aminopeptidase que não é afetada pela presença de captopril, o que pode explicar não ter sido atingido $100 \%$ de inibição na concentração de $1 \mu \mathrm{M}$ de captopril.

A ativação por íons de cloreto sobre a atividade da enzima conversora de angiotensina é bem conhecida (YATES et al., 2014). Em ensaio comparativo, foi demonstrado que a hidrólise de Abz-FRK(Dnp)P-OH pelo veneno total também é aumentada com o incremento de $\mathrm{NaCl}$, sendo esta outra evidência da presença de uma enzima conversora de angiotesina I-like neste veneno.

Neste trabalho também avaliamos a capacidade neutralizante dos antivenenos comerciais do Instituto Butantan - antiaracnídio (SAAr) e antiescorpiônico (SAE) sobre a atividade peptidásica do VTs. Em ambos os casos, foi observada uma inibição parcial da atividade peptidásica do VTs tanto nas hidrólises dos substratos fluorescentes 
quanto nas hidrólises de peptídeos biologicamente ativos quando analisadas nas mesmas concentrações de antiveneno (1:50 e 1:100). Além disso, foram observadas diferenças na curva de inibição por soroneutralização entre endopeptidases (Abz-GFLRRVEDDnp) e exopeptidases (Abz-FRK(Dnp)P-OH). Para o substrato FRET das endopeptidases, a inibição pelo SAAr foi superior a de SAE, sendo necessário uma maior dose de SAE para iniciar a soroneutralização de $1 \mu \mathrm{g}$ de veneno, tendo-se obtido a inibição total na maior dose (1:1000). No caso da atividade de serACE-like, o bloqueio iniciou-se logo na primeira dose de SAE, provavelmente por conta da maior porcentagem de veneno de $T$. serrulatus utilizado na imunização de cavalos (pool de imunização composto por $100 \%$ de veneno de T. serrulatus) em relação ao SAAr (cujo o pool de imunização é composto por $57 \%$ de veneno de T. serrulatus). Apesar disso, na maior dose a inibição da atividade carboxipeptidásica foi próxima a $100 \%$ para ambos os antivenenos.

Para a hidrólise dos substratos biologicamente ativos, na maioria dos peptídeos foi observada uma inibição dose-resposta pelo uso dos antivenenos, com exceção da hemopressina. Novamente, as diferenças de inibição por soroneutralização, principalmente no caso da hemopressina, são explicadas pela presença de diferentes enzimas aminopeptidases, carboxipeptidases e endopeptidases no veneno total, as quais devem possuir diferentes afinidades pelos anticorpos presentes nos antídotos comerciais. Neste caso, o SAAr apresenta melhor poder de inibição do que o SAE também para a hidrólise de substratos biologicamente ativos.

Por fim, a diferença de efeito bloqueador dos dois antivenenos sobre as peptidases provavelmente é devido à concentração de veneno do escorpião amarelo utilizado na imunização dos cavalos para a preparação dos soros: SAE é composto pelos venenos de $T$. serrulatus (100\%) e SAAr por T. serrulatus (57\%), Phoneutria nigriventer (21,5\%) e Loxosceles gaucho (21,5\%). Por outro lado, em termos de reconhecimento antígeno-anticorpo, nosso grupo demonstrou em trabalho anterior que o soro antiescorpiônico apresenta melhor título e melhor reconhecimento em análises de western blot em relação ao soro antiaracnídico para veneno total de Tityus serrulatus (VENANCIO et al., 2013).

A Organização Mundial de Saúde e o Ministério da Saúde preconizam que o uso de antivenenos é, indiscutivelmente, o tratamento mais apropriado para acidentes com animais peçonhentos. Porém, apesar de trabalhos com antivenenos brasileiros comprovarem a eficácia de soros antiescorpiônicos/aracnídeos (DE REZENDE et al., 
1996), outros países continuam avaliando os benefícios de seu uso para o tratamento de ferroada de escorpião. Em estudos clínicos no Egito e na Tunísia, por exemplo, diferenças significativas não foram observadas no prognóstico de pacientes que receberam antiveneno com aqueles não foram tratados por soroterapia (ABROUG et al., 1999; SOFER et al., 1994). Foi demonstrado também que a dose de antiveneno deve ser muito superior as do veneno injetado pelo animal em pacientes envenenados por escorpiões na Arábia Saudita (ISMAIL, 1995). Tal fato pode estar atrelado ao método de produção do antiveneno, o que pode requerer uma maior dose necessária para a inibição da soroneutralização, acarretando em uma maior probabilidade do desenvolvimento de reações adversas aos pacientes, que podem causar urticária, calafrios, tosse, náusea e, nos casos mais severos, reações anafiláticas. Por fim, é interessante pensar que a potência do veneno varia entre as espécies de escorpiões e, como o escorpião brasileiro apresenta alta toxicidade, o uso do antiveneno é indispensável.

\subsection{Purificação da Enzima Conversora de Angiotensina I do veneno de $\underline{\text { Tityus }}$ serrulatus}

A purificação das peptidases iniciou-se pela busca da molécula responsável pela atividade similar a ACE humana. A primeira etapa escolhida foi a troca aniônica e dentre as onze frações obtidas, a fração F1 foi a única capaz de formar o fragmento PVNFKFL e Angiotensina II, os quais são descritos como produtos de hidrólise da ACE humana (BLAIS et al., 2005). Por conta disso, a fração F1 foi selecionada para a etapa seguinte de purificação, a gel-filtração, a qual foi capaz de separar as moléculas de baixa massa do VTs entre outros contaminantes presentes na F1. Na etapa seguinte de purificação, foi levado em conta que a fração F1 era composta por moléculas que não interagiram com a coluna aniônica e, por conta disso, a fração ativa proveniente da gelfiltração foi fracionada em coluna de troca catiônica, obtendo-se uma subfração com atividade sobre Abz-FRK(Dnp)P-OH e novamente capaz formar de angiotensina II a partir de angiotensina I. O perfil eletroforético demonstrou uma banda única próxima a $70 \mathrm{kDa}$, a qual foi analisada em espectrometria de massas, comprovando a purificação da peptidase.

Uma sequência transcrita de ACE foi encontrada na glândula de veneno de $T$. bahiensis (DE OLIVEIRA et al., 2015) e, mais recentemente, nas glândulas de $T$. serrulatus e T. obscurus (de Oliveira, comunicação pessoal), este último com duas sequências. Sendo assim, essas quatro sequências foram adicionadas ao banco de dados 
obtido no UNIPROT/Swissprot para a análise dos resultados obtidos por espectrometria de massas. Os peptídeos provenientes da digestão tríptica da banda de $70 \mathrm{kDa}$ foram identificados como provenientes da enzima conversora de angiotensina I de Tityus serrulatus, sendo detectados dois peptídeos únicos.

Funcionalmente, peptidases com atividade ACE-like foram descritas no veneno de alguns animais como em Conus (SAFAVI-HEMAMI et al., 2013), na vespa endoparasita (DANI et al., 2003) e no peixe brasileiro Niquim (TENÓRIO et al., 2015) sendo demonstrado o processamento de angiotensina I em angiotensina II por essas moléculas e suas inibições pelo captopril. Apesar de até o presente momento estas peptidases não terem sido isoladas, no caso de Conus, a sequência primária foi obtida por análise transcriptômica e indicam similaridade com a ACE humana, com tamanho de aproximadamente 170 kDa (SAFAVI-HEMAMI et al., 2013). Sendo assim, esta é a primeira vez que uma ACE é purificada a partir de um veneno animal e, por conta disso, foi denominada como serACE-like.

A partir do alinhamento das sequências de ACEs preditas do gênero Tityus e a ACE testicular de Homo sapiens, é possível notar a conservação de várias regiões, em especial, cisteínas localizadas na mesma posição e o sítio catalítico com aminoácidos idênticos (HEMGH), o que é um forte indício para uma atividade similar. Além disso, essas proteínas apresentam massas moleculares preditas aproximadas (BLAIS et al., 2005; LEMEIRE et al., 2008) e que corroboram com a banda de aproximadamente 70 $\mathrm{kDa}$ da peptidase purificada obtida no presente trabalho. Curiosamente, é descrito na literatura que todas as enzimas conversoras de angiotensina I em invertebrados são mais aproximadas com a ACE testicular humana por possuírem apenas um sítio de ligação com o zinco, diferentemente do observado na ACE somática, a qual apresenta dois sítios ( $\mathrm{N}$ e $\mathrm{C}$ ) e, consequentemente, maior massa molecular, de 170 kDa (BERNSTEIN et al., 2013).

A função da serACE-like no VTs é incerta. Devido a sua seletividade, a atividade desta peptidase pode estar atrelada ao processamento de peptídeos da peçonha, tendo em vista que já foi demonstrada a importância de enzimas na composição peptídica endógena em venenos animais (TASHIMA et al., 2012; VERANO-BRAGA et al., 2013). A segunda hipótese baseia-se na função do veneno para a captura e paralização da presa, considerando a presença recorrente de ACEs em invertebrados, especialmente em insetos, estando relacionadas com processos fisiológicos como reprodução, função cardíaca e processamento de neuropeptídeos (HARRISON; 
ACHARYA, 2014; ISAAC et al., 1998; LEMEIRE et al., 2008). Apesar do fato destas enzimas serem capazes de clivar angiotensina I e bradicinina, é pertinente lembrar que esses peptídeos não estão presentes em insetos, e provavelmente os alvos moleculares nas presas são diferentes (ISAAC et al., 1998).

Por fim, o envolvimento desta carboxipeptidase durante o envenenamento não pode ser excluído, principalmente pelo fato da hipertensão ser frequentemente observada em envenenados por Tityus spp (BUCARETCHI et al., 2014). A formação de Ang II e Ang III, juntamente com as catecolaminas podem contribuir para esse sintoma. Além disso, trabalhos demonstram que envenenados por escorpiões da família Buthidae apresentam aumento da atividade do sistema renina-angiotensina-aldosterona provavelmente por elevações de Ang II (BAWASKAR; BAWASKAR, 2012; MURTHY; VAKIL, 1988), sendo que esse peptídeo é capaz de estimular a liberação de catecolaminas (DIZ, 2014). Em estudo com crianças envenenadas por escorpiões no Egito, foi mostrada correlação entre a severidade de pacientes com quadro hipertensivo com o aumento dos níveis de angiotensina II, atividade de ACE, catecolaminas e NO (EL-DEEK et al., 2017). Ainda, em ratos envenenados pelo escorpião Androctonus australis hector, também da família Buthidae, foi observada a influência da elevação de níveis de angiotensina II na inflamação cardíaca induzida pelo veneno, sendo que este sintoma é atenuado pelo uso de captopril (SIFI et al., 2017). Por conta do exposto, existem indícios de que provavelmente a serACE-like pode estar contribuindo sinergicamente com outras toxinas na hipertensão desenvolvida durante $o$ envenenamento em humanos. Por último, é interessante pensar que a serACE-like possivelmente tenha ação tanto em insetos quanto em mamíferos. Isso se deve provavelmente por conta de certos alvos moleculares presentes em ambos os animais terem sido preservados durante evolução, mesmo que possuam funções diferentes nesses animais. Tal fato pode explicar alta toxicidade da peçonha de T.serrulatus em mamíferos, mesmo que estes não sejam fonte de alimento dos escorpiões.

A serACE-like teve seus parâmetros cinéticos e bioquímicos determinados. $\mathrm{O}$ $\mathrm{K}_{m}$ estabelecido para a hidrólise de Abz-FRK(Dnp)P-OH para serACE-like $\left(\mathrm{K}_{m}=20\right.$ $\mu \mathrm{M})$ foi cerca de cinco vezes superior ao obtido para a enzima conversora de angiotensina I humana somática ( $4 \mu \mathrm{M}$ ) (ARAUJO et al., 2000), e ACE purificada de brânquias de caranguejo $(5,5 \mu \mathrm{M})$ (BERSANETTI et al., 2015) utilizando o mesmo substrato. Por outro lado, no trabalho de Araujo e colaboradores (2000) foram determinados valores cinéticos para os sítios de ACE isolados (N e C). Embora seja 
descrito que as ACEs de artrópodes se assemelham mais ao sítio $\mathrm{C}$ da enzima somática devido ao peso molecular, a comparação dos resultados com ambos os sítios também é válida. Em termos de $\mathrm{k}_{\text {cat }}$, o valor obtido no presente trabalho $\left(76,9 \mathrm{~s}^{-1}\right)$ foi superior ao estabelecido para o sítio $\mathrm{C}\left(69 \mathrm{~s}^{-1}\right)$ e para o sítio $\mathrm{N}\left(59,9 \mathrm{~s}^{-1}\right)$ na hidrólise de AbzFRK(Dnp)P-OH (ARAUJO et al., 2000). Apesar da constante de especificidade da ACE somática natural $\left(52,5 \mathrm{~s}^{-1} / \mu \mathrm{M}\right)$ sobre este FRET ser em torno de 13 vezes superior ao obtido para a serACE-like $\left(3,8 \mathrm{~s}^{-1} / \mu \mathrm{M}\right)$, a peptidase isolada neste trabalho apresenta maior proximidade com o valor obtido para o sítio $\mathrm{N}\left(17 \mathrm{~s}^{-1} / \mu \mathrm{M}\right)$ da ACE somática, pois sua eficiência catalítica é duas vezes mais baixa do que a natural e um pouco inferior ao determinado para o sítio $\mathrm{C}\left(25 \mathrm{~s}^{-1} / \mu \mathrm{M}\right)$. Por fim, essa divergência de valores pode, em parte, ser explicada pelas características individuais de cada enzima, e pela distância evolutiva destes animais, sendo que seria muito mais interessante a comparação de valores cinéticos com outras enzimas purificadas a partir de outros aracnídeos.

Com relação ao $\mathrm{pH}$, o valor ótimo de atividade foi obtido em $\mathrm{pH} 8,0$, se aproximado aos valores ideais para as medidas de atividade das metalloserrulases 3 e 4 , indicando ser uma tendência para a atividade catalítica de metalopeptidases do VTs em meios alcalinos. É significativo apontar que este dado assemelha-se ao ótimo de pH obtido para a ACE somática (ARAUJO et al., 2000) durante a clivagem de AbzFRK(Dnp)P-OH, e também para a ACE testicular de rato, onde seu pico de atividade foi obtido em pH 8,0 na clivagem de Z-Phe-His-Leu (HOHLBRUGGER et al., 1982), corroborando assim com os dados obtidos.

A atividade de serACE-like também foi avaliada em diferentes temperaturas no intervalo entre $22{ }^{\circ} \mathrm{C}$ e $42{ }^{\circ} \mathrm{C}$, sendo que não foi observado um pico ótimo pois as velocidades obtidas se mantiveram constantes. Não foram encontrados estudos de temperatura e atividade hidrolítica com ACEs purificadas de artrópodes, contudo as ACE-like de vertebrados são ativas na faixa testada, sendo que os picos ótimos de atividade encontram-se geralmente em $37{ }^{\circ} \mathrm{C}$ (BERSANETTI et al., 2015; HOHLBRUGGER et al., 1982). Por fim, essa estabilidade térmica pode sugerir uma importância desta molécula para o veneno, pois sua atividade peptidásica não seria afetada pela temperatura, permitindo sua funcionalidade na glândula, durante sua alimentação ou ainda no envenenamento. 


\subsection{Purificação das metalloserrulases: diferenciação funcional e estrutural}

Dando prosseguimento à purificação das endopeptidases do veneno de Tityus serrulatus, a cromatografia de troca iônica seguida de gel-filtração permitiu a obtenção de duas peptidases com diferentes ações sobre dinorfina 1-13 e de seu análogo fluorescente (Abz-GFLRRV-EDDnp) específico, utilizadas para o screening de atividade. O sequenciamento de peptídeos trípticos forneceu uma grande cobertura destas moléculas, sendo identificadas como metalloserrulase 3 e 4.

As metalloserrulases foram descritas em 2014 por Carmo e colegas, sendo detectadas em estudos de transcriptôma da glândula do escorpião Tityus serrulatus. Foram encontrados dez clones, sendo que a metalloserrulase 3 apresentou uma das maiores porcentagens de similaridade com a antarease (cerca de 47\%). A maioria das cisteínas encontradas nas sequências estava localizada de forma conservada, contudo as metalloserrulases 1, 2, 3, 6, 7, e 9 possuem um par de cisteína extra, o que os autores acreditam não afetar a conformação estrutural. Além disso, na árvore filogenética, as metalloserrulases 3 e 4 apresentam certa distância, sendo grupos parafiléticos (CARMO et al., 2014). Segundo os autores, os tamanhos preditos na forma ativa para a metalloserrulases 3 e 4 são $22 \mathrm{kDa}$ e $26 \mathrm{kDa}$, respectivamente.

A purificação de duas metalloserrulases no veneno de $T$. serrulatus que se diferenciam por atividade enzimática é inédita na literatura. Até o presente momento, somente a metalopeptidase denominada antarease foi purificada em venenos de Tityus, a qual foi relacionada com a pancreatite em pacientes envenenados por clivar proteínas que participam do transporte de vesículas, as VAMP (FLETCHER et al., 2010). Diferentemente do observado por Fletcher et al (2010), recentemente Zornetta e colaboradores demonstraram que a antarease recombinante não foi capaz de clivar as VAMPs em condições fisiológicas de pH e temperatura (ZORNETTA et al., 2017). Por outro lado, a antarease recombinante ativa causou neuroparalisia na junção neuromuscular de ratos e de mosca (D. melanogaster) por clivagem de proteínas na superfície da membrana pré-sináptica, impedindo a neuroexocitose, sendo que a mutante inativa não obteve o mesmo efeito (ZORNETTA et al., 2017). Sendo assim, como as metalloserrulases apresentam certa identidade com a antarease (40\% para ms 4 e $47 \%$ para ms3), e foi demonstrada neste trabalho a preferência destas enzimas por neuropeptídios, sugere-se que as metalloserrulases possam ter função semelhante à antarease. 
Por outro lado, a atribuição fisiológica destas enzimas pode também estar relacionada ao metabolismo de peptídeos humanos, principalmente de neuropeptídeos, como os membros da família do neuropeptídeo $\mathrm{Y}$ e a dinorfina 1-13, tanto em sua inativação quanto na formação de fragmentos bioativos. A dinorfina 1-13 é um exemplo especialmente interessante, pois a ação do veneno in vitro promove a liberação da Leuencefalina e, como já dito, este peptídeo pode causar estimulação de canais de potássio (INYUSHKIN, 2007) sendo, portanto, uma ação neurotóxica indireta promovida por peptidases do VTs. Vale ressaltar que apenas a metalloserrulase 3 foi capaz de gerar Leu-encefalina a partir da dinorfina 1-13.

No caso da família do NPY, foi observado que as endopeptidases purificadas são capazes de realizar a inativação destes peptídeos bioativos por produzirem somente fragmentos sem o C-terminal amidado, assim como observado no veneno total (CAJADO CARVALHO et al., 2014). Alguns dos produtos de hidrólise obtidos para as metalloserrulases também foram encontrados no estudo com o veneno total. Por exemplo, para o neuropeptídeo $\mathrm{Y}$, substrato que gerou maior número de fragmentos pela ação de ambas as metalloserrulases, sete dos produtos de hidrólise foram similares ao obtido com o veneno total, sendo dois encontrados exclusivamente na hidrólise por ms4 NPY $_{1-7}$, YPSKPDN, e NPY $1-20$, YPSKPDNPGEDAPAEDMARY), dois somente obtidos com ms3 (NPY 1-6, YPSKPD, e NPY 25-34, RHYINLITRQ) e três fragmentos formados por ambas metalloserrulases (NPY 26-34 HYINLITRQ, NPY 27-34 YINLITRQ e $\mathrm{NPY}_{28-34}$ INLITRQ). Para o polipeptídio pancreático, somente a ms3 formou fragmentos similares ao veneno total $\left(\mathrm{PP}_{1-19}\right.$ APLEPMYPGDYATHEQRAQ e PP ${ }_{1-15}$ APLEPMYPGDYATHE), e na hidrólise do peptídeo YY, tanto a ms3 (PYY 25-32

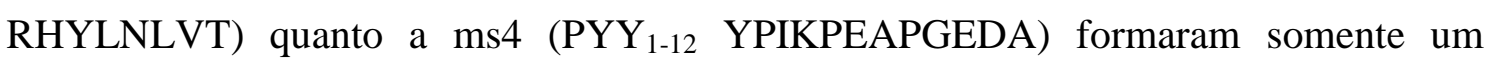
fragmento em comum com o veneno total. Contudo, tendo em vista que outros fragmentos foram obtidos pelo veneno total, é possível prever que outras peptidases presentes em VTs e que não foram isoladas nesse trabalho contribuíram para a hidrólise destes substratos. Em adendo, produtos de hidrólise não observados anteriormente com o veneno total foram obtidos com as metalloserrulases. Tal fenômeno pode ser explicado por conta da purificação das mesmas, permitindo a hidrólise preferencial destas enzimas pela ausência de competição por sítios de clivagem com outras peptidases do veneno. De qualquer forma, tal atividade é um indicativo de que estas peptidases se comportam in vitro como verdadeiras toxinas do VTs e que são componentes do veneno com potencial atividade durante o envenenamento. Tendo em vista que estes peptídeos têm reconhecida importância biológica, já descrita 
anteriormente, é possível estipular que ambas as metalloserrulases possam afetar funções pancreáticas ou até mesmo contribuir para as alterações neurológicas que ocorrem durante o envenenamento por T. serrulatus.

Foi possível observar que a metalloserrulase 4 apresenta um motivo estendido

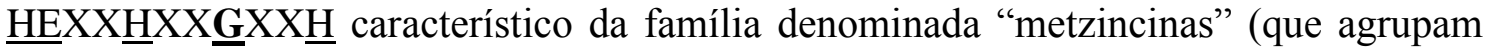
enzimas como as ADAMs, adamlisina, astacinina, entre outras). As metzincinas apresentam também um resíduo de metionina conservado, que está presente tanto na ms3 quanto na ms4. Contudo, a estrutura primária da metalloserrulase 3 revela uma

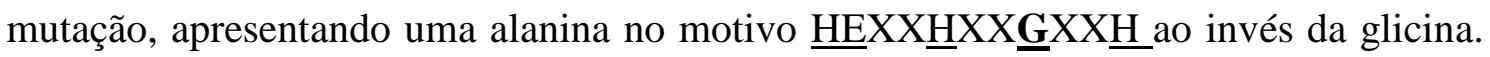
Assim, os estudos sobre modelagem teórica foram realizados, uma vez que diferenças estruturais consideráveis seriam observadas entre as ms 3 e ms4. Inesperadamente, a modelagem teórica revelou ao menos pequenas similaridades com ADAMs, o que novamente reforça a hipótese de atividade biológica durante o envenenamento destas peptidases. Contudo, é importante relembrar que esta modelagem é teórica e foi construída com base em templates de bancos de dados e, portanto, seria necessária a confirmação de tal conformação por cristalografia.

As ADAMS são peptidases importantes e conhecidas por clivarem componentes da matriz extracelular, sendo que ao menos 30 membros dessa família já foram descritas em mamíferos (GIEBELER; ZIGRINO, 2016). A ADAM-22 é membro particular desta família de enzimas, pois é exclusivamente expressa no sistema nervoso (SAGANE et al., 2005), diferentemente das outras que apresentam ampla distribuição no organismo. Estudos demonstram que a ADAM-22 é um fator crucial para o desenvolvimento do sistema nervoso periférico, sendo que camundongos com gene knockout desta peptidase têm morte prematura. Além disso, a deficiência de ADAM-22 é associada com quadros de epilepsia (SAGANE et al., 2005), indicando participação no controle motor cerebral. Sendo assim, como a ADAM-22 foi o melhor modelo teórico para a estrutura tridimensional da metalloserrulase 4 , é possível hipotetizar que esta peptidase do veneno de escorpião possa ter ação no sistema nervoso periférico, com manifestações ainda não conhecidas. Além disso, o fato da antarease recombinante ter também demonstrado interação com o sistema nervoso periférico (ZORNETTA et al., 2017), acreditamos que a ms4 possa ter alguma função neurotóxica.

No caso da metalloserrulase 3, o template teórico foi a enzima conversora de TNF-alfa. Esta peptidase é também conhecida por ADAM-17, estando envolvida em doenças inflamatórias, como na esclerose múltipla e na doença autoimune síndrome de 
Guillain-Barré (GIEBELER et al., 2016). De fato, recentemente foi demonstrada a capacidade do veneno de $T$. serrulatus em induzir o "inflamassoma" (ZOCCAL et al., 2016), e que pacientes envenenamentos apresentam níveis elevados de TNF-alfa, além de outras citocinas pró-inflamatórias (FUKUHARA et al., 2003). Sendo assim, futuramente pretendemos verificar se a metalloserrulase 3 é capaz de fazer a liberação de TNF-alfa a partir do seu precursor, contribuindo para a inflamação associada ao envenenamento.

Após a purificação, foram realizados ensaios de caracterizações físico-químicas (influência de temperatura, cátions e $\mathrm{pH}$ ) para ambas as metalloserrulases, e análises cinéticas (determinação de $\mathrm{K}_{m}, \mathrm{k}_{c a t}$ e eficiência catalítica) para a metalloserrulase 4 para a hidrólise de substratos fluorescentes análogos à dinorfina 1-13. A avaliação de tais parâmetros físico-químicos é interessante no estudo da estabilidade da enzima, além de ser possível estimar se estariam ativas durante o envenenamento, dependendo de seu comportamento nos ensaios.

Assim como anteriormente determinado para o veneno total de T. serrulatus (VENANCIO et al., 2013), o pH 8,5 foi definido como ótimo para a metalloserrulase 4. No caso de ms3, apesar do pH 8,5 ter uma influência positiva na atividade desta enzima, foi determinado o $\mathrm{pH} \mathrm{8,0} \mathrm{como} \mathrm{ideal} \mathrm{para} \mathrm{esta} \mathrm{peptidase.} \mathrm{Os} \mathrm{valores} \mathrm{de} \mathrm{pHs} \mathrm{obtidos}$ encontram-se de acordo com o pH ótimo determinado para outras metalopeptidases (3.4.24.*) de artrópodes, entre $\mathrm{pH}$ 7,0 - 9,0, segundo o banco de dados BRENDA (CHANG et al., 2015). Em adendo, estudos demonstraram que apesar dos venenos tornarem-se mais tóxicos em meios neutro-alcalinos (MARETIC; STANIC, 1954), o lúmen das glândulas de peçonhas geralmente apresentam meio mais ácido, o que provavelmente previne a degradação exacerbada de proteínas por conta das peptidases não estarem em condições ótimas para sua atividade catalítica até a injeção do veneno na presa ou acidentado (FOX; SERRANO, 2008).

A influência da temperatura da atividade catalítica das metalloserrulases indicou funcionamento destas peptidases no intervalo testado $\left(22{ }^{\circ} \mathrm{C}\right.$ a $\left.42{ }^{\circ} \mathrm{C}\right)$, assim como observado com a serACE-like. Contudo, em termos de estabilidade, o declínio de atividade das metalloserrulases em temperaturas mais elevadas provavelmente indica a desestabilização da estrutura tridimensional das enzimas. Por outro lado, esse intervalo relativamente abrangente pode ter relação com a alimentação e captura do alimento pelos escorpiões. É possível extrapolar que as peptidases estariam com atividade proteolítica estável durante o envenenamento de sua presa, como uma barata ou grilo, 
levando em conta que esses animais são pecilotérmicos, o que possibilita a atuação destas moléculas em diversas temperaturas. Por fim, em termos de envenenamento humano, os estudos de caracterização bioquímica indicam que tanto as metalloserrulases quanto a ACE-like apresentam-se ativas em condições fisiológicas de temperatura e $\mathrm{pH}\left(37^{\circ} \mathrm{C}, \mathrm{pH} 7,4\right)$.

Outro fator que comumente interfere na atividade catalítica é a presença de cátions. Com base na série de Hofmeister, certos íons podem ser classificados como cosmotrópicos, que seriam íons fortemente hidratados, estáveis, mantendo as ligações de hidrogênio e contribuindo para a estabilidade tridimensional das proteínas, ou como caotrópicos, os quais afetam negativamente as ligações de hidrogênio por gerar baixa densidade de cargas, promovendo um efeito desestabilizante em proteínas. Segundo esta série, o magnésio e o cálcio seriam classificados como cátions caotrópicos $\left(\mathrm{Mg}^{+2}>\mathrm{Ca}^{+2}\right)$, e potássio, sódio e lítio como cosmotrópicos $\left(\mathrm{K}^{+}>\mathrm{Na}^{+}>\mathrm{Li}\right)$. Sendo assim, a influência sobre a atividade das metalloserrulases está de acordo com o predito pela série de Hofmeister quanto a cátions que contribuem para uma melhor estabilidade, como o $\mathrm{K}^{+} \mathrm{e}$ o $\mathrm{Na}^{+}$, ou para a desestabilização, como o $\mathrm{Mg}^{+2}$, muito embora as concentrações de sais testadas não sejam elevadas.

Por outro lado, a inibição pela presença dos cátions bivalentes também pode estar relacionada ao íon de zinco que se encontra tetracoordenado no sítio catalítico de metalopeptidases. O átomo de zinco confere flexibilidade e dureza intermediárias necessárias para a estabilidade do sítio ativo destas enzimas. Assim, a presença de

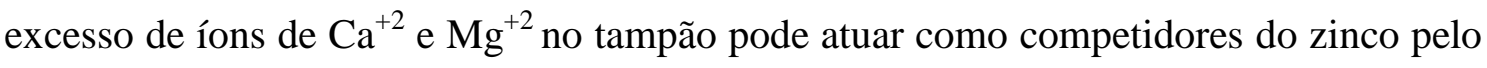
sítio ativo, provocando sua substituição, e assim desestabilizando a enzima (DUDEV; LIM, 2001).

Outro aspecto importante na caracterização de peptidases são as preferências de pontos de clivagem nos substratos, ou seja, o estudo da especificidade primária destas enzimas para a escolha e clivagem de seus substratos. Apesar de ser ideal e importante a utilização de um número maior de substratos para um estudo de especificidade mais preciso, os resultados obtidos forneceram algumas informações relevantes. Com auxílio dos substratos naturais, para ambas as peptidases observou-se uma grande preferência pelos resíduos de arginina e tirosina, independente de sua posição entre P2 e P2'. Contudo, a arginina é encontrada com maior frequência em P1 para ms4 e em P1' para ms3. Tal fato pode explicar, ao menos em parte, a liberação exclusiva de Leu-encefalina 
por ms3 a partir da dinorfina $\left(\mathrm{Y}^{1} \mathrm{G}^{2} \mathrm{G}^{3} \mathrm{~F}^{4} \mathrm{~L}^{5} \mathrm{R}^{6} \mathrm{R}^{7} \mathrm{I}^{8} \mathrm{R}^{9} \mathrm{P}^{10} \mathrm{~K}^{11} \mathrm{~L}^{12} \mathrm{~K}^{13}\right)$ com hidrólises entre as duas argininas $\operatorname{Arg}^{6} \operatorname{Arg}^{7}$ (P1-P1') e entre $\operatorname{Leu}^{5} \operatorname{Arg}^{6}$ (P1-P1').

Por outro lado, não observamos hidrólise da $\mathrm{Arg}^{9}{ }^{9}$, tanto na posição P1 quanto na posição P1'. Possivelmente isso ocorreu devido a presença de algum aminoácido específico em outra posição que impede a clivagem tanto por ms3 quanto por ms4. É interessante apontar que o resíduo de lisina não foi detectado em nenhum fragmento entre P2 e P3' mostrando que a preferência por resíduos básicos, como no caso da arginina, não extensível à lisina. Por fim, é relevante pensar que o reconhecimento do sítio entre resíduos básicos de arginina é típico de protease de processamento para a ativação de moléculas precursoras (WISE et al., 1990). Sendo assim, essas peptidases podem participar tanto da maturação de peptídeos endógenos (VERANO-BRAGA et al., 2013) quanto da formação de moléculas bioativas durante o envenenamento (CAJADO CARVALHO et al., 2014).

Levando em conta que foi observado apenas um ponto de clivagem nos substratos fluorescentes análogos da dinorfina 1-13, foi possível a realização de um estudo de especificidade mais aprofundado para a ms4. Infelizmente o mesmo não pode ser realizado com a ms3, uma vez que a enzima hidrolisou estes substratos em dois pontos de clivagem, assim como observado no peptídeo natural, a dinorfina 1-13. O substrato Abz-FLRRV-EDDnp foi definido como o melhor para a metalloserrulase 4 e, para este, a melhor constante de especificidade foi obtida em meio alcalino, provavelmente por influência do $\mathrm{pH}$ sobre a estrutura tridimensional da ms4 e não do substrato, uma vez que os aminoácidos do substrato encontram-se igualmente protonados em ambas as condições de $\mathrm{pH}$. Por outro lado, a remoção da valina do Cterminal afetou significativamente a eficiência de hidrólise provavelmente por conta dos resíduos em P2' serem importantes para o reconhecimento e/ou encaixe da ms4 e seu substrato, e sua ausência dificulta a conversão do substrato em produto. Por fim, apesar da glicina em N-terminal ter afetado moderadamente o $\mathrm{k}_{\text {cat }} / \mathrm{K}_{m}$, pode-se dizer que sua presença dificulta um pouco a velocidade de formação do produto, levando em conta que houve uma redução de $50 \%$ do $\mathrm{k}_{\text {cat }}$ em relação ao substrato sem glicina.

O teste de inibição por neutralização das atividades das metallospeptidases isoladas demonstrou uma boa inibição pelos dois antivenenos comerciais em doses menores do que o observado com o veneno total. Ainda, foi possível observar o reconhecimento por ambos os soros comerciais de banda na altura correspondente às 
metalloserrulases $(22-25 \mathrm{kDa})$ por western blot em trabalho anteriormente publicado por nosso grupo (VENANCIO et al., 2013).

A fim de facilitar a comparação, os graus de neutralização obtidos para ms3, ms4 e VTs encontram-se na Tabela 10.

Tabela 10 - Comparativos de inibição entre veneno total de Tityus serrulatus (VTs), metalloserrulase 3 e metalloserrulase 4 frente ao soro antiescorpiônico (SAE) e soro antiaracnídico (SAAr).

\begin{tabular}{llrrrrrrr}
\hline & AV & $\mathbf{1 : 1 0}$ & $\mathbf{1 :} 25$ & $\mathbf{1 : 5 0}$ & $\mathbf{1 :} 100$ & $\mathbf{1 : 2 0 0}$ & $\mathbf{1 : 5 0 0}$ & $\mathbf{1 : 1 0 0 0}$ \\
\hline VTs & SAAr & $44 \%$ & $48 \%$ & $67 \%$ & $82 \%$ & $89 \%$ & $91 \%$ & $100 \%$ \\
& SAE & $0 \%$ & $0 \%$ & $23 \%$ & $54 \%$ & $74 \%$ & $77 \%$ & $100 \%$ \\
$\mathbf{m} \mathbf{m} 3$ & SAAr & $59 \%$ & $67 \%$ & $68 \%$ & $88 \%$ & $95 \%$ & $100 \%$ & $100 \%$ \\
& SAE & $0 \%$ & $65 \%$ & $61 \%$ & $75 \%$ & $71 \%$ & $91 \%$ & $100 \%$ \\
\multirow{2}{*}{ ms4 } & SAAr & $50 \%$ & $77 \%$ & $90 \%$ & $94 \%$ & $94 \%$ & $100 \%$ & $100 \%$ \\
& SAE & $69 \%$ & $72 \%$ & $69 \%$ & $60 \%$ & $100 \%$ & $100 \%$ & $100 \%$ \\
\hline
\end{tabular}

Com auxílio deste resumo, é possível observar que o perfil de neutralização da metalloserrulase 3 se assemelha ao observado com o veneno total, com melhor inibição na presença do soro antiaracnídico nas menores doses. Por outro lado, a ms4 apresentou graus similares de neutralização tanto para SAE quanto para SAAr, sendo que seu bloqueio total foi atingido em doses moderadas. Sendo assim, pode-se dizer que o soro antiaracnídico, no geral, é capaz de neutralizar mais eficientemente ambas as metalloserrulases isoladas. Contudo, o soro escorpiônico foi especificamente melhor para neutralizar a atividade de ms4 e ser-ACE-like, corroborando com os dados já descritos por nosso grupo de que melhores títulos e melhor reconhecimento do veneno total são obtidos para SAE (VENANCIO et al., 2013).

Por fim, é interessante estabelecer um paralelo entre o envenenamento e os ensaios in vitro descritos nesse trabalho. Apesar das quantidades de veneno injetadas no paciente não serem conhecidas, segundo Pucca e colaboradores (2014), a média de proteínas totais de um veneno recém-extraído de um escorpião amarelo pode variar entre $96,4 \mu \mathrm{g}$ e $225,2 \mu \mathrm{g}$, dependendo de sua dieta e do tempo que o animal ficou em jejum (PUCCA et al., 2014). Levando esses valores em conta, e com base nas dosagens obtidas para SAE $(84 \mathrm{mg} / \mathrm{mL})$ e SAAR $(122,4 \mathrm{mg} / \mathrm{mL})$, pode-se dizer que uma ampola de antiveneno seria capaz de neutralizar tanto as metalloserrulases quanto a atividade serACE-like do veneno, pois corresponderia a uma dose igual ou acima de 1:2000 para peçonhas com altas concentrações proteicas. Por outro lado, tendo em vista que a ação 
das peptidases é geralmente rápida, e que a clivagem dos substratos foi atingida em menos de 2 horas com pequenas concentrações de veneno $(1 \mu \mathrm{g})$, é interessante levar em conta que o tempo de início do tratamento é crucial para que haja neutralização efetiva dessas moléculas, caso contrário a clivagem de peptídeos bioativos já terá sido iniciada e seus efeitos fisiológicos desencadeados. 


\section{CONCLUSÕES}

Nesse trabalho, a atividade proteolítica do veneno do escorpião amarelo Tityus serrulatus foi estudada por meio da seleção de substratos e de inibidores e pela purificação e sequenciamento de três peptidases. A partir dos resultados obtidos, foi possível concluir que:

1) Diversas peptidases estão presentes no VTs, dentre elas endopeptidases, carboxipeptidases e aminopeptidases. Para os substratos testados, foram somente detectadas metalopeptidases.

2) Essas peptidases são capazes de clivar peptídeos de mamíferos que são chave para alguns processos físiológicos, como a família do neuropeptídeo Y, a dinorfina 1-13, hemopressina, angiotensina I e bradicinina.

3) A atividade proteolítica do veneno total, tanto endopeptidásica quanto carboxipeptidásica, é parcialmente inibida pelos soros comerciais do Instituto Butantan.

4) Existem evidências transcriptômicas da presença de uma enzima conversora de angiotensina I no veneno de Tityus serrulatus e, pela primeira vez, esta molécula foi purificada.

5) A sequência de ACE-lke é também encontrada no transcriptoma de outros escorpiões do gênero Tityus e provavelmente pode estar contribuindo para o efeito de hipertensão apresentado pelas vítimas de envenenamento pela formação de Ang II e Ang III.

6) Pela primeira vez as metalloserrulases 3 e 4 foram isoladas a partir do veneno total e seus parâmetros bioquímicos determinados. Estas enzimas diferenciam-se não só pela sequência primária, mas também pela formação de diferentes produtos na clivagem de mesmos substratos como, por exemplo, a dinorfina 1-13.

7) $\mathrm{Na}$ análise de especificidade, foi possível observar a grande afinidade das metalloserrulases pelos resíduos de tirosina e arginina em P1 e/ou em P1'. Contudo, a arginina foi mais frequente na posição P1 para metalloserrulase 4 e P1' para metalloserrulase 3, o que pode explicar a liberação exclusiva de Leu-encefalina a partir de dinorfina 1-13 por ms3.

8) As metalloserrulases 3 e 4 são capazes de hidrolisar neuropeptídeos da família do neuropeptídeo Y; 
9) Tanto as metalloserrulases quanto a ACE-like apresentam pico ótimo de atividade em meio alcalino $(\mathrm{pH} 8-8,5)$. No entanto, a ACE-like apresenta maior estabilidade frente a mudanças de temperatura do que as metalloserrulases.

10) Os antivenenos comerciais apresentam bom reconhecimento das metalloserrulases, no entanto, a ms4 é melhor inibida do que ms3 e o veneno total. Para a atividade serACE-like do veneno, a neutralização total não foi atingida na maior dose. Contudo, estima-se que estas peptidases sejam neutralizadas in vivo.

11) No geral, soro antiaracnídico apresentou melhores níveis de neutralização do que o soro antiescorpiônico.

12) Por fim, os testes realizados neste trabalho podem auxiliar para uma melhor compreensão dos mecanismos de envenenamento, bem como para o desenvolvimento de técnicas in vitro para o estudo do veneno de Tityus serrulatus. 


\section{REFERÊNCIAS*}

ABROUG, F., et al. Serotherapy in scorpion envenomation: a randomised controlled trial. Lancet, v. 354, n. 9182, p. 906-909, 1999.

ALMEIDA, D. D., et al. Profiling the resting venom gland of the scorpion Tityus stigmurus through a transcriptomic survey. BMC Gen., v. 13, p. 362, 2012.

ALVARENGA, É. R., et al. Transcriptome analysis of the Tityus serrulatus scorpion venom gland. Open. J. Genet., v.2, p 210-220, 2012.

ARAUJO, M. C., et al. Peptidase specificity characterization of C- and N-terminal catalytic sites of angiotensin I-converting enzyme. Biochemistry, v. 39, n. 29, p. 8519$8525,2000$.

BAWASKaR, H. S.; BAWASKAR, P. H. Scorpion sting: update. J. Assoc. Phys. India., v. 60, p. 46-55, 2012.

BERNSTEIN, K. E., et al. A modern understanding of the traditional and nontraditional biological functions of angiotensin-converting enzyme. Pharmacol. Rev., v. 65, n. 1, p. $1-46,2013$.

BERSANETTI, P. A., et al. Characterization of angiotensin I-converting enzyme from anterior gills of the mangrove crab Ucides cordatus. Int. J. Biol. Macromol., v. 74, p. 304-309, 2015.

BLAIS, P.-A., et al. Hypotensive effects of hemopressin and bradykinin in rabbits, rats and mice: a comparative study. Peptides, v. 26, n. 8, p. 1317-1322, 2005.

BORTOLUZZI, L. R., et al. Notes on the occurrence of Tityus serrulatus Lutz \& Mello, 1922 (Scorpiones, Buthidae) in the Western areas of Rio Grande do Sul, Brazil. Biota Neotropica, v. 7, n. 3, p. 357-359, 2007.

BOYER, L. V., et al. Antivenom for critically ill children with neurotoxicity from scorpion stings. N. Engl. J. Med., v. 360, n. 20, p. 2090-2098, 2009.

BOYER, L. V., et al. Safety of intravenous equine F(ab')2: insights following clinical trials involving 1534 recipients of scorpion antivenom. Toxicon, v. 76, p. 386-393, 2013.

BRAZÓN, J., et al. Fibrin(ogen)olytic enzymes in scorpion (Tityus discrepans) venom. Comp. Biochem. Physiol. B. Biochem. Mol. Biol., v. 168, p. 62-69, 2014.

BUCARETCHI, F., et al. Clinical consequences of Tityus bahiensis and Tityus serrulatus scorpion stings in the region of Campinas, southeastern Brazil. Toxicon, v. 89, p. 17-25, 2014.

*De acordo com: ASSOCIAÇÃO BRASILEIRA DE NORMAS TÉCNICAS. NBR 6023: informação e documentação: referências: elaboração. Rio de Janeiro, 2002 
CAJADO CARVALHO, D., et al. Neuropeptide Y family-degrading metallopeptidases in the Tityus serrulatus venom partially blocked by commercial antivenoms. Toxicol. Sci., v. 142, n. 2, p. 418-426, 2014.

CALISKAN, F., et al. A preliminary study for the detection of gelatinolytic proteases from the scorpion Androctonus crassicauda (Turkish Black Scorpion) venom. Turk. J. Biochem., v. 34, n. 3, p. 148-153, 2009.

CAMARGO, A. C., et al. Bradykinin-potentiating peptides: beyond captopril. Toxicon, v. 59, n. 4, p. 516-523, 2012.

CANDIANO, G., et al. Blue silver: a very sensitive colloidal Coomassie G-250 staining for proteome analysis. Electrophoresis, v. 25, n. 9, p. 1327-1333, 2004.

CARMO, A. O., et al. Molecular and functional characterization of metalloserrulases, new metalloproteases from the Tityus serrulatus venom gland. Toxicon, v. 90, p. 45-55, 2014.

CASEWELL, N. R., et al. Complex cocktails: the evolutionary novelty of venoms. Trends Ecol. Evol., v. 28, n. 4, p. 219-229, 2013.

CHANG, A., et al. BRENDA in 2015: exciting developments in its 25th year of existence. Nucleic. Acids. Res., v. 43, p. 439-446, 2015.

CHIPPAUX, J. P.; GOYFFON, M. Epidemiology of scorpionism: a global appraisal. Acta. Trop., v. 107, n. 2, p. 71-79, 2008.

CHIPPAUX, J. P. Emerging options for the management of scorpion stings. Drug Des. Devel. Ther., v. 6, n., p. 165-173, 2012.

COLAERT, N., et al. Improved visualization of protein consensus sequences by iceLogo. Nat. Methods., v. 6, n. 11, p. 786-787, 2009.

COLOGNA, C. T., et al. Tityus serrulatus scorpion venom and toxins: an overview. Protein. Pept. Lett., v. 16, n. 8, p. 920-932, 2009.

CONLON, J. M. The origin and evolution of peptide YY (PYY) and pancreatic polypeptide (PP). Peptides, v. 23, n. 2, p. 269-278, 2002.

CORDEIRO, F. A., et al. Arachnids of medical importance in Brazil: main active compounds present in scorpion and spider venoms and tick saliva. J. Venom. Anim. Toxins Incl. Trop. Dis., v. 21, n., p. 24, 2015.

DALE, C. S., et al. Antinociceptive action of hemopressin in experimental hyperalgesia. Peptides, v. 26, n. 3, p. 431-436, 2005.

DANI, M. P., et al. Antibacterial and proteolytic activity in venom from the endoparasitic wasp Pimpla hypochondriaca (Hymenoptera: Ichneumonidae). J. Insect Physiol., v. 49, n. 10, p. 945-954, 2003.

DE OLIVEIRA, U. C., et al. The transcriptome recipe for the venom cocktail of Tityus bahiensis scorpion. Toxicon, v. 95, p. 52-61, 2015. 
DE REZENDE, N. A., et al. Is the severity of Tityus serrulatus scorpion envenoming related to plasma venom concentrations? Toxicon, v. 34, n. 7, p. 820-823, 1996.

DEQUATTRO, V.; CHAN, S. Raised plasma-catecholamines in some patients with primary hypertension. Lancet, v. 1, n. 7755, p. 806-809, 1972.

DÍAZ-GARCÍA, A., et al. Enzymatic analysis of venom from Cuban scorpion Rhopalurus junceus. J. Venom Res., v. 6, p. 11-18, 2015.

DIZ, D. I. Another chapter in the understanding of angiotensin-catecholamine interactions relevant to blood pressure control. Exp. Physiol., v. 99, n. 12, p. 1595 1596, 2014.

DUDEV, T.; LIM, C. Metal selectivity in metalloproteins: $\mathrm{Zn}^{2+} \mathrm{vs}_{\mathrm{Mg}^{2+}}$. J. Phys. Chem. B., v. 105, n. 19, p. 4446-4452, 2001.

DUZZI, B., et al. [des-Arg(1)]-Proctolin: A novel NEP-like enzyme inhibitor identified in Tityus serrulatus venom. Peptides, v. 80, p. 18-24, 2016.

EL-DEEK, S. E., et al. Role of some vasoactive mediators in scorpion envenomed children: Possible relation to envenoming outcome. Toxicon, v. 127, p. 77-84, 2017.

ESTRADA-GÓMEZ, S., et al. Venom from Opisthacanthus elatus scorpion of Colombia, could be more hemolytic and less neurotoxic than thought. Acta. Trop., v. 153, p. 70-78, 2016.

FERRARIO, C. M. Angiotensin-converting enzyme 2 and angiotensin-(1-7): an evolving story in cardiovascular regulation. Hypertension, v. 47, n. 3, p. 515-521, 2006.

FERREIRA, M. G., et al. Toxicity of crude and detoxified Tityus serrulatus venom in anti-venom-producing sheep. J. Vet. Sci., v. 17, n. 4, p. 467-477, 2016.

FLETCHER, M. D., et al. Morphological studies by light and electron microscopy of pancreatic acinar cells under the effect of Tityus serrulatus venom. Cell Tissue Res., v. 278, n. 2, p. 255-264, 1994.

FLETCHER, P. L., et al. Vesicle-associated membrane protein (VAMP) cleavage by a new metalloprotease from the Brazilian scorpion Tityus serrulatus. J. Biol. Chem., v. 285, n. 10, p. 7405-7416, 2010.

FOX, J. W.; SERRANO, S. M. Exploring snake venom proteomes: multifaceted analyses for complex toxin mixtures. Proteomics, v. 8, n. 4, p. 909-920, 2008.

FOX, J. W.; SERRANO, S. M. Insights into and speculations about snake venom metalloproteinase (SVMP) synthesis, folding and disulfide bond formation and their contribution to venom complexity. FEBS J., v. 275, n. 12, p. 3016-3030, 2008.

FOX, R. C.; SCOTT, C. S. First evidence of a venom delivery apparatus in extinct mammals. Nature. v. 435, n. 7045, p. 1091-1093, 2005. 
FREIRE-MAIA, L.; CAMPOS, J. Pathophysiology and treatment of scorpion poisoning. In: Ownby, C. e Odell, G. (Ed.). Natural toxins, characterization, pharmacology and therapeutics. Oxford: Pergamon Press, 1989, p.139-159.

FUKUHARA, Y. D., et al. Increased plasma levels of IL-1beta, IL-6, IL-8, IL-10 and TNF-alpha in patients moderately or severely envenomed by Tityus serrulatus scorpion sting. Toxicon, v. 41, n. 1, p. 49-55, 2003.

GIEBELER, N.; ZIGRINO, P. A Disintegrin and Metalloprotease (ADAM): Historical Overview of Their Functions. Toxins (Basel), v. 8, n. 4, p. 122, 2016.

GONG, E., et al. The birdlike raptor Sinornithosaurus was venomous. Proc. Natl. Acad. Sci. U. S. A., v. 107, n. 2, p. 766-768, 2010.

GRUNDEMAR, L.; HÅKANSON, R. Effects of various neuropeptide Y/peptide YY fragments on electrically-evoked contractions of the rat vas deferens. Br. J. Pharmacol., v. 100, n. 1, p. 190-192, 1990.

GUERRA, C. M., et al. Analysis of variables related to fatal outcomes of scorpion envenomation in children and adolescents in the state of Minas Gerais, Brazil, from 2001 to 2005. J. Pediatr. (Rio J.)., v. 84, n. 6, p. 509-515, 2008.

GUIDINE, P. A., et al. Brainstem structures are primarily affected in an experimental model of severe scorpion envenomation. Toxicol. Sci., v. 137, n. 1, p. 147-157, 2014.

HAGAMAN, J. R., et al. Angiotensin-converting enzyme and male fertility. Proc. Natl. Acad. Sci. U.S.A., v. 95, n. 5, p. 2552-2557, 1998.

HANNA, S. L., et al. Comparison of proteins expressed by Pseudomonas aeruginosa strains representing initial and chronic isolates from a cystic fibrosis patient: an analysis by 2-D gel electrophoresis and capillary column liquid chromatography-tandem mass spectrometry. Microbiology, v. 146 ( Pt 10), n., p. 2495-2508, 2000.

HARRISON, C.; ACHARYA, K. R. ACE for all - a molecular perspective. J. Cell. Commun. Signal., v. 8, n. 3, p. 195-210, 2014.

HIGA, A., et al. Degradation of $\mathrm{A} \alpha$ and $\mathrm{B} \beta$ chains from bovine fibrinogen by serine proteases of the Amazonian scorpion Brotheas amazonicus. BMC Proc., p. P12, 2014

HIRATA, I. Y., et al. Internally quenched fluorogenic protease substrates: Solid-phase synthesis and fluorescence spectroscopy of peptides containing orthoaminobenzoyl/dinitrophenyl groups as donor-acceptor pairs. Lett. Pep. Sci., v. 1, p. 299-308, 1994.

HOHLBRUGGER, G., et al. Angiotensin I converting enzyme in rat testis, epididymis and vas deferens under different conditions. J. Reprod. Fertil., v. 65, n. 1, p. 97-103, 1982.

HORTA, C. C., et al. Molecular, immunological, and biological characterization of Tityus serrulatus venom hyaluronidase: new insights into its role in envenomation.

PLoS Negl. Trop. Dis., v. 8, n. 2, p. e2693, 2014. 
INYUSHKIN, A. N. Effects of leucine-enkephalin on potassium currents in neurons in the rat respiratory center in vitro. Neurosci. Behav. Physiol., v. 37, n. 7, p. 739-746, 2007.

ISAAC, R., et al. A novel peptide-processing activity of insect peptidyl-dipeptidase A (angiotensin I-converting enzyme): the hydrolysis of lysyl-arginine and arginyl-arginine from the C-terminus of an insect prohormone peptide. Biochem. J., v. 330, n. 1, p. 61$65,1998$.

ISBISTER, G. K., et al. Antivenom treatment in arachnidism. J. Toxicol. Clin. Toxicol., v. 41, n. 3, p. 291-300, 2003.

ISMAIL, M. The scorpion envenoming syndrome. Toxicon, v. 33, n. 7, p. 825-858, 1995.

KELLEY, L. A.; STERNBERG, M. J. Protein structure prediction on the Web: a case study using the Phyre server. Nat. Protoc., v. 4, n. 3, p. 363-371, 2009.

KUKKOLA, P. J., et al. Differential structure-activity relationships of phosphoramidon analogues for inhibition of three metalloproteases: endothelin-converting enzyme, neutral endopeptidase, and angiotensin-converting enzyme. J. Cardiovasc. Pharmacol., v. 26 Suppl 3, p. S65-68, 1995.

KUMAR, S., et al. MEGA7: Molecular Evolutionary Genetics Analysis version 7.0 for bigger datasets. Mol. Biol. Evol., v. 33, n. 7, p. 1870-1874, 2016.

LEMEIRE, E., et al. Angiotensin-converting enzyme in Spodoptera littoralis: molecular characterization, expression and activity profile during development. Insect Biochem. Mol. Biol., v. 38, n. 2, p. 166-175, 2008.

LOURENÇO, W. R. What do we know about some of the most conspicuous scorpion species of the genus Tityus? A historical approach. J. Venom Anim. Toxins Incl. Trop. Dis., v. 21, p. 20, 2015.

MA, B., et al. PEAKS: powerful software for peptide de novo sequencing by tandem mass spectrometry. Rapid. Commun. Mass Spectrom., v. 17, n. 20, p. 2337-2342, 2003.

MANZOLI-PALMA, M., et al. Insects as biological models to assay spider and scorpion venom toxicity. J. Venom Anim. Toxins Incl. Trop. Dis., v. 9, n. 2, p. 174$185,2003$.

MARC, Y.; LLORENS-CORTES, C. The role of the brain renin-angiotensin system in hypertension: implications for new treatment. Prog. Neurobiol., v. 95, n. 2, p. 89-103, 2011.

MARETIC, Z.; STANIC, M. The health problem of arachnidism. Bull World Health Organ. v. 11, n. 6, p. 1007-1022, 1954.

MINISTÉRIO DA SAÚDE. Manual de controle de escorpiões, 2009. 
MORGENSTERN, D., et al. The tale of a resting gland: transcriptome of a replete venom gland from the scorpion Hottentotta judaicus. Toxicon, v. 57, n. 5, p. 695-703, 2011.

MORRISSEY, J. H. Silver stain for proteins in polyacrylamide gels: a modified procedure with enhanced uniform sensitivity. Anal Biochem, v. 117, n. 2, p. 307-310, 1981.

MURTHY, K. R. K.; VAKIL, A. E. Elevation of plasma angiotensin levels in dogs by Indian red scorpion (Buthus tamulus) venom \& its reversal by administration of insulin+tolazoline. Indian J Med Res, v. 88, p. 376-379, 1988.

MURTHY, K. R. K. Hypertension, Autonomic Storm, Increased Counter Regulatory Hormones and Suppressed Insulin in Acute Myocarditis in Scorpion Envenoming Syndrome. World J Cardiovasc Dis., v. 4, p. 189-210, 2014.

NUNAN, E. A., et al. Lethal effect of the scorpion Tityus serrulatus venom: comparative study on adult and weanling rats. Braz. J. Pharm. Sci., v. 37, n. 1, p. 3944, 2001.

NUNAN, E. A., et al. Age effects on the pharmacokinetics of tityustoxin from Tityus serrulatus scorpion venom in rats. Braz J Med Biol Res., v. 37, n. 3, p. 385-390, 2004.

ORTIZ, E., et al. Antarease-like Zn-metalloproteases are ubiquitous in the venom of different scorpion genera. Biochim Biophys Acta., v. 1840, n. 6, p. 1738-1746, 2014.

PIERAMICO, O., et al. Interdigestive cycling in chronic pancreatitis: altered coordination among pancreatic secretion, motility, and hormones. Gastroenterology, v. 109, n. 1, p. 224-230, 1995.

PUCCA, M. B., et al. Serrumab: a human monoclonal antibody that counters the biochemical and immunological effects of Tityus serrulatus venom. J. Immunotoxicol., v. 9, n. 2, p. 173-183, 2012.

PUCCA, M. B., et al. Serrumab: a novel human single chain-fragment antibody with multiple scorpion toxin-neutralizing capacities. J. Immunotoxicol., v. 11, n. 2, p. 133$140,2014$.

PUCCA, M. B., et al. Influence of post-starvation extraction time and prey-specific diet in Tityus serrulatus scorpion venom composition and hyaluronidase activity. Toxicon, v. 90, p. 326-336, 2014.

RAWLINGS, N. D., et al. MEROPS: the peptidase database. Nucleic. Acids Res., v. 38, p. D227-D233, 2010.

RAWLINGS, N. D., et al. MEROPS: the database of proteolytic enzymes, their substrates and inhibitors. Nucleic. Acids Res., v. 42, p. D503-509, 2014.

REAUX, A., et al. Angiotensin III: a central regulator of vasopressin release and blood pressure. Trends Endocrinol. Metab., v. 12, n. 4, p. 157-162, 2001. 
RIOLI, V., et al. Novel natural peptide substrates for endopeptidase 24.15, neurolysin, and angiotensin-converting enzyme. J. Biol Chem., v. 278, n. 10, p. 8547-8555, 2003.

SAFAVI-HEMAMI, H., et al. High molecular weight components of the injected venom of fish-hunting cone snails target the vascular system. J. Proteomics., v. 91, p. 97-105, 2013.

SAGANE, K., et al. Ataxia and peripheral nerve hypomyelination in ADAM22deficient mice. BMC Neurosci., v. 6, p. 33, 2005.

SALZET, M. Neuroimmunology of opioids from invertebrates to human. Neuro. Endocrinol. Lett., v. 22, n. 6, p. 467-474, 2001.

SANTOS, R. M. M. D. Contribuição da FUNED para a produção de soros antivenenos e antitóxicos no Brasil. Rev. Min. Saúde Pub., v. 5, n. 6, p. 13-19, 2005.

SCHECHTER, I.; BERGER, A. On the size of the active site in proteases. I. Papain. Biochem. Biophys. Res. Commun., v. 27, n. 2, p. 157-162, 1967.

SERAFINI, G., et al. The role of neuropeptides in suicidal behavior: a systematic review. Biomed. Re.s Int., v. 2013, p. 687575, 2013.

SEWALD, N.; JAKUBKE, H. D. Biologically Active Peptides. In: Sewald, N., Jakubke, H.D. (Ed.). Peptides: Chemistry and Biology. UK: Wiley, 2003. v.1, p.61-134.

SIFI, A., et al. Role of angiotensin II and angiotensin type-1 receptor in scorpion venom-induced cardiac and aortic tissue inflammation. Exp. Mol. Pathol., v. 102, n. 1, p. 32-40, 2017.

SILVA, S., et al. Escorpiões, Aranhas e Serpentes: aspectos gerais e espécies de interesse médico no estado de Alagoas. Maceió: Eufal.[livro online]. 2005.

SISTEMA DE INFORMAÇÃO DE AGRAVOS DE NOTIFICAÇÃO DE ANIMAIS PEÇONHENTOS (SINAN). Acidente Por Animais Peçonhentos - Notificações Registradas No Sistema De Informação De Agravos De Notificação - Brasil, 2017.

SOARES, M. R., et al. [Scorpionism in Belo Horizonte, MG: a retrospective study]. Rev. Soc. Bras. Med. Trop., v. 35, n. 4, p. 359-363, 2002.

SOFER, S., et al. Scorpion envenomation and antivenom therapy. J. Pediatr., v. 124, n. 6, p. 973-978, 1994.

STOLL, V. S.; BLANCHARD, J. S. Buffers: principles and practice. Methods Enzymol., v. 182, p. 24-38, 1990.

TAN, N. H.; PONNUDURAI, G. Comparative study of the enzymatic, hemorrhagic, procoagulant and anticoagulant activities of some animal venoms. Comp. Biochem. Physiol. C., v. 103, n. 2, p. 299-302, 1992.

TASHIMA, A. K., et al. Peptidomics of three Bothrops snake venoms: insights into the molecular diversification of proteomes and peptidomes. Mol. Cell. Proteomics., v. 11, n. 11, p. 1245-1262, 2012. 
TEIXEIRA, A. L., et al. Evidence for a direct action of Tityus serrulatus scorpion venom on the cardiac muscle. Toxicon, v. 39, n. 5, p. 703-709, 2001.

TENÓRIO, H. E. A., et al. Angiotensin processing activities in the venom of Thalassophryne nattereri. Toxicon, v. 98, p. 49-53, 2015.

TISCORNIA, O. M., et al. Pancreatic polypeptide: a review of its involvement in neuroendocrine reflexes, islet-acinar interactions and ethanol-evoked physiopatologic pancreatic gland changes. Acta Gastroenterol. Latinoam., v. 45, n. 2, p. 155-164, 2015.

VENANCIO, E. J., et al. Enzymatic properties of venoms from Brazilian scorpions of Tityus genus and the neutralisation potential of therapeutical antivenoms. Toxicon, v. 69, p. 180-190, 2013.

VERANO-BRAGA, T., et al. From bradykinin-potentiating peptides to hypotensins: more than four decades of research. In: UFMG (Ed.). Animal toxins: state of the art. Perspectives in health and biothecnology. Belo Horizonte, 2009, p.235-247.

VERANO-BRAGA, T., et al. Moving pieces in a venomic puzzle: unveiling posttranslationally modified toxins from Tityus serrulatus. J. Proteome Res., v. 12, n. 7, p. 3460-3470, 2013.

WILLIAMS, S. C. Scorpion bionomics. Annu. Rev. Entomol., v. 32, p. 275-295, 1987.

WISE, R. J., et al. Expression of a human proprotein processing enzyme: correct cleavage of the von Willebrand factor precursor at a paired basic amino acid site. Proc. Natl. Acad. Sci. U.S.A., v. 87, n. 23, p. 9378-9382, 1990.

YATES, C. J., et al. Molecular and thermodynamic mechanisms of the chloridedependent human angiotensin-I-converting enzyme (ACE). J. Biol. Chem., v. 289, n. 3, p. 1798-1814, 2014.

ZHANG, J., et al. PEAKS DB: de novo sequencing assisted database search for sensitive and accurate peptide identification. Mol. Cell. Proteomics., v. 11, n. 4, p. M111.010587, 2012.

ZOCCAL, K. F., et al. Opposing roles of LTB4 and PGE2 in regulating the inflammasome-dependent scorpion venom-induced mortality. Nat. Commun., v. 7, p. 10760, 2016.

ZORNETTA, I., et al. Electrophysiological Characterization of the Antarease Metalloprotease from Tityus serrulatus Venom. Toxins (Basel), v. 9, n. 3, p., 2017. 


\section{ANEXO A}

\section{Lista de produções bibliográficas}

\section{Relacionados aos resultados do doutorado}

1 - CAJADO CARVALHO, D.; KUNIYOSHI, A.K.; KODAMA, R.T.; OLIVEIRA, A.K.; SERRANO, S.M.; TAMBOURGI, D.V.; PORTARO, F. V. Neuropeptide Y family-degrading metallopeptidases in the Tityus serrulatus venom partially blocked by commercial antivenoms. Toxicol Sci. 2014 Dec;142(2):418-26. doi: 10.1093/toxsci/kfu193. Epub 2014 Sep 19.

2- CAJADO CARVALHO, D.; KUNIYOSHI, A.K.; DUZZI, B.; IWAI, L.K.; OLIVEIRA, U.C.; JUNQUEIRA DE AZEVEDO, I.L.; KODAMA, R.T.; PORTARO, F.V. Insights into the Hypertensive Effects of Tityus serrulatus Scorpion Venom: Purification of an Angiotensin-Converting Enzyme-Like Peptidase. Toxins (Basel). 2016 Nov 24;8(12). pii: E348.

\section{Manuscrito em redação}

A) CAJADO-CARVALHO, D.; OLIVEIRA, I.C.S.; SILVA, C.C.F., KODAMA, R.T., DUZZI, B., KUNIYOSHI, A.K.; PORTARO, F.V. A proteolytic outlook of scorpion venoms: isolation and biochemical characterization of metalloserrulase 3 and 4 from Tityus serrulatus venom.

\section{Colaborações}

3- RODRIGUEZ, R.V.; DORCE, V.A.; DE FREITAS, L.A.; DORCE, A.L.; LEBRUN, I.; SOBRAL, A.C.; PORTARO, F.C.; KUNIYOSHI, A.K.; CARVALHO, D.C.; NENCIONI, A.L. Intrahippocampal injection of TsTX-I increases the levels of INF- $\gamma$ in the cerebral tissue but not the levels of glutamate. Toxicon. 2015 Sep;103:155-9. doi: 10.1016/j.toxicon.2015.07.006. Epub 2015 Jul 7.

4- DUZZI, B.; CAJADO-CARVALHO, D.; KUNIYOSHI, A.K.; KODAMA, R.T.; GOZZO, F.C.; FIORAMONTE, M.; TAMBOURGI, D.V.; PORTARO, F.V.; RIOLI, V. [des-Arg(1)]-Proctolin: A novel NEP-like enzyme inhibitor identified in Tityus serrulatus venom. Peptides. 2016 Jun;80:18-24. doi: 10.1016/j.peptides.2015.05.013. Epub 2015 Jun 6 
5- KODAMA, R.T.; CAJADO-CARVALHO, D.; KUNIYOSHI, A.K.; KITANO, E.S.; TASHIMA, A.K.; BARNA, B.F.; TAKAKURA, A.C.; SERRANO, S.M.; DIAS-DASILVA, W.; TAMBOURGI, D.V.; PORTARO, F.V. New proline-rich oligopeptides from the venom of African adders: Insights into the hypotensive effect of the venoms. Biochim Biophys Acta. 2015 Jun;1850(6):1180-7. doi: 10.1016/j.bbagen.2015.02.005. Epub 2015 Feb 14.

6- KUNIYOSHI, A.K.; KODAMA, R.T.; MORAES, L.H.F.; DUZZI, B.; IWAI, L.K.; LIMA, I.F.; CAJADO-CARVALHO, D.; PORTARO, F.V. In vitro cleavage of bioactive peptides by peptidases from Bothrops jararaca venom and its neutralization by bothropic antivenom produced by Butantan Institute: major contribution of serine peptidases. Toxicon - aceito em 21 de julho de 2017.

\section{Manuscrito submetido a Toxins}

B-CAJADO CARVALHO, D.; SILVA, J.G.; KUNIYOSHI, A.K.; CARNEIRO, P.S.; PAES LEME, A.F.; PAULETTI, B.A.; MARENGO, E.B.; PORTARO, F.V. Tityus serrulatus scorpion venom: In vitro tests and its correlation with in vivo lethal dose assay 
Article

\title{
Insights into the Hypertensive Effects of Tityus serrulatus Scorpion Venom: Purification of an Angiotensin-Converting Enzyme-Like Peptidase
}

\author{
Daniela Cajado-Carvalho ${ }^{1}$, Alexandre Kazuo Kuniyoshi ${ }^{1}$, Bruno Duzzi ${ }^{1}$, Leo Kei Iwai ${ }^{2}$, Úrsula \\ Castro de Oliveira ${ }^{2}$, Inácio de Loiola Meirelles Junqueira de Azevedo ${ }^{2}$, \\ Roberto Tadashi Kodama ${ }^{1}$ and Fernanda Vieira Portaro ${ }^{1, *}$ \\ 1 Immunochemistry Laboratory, Butantan Institute, São Paulo CEP 05503-900, SP, Brazil; \\ daniela.carvalho@butantan.gov.br (D.C.-C.); alexandre.kuniyoshi@butantan.gov.br (A.K.K.); \\ bruno.duzzi@butantan.gov.br(B.D.); pararoberval@gmail.com(R.T.K.) \\ 2 Special Laboratory for Applied Toxinology, Butantan Institute/Center of Toxins, Immune-Response and Cell \\ Signaling (CeTICS), São Paulo CEP 05503-900, SP, Brazil; leo.iwai@butantan.gov.br (L.K.I.); \\ ursula.oliveira@butantan.gov.br (Ú.C.d.O.); inacio.azevedo@butantan.gov.br (I.d.L.M.J.d.A.) \\ * Correspondence: fernanda.portaro@butantan.gov.br;Tel.: +55-11-2627-9716
}

Academic Editor: Ronald A. Jenner

Received: 7 October 2016; Accepted: 16 November 2016; Published: 24 November 2016

\begin{abstract}
The number of cases of envenomation by scorpions has grown significantly in Brazil since 2007, with the most severe cases being caused by the Tityus serrulatus scorpion. Although envenomed patients mostly suffer neurotoxic manifestations, other symptoms, such as hypertension, cannot be exclusively attributed to neurotoxins. Omics analyses have detected plentiful amounts of metalloproteases in T. serrulatus venom. However, the roles played by these enzymes in envenomation are still unclear. Endeavoring to investigate the functions of scorpion venom proteases, we describe here for the first time an Angiotensin I-Converting Enzyme-like peptidase (ACE-like) purified from T. serrulatus venom. The crude venom cleaved natural and fluorescent substrates and these activities were inhibited by captopril. Regarding the serum neutralization, the scorpion antivenom was more effective at blocking the ACE-like activity than arachnid antivenom, although neither completely inhibited the venom cleavage action, even at higher doses. ACE-like was purified from the venom after three chromatographic steps and its identity was confirmed by mass spectrometric and transcriptomic analyses. Bioinformatics analysis showed homology between the ACE-like transcript sequences from Tityus spp. and human testis ACE. These findings advance our understanding of

T. serrulatus venom components and may improve treatment of envenomation victims, as ACE-like may contribute to envenomation symptoms, especially the resulting hypertension.
\end{abstract}

Keywords: ACE-like; Tityus serrulatus venom; proteases; antivenom; hypertension

\section{Introduction}

According to Brazil's Ministry of Health, since 2007 scorpion stings have been the main form of envenomation by animals in this country. An epidemiological survey conducted by the Ministry of Health shows that, between 2010 and 2013, cases of scorpion envenomation represent $49 \%$ of poisonings by venomous animals in Brazil, surpassing those by snakes $(17 \%)$ and spiders $(18.5 \%)$. This scenario is mainly attributed to the proliferation of Tityus serrulatus scorpions, synanthropic animals that reproduce by parthenogenesis [1] and whose potent venom contributes to the occurrence of critical clinical envenomation. Thus, T. serrulatus venom (Tsv) is one of the most studied Brazilian scorpion venoms [2]. 
Neurotoxins in Tsv cause most of the envenomation symptoms by promoting neurotransmitter release from the autonomic nervous system and the adrenal medulla onto several organs [3]. These events result in clinical manifestations such as restlessness, excessive salivation, lacrimation, hypertension followed by hypotension, heart failure, and cardiogenic shock, among others. Not all symptoms, however, are attributed to a direct action of specific neurotoxins on organs [4], and recent studies suggest that other molecules may contribute to these effects [5-7]. Metallopeptidases, hyaluronidase, biogenic amines, antimicrobial peptides (AMP), and other oligopeptides are also present in Tsv [7-9]; however, the role of these molecules in envenomation is still unclear.

Peptidases present in animal venoms often play an important role in the envenomation syndrome, as they can cleave proteins and peptides that are key factors for physiological systems. For instance, in snake venoms, serine peptidases can affect the coagulation cascade and kallikrein-kinin system, while metallopeptidases target components of blood coagulation and platelet aggregation, both resulting in an imbalance of the hemostatic system $[10,11]$. Although snake venom peptidases are the most studied, due to their abundance, proteolytic activity has recently been described in jellyfish [12], cone snail [13], wasp [14], spider [15], and scorpion [16] venoms.

Thus far, metallopeptidases and hyaluronidases comprise the only classes of enzymes purified and with their functional activities determined in Tityus spp. venoms [6,9], although transcriptomic studies have identified other classes of enzymes as well [8,17]. Studies from our group have shown that Tsv proteases cleave mammal peptides in vitro, and that this activity is inhibited by high concentrations of commercially available antivenoms used in the treatment of envenomed patients in Brazil $[16,18]$. Moreover, endopeptidases, aminopeptidases, and carboxypeptidases that cleave endogenous peptides from the Tsv and inactivate human bioactive peptides have been detected $[18,19]$. One of these, antarease, is a metallopeptidase ubiquitous in the venom of scorpions of family Buthidae [20], to whose action the pancreatitis observed in mice after venom injection is attributed [21].

The human somatic angiotensin-I converting enzyme (sACE, EC 3.4.15.1) is a dipeptidyl carboxypeptidase that plays a crucial role in blood pressure regulation through the renin-angiotensin (RAS) and kalikrein-kinin (KKS) systems. sACE converts angiotensin I into angiotensin II in RAS, and inactivates bradykinin in KKS, leading to blood pressure increase. sACE has two highly similar, independent catalytic domains, the $\mathrm{N}$ - and $\mathrm{C}$-terminal domains. Although both have proteolytic activity, regulation of blood pressure mostly depends on the $C$-terminal domain, as it is responsible for producing angiotensin II [22]. A smaller isoform of SACE is also present in mammals: known as testicular ACE (tACE), it contains only the C-terminal domain [23,24]. The same gene encodes both somatic and testicular ACE $[23,25]$ but tACE is only found after puberty in male germinal cells, where it participates in sperm maturation, in contrast with the constant and wide expression of $\mathrm{SACE}$ that acts all over the body[26].

ACE-like enzymes are highly conserved, having also been detected in insects, where they play a role in feeding, reproduction, and the production of peptide hormones and neurotransmitters [27]. Also, functional ACE-like activity was detected in animal venoms of the fish-hunting cone snail [13], vampire snail [28], and solitary endoparasitic wasp [14]. In scorpions, ACE-like peptidases were detected by transcriptome analysis in Hottentotta judaicus [29], Tityus stigmurus [30], and Tityus bahiensis [17] venoms.

Here we describe and characterize for the first time an Angiotensin I-Converting Enzyme-like peptidase activity in Tityus serrulatus venom and the evaluation of commercially available antivenoms to neutralize it. We used proteolytic activity assays to detect an ACE-like peptidase, then purified and confirmed its identity by tryptic digestion/mass spectrometric and transcriptomic analysis.

This report may contribute to our understanding of the role of proteases from scorpion venoms in the envenomation process, as an ACE-like peptidase may contribute to the hypertension observed in human victims. 


\section{Results}

\subsection{FRET Substrates Specific for Carboxy-and Endopeptidases on Tsv}

We first evaluated Tsv activity with peptidase inhibitors, using two fluorescent substrates: Abz-FRK(Dnp)P-OH, which was designed for ACE studies [31], and Abz-GGFLRRV-EDDnp, homologous to the dynorphin 1-13 sequence and previously determined as substrate for Tsv endopeptidases [18]. Results are presented in Figure1.

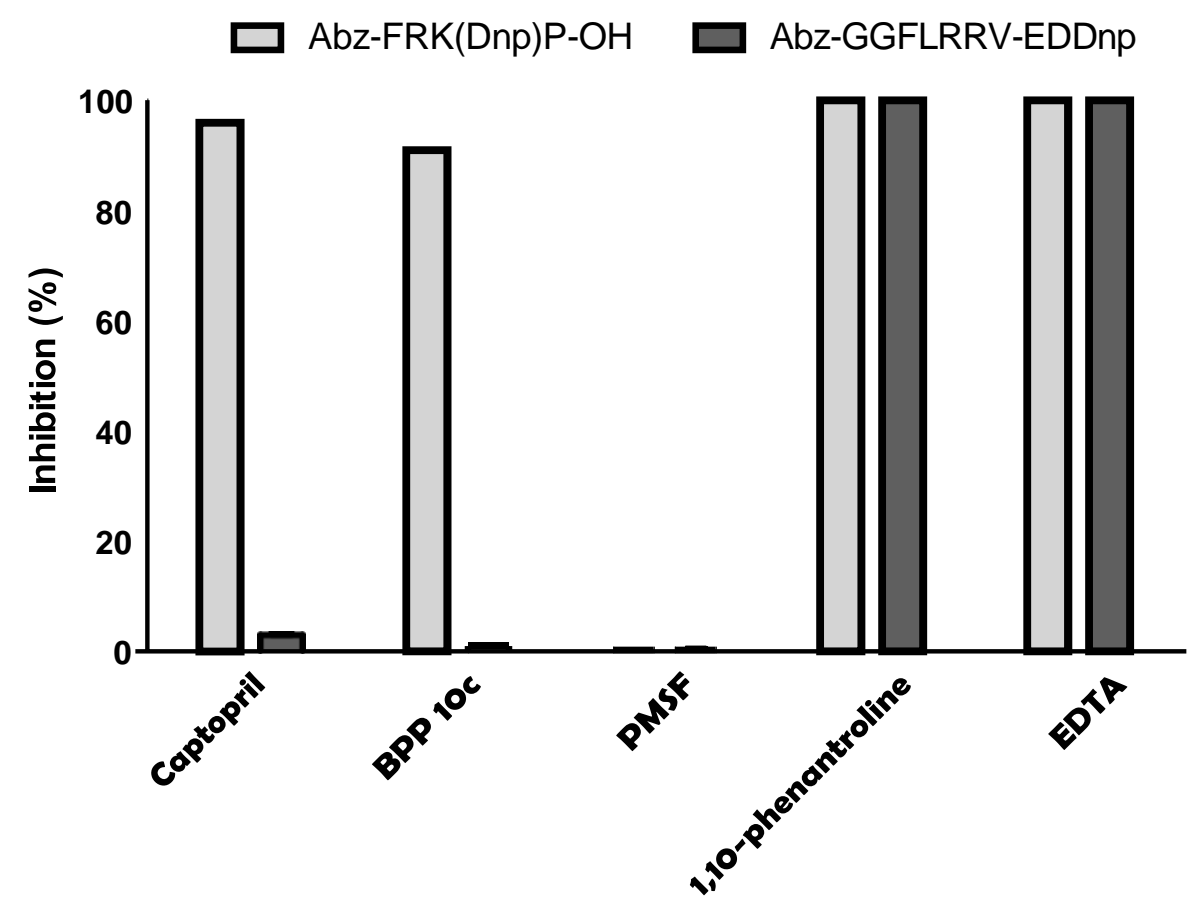

Figure 1. Fluorimetric assays for carboxy- and endopeptidases activities on Tsv using peptidase inhibitors. Captopril $(100 \mathrm{nM})$, BPP 10c $(16 \mu \mathrm{M})$, EDTA $(50 \mathrm{mM}), 1,10$-phenantroline $(2 \mathrm{mM})$, PMSF $(2 \mathrm{mM})$ were tested on the whole Tityus serrulatus venom $(1 \mu \mathrm{g})$ in a fluorometric assay with Abz-FRK(Dnp)P-OH (dark grey) and Abz-GGFLRRV-EDDnp (light grey). The reactions occurred in $100 \mathrm{mM}$ Tris, $50 \mathrm{mM} \mathrm{NaCl}, 10 \mu \mathrm{M} \mathrm{ZnCl} 2$ buffer, pH 7.0 at $37^{\circ} \mathrm{C}$. Experiments were done in duplicate. The SD of kinetic results in each case was never greater than $5 \%$ of the value obtained.

Although only metallopeptidases were detected in Tsv (due to inhibition of EDTA and 1,10phenantroline), we observed that different proteases act on each substrate. For Abz-FRK(Dnp)P-OH, the two classical ACE inhibitors, captopril (100 nM) and BPP 10c $(16 \mu \mathrm{M})$, significantly inhibited Tsv activity ( $98 \%$ and 90\%, respectively), while Abz-GGFLRRV-EDDnp hydrolysis was not affected by these inhibitors at the same concentrations. However, PMSF $(2 \mathrm{mM})$ had no effect on the activity of the venom on any fluorescent substrates tested. Thus, it seems that Abz-GGFLRRV-EDDnp is cleaved mainly by metalloendopeptidases and Abz-FRK(Dnp)P-OH by metallo dipeptidyl carboxypeptidases.

\subsection{In Vitro Serum Neutralization Assays Using Abz-FRK(Dnp)P-OH as Substrate}

We tested nine different concentrations of arachnid (AAV) and scorpion (SAV) antivenoms to determine their efficacy in neutralizing Tsv hydrolysis of Abz-FRK(Dnp)P-OH (Figure2).

SAV partially inhibited the activity even at low venom:antivenom ratios, whereas AAV started inhibiting Tsv at a higher dose, after $25 \mu \mathrm{g}$ of antivenom (1:25), but also reached higher levels of inhibition than SAV at concentrations of 1:500 $\mu \mathrm{g}$. Neither antivenom fully neutralized Tsv activity at the highest dose tested (1:1000), with inhibition reaching 94\% for SAV and 98\% for AAV. 




Figure 2. In vitro serum neutralization of Abz-FRK(Dnp)P-OH hydrolysis by Tsv using scorpion (SAV) and arachnid (AAV) commercial antivenoms. The venom was incubated for $30 \mathrm{~min}$ at room temperature with nine concentrations of antivenom (weight ratio of venom:antivenom) - 1:1; 1:2; 1:10; $1: 25 ; 1: 50 ; 1: 100 ; 1: 250 ; 1: 500$, and 1:1000 - and then the fluorescent substrate was added. The result is expressed as \% inhibition of peptidase activity in the venom (\%). The result represents the mean of two independent experiments. The SD of kinetic results in each case was never greater than $5 \%$ of the value obtained.

\subsection{Effect of Chloride Ion Concentration on Tsv andsACE}

As chloride ions are known to affect ACE activity [32], we compared Tsv and ACE hydrolysis of the Abz-FRK(Dnp)P-OH substrate in the presence of different $\mathrm{Cl}^{-}$concentrations (Figure3).

As showed in Figure3, both enzymes were already active in the absence of $\mathrm{NaCl}$, with higher proteolytic activities observed as $\mathrm{NaCl}$ concentrations increased. At $10 \mathrm{mM} \mathrm{NaCl}, T s \mathrm{v}$ and ACE activities increased by $15 \%$ and $25 \%$, respectively, and, at the highest $\mathrm{NaCl}$ concentration tested (50 mM) hydrolysis of Abz-FRK(Dnp)P-OH by Tsv increased by more than $35 \%$, and around $46 \%$ by ACE.

A) ACE



B) TsV

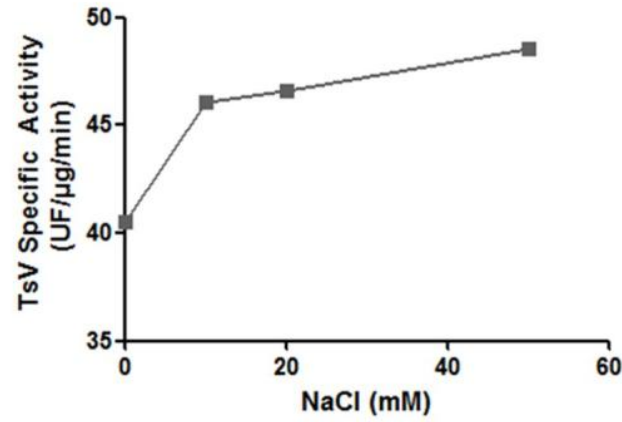

Figure 3. Effect of chloride ions concentration on (A) angiotensin-converting enzyme (ACE) and (B) Tityus serrulatus venom. For both, Abz-FRK(Dnp)P-OH hydrolysis was determined in Tris $100 \mathrm{mM}$, $\mathrm{ZnCl}_{2} 10 \mu \mathrm{M}$ buffer, with four different concentrations of $\mathrm{NaCl}: 0,10 \mathrm{mM}, 20 \mathrm{mM}$, and $50 \mathrm{mM}$. The result represents the mean of two independent experiments. The SD of kinetic results in each case was never greater than $5 \%$ of the value obtained. 


\subsection{Hydrolysis of ACE Natural Substrates by Tsv}

Angiotensin I and bradykinin were incubated with Tsv in the classical ACE working buffer, $100 \mathrm{mM}$ Tris, $50 \mathrm{mM} \mathrm{NaCl}, 10 \mu \mathrm{M} \mathrm{ZnCl}_{2}$, $\mathrm{pH}$ 7.0. After verifying, with reserve phase chromatography, that both peptides were substrates for Tsv, we manually collected the products of hydrolysis and analyzed them by mass spectrometry. Additionally, we determined the specific activity of the venom on each peptide, including hemopressin, and determined the cleavage sites (Table1).

Table 1. Hydrolysis of biologically active peptides by Tityus serrulatus venom and released fragments.

\begin{tabular}{|c|c|c|c|c|}
\hline Peptide & Fragment Sequence & Fragment Identification & MW & Venom Specific Activity $(\mu \mathrm{M} / \mu \mathrm{g} / \mathrm{min})$ \\
\hline \multirow{7}{*}{ Angiotensin I } & DRVY & $\operatorname{Ang}_{(1-4)}$ & 551.2 & \multirow{7}{*}{0.050} \\
\hline & IHPFHL & $\operatorname{Ang}_{(5-10)}$ & 762.4 & \\
\hline & HPFHL & $\operatorname{Ang}_{(6-10)}$ & 649.3 & \\
\hline & DRVYIHP & $\operatorname{Ang}_{(1-7)}$ & 898.4 & \\
\hline & DRVYIHPF & Ang II & 1045.4 & \\
\hline & RVYIHPF & Ang III & 930.5 & \\
\hline & FHL & $\operatorname{Ang}_{(8-10)}$ & 415.2 & \\
\hline \multirow{3}{*}{ Bradykinin } & RPPGF & $\mathrm{BK}_{(1-5)}$ & 572.3 & \multirow{3}{*}{0.045} \\
\hline & RPPGFSP & $\mathrm{BK}_{(1-7)}^{(1-7)}$ & 756.3 & \\
\hline & PGFSPFR & $\mathrm{BK}_{(3-9)}^{\prime}$ & 806.4 & \\
\hline \multirow{5}{*}{ Hemopressin } & PVNFKFL & $\mathrm{Hemo}_{(1-7)}$ & 863.4 & \multirow{5}{*}{0.400} \\
\hline & PVNFKF & $\operatorname{Hemo}_{(1-6)}$ & 750.4 & \\
\hline & PVNFK & $\operatorname{Hemo}_{(1-5)}$ & 603.3 & \\
\hline & KFLSH & $\operatorname{Hemo}_{(5-9)}$ & 630.35 & \\
\hline & FLSH & $\mathrm{Hemo}_{(6-9)}$ & 502.25 & \\
\hline
\end{tabular}

Assays were carried out in $100 \mathrm{mM}$ Tris buffer containing $50 \mathrm{mM} \mathrm{NaCl}, 10 \mu \mathrm{M} \mathrm{ZnCl}_{2}, \mathrm{pH} 7.0$, at $37^{\circ} \mathrm{C}$, in a final volume of $100 \mu \mathrm{L}$. The results are shown as the mean of three independent experiments. The SD of kinetic was never greater than $5 \%$ of the value obtained.

Hemopressin was the best substrate for the whole venom $(0.40 \mu \mathrm{M} / \mu \mathrm{g} / \mathrm{min})$, followed by angiotensin I $(0.05 \mu \mathrm{M} / \mu \mathrm{g} / \mathrm{min})$ and bradykinin $(0.045 \mu \mathrm{M} / \mu \mathrm{g} / \mathrm{min})$. One of the fragments collected from angiotensin I corresponded to angiotensin II, due to the removal of His ${ }^{9}-\mathrm{Leu}^{10}$. Other fragments were also formed from angiotensin I hydrolysis, such as Ang (1-4), Ang(5-10), Ang $(1-7)$, and Ang(8-10), probably due to endopeptidase activity; and Ang III and Ang (6-10), probably due to aminopeptidase activity. Bradykinin hydrolysis by the venom formed the fragments $\mathrm{BK}_{(1-7)}, \mathrm{BK}_{(1-5)}$, the expected products of ACE-like activity, and $\mathrm{BK}_{(3-7)}$. Hemopressin cleavage sites were determined previously [18], but the hydrolysis rate increased 5.6 times when the buffer containing $10 \mu \mathrm{M} \mathrm{ZnCl}_{2}$ wasused.

\subsection{Inhibition Assay on Reverse Phase Chromatography}

As new substrates and hydrolysis rates were observed for Tsv when using the ACE buffer, weevaluated inhibition by captopril, a potent and specific human ACE inhibitor, and by EDTA(Table2).

Table 2. Inhibition of Tsv activity on bioactive peptides by captopril and EDTA.

\begin{tabular}{cccc}
\hline \multirow{2}{*}{ Peptide } & \multicolumn{3}{c}{ Inhibitory Activity (\%) } \\
\cline { 2 - 4 } & EDTA & Captopril 100 nM & Captopril 1 $\mathbf{~ M}$ \\
\hline Angiotensin-I & 100 & 8.2 & 48.6 \\
Bradykinin & 100 & 36.3 & 60.0 \\
Dynorphin A & 100 & 0.0 & 1.8 \\
Hemopressin & 100 & 37.8 & 8.9 \\
\hline
\end{tabular}

Experiments were made using $100 \mathrm{mM}$ Tris, $50 \mathrm{mM} \mathrm{NaCl}, 10 \mu \mathrm{M} \mathrm{ZnCl}_{2}$ buffer, $\mathrm{pH} 7.0$ at $37^{\circ} \mathrm{C}$ with $\mathrm{Tsv}(1 \mu \mathrm{g})$, at $37^{\circ} \mathrm{C}$, using $30 \mu \mathrm{M}$ of each biologically active peptide substrate. The incubations varied according to the particularity of each substrate, as described in Section4.6. The results shown are the mean of three independent experiments. The SD of kinetic was never greater than $5 \%$ of the value obtained. 
EDTA fully inhibited the activity of Tsv on all substrates. Captopril, in either of the two concentrations tested, failed to inhibit the cleavage of dynorphin 1-13 in any concentration, which was expected, as a similar result was observed with the analog fluorescent substrate, Abz-GGFLRRV-EDDnp (Figure1) . On the other hand, captopril inhibited bradykinin and angiotensin I hydrolyses in a dose-dependent manner (Table2). Hydrolysis of hemopressin was also strongly inhibited (37.8\%) by 100 nM captopril, but less so with a higher dose $(1 \mu \mathrm{M})$ of this inhibitor. The RP-HPLC profile of hemopressin hydrolysis by Tsv (Figure4), shows that, when captopril was present (in both doses), one of the products (PVNFKFL) was not formed, indicating that the dipeptidyl carboxypeptidase activity of the whole venom was abolished. Nevertheless, the other products (PVNFK and FLSH) were not affected by this inhibitor.

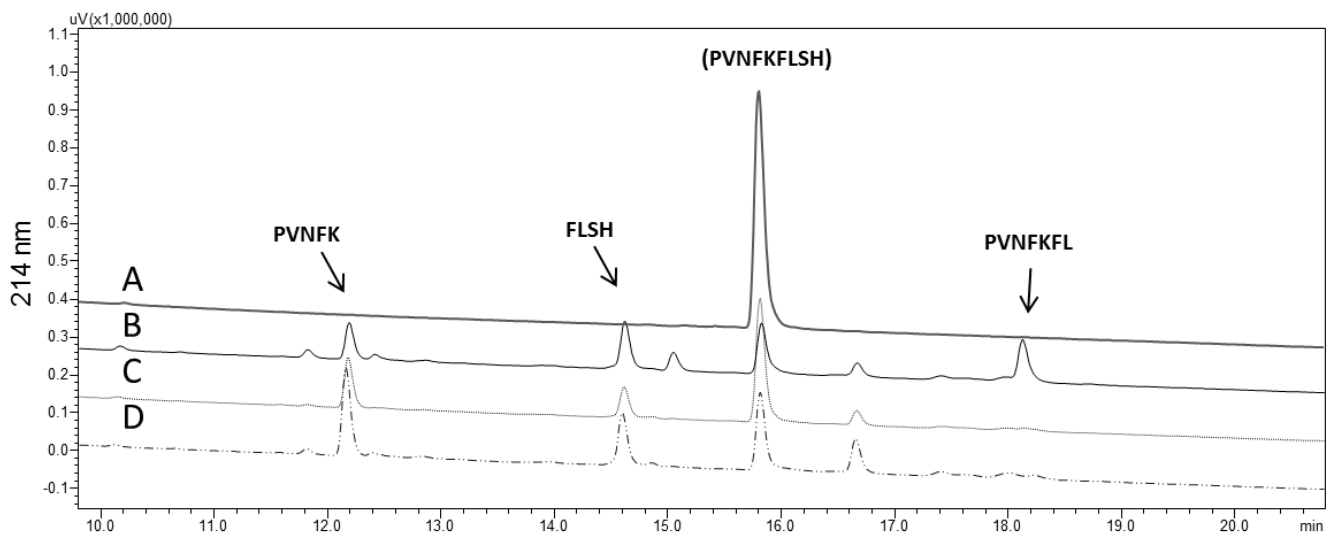

Figure 4. Hemopressin hydrolysis by Tityus serrulatus venom on RP-HPLC. (A) Hemopressin, $30 \mu \mathrm{M}$, without venom; (B) hemopressin after $2 \mathrm{~h}$ incubation with Tsv (1 $\mu \mathrm{g})$, and its fragments; (C,D) hemopressin hydrolyzed by Tsv in presence of $100 \mathrm{nM}$ and $1 \mu \mathrm{M}$ of captopril, respectively, showing that the product (PVNFKFL) is not formed. Experiments were done in duplicate.

\subsection{Purification of ACE-Like Peptidase from T. serrulatus Venom}

In order to purify the ACE-like peptidase present in Tsv, we performed three chromatographic steps to obtain a homogeneous and active enzyme. First, the whole Tsv was applied to an HPLC-DEAE column, and the ACE-like activity was identified (77 UF/ $\mu \mathrm{g} / \mathrm{min}$ ) in fraction 1 , which did not interact with the column (data not show). Then, fraction 1 was loaded onto a Diol-300 column, from which fractions were collected (Figure5, panel A) and screened by Abz-FRK(Dnp)P-OH hydrolysis. Since fraction F1-2 showed the best hydrolysis rates $(88 \mathrm{UF} / \mu \mathrm{g} / \mathrm{min})$, it was further fractioned with PA-CM ion exchange chromatography. After this last step, we observed one active fraction, presenting a single band of $70 \mathrm{kDa}$ (Figure5, panel B), with a specific activity of $220 \mathrm{UF} / \mu \mathrm{g} / \mathrm{min}$ on the FRET substrate. In the final chromatography step, the purification factor obtained was 22.9 with a yield of $1 \%$ (TableS1).

The protein content from the SDS-PAGE band was extracted and subjected to MS/MS for peptide fingerprint analysis. Using a database that combined sequences restricted to Tityus genus from UNIPROT and the transcript sequences of ACE-like peptidase from Tityus scorpion venom glands, PeaksDB was able to identify, with high confidence (FDR $\leq 1 \%$ ), two unique ACE-like peptides from Tityus serrulatus (TserSP00939) (Figure6). Additionally, the pure enzyme was able to convert angiotensin I into angiotensin II, in addition to Abz-FRK(Dnp)P-OH, with specific activity of $0.01 \mu \mathrm{M} / \mu \mathrm{g} / \mathrm{min}$ (Figure5, panel C). 



Figure 5. Purification of ACE-like enzyme from Tityus serrulatus venom. (A) Fraction 1 was fragmented in gel filtration Diol-300 column, and F1-2 was the only fraction able to cleave the FRET substrate. SDS-PAGE showed a separation of low molecular weight bands. (B) Profile of the fraction F1-2 on a cation exchange column (black line), with F1-2.7 being the fraction with the highest peptidase activity, and resulting in a single protein band in 13\% SDS-PAGE. In order to maintain the activity, after each step the buffer was immediately changed to $100 \mathrm{mM}$ Tris, $50 \mathrm{mM} \mathrm{NaCl}, 10 \mu \mathrm{M} \mathrm{ZnCl}$ buffer, pH 7.0, using a $10 \mathrm{kDa}$ molecular weight cutoff membrane. The grey line represents the $\mathrm{NaCl}$ gradient. (C) Conversion of angiotensin I into angiotensin II by the purified ACE-like enzyme. The details of the experiments are described in Section4.8. 




Figure 6. Tryptic peptides from fraction F1-2.7 that matched with the predicted ACE-like from T. serrulatus (GenBank TserSP00939) obtained from transcriptomic analysis. The peptides were found using Peaks DB with FDR $\leq 1 \%$.

\subsection{Sequence Analysis}

We aligned the amino acid sequences of ACE-like peptidases obtained from transcriptomics data analysis from Tityus serrulatus, T. obscurus and T. bahiensis with each other and with human testicular ACE (Table3).

Table 3. Identity (white) and similarity (grey) between ACE-like from the venom of Brazilian Tityus sp. scorpions and Homo sapiens testicular ACE(AAA60611.1).

\begin{tabular}{ccccc}
\hline Proteins & $\begin{array}{c}\text { TesticularACE Homo sapiens } \\
\text { (AAA60611.1) }\end{array}$ & $\begin{array}{c}\text { T. serrulatus } \\
\text { (TserSP00939) }\end{array}$ & $\begin{array}{c}\text { T. bahiensis } \\
\text { (JAG85170) }\end{array}$ & $\begin{array}{c}\text { T. obscurus } \\
\text { (Tobs01141) }\end{array}$ \\
\hline testicularACE Homo sapiens & & & & \\
(AAA60611.1) & & $39.18 \%$ & $23.12 \%$ & $39.18 \%$ \\
\hline T. serrulatus (TserSP00939) & $46.39 \%$ & & $67.21 \%$ & $90.34 \%$ \\
\hline T. bahiensis (JAG85170) & $28.16 \%$ & $67.34 \%$ & & $61.22 \%$ \\
\hline T obscurus (Tobs01141) & $46.53 \%$ & $92.51 \%$ & $62.31 \%$ & \\
\hline
\end{tabular}

The identity with human tACE varied from $23 \%$ to $39 \%$; however, the metallopeptidase motif was highly conserved throughout the species (Figure S1). The ACE-like sequences ofTityus serrulatus (TserSP00939) and Tityusobscurus (Tobs01141) had 92.51\% of similarity, while the tbahACE-like sequence shared $62.31 \%$ and $67.34 \%$ similarity with T. obscurus and T. serrulatus, respectively.

\section{Discussion}

Using enzymatic assays, protein purification, mass spectrometry analysis, and comparative studies of the transcript sequences in the venom glands ofTityus spp. scorpions, we show for the first time the presence of an ACE-like peptidase in the venom of Tityus serrulatus.

The venom cleaves physiologically important ACE substrates, such as angiotensin I, bradykinin, and hemopressin, and captopril inhibits this activity. Expected products from these hydrolyses were observed, such as hemopressin 1-7, angiotensin II, $\mathrm{BK}_{1-5}$, and $\mathrm{BK}_{1-7}$, consistent with the ACE specificity for these substrates [33,34]. However, the presence of other fragments indicates the participation of more venom proteases in the cleavage of these substrates. In addition, Abz-FRK(Dnp)P-OH, a substrate specifically designed for ACE [31], was an important tool to identify and purify the ACE-like peptidase on T. serrulatus venom, along with the successful ACE inhibition by captopril and BPP 10c [31,35].

At the end of the third chromatography step, we observed a single protein band in the silverstained gel with molecular mass around $70 \mathrm{kDa}$ that converts angiotensin I into angiotensin II. Thus, the ACE-like enzyme present in Tsv has a molecular mass similar to tACE. Besides the precursor of ACE-like peptidase being sequenced by RNA sequencing (GenBank TserSP00939) and the identification of the ACE-like peptidase from T. serrulatus through mass spectrometric analysis, the isoform sequences are also present in transcripts from the venom gland of T. bahiensis (GenBank JAG85170.1), T. stigmurus [30], and T. obscurus (GenBank Tobs01141 and GenBank Tobs00978) [36]. Thus, these sequences helped to validate the purification of this enzyme, achieving two unique peptides 
from T. serrulatus's ACE-like sequence. Moreover, the alignment indicated high homology between the ACE sequences from Brazilian Tityus species and a conserved metallopeptidase motif HEMG $\underline{H V}$ with human tACE.

The expressive number of ACE-like enzymes described in invertebrates indicates that this metallopeptidase is conserved throughout evolution [27]. Also, in accordance with our results, the ACE-like enzymes in invertebrates include only a C-domain, similar to the human testicular form of the enzyme. Despite the many studies with ACE in invertebrates, natural substrates for these enzymes are yet to be described [27], and, therefore, their physiological role still needs clarification. In general, ACE-like peptidases show broad substrate specificity, cleaving a large number of peptides in vitro [33]. The exceptions are peptides with proline residues at the penultimate position, such as BPPs [37].

Studies have shown that male fruit flies with mutations in the ACE gene are sterile [38]. Other studies suggest a possible physiological role of ACE-like peptidases in the midgut of invertebrates, but solely based on their presence in this region [39,40]. Also, the presence of ACE-like enzymes in the neuropil area of insect brains, and the ability of the enzyme to cleave insect tachykinin (Lom TK-1) in vitro, may indicate that this enzyme participates in the processing of neuropeptides [41,42]. In this scenario, we hypothesize that the ACE-like peptidase present in T. serrulatus venom contributes to the ability to capture or kill prey.

Moreover, the presence of this enzyme in the venom may be related to forming endogenous peptides in Tsv, since a proteomic study identified post-translational modifications of toxins in this venom and showed that about $80 \%$ of the venom molecules are degraded by endogenous peptidases, particularly amino and carboxypeptidases [19]. Also, a recent report from our group showed that metallocarboxypeptidases contribute to inactivate a series of human bioactive peptides [18].

Lastly, we cannot exclude the involvement of this carboxypeptidase in the envenomation. According to Safavi-Hemami and collaborators (2013), who described an angiotensin I-converting enzyme in the venom of cone snails, this enzyme may promote vasoconstriction of blood vessels at the sting site by angiotensin II, along with catecholamine [13]. In fact, animals and patients envenomed by scorpions from the Buthidae family present elevation of plasma renin-angiotensin activity and, consequently, an increase of angiotensin II [43,44]. This observation might, at least in part, be explained by the action of the venom ACE-like enzyme, as we showed here that it is capable of releasing angiotensin II, and victims of Tityus serrulatus sting present transient hypertension [45,46]. Until now, neurotoxins were considered the main cause of hypertension in stung patients, due to catecholamine release [7]. However, as Ang II can also stimulate the release of catecholamines, this may contribute synergistically to the hypertension observed in human victims [47,48].

Besides Ang II formation by the whole venom and the purified peptidase, we also observed that Tsv acts on Ang I, releasing Ang III, a hypertensive peptide with activity comparable to Ang II [49]. Differently, Ang 1-7, another product of the action of Tsv, promotes vasodilation, which would seem to be a contradictory action of the venom. However, envenomed patients commonly present persistent hypotension after the transient hypertension [7]. Heretofore, hypotension could be explained by the presence of hypotensins, which are bradykinin-potentiating peptides that do not inhibit human ACE activity [50]. Our results suggest yet another factor that can contribute to this effect. In addition, and since animal venoms aim to destabilize homeostasis in the prey, the joint action of multiple molecules in the venom (neurotoxins, proteases, among others) is important to cause the envenomation syndrome.

Furthermore, taking into account the possible involvement of ACE-like during the envenomation, especially on hypertension, the in vitro serum neutralization of $T s \mathrm{v}$ is an important assay. The antivenom sera represent the only specific therapy available and recommended by the World Health Organization (WHO) to treat incidents involving animal venoms. In case of scorpion envenomation, the administration of either scorpion (SAV) or arachnid (AAV) antivenoms is prescribed; in the most severe cases, it is recommended to use 4-6 ampoules. Our results show that SAV and AAV 
produced different levels of neutralization: while SAV caused partial inhibition at lower doses, AAV was slightly more efficient at the highest doses. The effect of the lower SAV concentration is probably due to ACE-like peptidase being present in both scorpion venoms used for theSAV immunization pool (T. serrulatus, $50 \%$ and T. bahiensis, $50 \%$ ), as is shown in Figure S1, while the venoms used to obtain arachnid antivenom include only one scorpion species (T. serrulatus, 57\%), together with two spider species (Phoneutria nigriventer and Loxosceles gaucho). The inhibition observed using high doses of both antivenoms could be a result of some sort of interaction impairment between the ACE-like and the FRET substrate due to the high number of non-specific antibodies, and that might not represent a real neutralization by the antivenom. However, the use of higher doses of antivenom may be injurious to patients, as it can cause adverse reactions known as "serum sickness" [51].

In summary, here we describe, for the first time, the purification and characterization of ACElike enzyme in Tityus serrulatus venom, as well as two fluorescent substrates specific for endoand carboxypeptidases in this venom. Also, since we observed formation of Ang II in vitro, we hypothesize that this enzyme may also contribute to the hypertension observed in the envenomation syndrome, along with other molecules. Considering that scorpion bites are a critical public health problem in Brazil, this study demonstrates the importance of characterizing new molecules related to envenomation processes as well as evaluating antivenom therapies. The high concentrations of commercially available antivenoms necessary to partially block the ACE-like activity in Tsv may be harmful to victims.

\section{Materials and Methods}

\subsection{Reagents}

Phenylmethanesulfonylfluoride (PMSF), 1,10-phenanthroline, dynorphin 1-13 (Dyn 1-13), hemopressin (hemo), angiotensin I (Ang I), bradykinin (BK), captopril, and rabbit lung somatic angiotensin I-converting enzyme (ACE) were purchased from Sigma-Aldrich (St. Louis, MO, USA). Acetonitrile and trifluoroacetic acid (TFA) were acquired from J.T. Baker. The fluorescent resonance energy transfer (FRET) substrates Abz-GGFLRRV-EDDnp and Abz-FRK(Dnp)P-OH, synthesized with automated solid-phase synthesis [52], were kindly provided by Dr. Adriana Carmona, from the Department of Biophysics of UNIFESP-EPM, São Paulo, Brazil.

\subsection{Venoms and Antivenoms}

The lyophilized venom of Tityus serrulatus (Batch No. 2146 and batch No. 744) were provided by the Venom Section of Instituto Butantan, SP, Brazil. The venoms were submitted to a $10 \mathrm{kDa}$ molecular weight cutoff (Amicon Ultra-15 Centrifugal Filter Devices) and stock solution was prepared in $50 \mathrm{mM}$ sodium phosphate and $50 \mathrm{mM} \mathrm{NaCl}, \mathrm{pH}$ 6.0. The scorpion and arachnid antivenoms (SAV and AAV, respectively) were from the Hyperimmune Plasmas Processing Section, Instituto Butantan, SP, Brazil. The SAV (batch No. 0905104/A) and the AAV (batch No. 0706121) protein concentrations were $8.43 \mathrm{~g} / \mathrm{dL}$ and $15.4 \mathrm{~g} / \mathrm{dL}$, respectively. The antivenoms from Instituto Butantan are produced through hyperimmunization of horses, with a pool of T. serrulatus $(50 \%)$ and T. bahienses (50\%) venoms for SAV, and T. serrulatus (57\%), Phoneutria nigriventer (21.5\%) and Loxosceles gaucho (21.5\%) venoms for AAV.

\subsection{Fluorescent Substrate-Specific for Carboxy-and Endopeptidases, and Peptidase Inhibitors}

The substrate-specific assay was carried out using $1 \mu \mathrm{g}$ Tityus serrulatus venom (Tsv) and the fluorescent substrates Abz-GGFLRRV-EDDnp $(5 \mu \mathrm{M})$ [18] and Abz-FRK(Dnp)P-OH (4 $\mu \mathrm{M})$, in $100 \mathrm{mM}$ Tris, $50 \mathrm{mM} \mathrm{NaCl}, 10 \mu \mathrm{M} \mathrm{ZnCl}_{2}$ buffer, $\mathrm{pH}$ 7.0. All reactions were monitored by measuring hydrolyses using a fluorimeter (Victor $3^{\mathrm{TM}}$, Perkin-Elmer, Waltham, MA, USA; $\lambda$ em $420 \mathrm{~nm}$ and $\lambda$ ex $320 \mathrm{~nm}$ ), at a stable temperature of $37^{\circ} \mathrm{C}$. The measurements of peptidase activity were made for $15 \mathrm{~min}$ continuously (one read per minute). The fluorometric assays were analyzed using Grafit 5.0 from 
Erithacus Software (version 5.0.6, 1989-2003, Erithacus Software, West Sussex, UK), and the hydrolysis rates $(\mathrm{UF} / \mathrm{min})$ were determined. All fluorometric measurements were made in duplicate, and the results are shown as the mean withSD.

For the inhibition of Tsv, we used the serine peptidase inhibitor PMSF (2 mM), the metallopeptidase inhibitors 1,10-phenantroline $(2 \mathrm{mM})$ and EDTA $(50 \mathrm{mM})$, and the peptidasespecific inhibitors captopril $(100 \mathrm{nM})$ and BPP 10c (Bradykinin Potentiating Peptide,

$<$ ENWPHPQIPP, $16 \mu \mathrm{M}$ ). Control samples included a volume of ethanol equal to that used in the PMSF and 1,10-phenantroline stock solutions. PMSF and 1,10-phenantroline were pre-incubated for $30 \mathrm{~min}$ at room temperature before the test.

\subsection{Effect of Chloride Ion Concentration on Tsv and ACE Activities}

The effects of ion chloride on Tsv were evaluated in parallel with angiotensin I-converting enzyme (ACE) on fluorometric experiments. For this, Tsv and ACE were added to 96-well plates at concentrations of $1 \mu \mathrm{g}$ and $50 \mathrm{ng}$, respectively, in $100 \mathrm{mM}$ Tris, $10 \mu \mathrm{M} \mathrm{ZnCl}_{2}, \mathrm{pH} 7.0$ buffer, at a final volume of $100 \mu \mathrm{L}$, with $4 \mu \mathrm{M}$ Abz-FRK(Dnp)P-OH. Four concentrations of $\mathrm{NaCl}$ were tested on Tsv and ACE: 0 (control), $10 \mathrm{mM}, 20 \mathrm{mM}$, and $50 \mathrm{mM}$. All the assays were performed in triplicate, and the specific venom peptidase activities were expressed as units of free fluorescence of the cleaved substrate per $\mu \mathrm{g}$ of venom per $\min (\mathrm{UF} / \mu \mathrm{g} / \mathrm{min})$.

\subsection{In Vitro Serum Neutralization Assays Using Abz-FRK(Dnp)P-OH}

The serum neutralization assay of Tsv activity upon the Abz-FRK(Dnp)P-OH substrate was performed using different doses of the antivenoms. The Tsv $(1 \mu \mathrm{g})$ was incubated at room temperature with the antivenoms for $30 \mathrm{~min}$ in the following concentrations (weight ratio of venom and antivenom, respectively): 0 (control), 1:1; 1:2; 1:10; 1:25; 1:50; 1:100; 1:250; 1:500, and 1:1000. After incubation, the FRET substrate was added, and the residual peptidase activity of the venom measured, in duplicate, as described (Section4.3).

\subsection{Cleavage of Biologically Active Peptides and Inhibition by Captopril}

Tsv $(0.5 \mu \mathrm{g})$ was incubated in $100 \mathrm{mM}$ Tris, $50 \mathrm{mM} \mathrm{NaCl}, 10 \mu \mathrm{M} \mathrm{ZnCl} 2$ buffer, $\mathrm{pH} 7.0$, at $37{ }^{\circ} \mathrm{C}$ with dynorphin 1-13 $(30 \mu \mathrm{M})$, for $70 \mathrm{~min}$; hemopressin $(30 \mu \mathrm{M})$ for $2 \mathrm{~h}$; angiotensin I $(30 \mu \mathrm{M})$ for $4 \mathrm{~h}$; and bradykinin $(30 \mu \mathrm{M})$ for $6 \mathrm{~h}$. Captopril was used at $100 \mathrm{nM}$ and $1 \mu \mathrm{M}$ final concentrations. EDTA was also used at $100 \mathrm{mM}$ final concentration. All experiments were performed in duplicate, and the results are shown as the mean with SD. Hydrolyses were analyzed by reverse-phase HPLC (Prominence, Shimadzu, Japan), with $0.1 \%$ trifluoroacetic acid (TFA) in water, as solvent A, and acetonitrile and solvent A (9:1), as solvent B. Separations were performed at a flow rate of $1 \mathrm{~mL} / \mathrm{min}$, using a Restek Ultra C-18 column $(4.6 \mathrm{~mm} \times 250 \mathrm{~mm})$ and a $20 \%-60 \%$ gradient of solvent B over $30 \mathrm{~min}$. In all cases, elution was followed by measurement of ultraviolet absorption $(214 \mathrm{~nm})$. The specific activities were expressed in $\mu \mathrm{M}$ of hydrolyzed substrate per $\mu \mathrm{g}$ of venom per minute $(\mu \mathrm{M} / \mu \mathrm{g} / \mathrm{min})$ and the inhibition of venom peptidase activity was calculated by comparing the peptide areas.

\subsection{Mass Spectrometry Analysis of Ang-I and BK Fragments Produced by Tsv}

The products of the hydrolysis of angiotensin-I and bradykinin, catalyzed byTsv, weremanually collected and subjected to mass spectrometry analysis. The reverse phase chromatography fractions were resuspended in $0.1 \%$ formic acid and analyzed by online liquid chromatography in an Easy-nLC Proxeon nanoHPLC system coupled to an LTQ-Orbitrap Velos (Thermo Fisher Scientific, Bremen, Germany) through a nanoelectrospray ion source. Separation was carried out in a 10-cm column $\left(75 \mu \mathrm{m}\right.$ i.d. $\times 350 \mu \mathrm{m}$ e.d.) packed in-house with $5-\mu \mathrm{m}$ Jupiter ${ }^{\circledR} \mathrm{C}-18$ beads (Phenomenex, Torrance, CA, USA). Peptides were eluted with a linear gradient of $5 \%-30 \%$ acetonitrile, in $0.1 \%$ formic acid, in $45 \mathrm{~min}$ at $300 \mathrm{~nL} / \mathrm{min}$. The spectrometer was operated in data-dependent mode and the 10 most intense peaks were selected for CID fragmentation after acquiring each full scan. The settings for 
the spectrometer were defined as: high-resolution full MS parameters ( $1 \mu$ scan; full MS mass range $\mathrm{m} / z$ of 200-2000 with an $R=30,000$ and a target value of $1 \times 104$ ions; max injection time $=10 \mathrm{~ms}$ ). For fragment scans the settings were: an isolation window of $2 \mathrm{Da}$, a max list size of 500 , a time window of $30 \mathrm{~s}$, a minimum signal of 5000, activation time $=10 \mathrm{~ms}$ and normalized collision energy $=35 \%$.

\subsection{Data Analysis}

The raw data files were submitted to searches against the angiotensin I and bradykinin sequences using PEAKS Studio (version 8, Bioinformatics Solution, Waterloo, ON, Canada) [53,54]. A decoy database was also searched to calculate False Discovery Rate (FDR) using the decoy-fusion method [53,54]. The search parameters were: no enzyme specificity; precursor mass tolerance set to $\pm 10 \mathrm{ppm}$ and a fragment ion mass tolerance of $\pm 0.5 \mathrm{Da}$; oxidized methionine $(\mathrm{M}+15.994915 \mathrm{Da})$ was set as variable modification. The identified peptides were then sorted by their Average of Local Confidence (ALC) to select the best spectra to annotate, and were filtered by FDR $\leq 1 \%$.

\subsection{Purification of ACE-Like Peptidase from Tityus serrulatus Venom}

All purification steps were followed by buffer exchange to $100 \mathrm{mM}$ Tris, $50 \mathrm{mM} \mathrm{NaCl}, 10 \mu \mathrm{M}$ $\mathrm{ZnCl}_{2} \mathrm{pH} 7.0$, using a $10 \mathrm{kDa}$ molecular weight cut off (Amicon Ultra-15 Centrifugal Filter Devices), taking into account that ACE activity is sensitive to chloride concentrations [32]. Moreover, the protein content of all samples was quantified with the commercial kit Quick Start ${ }^{\mathrm{TM}}$ Bradford Protein Assay (Bio Rad, Hercules, CA, USA). In order to screen for ACE-like activity, each collected fraction was tested with a fluorometric assay ( $5 \%$ of final volume) using the fluorescent substrate Abz-FRK(Dnp)P-OH $(4 \mu \mathrm{M})$, as described in Section4.3.

The lyophilized Tityus serrulatus venom was dissolved in $5 \mathrm{~mL}$ of $20 \mathrm{mM}$ Tris, $20 \mathrm{mM} \mathrm{NaCl}$, pH 8.2 buffer (final concentration $10 \mathrm{mg} / \mathrm{mL}$ ). Tsv was first submitted to anion exchange chromatography in an HPLC system (Shimadzu Co., Kyoto, Japan) using a Shim-Pack PA-DEAE column (20 mm $\times 100 \mathrm{~mm}$ ) at $5 \mathrm{~mL} / \mathrm{min}$ flow. The gradient used was $0 \%-40 \%$ B for $40 \mathrm{~min}$ (buffer A containing $20 \mathrm{mM}$ Tris, $20 \mathrm{mM} \mathrm{NaCl}, \mathrm{pH} 8.2$ and buffer B composed of buffer A containing $500 \mathrm{mM} \mathrm{NaCl}, \mathrm{pH}$ 8.2). Next, fraction 1 was applied to a Shim-pack Diol-300 $(7.9 \mathrm{~mm} \times 50 \mathrm{~cm})$ gel filtration column coupled to an HPLC system (Shimadzu Co., Kyoto, Japan) and was eluted with $200 \mathrm{mM}$ sodium sulfate, $10 \mathrm{mM}$ sodium phosphate, $\mathrm{pH} 7.0$ buffer at $0.5 \mathrm{~mL} / \mathrm{min}$ flow rate. Then, $\mathrm{F} 1-2$, which is the active fraction upon the FRET substrate, was injected into a cation exchange Shim-Pack PA-CM column $(20 \mathrm{~mm} \times 100 \mathrm{~mm})$ in an HPLC system (Shimadzu Co., Kyoto, Japan) at a flow rate of $5 \mathrm{~mL} / \mathrm{min}$. The gradient used was $0 \%-40 \%$ B in $40 \mathrm{~min}$, with buffer A containing $20 \mathrm{mM}$ Tris, $20 \mathrm{mM} \mathrm{NaCl}, \mathrm{pH} 7.0$ and buffer B the same as buffer A but with $500 \mathrm{mM} \mathrm{NaCl}, \mathrm{pH}$ 7.0. For all chromatographic steps, UV detection was at $280 \mathrm{~nm}$. Lastly, the homogeneous ACE-like peptidase (100 ng) was incubated with angiotensin I $(30 \mu \mathrm{M})$ overnight, in $100 \mathrm{mM}$ Tris, $50 \mathrm{mM} \mathrm{NaCl}, 10 \mu \mathrm{M} \mathrm{ZnCl}_{2}$ buffer, $\mathrm{pH} 7.0$ and the hydrolysis was verified by HPLC, as described in Section4.6.

\subsection{Purified Protein Characterization}

\subsubsection{SDS-PAGE - In-Gel Digestion and MassSpectrometry}

The active fractions of each purification step were analyzed by $13 \%$ polyacrylamide gel electrophoresis (SDS-PAGE), as previously described [55]. Samples were solubilized in non-reducing sample buffers, and protein profiles were visualized by silver stain.

The 70-kDa protein band corresponding to ACE-like peptidase, obtained after the last purification step, was subjected to an in-gel digestion with trypsin (Sigma-Aldrich, St. Louis, MO, USA) [56]. The mixture was then desalted, concentrated, and resuspended in $0.1 \%$ formic acid. Mass spectrometric analysis was performed by online liquid chromatography in an Easy-nLC Proxeon nanoHPLC system coupled with an LTQ-Orbitrap Velos (Thermo Fisher Scientific, Bremen, Germany) through a nanoelectrospray ion source. Raw data files were analyzed on PEAKS Studio (version 8.0, Bioinformatics Solution, Waterloo, ON, Canada) $[53,54]$ against the library constructed with sequences 
deposited on UNIPROT with restriction to Tityus genus with addition of the ACE-like peptidase transcripts sequences from genus Tityus [17,30] (GenBank JAG85170.1, Tobs01141, TserSP00939), with a total of 383 sequences. A decoy database was also searched to calculate the false discovery rate (FDR) using the decoy-fusion method [53,54]. The search parameters were: trypsin cleavage specificity (max 1 missed cleavages); precursor mass tolerance set to $0.5 \mathrm{Da}$; and a fragment ion mass tolerance of 0.1 Da. Regarding Post Translational Modifications (PTM), we set carbamidomethylation as fixed modification and oxidized methionine, deamidation of asparagine and glutamine (NQ), and acetylation of $\mathrm{N}$-term as the variable modifications. The peptide sequences that resulted from MS/MS were analyzed in Peaks DB and the matched peptides were filtered by FDR $\leq 1 \%$, and protein confidence score $-10 \lg \mathrm{P} \geq 62$.

\subsubsection{Bioinformatic Analysis}

The deduced sequences of ACE-like peptidase transcripts from the gland of T. serrulatus (GenBank TserSP00939), T. bahiensis (JAG85170.1) [17], and T. obscurus (GenBank Tobs01141) were aligned with human testicular ACE sequence (SwissProt) using MEGA 6 software (Arizona State University, Phoenix, AZ, USA, 2014). Identities and similarities were calculated using the SIAS server, aligned by "Length of Multiple Sequence Alignment" using the BLOSUM62 matrix.

Supplementary Materials: The following are available online atwww.mdpi.com/2072-6651/8/12/348/s1, Table S1: Summary of the purification protocol of Angiotensin-converting enzyme-like from Tityus serrulatus venom; Figure S1: Sequence alignment of testicular ACE from Homo sapiens (AAA60611.1) with venom ACE-like from the scorpions Tityus serrulatus (TserSP00939), T. bahiensis (JAG85170), and Tityus obscurus (Tobs01141). The metallopeptidase motif HEXXH is marked in black, peptides found by mass spectrometry are underlined, and conserved regions are highlighted in gray.

Acknowledgments: This study was supported by the Fundação de Amparo a Pesquisa do Estado de São Paulo [Project 2015/15364-3 and Project 2013/15343-0] and INCTTOX-CNPq. We would like to express our sincere gratitude to Ismael Feitosa Lima for assistance with mass spectrometry.

Author Contributions: D.C.-C. planned and performed experiments, analyzed data, and wrote the paper; A.K.K. performed and planned experiments, analyzed data, and wrote the paper; B.D. planned experiments, analyzed data, and wrote the paper; L.K.I. contributed reagents and analysis tools; Ú.C.d.O. planned and performed experiments, and analyzed data; I.d.L.M.J.d.A. planned experiments and contributed reagents; R.T.K. planned and performed experiments, analyzed data, and wrote the paper; F.V.P. planned experiments, analyzed data, contributed reagents, and wrote the paper.

Conflicts of Interest: The authors declare no conflict of interest.

\section{References}

1. Lourenço, W.; Cuellar, O. Scorpions, scorpionism, life history strategies and parthenogenesis. J. Venom. Anim. Toxins 1995, 1, 51-62. [CrossRef]

2. Pimenta, A.M.; De Marco Almeida, F.; de Lima, M.E.; Martin-Eauclaire, M.F.; Bougis, P.E. Individual variability in Tityus serrulatus (scorpiones, buthidae) venom elicited by matrix-assisted laser desorption/ ionization time-of-flight mass spectrometry. Rapid Commun. Mass Spectrom. 2003, 17, 413-418. [CrossRef] [PubMed]

3. Cupo, P.; Jurca, M.; Azeedo-Marques, M.M.; Oliveira, J.S.; Hering, S.E. Severe scorpion envenomation in Brazil. Clinical, laboratory and anatomopathological aspects. Rev. Inst. Med. Trop. Sao Paulo 1994, 36, 67-76. [CrossRef] [PubMed]

4. Henriques, M.C.; Gazzinelli, G.; Diniz, C.R.;Gomez, M.V.Effect of the venom of the scorpion Tityus serrulatus on adrenal gland catecholamines. Toxicon 1968, 5, 175-179. [CrossRef]

5. Vasconcelos, F.; Lanchote, V.L.; Bendhack, L.M.; Giglio, J.R.; Sampaio, S.V.; Arantes, E.C. Effects of voltage-gated $\mathrm{Na}^{+}$channel toxins from Tityus serrulatus venom on rat arterial blood pressure and plasma catecholamines. Comp. Biochem. Physiol. C Toxicol. Pharmacol. 2005, 141, 85-92. [CrossRef] [PubMed]

6. Fletcher, P.L.;Fletcher, M.D.; Weninger, K.; Anderson, T.E.;Martin, B.M. Vesicle-associated membrane protein (VAMP) cleavage by a new metalloprotease from the Brazilian scorpionTityus serrulatus. J. Biol. Chem. 2010, 285, 7405-7416. [CrossRef][PubMed] 
7. Cologna, C.T.; Marcussi, S.; Giglio, J.R.; Soares, A.M.; Arantes, E.C. Tityus serrulatus scorpion venom and toxins: An overview. Protein Pept. Lett. 2009, 16, 920-932. [CrossRef] [PubMed]

8. Alvarenga, É.R.; Mendes, T.M.; Magalhaes, B.F.; Siqueira, F.F.; Dantas, A.E.; Barroca, T.M.; Horta, C.C.; Kalapothakis, E. Transcriptome analysis of the Tityus serrulatus scorpion venom gland. Open J. Genet. 2012, 2. [CrossRef]

9. Horta, C.C.; de Freitas Magalhães, B.; Oliveira-Mendes, B.B.; do Carmo, A.O.; Duarte, C.G.; Felicori, L.F.; Machado-de-Ávila, R.A.; Chávez-Olórtegui, C.; Kalapothakis, E. Molecular, immunological, and biological characterization of Tityus serrulatus venom hyaluronidase: New insights into its role in envenomation. PLoS Negl. Trop. Dis. 2014, 8. [CrossRef] [PubMed]

10. Serrano, S.M. The long road of research on snake venom serine proteinases. Toxicon 2013, 62, 19-26. [CrossRef] [PubMed]

11.Markland, F.S.; Swenson, S. Snake venom metalloproteinases. Toxicon 2013, 62, 3-18. [CrossRef] [PubMed]

12. Weston, A.J.; Chung, R.; Dunlap, W.C.; Morandini, A.C.; Marques, A.C.; Moura-da-Silva, A.M.; Ward, M.; Padilla, G.; da Silva, L.F.; Andreakis, N.; et al. Proteomic characterisation of toxins isolated from nematocysts of the South Atlantic jellyfish Olindias sambaquiensis. Toxicon 2013, 71, 11-17. [CrossRef] [PubMed]

13. Safavi-Hemami, H.; Möller, C.; Marí, F.; Purcell, A.W. High molecular weight components of the injected venom of fish-hunting cone snails target the vascular system. J. Proteom. 2013, 91, 97-105. [CrossRef] [PubMed]

14. Dani, M.P.; Richards, E.H.; Isaac, R.E.; Edwards, J.P. Antibacterial and proteolytic activity in venom from the endoparasitic wasp Pimpla hypochondriaca (hymenoptera: Ichneumonidae). J. Insect Physiol. 2003, 49, 945-954. [CrossRef]

15. DeF Fernandes-Pedrosa, M.; de L. M. Junqueira-de-Azevedo, I.; Gonçalves-de-Andrade, R.M.; Kobashi, L.S.; Almeida, D.D.; Ho, P.L.; Tambourgi, D.V. Transcriptome analysis of Loxosceles laeta (araneae, sicariidae) spider venomous gland using expressed sequence tags. BMC Genom. 2008, 9. [CrossRef]

16. Venancio, E.J.; Portaro, F.C.; Kuniyoshi, A.K.; Carvalho, D.C.; Pidde-Queiroz, G.; Tambourgi, D.V. Enzymatic properties of venoms from Brazilian scorpions of Tityus genus and the neutralisation potential of therapeutical antivenoms. Toxicon 2013, 69, 180-190. [CrossRef] [PubMed]

17. Oliveira, U.C.; Candido, D.M.; Dorce, V.A.; De L. M. Junqueira-de-Azevedo, I. The transcriptome recipe for the venom cocktail of Tityus bahiensis scorpion. Toxicon 2015, 95, 52-61. [CrossRef] [PubMed]

18. Cajado Carvalho, D.; Kuniyoshi, A.K.; Kodama, R.T.; Oliveira, A.K.; Serrano, S.M.; Tambourgi, D.V.; Portaro, F.V. Neuropeptide Y family-degrading metallopeptidases in the Tityus serrulatus venom partially blocked by commercial antivenoms. Toxicol. Sci. 2014, 142, 418-426. [CrossRef] [PubMed]

19. Verano-Braga, T.; Dutra, A.A.; León, I.R.; Melo-Braga, M.N.; Roepstorff, P.; Pimenta, A.M.; Kjeldsen, F. Moving pieces in a venomic puzzle: Unveiling post-translationally modified toxins from Tityus serrulatus. J. Proteome Res. 2013, 12, 3460-3470. [CrossRef] [PubMed]

20. Ortiz, E.; Rendón-Anaya, M.; Rego, S.C.; Schwartz, E.F.; Possani, L.D. Antarease-like Zn-metalloproteases are ubiquitous in the venom of different scorpion genera. Biochim. Biophys. Acta 2014, 1840, 1738-1746. [CrossRef] [PubMed]

21. Fletcher, M.D.; Possani, L.D.; Fletcher, P.L. Morphological studies by light and electron microscopy of pancreatic acinar cells under the effect of Tityus serrulatus venom. Cell Tissue Res. 1994, 278, 255-264. [CrossRef] [PubMed]

22. Acharya, K.R.; Sturrock, E.D.; Riordan, J.F.; Ehlers, M.R. ACE revisited: A new target for structure-based drug design. Nat. Rev. Drug Discov. 2003, 2, 891-902. [CrossRef] [PubMed]

23. Hagaman, J.R.; Moyer, J.S.; Bachman, E.S.; Sibony, M.; Magyar, P.L.; Welch, J.E.; Smithies, O.; Krege, J.H.; O’Brien, D.A. Angiotensin-converting enzyme and male fertility. Proc. Natl. Acad. Sci. USA 1998, 95, 2552 2557. [CrossRef] [PubMed]

24. Coates, D. The angiotensin converting enzyme (ACE). Int. J. Biochem. Cell Biol. 2003, 35, 769-773. [CrossRef]

25. Fourati Ben Mustapha, S.; Coulet, F.; Eyries, M.; De Larouziere, V.; Ravel, C.; Berthaut, I.; Antoine, J.M.; Soubrier, F.; Mandelbaum, J. In vitro fertilization failure of normozoospermic men: Search for a lack of testicular isozyme of angiotensin-converting enzyme. Basic Clin. Androl. 2013, 23. [CrossRef] [PubMed]

26. Pan, P.P.; Zhan, Q.T.; Le, F.; Zheng, Y.M.; Jin, F. Angiotensin-converting enzymes play a dominant role in fertility. Int. J. Mol. Sci. 2013, 14, 21071-21086. [CrossRef] [PubMed] 
27. Macours, N.; Hens, K. Zinc-metalloproteases in insects: ACE and ECE. Insect Biochem. Mol. Biol. 2004, 34, 501-510. [CrossRef] [PubMed]

28. Modica, M.V.; Lombardo, F.; Franchini, P.; Oliverio, M. The venomous cocktail of the vampire snail Colubraria reticulata (mollusca, gastropoda). BMC Genom. 2015, 16. [CrossRef] [PubMed]

29. Morgenstern, D.; Rohde, B.H.; King, G.F.; Tal, T.;Sher, D.; Zlotkin, E. The tale of a resting gland: Transcriptome of a replete venom gland from the scorpion Hottentotta judaicus. Toxicon 2011, 57, 695-703. [CrossRef] [PubMed]

30. Almeida, D.D.; Scortecci, K.C.; Kobashi, L.S.; Agnez-Lima, L.F.; Medeiros, S.R.; Silva-Junior, A.A.; De L. M. Junqueira-de-Azevedo, I.; de F Fernandes-Pedrosa, M. Profiling the resting venom gland of the scorpion Tityus stigmurus through a transcriptomic survey. BMC Genom. 2012, 13. [CrossRef] [PubMed]

31. Araujo, M.C.; Melo, R.L.; Cesari, M.H.; Juliano, M.A.; Juliano, L.; Carmona, A.K. Peptidase specificity characterization of $C$ - and $N$-terminal catalytic sites of angiotensin I-converting enzyme. Biochemistry 2000, 39, 8519-8525. [CrossRef] [PubMed]

32. Yates, C.J.; Masuyer, G.;Schwager,S.L.; Akif, M.;Sturrock, E.D.; Acharya, K.R. Molecular and thermodynamic mechanisms of the chloride-dependent human angiotensin-I-converting enzyme (ACE).J. Biol. Chem. 2014, 289, 1798-1814. [CrossRef] [PubMed]

33. Bernstein, K.E.; Ong, F.S.; Blackwell, W.L.; Shah, K.H.; Giani, J.F.; Gonzalez-Villalobos, R.A.; Shen, X.Z.; Fuchs, S.; Touyz, R.M. A modern understanding of the traditional and nontraditional biological functions of angiotensin-converting enzyme. Pharmacol. Rev. 2013, 65, 1-46. [CrossRef] [PubMed]

34. Blais, P.-A.; Côté, J.; Morin, J.; Larouche, A.; Gendron, G.; Fortier, A.; Regoli, D.; Neugebauer, W.; Gobeil, F. Hypotensive effects of hemopressin and bradykinin in rabbits, rats and mice: A comparative study. Peptides 2005, 26, 1317-1322. [CrossRef] [PubMed]

35. Camargo, A.C.; Fernandes, B.L.; Cruz, L.; Ferro, E.S. Bioactive peptides produced by limited proteolysis. In Colloquium Series on Neuropeptides; Morgan \& Claypool Life Sciences: San Rafael, CA, USA, 2012; pp. 1-92.

36. Oliveira, U.C.; Nishiyama, M.Y.,Jr.; Santos, M.B.V.;Silva, A.P.S.; Chalkidis, H.M.; Imberg, A.S.; Candido, D.M.; Yamanouye, N.; Dorce, V.A.C.; de Azevedo L. M. Junqueira, I. Proteomics endorsed transcriptomics profile of the venom gland from Tityus scorpions. Unpublished work; manuscript in preparation.

37. Cheung, H.S.; Wang, F.L.; Ondetti, M.A.; Sabo, E.F.; Cushman, D.W. Binding of peptide substrates and inhibitors of angiotensin-converting enzyme. Importance of the COOH-terminal dipeptide sequence. J. Biol. Chem. 1980, 255, 401-407. [PubMed]

38. Tatei, K.; Cai, H.; Ip, Y.T.; Levine, M. Race: A drosophila homologue of the angiotensin converting enzyme. Mech. Dev. 1995, 51, 157-168. [CrossRef]

39. Isaac, R.E. Neuropeptide-degrading endopeptidase activity of locust (Schistocerca gregaria) synaptic membranes. Biochem. J. 1988, 255, 843-847. [CrossRef] [PubMed]

40. Wijffels, G.; Fitzgerald, C.; Gough, J.; Riding, G.; Elvin, C.; Kemp, D.; Willadsen, P. Cloning and characterisation of angiotensin-converting enzyme from the dipteran species, haematobia irritans exigua, and its expression in the maturing male reproductive system. Eur. J. Biochem. 1996, 237, 414-423. [CrossRef] [PubMed]

41. Schoofs, L.; Veelaert, D.; De Loof, A.; Huybrechts, R.; Isaac, E. Immunocytochemical distribution of angiotensin I-converting enzyme-like immunoreactivity in the brain and testis of insects. Brain Res. 1998, 785, 215-227. [CrossRef]

42. Isaac, R.E.; Bland, N.D.;Shirras, A.D. Neuropeptidases and the metabolic inactivation of insectneuropeptides. Gen. Comp. Endocrinol. 2009, 162, 8-17. [CrossRef] [PubMed]

43. Murthy, K.R.; Vakil, A.E. Elevation of plasma angiotensin levels in dogs by indian red scorpion (Buthus tamulus) venom \& its reversal by administration of insulin+tolazoline. Indian J. Med. Res. 1988, 88, 376-379. [PubMed]

44. Bawaskar, H.S.; Bawaskar, P.H. Scorpion sting: Update. J. Assoc. Physicians India 2012, 60, 46-55. [CrossRef]

45. Sofer, S.; Shahak, E.; Gueron, M. Scorpion envenomation and antivenom therapy. J. Pediatr. 1994, 124, 973 978. [CrossRef]

46. Bucaretchi, F.; Fernandes, L.C.; Fernandes, C.B.; Branco, M.M.; Prado, C.C.; Vieira, R.J.; De Capitani, E.M.; Hyslop, S. Clinical consequences of Tityus bahiensis and Tityus serrulatus scorpion stings in the region of campinas, southeastern Brazil. Toxicon 2014, 89, 17-25. [CrossRef] [PubMed] 
47. Peach, M.J.; Cline, W.H.; Watts, D.T. Release of adrenal catecholamines by angiotensin. Ii. Circ Res 1966, 19, 571-575. [CrossRef] [PubMed]

48. Diz, D.I. Another chapter in the understanding of angiotensin-catecholamine interactions relevant to blood pressure control. Exp. Physiol. 2014, 99, 1595-1596. [CrossRef] [PubMed]

49. Reaux, A.; Fournie-Zaluski, M.C.; Llorens-Cortes, C. Angiotensin III: A central regulator of vasopressin release and blood pressure. Trends Endocrinol. Metab. 2001, 12, 157-162. [CrossRef]

50. Verano-Braga, T.; Figueiredo-Rezende, F.; Melo, M.N.; Lautner, R.Q.; Gomes, E.R.; Mata-Machado, L.T.; Murari, A.; Rocha-Resende, C.; Elena de Lima, M.; Guatimosim, S.; et al. Structure-function studies of Tityus serrulatus hypotensin-I (TsHpt-i): A new agonist of b(2) kinin receptor. Toxicon 2010, 56, 1162-1171. [CrossRef] [PubMed]

51. Bahloul, M.; Chabchoub, I.; Chaari, A.; Chtara, K.; Kallel, H.; Dammak, H.; Ksibi, H.; Chelly, H.; Rekik, N.; Ben Hamida, C.; et al. Scorpion envenomation among children: Clinical manifestations and outcome (analysis of 685 cases). Am. J. Trop. Med. Hyg. 2010, 83, 1084-1092. [CrossRef] [PubMed]

52. Hirata, I.Y.; Cezari, M.H.S.; Nakaie, C.R.; Boschcov, P.; Ito, A.S.; Juliano, M.; Juliano, L. Internally quenched fluorogenic protease substrates: Solid-phase synthesis and fluorescence spectroscopy of peptides containing ortho-aminobenzoyl/dinitrophenyl groups as donor-acceptor pairs. Lett. Pept. Sci. 1994, 1, 299-308. [CrossRef]

53. Ma, B.; Zhang, K.; Hendrie, C.; Liang, C.; Li, M.; Doherty-Kirby, A.; Lajoie, G. Peaks: Powerful software for peptide de novo sequencing by tandem mass spectrometry. Rapid Commun. Mass Spectrom. 2003, 17, 2337-2342. [CrossRef] [PubMed]

54. Zhang, J.; Xin, L.; Shan, B.; Chen, W.; Xie, M.; Yuen, D.; Zhang, W.; Zhang, Z.; Lajoie, G.A.; Ma, B. PEAKS DB: De novo sequencing assisted database search for sensitive and accurate peptide identification. Mol. Cell. Proteom. 2012, 11, M111.010587. [CrossRef] [PubMed]

55. Laemmli, U.K. Cleavage of structural proteins during the assembly of the head of bacteriophage T4.Nature 1970, 227, 680-685. [CrossRef] [PubMed]

56. Shevchenko, A.; Tomas, H.; Havlis, J.; Olsen, J.V.; Mann, M. In-gel digestion for mass spectrometric characterization of proteins and proteomes. Nat. Protoc. 2006, 1, 2856-2860. [CrossRef] [PubMed]

(C) 2016 by the authors; licensee MDPI, Basel, Switzerland. This article is an open access article distributed under the terms and conditions of the Creative Commons Attribution (CC-BY) license (http://creativecommons.org/licenses/by/4.0/). 
Purification and characterization of Angiotensin-Converting Enzyme-like peptidase from Tityus serrulatus venom

Daniela Cajado-Carvalho, Roberto Tadashi Kodama, Alexandre Kazuo Kuniyoshi, Bruno Duzzi, Úrsula Castro de Oliveira, Inácio de Loiola Meirelles Junqueira de Azevedo, Fernanda Vieira Portaro*.

Immunochemistry Laboratory, Butantan Institute, São Paulo, SP, Brazil;

Special Laboratory for Applied Toxinology, Butantan Institute/ Center of Toxins, ImmuneResponse and Cell Signaling (CeTICS), São Paulo, SP, Brazil;

*Correspondence address for Fernanda Portaro: Immunochemistry Laboratory, Butantan Institute, Av. Prof. Vital Brasil, 1500, CEP 05503-900, São Paulo, SP, Brazil. Tel 55-11-2627-9716 E-mail: fernanda.portaro@butantan.gov.br

\section{Supplementary Information}

Supplementary material 1. Summary of the purification protocol of Angiotensin-converting enzyme-like from Tityus serrulatus venom

\begin{tabular}{|c|c|c|c|c|c|c|c|c|}
\hline Steps & Fraction & $\begin{array}{c}\text { Volume } \\
(\boldsymbol{\mu} \mathbf{L})\end{array}$ & $\begin{array}{c}\text { Protein } \\
(\mu \mathrm{g})\end{array}$ & $\begin{array}{c}\text { Activity } \\
\text { (UF/min) }\end{array}$ & $\begin{array}{c}\text { Total } \\
\text { activity } \\
\text { (units* } \\
\mu \mathrm{L} \text { ) }\end{array}$ & 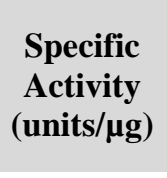 & $\begin{array}{l}\text { Purification } \\
\text { factor }\end{array}$ & $\begin{array}{c}\text { Yield } \\
(\%)\end{array}$ \\
\hline Crude venom & $\begin{array}{l}\text { Whole } \\
\text { venom }\end{array}$ & 2000 & 25000 & 1801 & 3602000 & 144,1 & 1,00 & 1 \\
\hline DEAE & F1 & 500 & 778 & 1800 & 900000 & 1156,8 & 8,03 & 100 \\
\hline Gel Filtration & F1-2 & 500 & 61 & 161 & 80500 & 1319,7 & 9,16 & 1119 \\
\hline PA-CM & F1-2.7 & 1500 & 10 & 22 & 33000 & 3300,0 & 22,90 & 8186 \\
\hline
\end{tabular}


Supplementary material 2. Sequence alignment of testicular ACE from Homo sapiens

(AAA60611.1) with venom ACEs from the scorpions T. bahiensis (JAG85170), Tityus obscurus

(Tobs01141) and Tityus serrulatus (Tser01365). The metallopeptidase motif HEXXH is marked

in black, peptides found by mass spectometry are underlined and conserved regions

highlighted in grey

Homo sapiens (AAA60611.1) Tityus bahiensis (JAG85170) Tityus obscurus (Tobs01141) Tityus serrulatus (Tser01365)

Homo sapiens (AAA60611.1) Tityus bahiensis (JAG85170) Tityus obscurus (Tobs01141) Tityus serrulatus (Tser01365)

Homo sapiens (AAA60611.1) Tityus bahiensis (JAG85170) Tityus obscurus (Tobs01141) Tityus serrulatus (Tser01365)

Homo sapiens (AAA60611.1) Tityus bahiensis (JAG85170) Tityus obscurus (Tobs01141) Tityus serrulatus (Tser01365) Homo sapiens (AAA60611.1) Tityus bahiensis (JAG85170) Tity us obscurus (Tobs01141) Tityus serrulatus (Tser01365)

Homo sapiens (AAA60611.1) Tityus bahiensis (JAG85170) Tityus obscurus (Tobs01141)

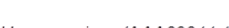
Tity us bahiensis (JAG85170)
Tityus obscurus (Tobs01141) Tityus serrulatus (Tser01365)

Homo sapiens (AAA60611.1) Tity us bahiensis (JAG85170) Tityus obscurus (Tobsor141)

Homo sapiens (AAA60611.1) Tityus bahiensis (JAG85170) Tityus obscurus (Tobs01141) Tityus serrulatus (Tser01365)

Homo sapiens (AAA60611.1) Tityus bahiensis (JAG85170) Tity us obscurus (Tobs01141)

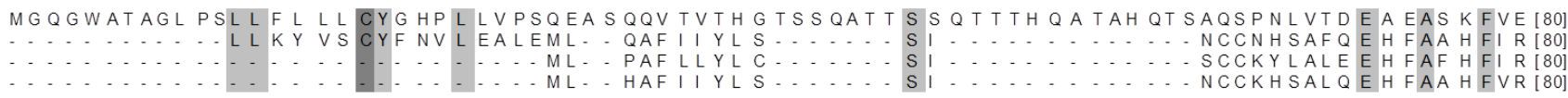

EYDRT SQVVWNEYAE A NWNYN TN I TTETSKI LLQKNMQI A NHTLKYGT QAR KFDVNQLQNTTIKRIIKKVQDLERA A LPA [160] HANEV NEKQC NLFQ T A SWNYDTDI TI LNKNKMI QQ QMI A S NVSKKI WG VL TKFP WK KFS DPQLRRQFYQLSFL GDSALSD [160) HANEVNEKQCNLFQTA Y WNYDTNI TI FNKNKMIQQQMI AS NVS KKI WG L T KFP WK KFSDPQLRRQFYQLSFL GDSALSD [160] QELEEYNKI L LDMET T YS VAT VCHP. - N GS CLQLEPDLT NVMATSR KYEDLLWAWEGWRDKAGRAILQFYPKYVELI NQ [240] DKLRKKSSLE ADMT KI Y S T TT I C D FT NKN KCNLSL DPDL S NI L ANSN N Y Y ELLYVWKEWRNKVGRKI KPLY WE FVHL KNE [24O DKIRKKTSLE ADMT NI Y S T T T C D FKNKKKCNLSLEPDL S SI MANSN D Y Y ELLHVWKEWRNKVGRKI RPLY WEFVDL KNE [24 DKLRKKSSLEADMTKI YSTTTI C DFT NKN KCNLSLDPDLSNI LANSNNYYELLYVWKEWRNKVGRKI KPLYWE FVHLKNE [240 AARLN GYVDA GDSWRS MYETPSLEQDLERLFQELQPLYLN LHAYVRRALHRHYGAQHINLEGPI PAHLLGN MWAQT WSNI [320] AARLN GFKNA GEFQRE KYESPTL I QDLEDLWQQIR PLYQQLHAYVRRR I EKYGNDKISAHGPIPAHLLGN MWSQE WQNI [320]

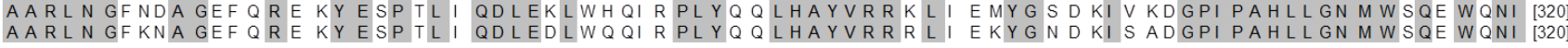
YDLVVPFPSA PSMDT T EA MLKQGWTPRRMFKEADDFFTSLGLLPVPPEF WNKSMLEKPT DGREVVCHASAWDFYNGK DFR [400 I N I TI PYRNK PSLDVTPQMKA KG MKPVQI AKLAEQFFVSLGLKPMTKEF WSNSLLEKPKD.RKVVCHASAWDL CNKR DFR [400 $\underline{\underline{G}} \underline{\underline{M}} \underline{\underline{I}} \underline{\underline{P}} \underline{\underline{V}} \underline{\underline{Q}} \underline{\underline{l}} \underline{\underline{A}} \underline{\underline{K}} L A E Q F F V S L G L Q P M T K E F W S N S L F E K P K D$. RKVV C

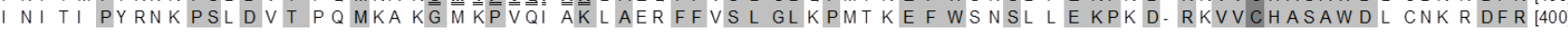

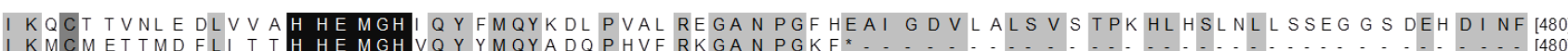

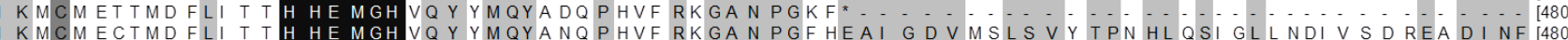

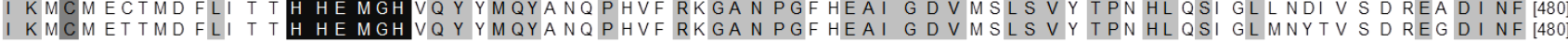
LMKMALDKI A FI PFS Y L V DQWRWR VFDGSI T KENY NQEWWSLRLKYQGLCPPVPRT QGDFDPGAKFHI PSS V P Y R Y FVS [560 LLQMA LKKI A FLPF G I L DKWRWE VYSGEIEFEEWNRRWWEMRFKYQG VCPPIRRTEIDFDPGAKFHVPADTPYIR FIS LLQMA LKKI A FLPY GY I L DKWRWG VY SGEVELDEWNT KW WEM FI I QF QFHEALCQA A G HT GPL HKC DI YQSKEAGQR LATA MKLGFSRP WPEAMQL I T GQP NMSASAMLSYFKPLLDWLRTE[640] FI QF QFHEA LCRVSG FQGPL HKC DI YNSKEA GKLISGMMQMGSSRP WPEAFEKI T GSR KMNADSLLEYFKPLYEWLKEA 640

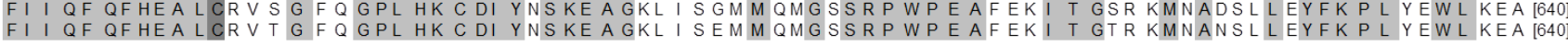
NELHGEKLGWPQYNWT PN SAR SE GPLDSGR VSFLGLDLDAQQARVGQWLLLFL GI ALLVATLGLSQRLFS।RHRSLHRH T20 NK $\ldots$ N EVI GWETF D $\mathrm{T}$ T V $\mathrm{C} P \ldots \ldots \ldots$ NK. N NTI GWNTI DPT VCP.

SHGPQFGSEVELRHS [735] $\left.\begin{array}{lll}\cdots & \cdots & \cdots\end{array}\right]$ 